Prepared in cooperation with the

KANSAS DEPARTMENT OF HEALTH AND ENVIRONMENT

\title{
Hydrologic and Water-Quality Conditions in the Kansas River, Northeast Kansas, November 2001- August 2002, and Simulation of Ammonia Assimilative Capacity and Bacteria Transport During Low Flow
}

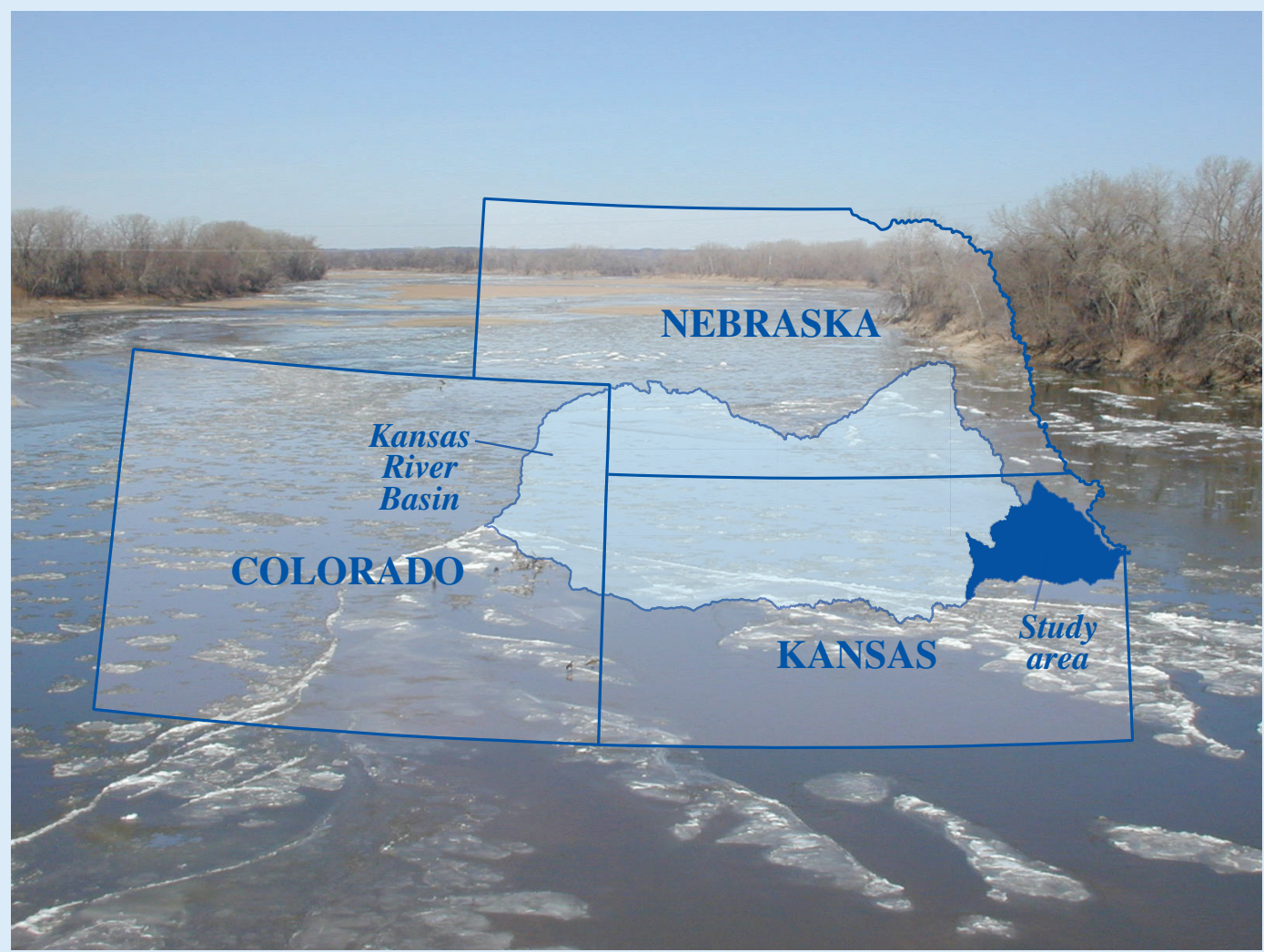

Scientific Investigations Report 2005-5188 


\section{Hydrologic and Water-Quality Conditions in the Kansas River, Northeast Kansas, November 2001-August 2002, and Simulation of Ammonia Assimilative Capacity and Bacteria Transport During Low Flow}

By Patrick P. Rasmussen and Victoria G. Christensen

Prepared in cooperation with the

KANSAS DEPARTMENT OF HEALTH AND ENVIRONMENT

Scientific Investigations Report 2005-5188 


\title{
U.S. Department of the Interior Gale A. Norton, Secretary
}

\author{
U.S. Geological Survey \\ P. Patrick Leahy, Acting Director
}

\section{U.S. Geological Survey, Reston, Virginia: 2005}

For sale by U.S. Geological Survey, Information Services

Box 25286, Denver Federal Center

Denver, CO 80225

For more information about the USGS and its products:

Telephone: 1-888-ASK-USGS

World Wide Web: http://www.usgs.gov/

Any use of trade, product, or firm names in this publication is for descriptive purposes only and does not imply endorsement by the U.S. Government.

Although this report is in the public domain, permission must be secured from the individual copyright owners to reproduce any copyrighted materials contained within this report.

Suggested citation:

Rasmussen, P.P., and Christensen, V.G., 2005, Hydrologic and water-quality conditions in the Kansas River, northeast Kansas, November 2001-August 2002, and simulation of ammonia assimilative capacity and bacteria transport during low flow: U.S. Geological Survey Scientific Investigations Report 2005-5188, 111 p. 


\section{Contents}

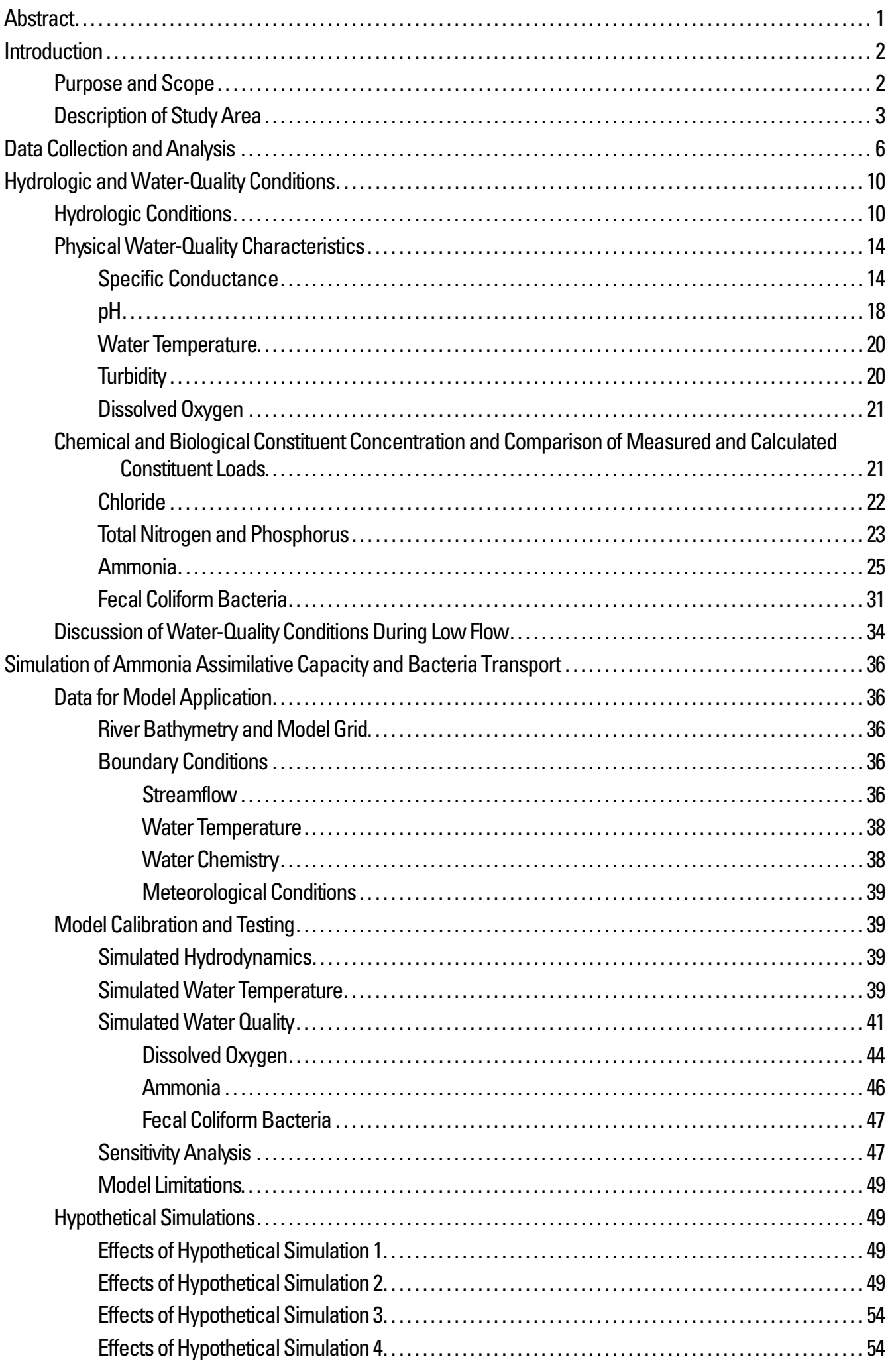




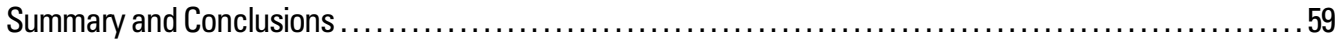

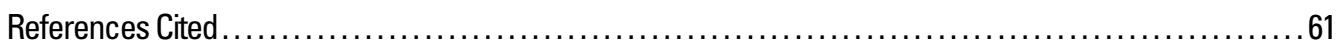

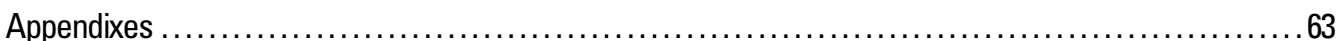

1. Water-quality results from samples collected from Kansas River, northeast Kansas, selected tributaries, and selected wastewater-treatment facility effluent for synoptic surveys I, II, and III, November 2001 through August 2002.

2. List of wastewater-treatment facilities that discharge effluent to the Kansas River and its tributary streams in northeast Kansas and design limits............................ 102

3. Hypothetical simulations using 30-day, 10-year, low-flow conditions ..................... 104

\section{Figures}

1-3. Maps showing:

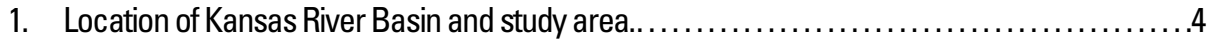

2. Location of streamflow-gaging stations, continuous water-quality monitoring sites,

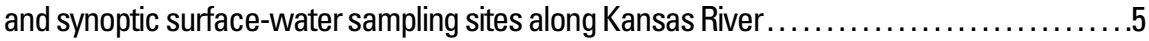

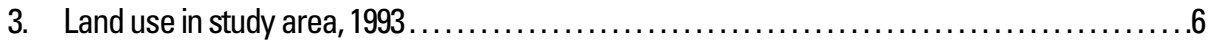

4. Graph showing accumulated monthly precipitation from November 2001 through August 2002 and 30-year mean monthly precipitation measured at Topeka Philip Billard Municipal Airport and Kansas City International Airport.

5. Hydrograph showing long-term, average monthly streamflow, 1971-2000, and observed average monthly streamflow, November 2001 through August 2002, for Kansas River at Topeka and DeSoto

6. Hydrographs showing daily mean and hourly streamflow in Kansas River at Topeka, Lecompton, and DeSoto, November 2001 through August 2002

7. Graph showing streamflow duration curves, 30-day, 10-year low flows, and mean daily streamflow for 1971 through 2000 and for synoptic surveys from November 2001 through

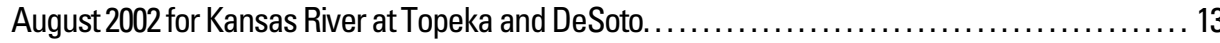

8. Photograph of Bowersock Dam on Kansas River at Lawrence, Kansas..................... 14

9. Map showing location of U. S. Geological Survey streamflow-gaging stations, continuous water-quality monitors, and wastewater discharge sites in study area. 15

10-23. Graphs showing:

10. Comparison of measured streamflow in Kansas River with cumulative streamflow calculated from measured inputs and withdrawals during synoptic surveys I, II, and III, November 2001 through August 2002 16

11. Mean daily values for streamflow, specific conductance, $\mathrm{pH}$, water temperature, turbidity, and dissolved oxygen in Kansas River at Wamego, Topeka, and DeSoto, November 2001August 2002 17

12. Duration curve for $\mathrm{pH}$ in Kansas River at Topeka, October 2000 through September 2003, and

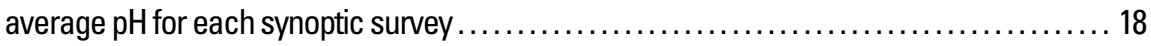

13. Acute and chronic aquatic-life criteria for total ammonia as nitrogen................. 19

14. Duration curve for water temperature in Kansas River at Topeka, October 2000 through September 2003, and mean daily water temperature for each synoptic survey. .... 20

15. Duration curve for dissolved-oxygen concentration in Kansas River at Topeka, October 2000 through September 2003, and average dissolved-oxygen concentration for each synoptic survey.

16. Chloride concentrations in samples collected from main-stem Kansas River, tributaries, and wastewater-treatment facility effluent for synoptic survey I and synoptic survey II. 
17. Calculated measured and cumulative chloride loads in Kansas River during synoptic

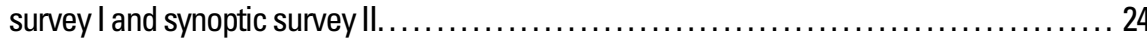

18. Concentrations of total nitrogen in samples collected from main-stem

Kansas River, tributaries, and wastewater-treatment facility effluent for synoptic

survey I, synoptic survey II, and synoptic survey III.......................... 26

19. Concentrations of total phosphorus in samples collected from main-stem

Kansas River, tributaries, and wastewater-treatment facility effluent for synoptic

survey I, synoptic survey II, and synoptic survey III........................... 27

20. Concentrations of ammonia in samples collected from main-stem Kansas River, tributaries, and wastewater-treatment facility effluent for synoptic survey l, synoptic

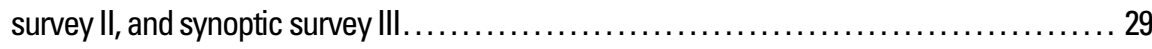

21. Calculated measured and cumulative ammonia loads in Kansas River

during synoptic survey I, synoptic survey II, and synoptic survey III ................... 32

22. Fecal coliform bacteria densities in samples collected from main-stem

Kansas River, tributaries, and wastewater-treatment facility effluent for synoptic

survey I, synoptic survey II, and synoptic survey III.............................. 33

23. Calculated measured and cumulative loads of fecal coliform bacteria in

Kansas River for synoptic survey I, synoptic survey II, and synoptic survey III ....

24. Schematic diagram showing plan view of top layer of computational grid for Kansas River

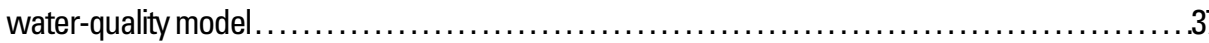

25. Schematic diagram showing computational layers at model segment 14 for Kansas River

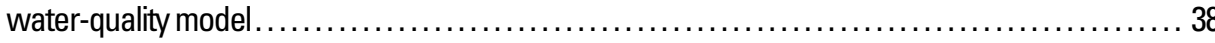

26-36. Graphs showing:

26. Measured and simulated hourly streamflows in Kansas River at Lecompton

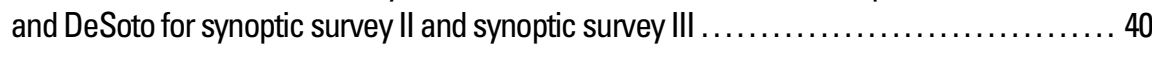

27. Measured and simulated hourly water temperatures in Kansas River at Lecompton and DeSoto for synoptic survey II and synoptic survey III ................ 41

28. Measured and simulated hourly dissolved-oxygen concentrations in Kansas River at Lecompton and DeSoto for synoptic survey II and synoptic survey III . ................ 45

29. Measured and simulated ammonia concentrations in Kansas River from Topeka to confluence with Missouri River for synoptic survey II and synoptic survey III

30. Measured and simulated fecal coliform bacteria densities in Kansas River at Lecompton and DeSoto for synoptic survey II and synoptic survey III . ....

31. Simulated ammonia and dissolved-oxygen concentrations in Kansas River from Topeka to Kansas City during winter and summer low streamflow conditions for calibrated model and hypothetical simulations 1 and 2 .

32. Simulated ammonia and dissolved-oxygen concentrations in Kansas River from Topeka to Kansas City during winter and summer low streamflow conditions for calibrated model and hypothetical simulations 1 and 3 . ...

33. Simulated ammonia and dissolved-oxygen concentrations in Kansas River from Topeka to Kansas City during winter and summer low streamflow conditions for calibrated model and hypothetical simulations 1 and 4 . ...

34. Simulated ammonia and dissolved-oxygen concentrations in Kansas River from Topeka to Kansas City during winter and summer 30-day, 10-year, low-flow conditions for 30010 calibrated model and hypothetical simulations 1 and 2 ....

35. Simulated ammonia and dissolved-oxygen concentrations in Kansas River from Topeka to Kansas City during winter and summer 30-day, 10-year, low-flow conditions for 30010 calibrated model and hypothetical simulations 1 and 3 .... 
36. Simulated ammonia and dissolved-oxygen concentrations in Kansas River from Topeka to Kansas City during winter and summer 30-day, 10-year, low-flow conditions for 30010 calibrated model and hypothetical simulations 1 and 4

\section{Tables}

1. Basin characteristics of the Kansas River and major tributaries in northeast Kansas ..............3

2. Population of counties adjacent to the Kansas River in northeast Kansas in 2000 and projected for 2030

3. Data-collection sites in the Kansas River Basin, northeast Kansas, sampled during synoptic surveys, November 2001-August 2002.

4. Calculated 30-day, 10-year low flows for the Kansas River at selected U.S. Geological Survey streamflow-gaging stations in northeast Kansas, 1971-2000 and 1968-97.

5. Statistical summary of chloride concentrations in samples collected from the Kansas River, northeast Kansas, its tributaries, and selected wastewater-treatment facility effluent for synoptic surveys I and II, November 27-29, 2001, and February 25-March 1, 2002 _... 22

6. Statistical summary of total nitrogen concentrations in samples collected from the Kansas River, northeast Kansas, its tributaries, and selected wastewater-treatment facility effluent for synoptic surveys I, II, and III, November 2001-August 2002.

7. Statistical summary of total phosphorus concentrations in samples collected from the Kansas River, northeast Kansas, its tributaries, and selected wastewater-treatment facility effluent for synoptic surveys I, II, and III, November 2001- August 2002.

8. Statistical summary of ammonia concentrations in samples collected from the Kansas River, northeast Kansas, its tributaries, and selected wastewater-treatment facility effluent for synoptic surveys I, II, and III, November 2001- August 2002.

9. Estimated rates of ammonia decay in the Kansas River, northeast Kansas, during winter, February 25-March 1, 2002, and summer, July 22-August 8, 2002.

10. Statistical summary of fecal coliform densities in samples from the Kansas River, northeast Kansas, its tributaries, and selected wastewater-treatment facility effluent for synoptic surveys I, II, and III, November 2001-August 2002.

11. Model parameters and calculated values specified as input for water-quality model of Kansas River in northeast Kansas ....

12. Boundary conditions used in CE-QUAL-W2 model for various hypothetical simulations describing possible effects on water quality in Kansas River in northeast Kansas during winter and summer. 


\section{Conversion Factors, Water-Quality Abbreviations, and Datum}

\begin{tabular}{lll}
\multicolumn{3}{l}{ Conversion Factors } \\
\hline Multiply & By & To obtain \\
\hline cubic foot per second $\left(\mathrm{ft}^{3} / \mathrm{s}\right)$ & 0.02832 & cubic meter per second $\left(\mathrm{m}^{3} / \mathrm{s}\right)$ \\
foot $(\mathrm{ft})$ & 0.3048 & meter $(\mathrm{m})$ \\
foot per mile $(\mathrm{ft} / \mathrm{mi})$ & 0.1894 & meter per kilometer $(\mathrm{m} / \mathrm{km})$ \\
gram per cubic meter $\left(\mathrm{g} / \mathrm{m}^{3}\right)$ & 0.00006243 & pound per cubic foot $\left(\mathrm{lb} / \mathrm{ft}^{3}\right)$ \\
inch $($ in. $)$ & 2.54 & centimeter $(\mathrm{cm})$ \\
kilogram per day $(\mathrm{kg} / \mathrm{d})$ & 2.205 & pound per day $(\mathrm{lb} / \mathrm{d})$ \\
meter $(\mathrm{m})$ & 3.281 & foot $(\mathrm{ft})$ \\
meter per day $(\mathrm{m} / \mathrm{d})$ & 3.281 & foot per day $(\mathrm{ft} / \mathrm{d})$ \\
micrometer $(\mu \mathrm{m})$ & 0.00003937 & inch $(i n)$. \\
mile $(m i)$ & 1.609 & kilometer $(\mathrm{km})$ \\
milligram per liter $(\mathrm{mg} / \mathrm{L})$ & 1.0 & part per million $(\mathrm{ppm})$ \\
million gallons per day $(\mathrm{Mgal} / \mathrm{d})$ & 0.04381 & cubic meter per second $\left(\mathrm{m}^{3} / \mathrm{s}\right)$ \\
square mile $\left(\mathrm{mi}{ }^{2}\right)$ & 2.590 & square kilometer $\left(\mathrm{km}{ }^{2}\right)$ \\
watt per square meter $\left(\mathrm{W} / \mathrm{m}^{2}\right)$ & 0.859845 & kilocalorie $(\mathrm{kcal})$ \\
\hline
\end{tabular}

Temperature in degrees Celsius $\left({ }^{\circ} \mathrm{C}\right)$ may be converted to degrees Fahrenheit $\left({ }^{\circ} \mathrm{F}\right)$ as follows:

${ }^{\circ} \mathrm{F}=\left(1.8 \mathrm{x}^{\circ} \mathrm{C}\right)+32$.

Temperature in degrees Fahrenheit $\left({ }^{\circ} \mathrm{F}\right)$ may be converted to degrees Celsius $\left({ }^{\circ} \mathrm{C}\right)$ as follows:

${ }^{\circ} \mathrm{C}=\left({ }^{\circ} \mathrm{F}-32\right) / 1.8$.

\section{Water-Quality Abbreviations}

$\mathrm{col} / 100 \mathrm{~mL}$-colonies per 100 milliliters of water

$\mu \mathrm{S} / \mathrm{cm}$ - microsiemens per centimeter at $25{ }^{\circ} \mathrm{C}$

$\mathrm{mg} / \mathrm{L}$-milligrams per liter

Datum

Horizontal coordinate information is referenced to the North American Datum of 1983 (NAD 83). 


\title{
Hydrologic and Water-Quality Conditions in the Kansas River, Northeast Kansas, November 2001-August 2002, and Simulation of Ammonia Assimilative Capacity and Bacteria Transport During Low Flow
}

\author{
By Patrick P. Rasmussen and Victoria G. Christensen
}

\section{Abstract}

Large concentrations of ammonia and densities of bacteria have been detected in reaches of the Kansas River in northeast Kansas during low streamflow conditions, prompting the Kansas Department of Health and Environment (KDHE) to list these reaches as water-quality limited with respect to ammonia and fecal coliform bacteria. Sources for ammonia and bacteria in the watershed consist of wastewater-treatment facilities (WWTFs) and agricultural and urban runoff. The U.S. Geological Survey (USGS), in cooperation with KDHE, conducted an investigation of the Kansas River to characterize hydrologic and water-quality conditions and to simulate ammonia assimilative capacity and bacteria transport during low streamflow. This report characterizes the water-quality conditions, documents the calibration of a two-dimensional water-quality model, and presents results of hypothetical simulations of existing and future WWTFs discharging to the Kansas River during low streamflow.

Water samples were collected during low streamflow conditions at 50 sampling sites along and near the Kansas River between Wamego and Kansas City, Kansas, during three synoptic surveys conducted between November 2001 and August 2002. The analytical results from these samples indicated that ammonia and other nutrient concentrations and fecal coliform bacteria densities increased in the Kansas River from Wamego to Kansas City. Point sources were the primary contributors of ammonia and fecal coliform bacteria during low-flow conditions. Generally, ammonia concentrations in the Kansas River were largest at sampling sites just downstream from WWTFs. Overall, ammonia concentrations in the Kansas River, tributaries, and WWTF effluent were larger in the winter than during the summer. None of the main-stem sample concentrations exceeded the State of Kansas pH- and temperature-dependent chronic aquatic-life criteria for ammonia during the sampling periods. Other nutrients, such as total nitrogen and total phosphorus, indicated a similar, but less variable, spatial pattern along the main stem of the Kansas River, with concentrations increasing slightly downstream from major WWTFs. The temporal variance defined by the results of synoptic survey III
(July 22-August 8, 2002) indicated that ammonia concentrations in the Kansas River sometimes varied daily by as much as 155 percent at a single site.

Samples analyzed for densities of fecal coliform bacteria illustrated a seasonal, spatial, and temporal pattern slightly different from that of nutrients. Overall, the bacteria densities measured during the summer were larger than the densities measured in the winter. The only fecal coliform bacteria density to exceed the former State water-quality, single-sample criteria of $2,000 \mathrm{col} / 100 \mathrm{~mL}$ (colonies per 100 milliliters of water) was measured at 4,000 col/100 mL during synoptic III (summer 2002) on the main stem of the Kansas River at Kansas City. Temporal variability measured during synoptic survey III indicated up to a 263-percent difference in bacteria density over a 12-day period.

Instantaneous loads of ammonia and bacteria were computed to determine primary inputs to the Kansas River and ammonia and bacteria decay rates in the river. The Oakland WWTF in Topeka was the largest contributor of both ammonia and bacteria on the basis of samples collected during the three synoptic surveys, except for fecal coliform bacteria collected during synoptic survey III when the DeSoto WWTF was discharging the largest concentration of bacteria. The ammonia assimilative process was about twice as effective during the summer synoptic survey than it was during the winter survey. Decay of fecal coliform bacteria density was less evident and appeared to have little seasonal effect on the basis of data collected for this report. The summer low-streamflow water-quality conditions were suitable for nitrification, algae that consume ammonia, and consequently, decaying organic matter that consume oxygen. The consumption of dissolved oxygen due to nitrification and decaying algae contributed to three measurements of dissolved oxygen that were less than the State of Kansas aquatic-life-support use criteria of 5.0 milligrams per liter.

CE-QUAL-W2, a two-dimensional, hydrodynamic and water-quality model, was used to simulate ammonia and bacteria transport in the Kansas River from Topeka to Kansas City. The model was calibrated and verified using data from the three synoptic surveys. The calibrated model successfully simulated the hydrodynamics, water temperature, dissolved oxygen, 


\section{Hydrologic and Water-Quality Conditions in the Kansas River, Northeast Kansas, November 2001-August 2002}

ammonia, and fecal coliform bacteria in the Kansas River. Simulated in-stream ammonia concentrations were compared to measured concentrations upstream to downstream along the Kansas River. The simulated in-stream ammonia concentrations mostly overestimated the measured values for both winter and summer, with a few exceptions. Comparisons between measured and simulated in-stream ammonia concentrations indicated ammonia assimilation was simulated more accurately in the summer than during the winter.

Four hypothetical simulations of varied effluent discharges from existing WWTFs and addition of a proposed WWTF near DeSoto were simulated to better understand future water-quality conditions in the Kansas River. Results indicated that ammonia and dissolved-oxygen concentrations in the Kansas River will decrease from the conditions observed during synoptic surveys II (February 25 through March 1, 2002) and III (July 22 through August 8, 2002) except near the proposed WWTF where concentrations of ammonia would be near or exceed criteria for waterborne species. Effects of the proposed WWTF on dissolved oxygen would result in concentrations less than the State of Kansas aquatic-life-support use criteria of 5.0 milligrams per liter for 1 to 2 miles downstream from either of the proposed sites.

\section{Introduction}

In Kansas, elevated concentrations of nutrients and densities of bacteria are two of the most common contaminants responsible for causing a stream segment to be designated as water-quality impaired (Kansas Department of Health and Environment, 2004). In response to the Federal Clean Water Act of 1972, the Kansas Department of Health and Environment (KDHE) has listed segments of the Kansas River as water-quality impaired with respect to ammonia and fecal coliform bacteria. The term "water-quality limited" defines stream segments that do not meet established water-quality criteria and, therefore, are limited to a lesser designated use. Once a stream has been designated as water-quality limited and appears on the water-quality limited (303d) list, the Federal Clean Water Act requires that States establish total maximum daily loads

(TMDLs) to meet those water-quality criteria. A TMDL is a calculation of the maximum amount of a contaminant that a waterbody can receive and still meet water-quality standards.

Point and nonpoint sources of dissolved solids, nutrients, and bacteria may cause water to be unsuitable for growth, reproduction, and diversity of aquatic organisms; pose potential public health problems in processed drinking water; and reduce the recreational desirability of the stream (U.S. Environmental Protection Agency, 1986). Treatment facility upgrades and bestmanagement practices within the watershed are possible solutions for improving water quality.

The effects of rapid population growth and urban development on water quality are a concern along the Kansas River between Topeka and Kansas City. Wastewater-treatment facilities (WWTFs) discharging large concentrations of ammonia and densities of bacteria are of particular concern during low streamflow conditions when the quantity of water in the stream does not sufficiently dilute the ammonia. Large ammonia concentrations can cause excessive algal production and in-stream nitrification during the summer, which can result in small dissolved-oxygen concentrations downstream from WWTFs and nonpoint sources of contaminants. Small dissolved-oxygen concentrations are a concern because dissolved oxygen is vitally important for the survival of fish and other aquatic species. Large densities of fecal coliform bacteria indicate elevated risks to people using the stream because contact with the water could increase the risk of contracting human diseases ranging from mild diarrhea to respiratory disease, septicemia, meningitis, and polio (Dufour, 1977; Pepper and others, 1996). As urban growth continues along the Kansas River, capacities of existing WWTFs will increase, and new WWTFs will discharge to the river. The assimilative capacity for ammonia and bacteria in the Kansas River need to be assessed so that river resources can be better managed to incorporate future population growth without exceeding water-quality criteria.

In July 2000, the U.S. Geological Survey (USGS), in cooperation with KDHE and support from the U.S. Environmental Protection Agency, began an investigation of that part of the Kansas River Basin in northeast Kansas to characterize and simulate water-quality conditions in the river during low streamflow conditions. Three synoptic streamflow and waterquality surveys were conducted from November 2001 through August 2002. A total of 147 samples were collected at 50 sites within and along the Kansas River between Wamego and Kansas City, Kansas. Continuous water-quality monitors also were installed in the Kansas River at Wamego, Topeka, and DeSoto. The data from the samples collected and the hourly measurements from the water-quality monitors were used to calibrate and verify a two-dimensional water-quality model of the Kansas River from Topeka to Kansas City, Kansas.

\section{Purpose and Scope}

The primary purpose of this report is to describe hydrologic and water-quality conditions and the assessment of the assimilative capacity of ammonia and bacteria transport in the Kansas River during low streamflow conditions. For this report, low-flow conditions in the Kansas River were defined as streamflows less than $2,500 \mathrm{ft}^{3} / \mathrm{s}$.

The specific objectives of the report are to (1) characterize ambient hydrologic and water-quality conditions during the study period from November 2001 to August 2002, (2) document calibration of the CE-QUAL-W2 water-quality model, and (3) present the results of model simulations for selected hypothetical situations describing the effects of an additional WWTF and changes in WWTF effluent discharges on water quality of the Kansas River during low streamflow conditions. The results presented in this report provide KDHE with information necessary for making decisions regarding effects from existing and proposed WWTFs on water-quality conditions in the Kansas River. 


\section{Description of Study Area}

The Kansas River is formed by the confluence of the Smoky Hill and Republican Rivers near Junction City, Kansas (fig. 1). From there, the river flows $170 \mathrm{mi}$ to Kansas City where it discharges to the Missouri River. The entire drainage area for the Kansas River Basin at Kansas City is $60,097 \mathrm{mi}^{2}$ (table 1) encompassing the northern half of Kansas and extending into Nebraska and Colorado. Streamflow in the Kansas River is regulated by seven large reservoirs-Kanopolis, Wilson, Waconda, Milford, Tuttle Creek, Perry, and Clinton Lakes, operated by the U.S. Army Corps of Engineers. For this study, a stream was considered regulated if 20 percent or more of its drainage area is upstream from an impoundment. Low streamflow in the Kansas River downstream from Lawrence also is affected by a low-water dam operated by Bowersock Mills and Power Company (Lawrence, Kansas).

There are five major tributaries of the Kansas River that are gaged by USGS (Smoky Hill, Republican, Big Blue, Delaware, and Wakarusa Rivers), and each of their corresponding drainage areas are at least 71 percent regulated (table 1). About 85 percent of the entire Kansas River Basin is regulated. Seven nonregulated tributaries, with drainage areas ranging from 70 to $533 \mathrm{mi}^{2}$ (Clarks, Vermillion, Mill, Cross, Soldier, Shunganunga, and Stranger Creeks, see fig. 2 for location), have a cumulative total drainage area of $2,296 \mathrm{mi}^{2}$. The remaining drainage area consist of several smaller unregulated tributaries (drainage areas less than $70 \mathrm{mi}^{2}$ ) totaling about 1,600 $\mathrm{mi}^{2}$.
Land use throughout the study area $\left(5,555 \mathrm{mi}^{2}\right)$ is primarily agricultural (cropland and grassland) with some urban areas including Junction City, Manhattan, Topeka, Lawrence, and Kansas City, Kansas (fig. 3). Counties adjacent to the Kansas River support a growing population of nearly 800,000 people (Policy Research Institute, 2002; table 2). WWTFs in the counties along the main stem of the Kansas River discharge directly into the river or into a tributary immediately upstream from the Kansas River (M.E. Gerard, KDHE, written commun., 2004).

The climate of the Kansas River Basin is affected by the movement of frontal air masses over the open, inland plains, and seasonal precipitation extremes are common. About 65 percent of the mean annual precipitation falls from April through September. During the summer months, the weather is dominated by warm, moist air from the Gulf of Mexico or by hot, dry air from the Southwest. Summer precipitation generally occurs as high-intensity thunderstorms. Generally, the climatic characteristics vary in an east-west direction, with little north-south variation. The general climate of the western part of the Kansas River Basin is semiarid with hot, dry summer months and cold, windy winter months. The general climate of the eastern part of the basin tends to be more humid, with sultry summer months and cold winter months.

Mean annual precipitation in the Kansas River Basin varies from about 16 in. in the extreme western part of the basin to about 42 in. in the east (Daly and others, 1997). Mean annual precipitation for the period 1971 through 2000 for the downstream part of the Kansas River Basin as measured by the National Weather Service at the Topeka Philip Billard

Table 1. Basin characteristics of the Kansas River and major tributaries in northeast Kansas.

$\left[\mathrm{mi}^{2}\right.$, square miles; --, not determined]

\begin{tabular}{|c|c|c|c|}
\hline $\begin{array}{l}\text { Stream name } \\
\quad \text { (fig. 2) }\end{array}$ & $\begin{array}{l}\text { Miles upstream from confluence } \\
\text { with Missouri River }\end{array}$ & $\begin{array}{l}\text { Total drainage area } \\
\qquad\left(\mathrm{mi}^{2}\right)\end{array}$ & $\begin{array}{c}\text { Total regulated drainage area }{ }^{1}\left(\mathrm{mi}^{2}\right) \\
\text { [percentage of drainage area that is regulated] }\end{array}$ \\
\hline Smoky Hill River & 170.4 & 19,950 & $14,850[74.4]$ \\
\hline Clarks Creek & 163.4 & 280 & -- \\
\hline Big Blue River & 147.5 & 9,681 & $9,628[99.4]$ \\
\hline Vermillion Creek & 121.4 & 521 & -- \\
\hline Mill Creek & 104.1 & 408 & -- \\
\hline Cross Creek & 102.5 & 180 & -- \\
\hline Soldier Creek & 80.5 & 304 & -- \\
\hline Shunganunga Creek & 75.7 & 70 & -- \\
\hline Delaware River & 64.7 & 1,144 & $1,117[97.6]$ \\
\hline Small tributaries & $\begin{array}{l}\text { Various locations along the } \\
\text { Kansas River }\end{array}$ & 1,598 & -- \\
\hline Kansas River & 0 & 60,097 & $50,842[84.6]$ \\
\hline
\end{tabular}

\footnotetext{
${ }^{1}$ For this study, a stream was considered regulated if 20 percent or more of its drainage area is upstream from an impoundment.
} 


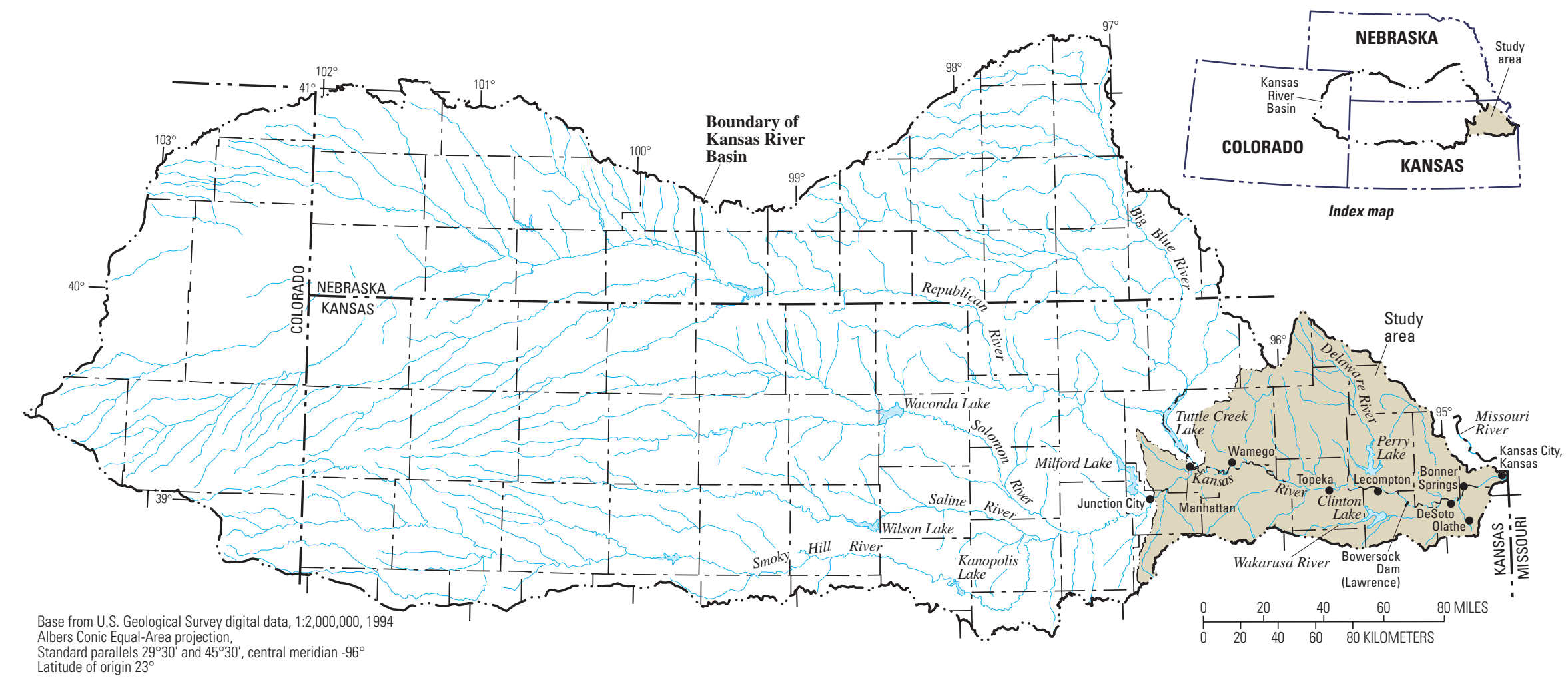

Horizontal coordinate information is referenced to the North American

Datum of 1983 (NAD 83)

Figure 1. Location of Kansas River Basin and study area. 


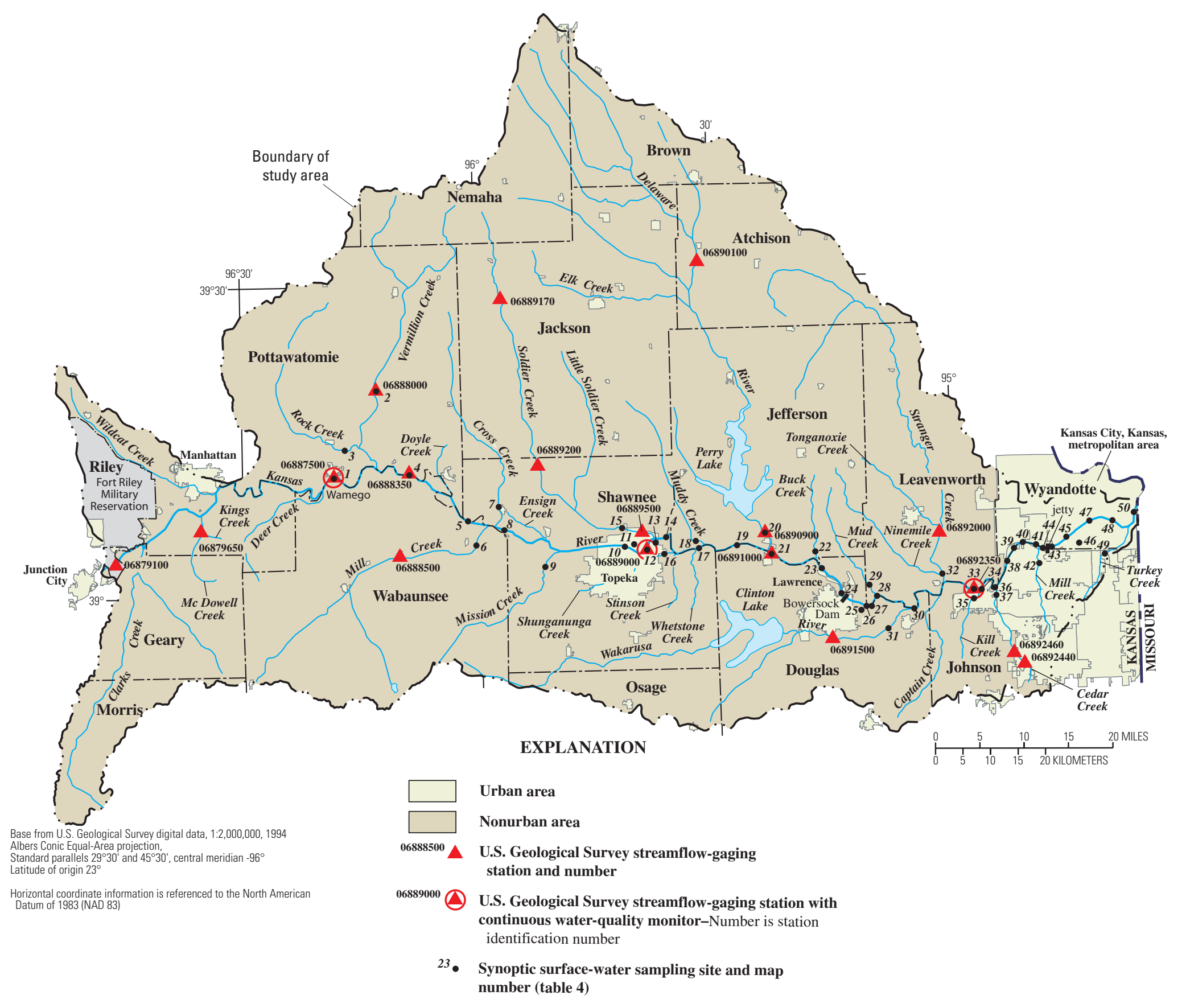

Figure 2. Location of streamflow-gaging stations, continuous water-quality monitoring sites, and synoptic surface-water sampling sites along Kansas River. 


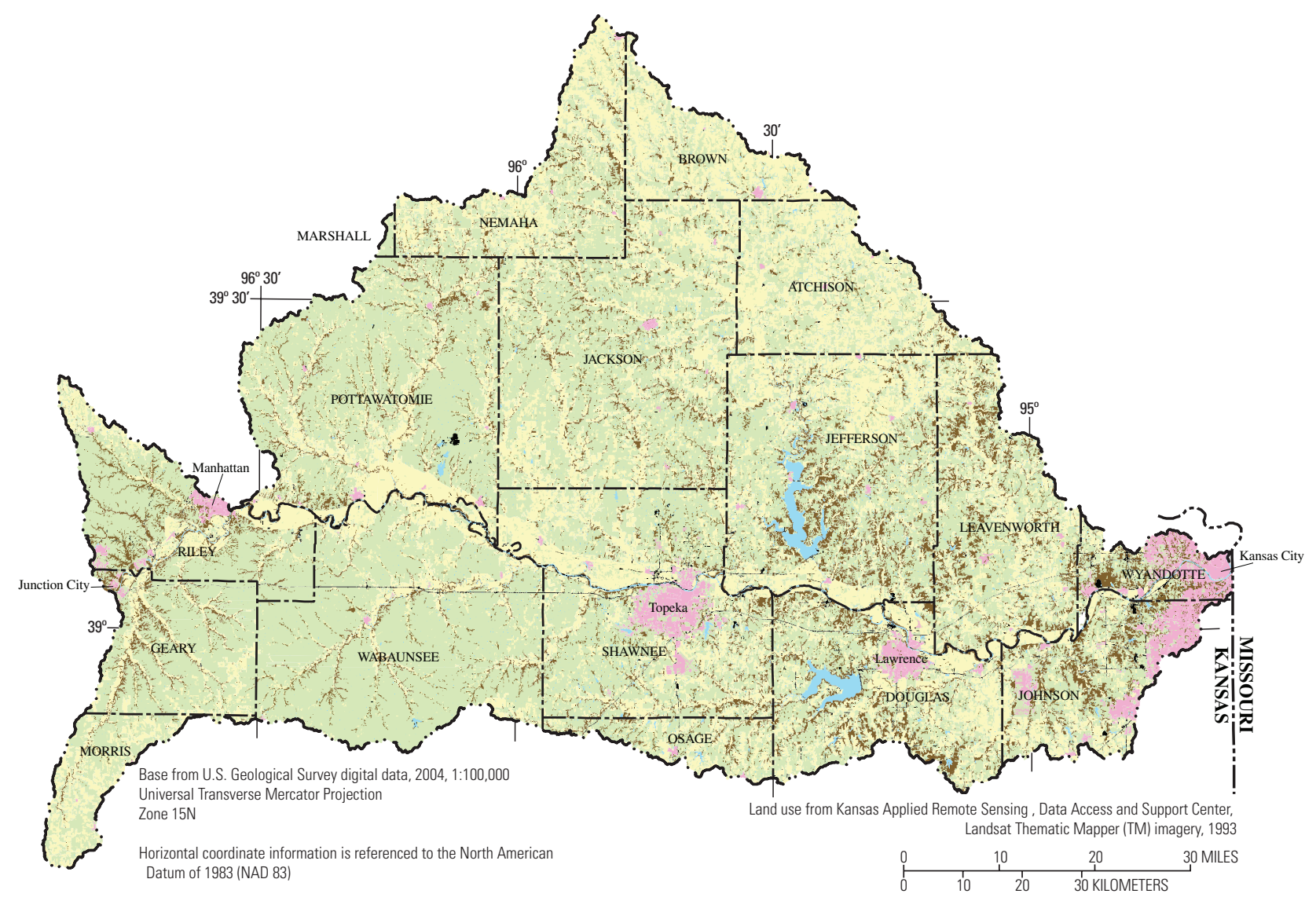

\section{EXPLANATION}

Land use

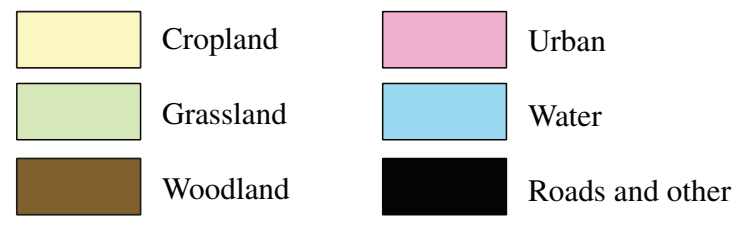

_ $\cdots \_$Boundary of lower Kansas River Basin

Figure 3. Land use in study area, 1993.

Municipal and Kansas City International Airports (fig. 4) was 36 and 38 in., respectively (National Oceanic and Atmospheric Administration, 2002 and 2003).

Monthly precipitation during the 10-month study period generally was less than normal. The monthly totals for the three synoptic surveys (November 2001, February 2002, and July 2002) ranged between 19 and 71 percent less than normal. These dry conditions led to low streamflow conditions that were favorable for collecting samples for this type of study. A trace of precipitation occurred during synoptic surveys I

(November 27-29, 2001) and II (February 25-March 1, 2002). A widespread storm of about 0.75 in. of rain occurred during synoptic survey III (July 22-August 8, 2002).

\section{Data Collection and Analysis}

Water-quantity and -quality measurements and samples were collected during three synoptic surveys of the Kansas River. Fifty sampling sites were established within the study area; 24 along the Kansas River, 18 on tributaries to the Kansas River, and 8 at the effluent of WWTFs (fig. 2, table 3). Onehundred and forty-seven water-quality samples were collected during the synoptic surveys; 24 samples were collected from 24 sites during November 27-29, 2001, for synoptic survey I; 49 samples were collected from 49 sites during the period February 25 through March 1, 2002, for synoptic survey II; and 74 samples were collected from 50 sites during July 22 through August 8, 2002, for synoptic survey III (table 3). Streamflow 
Table 2. Population of counties adjacent to the Kansas River in northeast Kansas in 2000 and projected for 2030 (data from Policy Research Institute, 2002).

\begin{tabular}{lrrc}
\hline \multicolumn{1}{c}{$\begin{array}{c}\text { County } \\
\text { (fig. 3) }\end{array}$} & 2000 population & $\begin{array}{c}\text { 2030 projected } \\
\text { population }\end{array}$ & $\begin{array}{c}\text { Percentage } \\
\text { change from } \\
\text { 2000 to 2030 }\end{array}$ \\
\hline Douglas & 95,849 & 104,199 & 8.7 \\
Geary & 33,258 & 40,322 & 21.2 \\
Jefferson & 16,746 & 17,996 & 7.5 \\
Johnson & 465,124 & 655,447 & 40.9 \\
Leavenworth & 73,616 & 87,236 & 18.5 \\
& & & \\
Pottawatomie & 17,722 & 22,279 & 25.7 \\
Riley & 70,970 & 81,265 & 14.5 \\
Shawnee & 169,632 & 166,809 & -1.7 \\
Wabaunsee & 6,391 & 5,960 & -6.7 \\
Wyandotte & 160,461 & 160,026 & -.3 \\
\hline
\end{tabular}

and water-quality measurements were recorded at each sampling site during sample collection. Continuous water-quality measurements were collected throughout the study period at USGS streamflow-gaging stations at Wamego, Topeka, and DeSoto, Kansas (fig. 2).

Sample collection for each survey began at downstream sampling sites near Kansas City and progressed up the Kansas
River to sites near Wamego. Samples were collected in this manner to ensure that the most important segments (downstream main stem, tributaries, and WWTFs) near Kansas City were sampled before possible rain and runoff might disrupt the ideal low streamflow conditions.

Depending on streamflow conditions, samples were collected either manually using a dip sampling method or using isokinetic, depth-integrated sampling methods (Wilde and others, 1999). Samples for the analysis of bacteria were collected by dipping a sterile sampling bottle at the center of streamflow. Samples were analyzed for all or some of the following properties and constituents: water-quality properties (specific conductance, $\mathrm{pH}$, water temperature, turbidity, and dissolved oxygen), major ions, nutrients, suspended sediment, bacteria, 7-day biological oxygen demand (BOD), carbonaceous biochemical oxygen demand (CBOD), and biovolume and algal species.

The USGS National Water-Quality Laboratory in Lakewood, Colorado, provided the analytical services for most constituents, with the exception of BOD, CBOD, bacteria, and algal species. Water samples were analyzed for BOD and CBOD at the KDHE Environmental Laboratory, Topeka, Kansas, according to methods presented in Eaton and others (1995). Samples for bacteria were analyzed at the USGS office in Lawrence, Kansas, according to methods presented in Myers and Sylvester (1997). Samples for algal species were identified and enumerated by BSA Environmental Services Laboratory, Inc. (BSA),

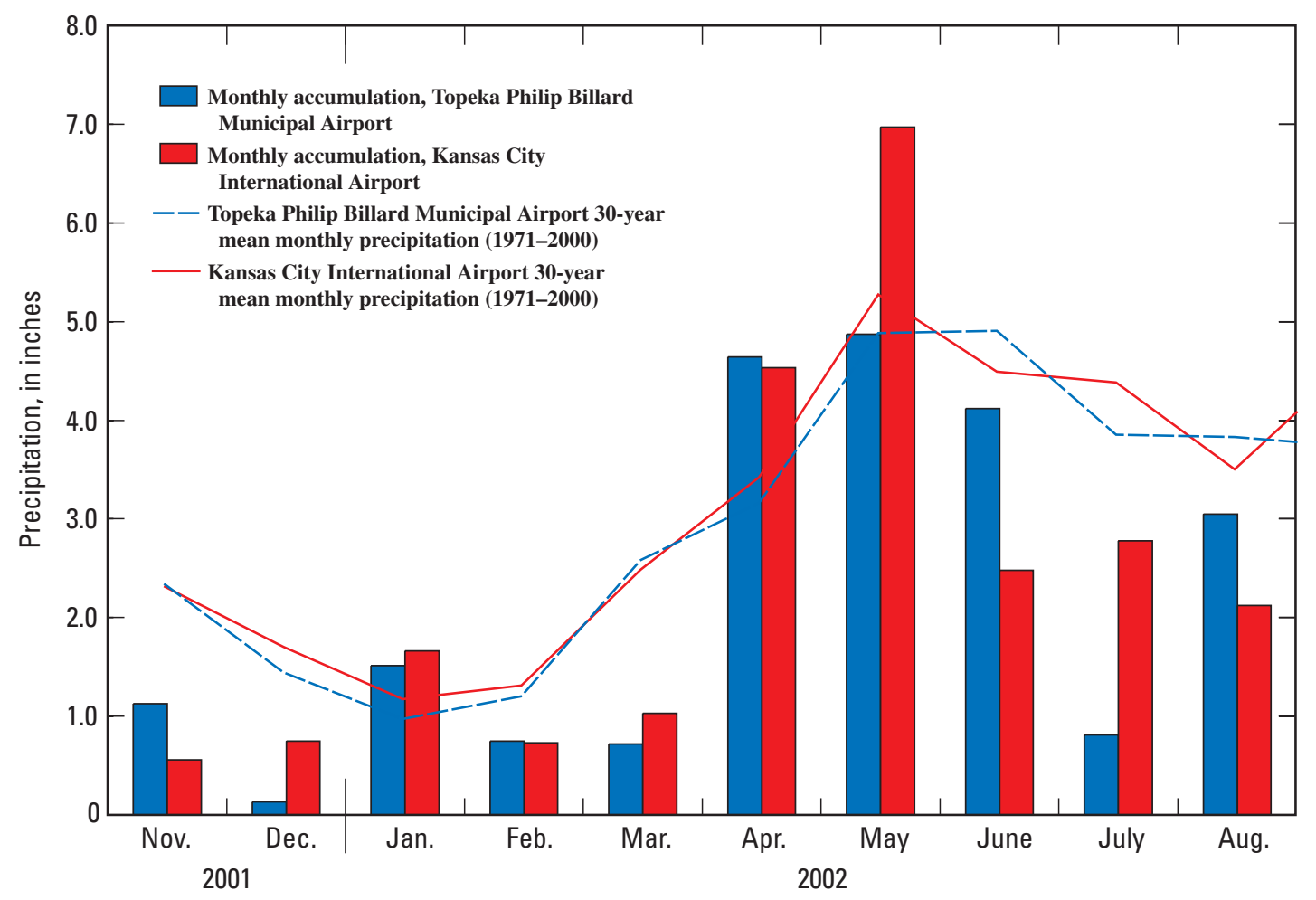

Figure 4. Accumulated monthly precipitation from November 2001 through August 2002 and 30-year mean monthly precipitation (1971-2000) measured at Topeka Philip Billard Municipal Airport and Kansas City International Airport (data from the National Oceanic and Atmospheric Administration, 2002, 2003). 
Table 3. Data-collection sites in the Kansas River Basin, northeast Kansas, sampled during synoptic surveys, November 2001August 2002.

[Shading indicates USGS streamflow-gaging station with continuous water-quality monitor; 1, sample collected; --, no sample collected]

\begin{tabular}{|c|c|c|c|c|c|c|}
\hline \multirow{2}{*}{$\begin{array}{l}\text { Map } \\
\text { number } \\
\text { (fig. 2) }\end{array}$} & \multirow{2}{*}{$\begin{array}{l}\text { U.S. Geological } \\
\text { Survey } \\
\text { identification } \\
\text { number }\end{array}$} & \multirow{2}{*}{$\begin{array}{l}\text { Miles } \\
\text { upstream } \\
\text { from the } \\
\text { Missouri } \\
\text { River }\end{array}$} & \multirow{2}{*}{ Site name } & \multicolumn{3}{|c|}{$\begin{array}{l}\text { Number of samples } \\
\text { collected for } \\
\text { synoptic surveys }\end{array}$} \\
\hline & & & & I & II & III \\
\hline 1 & 06887500 & 124.0 & Kansas River at Wamego & -- & -- & 1 \\
\hline 2 & 06888000 & 119.2 & Vermillion Creek near Wamego & -- & 1 & 1 \\
\hline 3 & 06888300 & 118.2 & Rock Creek near Louisville & -- & 1 & 1 \\
\hline 4 & 06888350 & 113.0 & Kansas River at Belvue & -- & 1 & 1 \\
\hline 5 & 06888400 & 103.7 & Kansas River near Maple Hill & -- & 1 & 1 \\
\hline 6 & 06888650 & 101.7 & Mill Creek near Maple Hill & -- & 1 & 1 \\
\hline 7 & 06888700 & 100.1 & Cross Creek near Rossville & -- & 1 & 1 \\
\hline 8 & 06888705 & 98.9 & Kansas River at Willard & -- & 1 & 1 \\
\hline 9 & 06888800 & 91.6 & Mission Creek near Valencia & -- & 1 & 1 \\
\hline 10 & 06888980 & 86.0 & Kansas River at Highway 75, Topeka & 1 & 1 & 1 \\
\hline 11 & 06888985 & 85.0 & North Topeka wastewater-treatment facility, Topeka & 1 & 1 & 1 \\
\hline 12 & 06889000 & 83.0 & Kansas River at Topeka & -- & 1 & 5 \\
\hline 13 & 06889002 & 81.7 & Topeka Oakland sewage treatment effluent & 1 & 1 & 1 \\
\hline 14 & 06889010 & 81.1 & Kansas River at Highway 4, Topeka & -- & 1 & 2 \\
\hline${ }^{2} 15$ & 06889504 & 80.5 & Soldier Creek, Meriden Road, near Topeka & 1 & 1 & 1 \\
\hline 16 & 06889700 & 76.0 & Shunganunga Creek at Rice Road, Topeka & 1 & 1 & 1 \\
\hline 17 & 06889750 & 73.7 & Kansas River near Grantville & -- & 1 & 1 \\
\hline 18 & 06889800 & 72.3 & Muddy Creek near Grantville & 1 & 1 & 1 \\
\hline 19 & 06889850 & 68.6 & Kansas River near Grover & -- & 1 & 2 \\
\hline 20 & 06890900 & 65.1 & Delaware River below Perry Dam & 1 & 1 & 1 \\
\hline${ }^{2} 21$ & 06891000 & 64.0 & Kansas River at Lecompton & 1 & 1 & 5 \\
\hline 22 & 06891060 & 58.6 & Buck Creek at Williamstown & -- & 1 & 1 \\
\hline 23 & 06891070 & 57.5 & Kansas River near Midland & -- & 1 & 1 \\
\hline 24 & 06891080 & 51.9 & Kansas River at Lawrence & -- & 1 & 1 \\
\hline 25 & 06891090 & 51.1 & Lawrence sewage treatment effluent & 1 & 1 & 1 \\
\hline 26 & 06891093 & 50.6 & Kansas River between Lawrence and Farmland effluent & -- & 1 & 2 \\
\hline 27 & 06891095 & 50.1 & Farmland nitrogen plant effluent, Lawrence & 1 & 1 & 1 \\
\hline 28 & 06891096 & 48.6 & Kansas River below Farmland effluent & -- & 1 & 1 \\
\hline 29 & 06891098 & 47.6 & Mud Creek near Lawrence & 1 & 1 & 1 \\
\hline 30 & 06891100 & 43.4 & Kansas River at Eudora & 1 & 1 & 1 \\
\hline
\end{tabular}


Table 3. Data-collection sites in the Kansas River Basin, northeast Kansas, sampled during synoptic surveys, November 2001August 2002.-Continued

[Shading indicates USGS streamflow-gaging station with continuous water-quality monitor; --, no sample collected]

\begin{tabular}{|c|c|c|c|c|c|c|}
\hline \multirow{2}{*}{$\begin{array}{l}\text { Map } \\
\text { number } \\
\text { (fig. 2) }\end{array}$} & \multirow{2}{*}{$\begin{array}{l}\text { U.S. Geological } \\
\text { Survey } \\
\text { identification } \\
\text { number }\end{array}$} & \multirow{2}{*}{$\begin{array}{l}\text { Miles } \\
\text { upstream } \\
\text { from the } \\
\text { Missouri } \\
\text { River }\end{array}$} & \multirow{2}{*}{ Site name } & \multicolumn{3}{|c|}{$\begin{array}{c}\text { Number of samples } \\
\text { collected for } \\
\text { synoptic surveys }\end{array}$} \\
\hline & & & & I & II & III \\
\hline${ }^{2} 31$ & 06891675 & 42.6 & Wakarusa River at 1900 Road near Eudora & 1 & 1 & 1 \\
\hline 32 & 06892200 & 35.4 & Stranger Creek above Linwood & 1 & 1 & 1 \\
\hline 33 & 06892350 & 31.7 & Kansas River at DeSoto & -- & 1 & 7 \\
\hline 34 & 06892358 & 31.0 & DeSoto sewage treatment effluent & -- & 1 & 1 \\
\hline 35 & 06892360 & 31.0 & Kill Creek at 83rd Street & 1 & 1 & 1 \\
\hline 36 & 06892380 & 30.8 & Kansas River near Cedar & -- & 1 & 2 \\
\hline 37 & 06892490 & 26.7 & Cedar Creek near Cedar Junction & 1 & 1 & 1 \\
\hline 38 & 06892500 & 20.7 & Kansas River at Bonner Springs & -- & 1 & 1 \\
\hline 39 & 06892502 & 20.3 & Bonner Springs sewage treatment effluent & 1 & 1 & 1 \\
\hline 40 & 06892504 & 19.4 & Kansas River near Lake of the Forest & -- & 1 & 1 \\
\hline 41 & 06892505 & 16.6 & Kansas River near Edwardsville & -- & 1 & 1 \\
\hline${ }^{2} 42$ & 06892515 & 16.1 & Mill Creek at Wilder Road & 1 & 1 & 1 \\
\hline 43 & 06892518 & 15.4 & Kansas River near I-435 bridge & -- & 1 & 1 \\
\hline 44 & 06892520 & 15.0 & Johnson County Mill Creek Regional sewage treatment effluent & 1 & 1 & 1 \\
\hline 45 & 06892525 & 14.8 & Kansas City sewage treatment effluent no. 20 & 1 & 1 & 1 \\
\hline 46 & 06892527 & 11.2 & $\begin{array}{l}\text { Unnamed tributary below Kansas City sewage treatment effluent } \\
\text { no. } 14\end{array}$ & 1 & 1 & 1 \\
\hline 47 & 06892530 & 9.7 & Kansas River at Turner Bridge & -- & 1 & 3 \\
\hline 48 & 06892540 & 6.0 & Kansas River at West Kansas Avenue Bridge & 1 & 1 & 2 \\
\hline 49 & 06892942 & 3.2 & Turkey Creek at Kansas City near I-35 & 1 & 1 & 1 \\
\hline 50 & 06892960 & 1.1 & Kansas River above Missouri River confluence & 1 & 1 & 4 \\
\hline Total & & & & 24 & 49 & 74 \\
\hline
\end{tabular}

${ }^{1}$ Synoptic survey I occurred November 27-29, 2001; synoptic survey II occurred February 25-March 1, 2002; synoptic survey III occurred July 22-August 8, 2002.

${ }^{2}$ Sampling site where a continuous water-quality monitor was installed for 1 to 10 days during synoptic survey III.

Beachwood, Ohio, using a Leica inverted compound microscope with 150X, 300X, 600X, and 1,000X objectives and epifluorescence. The magnification used depended on the size of the dominant taxa and the size and number of particulates. The goal was to count at multiple magnifications to correctly enumerate and identify taxa present that varied in size by several orders of magnitude. If the sample was dominated by cells or natural units less than 10 to $20 \mu \mathrm{m}$ or if the cells were fragile and difficult to identify, the majority of counting was completed at $600 \mathrm{X}$ to $1,000 \mathrm{X}$ magnification.

Natural units enumerated included single cells, filaments, or colonies. The abundance of all phytoplankton taxa was calculated as cells per liter and then multiplied by the biovolume for one cell of that species. The abundance of common taxa was estimated by random field counts. The goal, regardless of magnification, was to enumerate and identify a minimum of 400 natural units per sample exclusive of miscellaneous microflagellates. Extremely sparse samples or samples with high particulates yielded less than 400 natural units. For samples with common colonies or filaments, the counts included several thousand cells because total cell numbers of multicell units (colonies, filaments) were quantified. In accord with Lund and others (1958), the data were accurate to within 90-percent confidence limits. 
Duplicate and blank samples were analyzed to provide quality assurance of laboratory analytical precision and reproducibility, and cleaning techniques. The percentage difference of duplicate samples was calculated using equation 1:

where

$$
\text { percentage difference }=\frac{\left|C_{1}-C_{2}\right|}{\frac{\left|C_{1}+C_{2}\right|}{2}},
$$

$C_{1}$ is the concentration or density for the first sample; and $C_{2}$ is the concentration or density for the duplicate sample.

The percentage difference for all the chemical and bacteria duplicate samples ranged from 0.09 to 27 percent and 12 to 20 percent, respectively. Differences of less than 20 percent for chemical analysis were acceptable. However, differences greater than 20 percent may indicate analytical or sampling deficiencies. Possible causes for the large uncertainty in the bacteria results are discussed in a USGS report by Rasmussen and Ziegler (2003).

Eighteen USGS streamflow-gaging stations were located within the study area during the study period, 6 on the Kansas River and 12 on various tributaries (fig. 2). A continuous record of stream stage (water-surface elevation) was recorded at each station using pressure transducers and electronic data-collection platforms. Daily mean streamflow was calculated at the stations by relating stream stage to measured streamflow using methods presented by Kennedy (1984).

Continuously recording (60-minute intervals) waterquality monitors were installed at USGS streamflow-gaging stations on the Kansas River at Wamego (station 06887500), Topeka (station 06889000), and DeSoto (station 06892350) during the study surveys. Water-quality properties measured with the monitors included specific conductance, $\mathrm{pH}$, water temperature, turbidity, and dissolved oxygen. Measurements were logged hourly and transmitted every 4 hours via satellite to the USGS office in Lawrence, Kansas, and were made available in real time on the World Wide Web http://ks.water.usgs.gov/Kansas/rtqw/). The water-quality monitors were inspected onsite by USGS personnel approximately monthly to maintain calibration. Guidelines and standard procedures for maintaining the sites and reporting the data are described in Wagner and others (2000). These continuous data can be used to develop surrogate relations between realtime data and samples collected to provide continuous estimates for selected constituents (Christensen and others, 2000; Rasmussen and Ziegler, 2003).

During synoptic survey III (July 22-August 8, 2002), continuously recording water-quality monitors were temporarily installed for several days in the Kansas River at Lecompton (station 06891000) and Kansas City (station 06892960) and for about 24 hours near the mouth of Soldier Creek, Wakarusa River, and Mill Creek in Johnson County. The data from these monitors were used to verify input values for the water-quality model. Measurements of specific conductance, $\mathrm{pH}$, water temperature, turbidity, and dissolved oxygen were logged hourly. All of the temporarily installed monitors were cleaned and calibrated prior to installation, and the monitors at Lecompton and
Kansas City also were cleaned and calibrated 1 week after installation and prior to removal.

\section{Hydrologic and Water-Quality Conditions}

Hydrologic and water-quality conditions during the study period are summarized in this section. Analytical results of the water samples collected are listed in Appendix 1 at the back of this report. Spatial variations in water quality for the three synoptic surveys are described as well as seasonal variation between winter (synoptic surveys I and II) and summer (synoptic survey III) conditions. Some temporal comparisons are made for synoptic survey III. Comparison of analytical results to State water-quality criteria also are provided.

\section{Hydrologic Conditions}

Long-term (1971-2000) average monthly streamflows for the Kansas River at Topeka (station 06889000) and DeSoto (station 06892350) indicated that January had the smallest flows and that May had the largest average monthly streamflows (fig. 5). Comparisons of average monthly streamflows for the Kansas River at Topeka and DeSoto from November 2001 to August 2002 with long-term average monthly streamflow indicated that streamflows during the study period were from 17 to 87 percent less than the long-term normal (1971-2000).

KDHE uses the 30-day, 10-year low streamflow (30Q10) statistic for 1968-97 to determine mixing zones downstream from point-source discharges (Kansas Department of Health and Environment, 2002). The 30Q10 is defined as the streamflow below which the annual 30-day minimum falls in 1 year out of 10 as a long-term average. The recurrence interval of the $30 \mathrm{Q} 10$ is 10 years; the chance that the annual 30 -day minimum flow will be less than the $30 \mathrm{Q} 10$ is 10 percent in any given year. The 30Q10s for the Kansas River at Topeka, Lecompton, and DeSoto for 1971-2000 were calculated on the basis of streamflow data collected at USGS streamflow-gaging stations (fig. 2) and are compared to the 30Q10s that KDHE uses (1968-97) in table 4.

Differences in streamflow between sites on the Kansas River at Topeka, Lecompton, and DeSoto were caused by various factors. Daily mean streamflow varied from 740 to 9,600 $\mathrm{ft}^{3} / \mathrm{s}$ at Topeka, 900 to $13,500 \mathrm{ft}^{3} / \mathrm{s}$ at Lecompton, and 950 to $15,800 \mathrm{ft}^{3} / \mathrm{s}$ at DeSoto during the study (fig. $6 A$ ). Hourly streamflow fluctuation during the three synoptic surveys were caused by reservoir and low-water dam operation and rainfall (figs. $6 B-D$ ). Comparison of hourly streamflows for the Kansas River at Topeka and Lecompton during steady, low streamflow conditions indicates a 300 to $400 \mathrm{ft}^{3} / \mathrm{s}$ increase at Lecompton, suggesting that the river is gaining streamflow from its tributaries, point sources, and ground water (Wolf and Helgesen, 1992). The differences in hourly streamflows between 


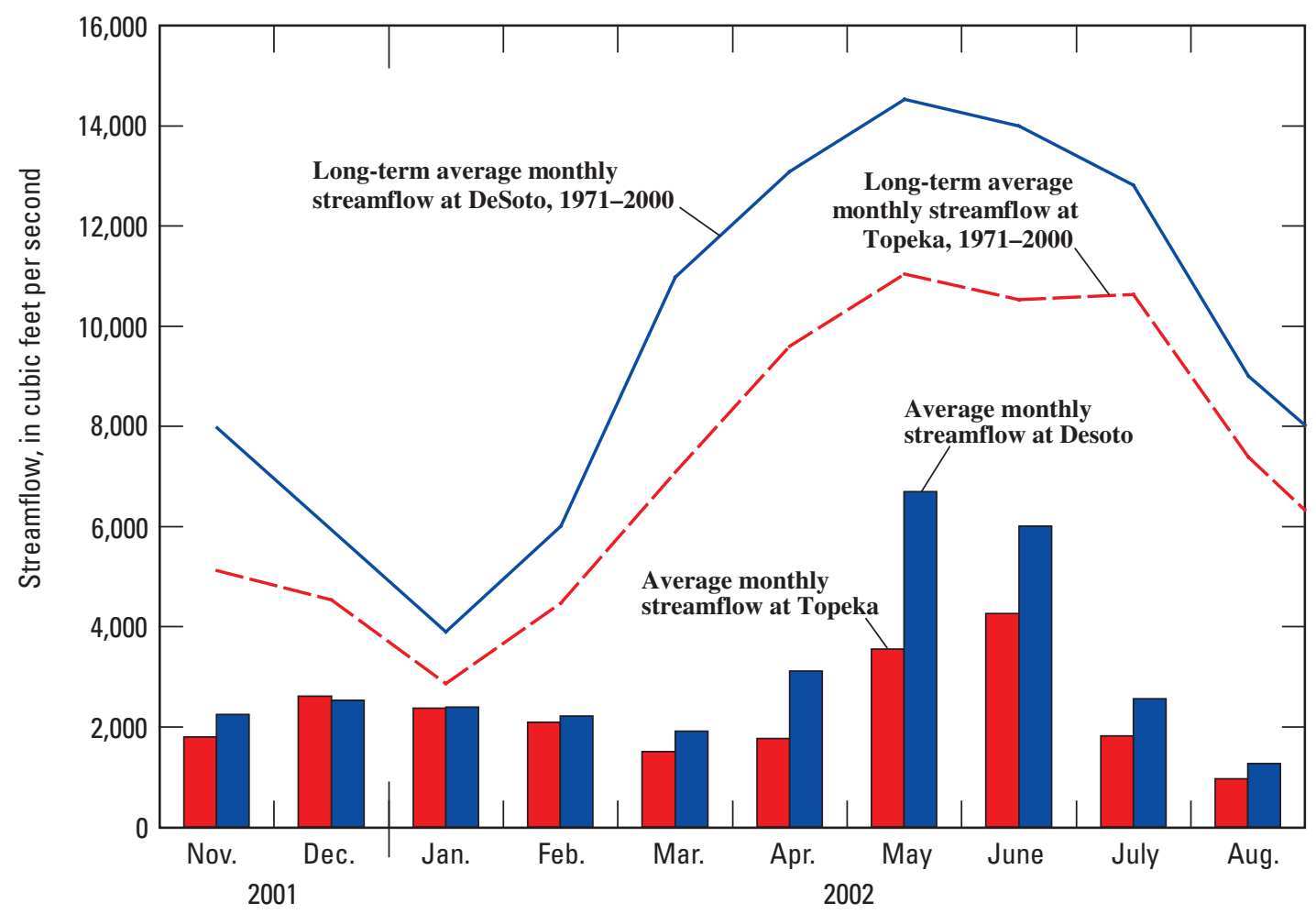

Figure 5. Long-term, average monthly streamflow, 1971-2000, and observed average monthly streamflow, November 2001 through August 2002, for Kansas River at Topeka and DeSoto.

Table 4. Calculated 30-day, 10-year low flows for the Kansas River at selected U.S. Geological Survey streamflow-gaging stations in northeast Kansas, 1971-2000 and 1968-97.

$\left[\mathrm{ft}^{3} / \mathrm{s}\right.$, cubic feet per second]

\begin{tabular}{|c|c|c|c|}
\hline $\begin{array}{l}\text { U.S. } \\
\text { Geological } \\
\text { station } \\
\text { number } \\
\text { (fig. 4) }\end{array}$ & Station name & $\begin{array}{c}\text { Streamflow, } \\
\text { 30-day, } \\
10 \text {-year low } \\
\left(\mathrm{ft}^{3} / \mathrm{s}\right), \\
1971-2000\end{array}$ & $\begin{array}{c}\text { Streamflow, } \\
\text { 30-day, } \\
\text { 10-year low } \\
\left(\mathrm{ft}^{3} / \mathrm{s}\right) \\
1968-97\end{array}$ \\
\hline 06887500 & $\begin{array}{l}\text { Kansas River at Wamego, } \\
\text { Kansas }\end{array}$ & 626 & 575 \\
\hline 06889000 & $\begin{array}{l}\text { Kansas River at Topeka, } \\
\text { Kansas }\end{array}$ & 677 & 670 \\
\hline 06891000 & $\begin{array}{l}\text { Kansas River at Lecompton, } \\
\text { Kansas }\end{array}$ & 802 & 765 \\
\hline 06892350 & $\begin{array}{l}\text { Kansas River at DeSoto, } \\
\text { Kansas }\end{array}$ & 856 & 830 \\
\hline
\end{tabular}

Lecompton and DeSoto were small, suggesting gains in streamflow from tributaries and point sources are offset by losses to withdrawals and ground- and surface-water interaction.

Mean daily streamflows varied from 340 to $170,000 \mathrm{ft}^{3} / \mathrm{s}$ at Topeka and 520 to $170,000 \mathrm{ft}^{3} / \mathrm{s}$ at DeSoto during the period 1971 through 2000 (fig. 7). Median mean daily streamflows for the 30-year period were $3,200 \mathrm{ft}^{3} / \mathrm{s}$ at Topeka and $4,400 \mathrm{ft}^{3} / \mathrm{s}$ at DeSoto. Mean daily streamflows for the Kansas River at Topeka and DeSoto during the synoptic surveys were 1,500 and
$2,100 \mathrm{ft}^{3} / \mathrm{s}$, respectively, for survey $\mathrm{I} ; 1,900$ and $1,900 \mathrm{ft}^{3} / \mathrm{s}$, respectively, for survey II; and 1,100 and 1,300 $\mathrm{ft}^{3} / \mathrm{s}$, respectively, for survey III. In comparison with the long-term duration curve, the average mean daily streamflows for the three synoptic surveys were greater than or equal to streamflows with exceedance probabilities of 70 percent or greater for the 30 -year period. Hourly streamflows during the three synoptic surveys were greater than both of the 30Q10 low flows at Topeka and DeSoto listed in table 4.

Streamflow in the Kansas River downstream from Lawrence is affected by a low-water dam that is operated by the Bowersock Mills and Power Company and used to generate electricity (fig. 8). The dam maintains about 4 to $6 \mathrm{ft}$ of head (the difference in elevation between the surface of the pool upstream from the dam and downstream from the dam) using baffles and boards to divert water to the powerplant to generate electrical output. The head and streamflow provide the energy necessary to turn the turbines of the generators to produce electricity. Maintenance and equipment failures are some of the reasons for lowering and raising the dam, creating extreme streamflow changes downstream from the dam during low-flow conditions.

The sum of the designed (maximum) discharges (Appendix 2) from the 37 wastewater discharge sites identified in figure 9 , is $159 \mathrm{ft}^{3} / \mathrm{s}$. The sum of the six largest WWTFs (Johnson County Mill Creek Regional (WWTF 33), Topeka Oakland (WWTF 8), Johnson County Nelson (WWTF 37), 


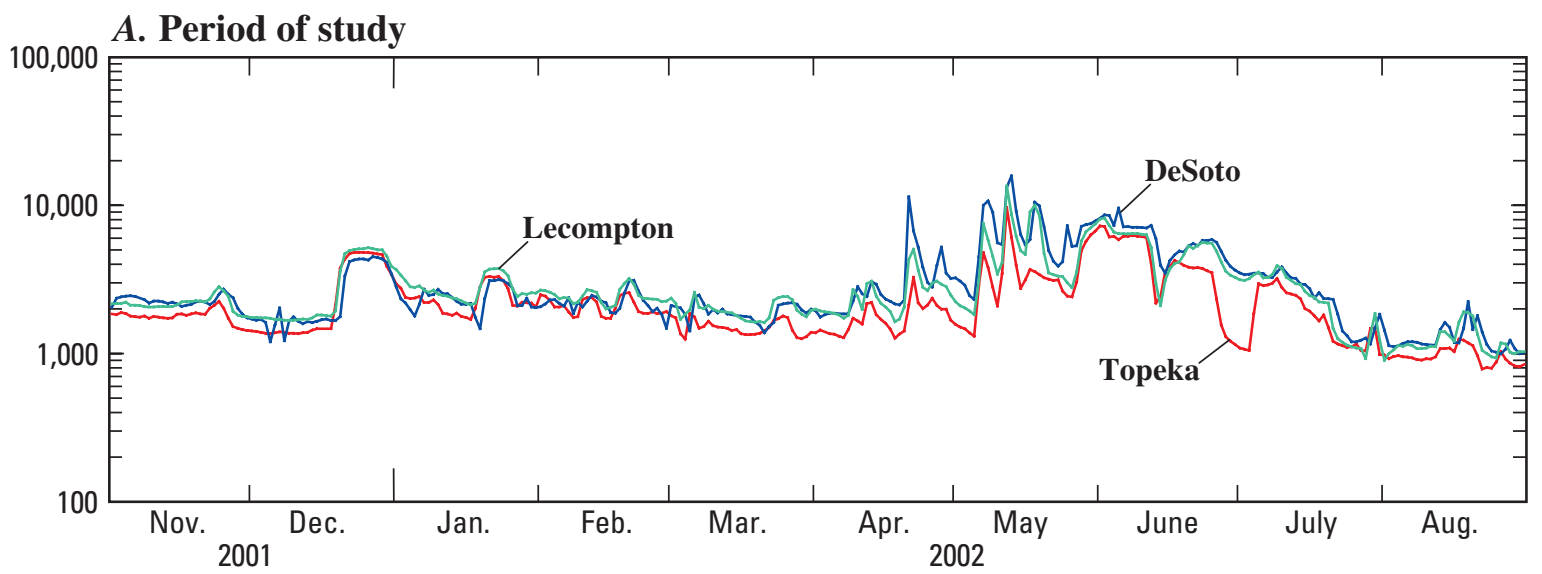

B. Synoptic survey I

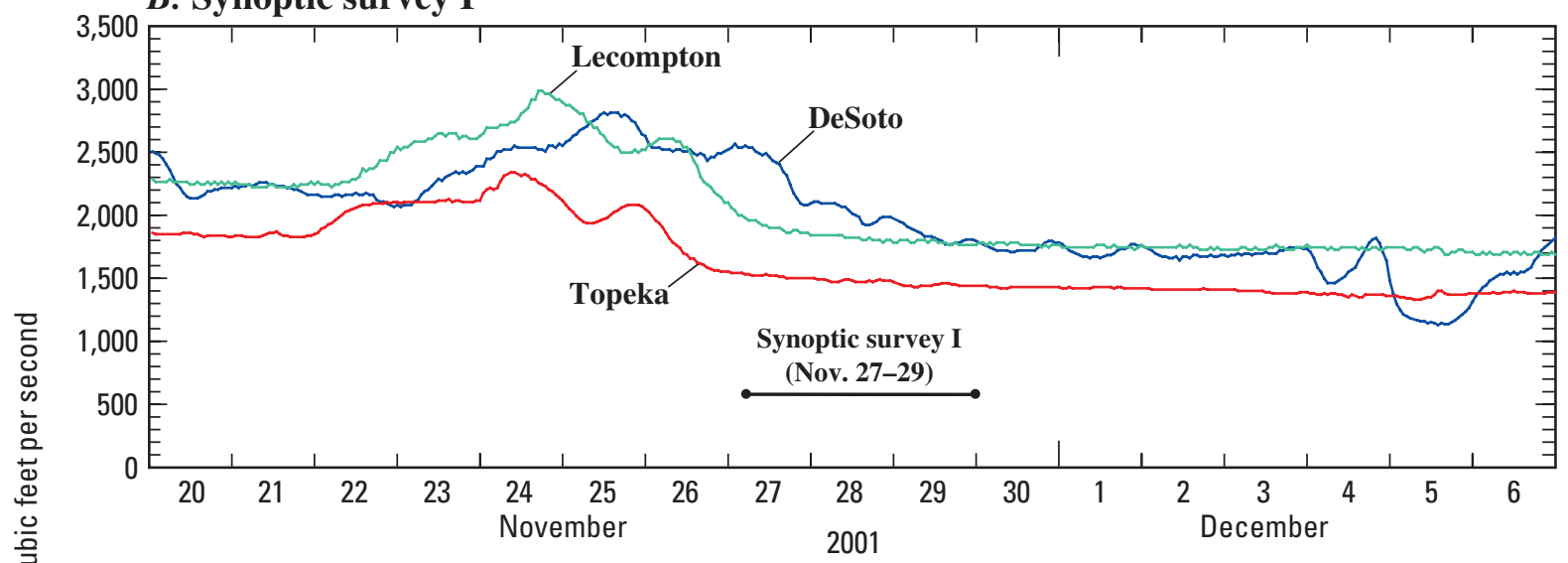

C. Synoptic survey II

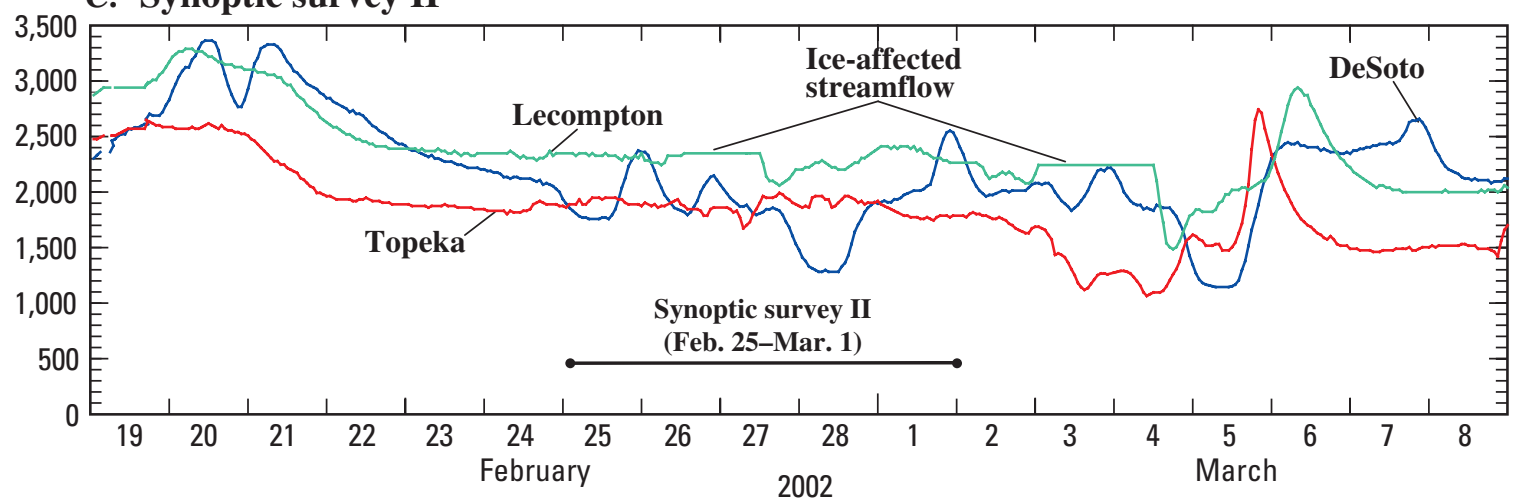

D. Synoptic survey III

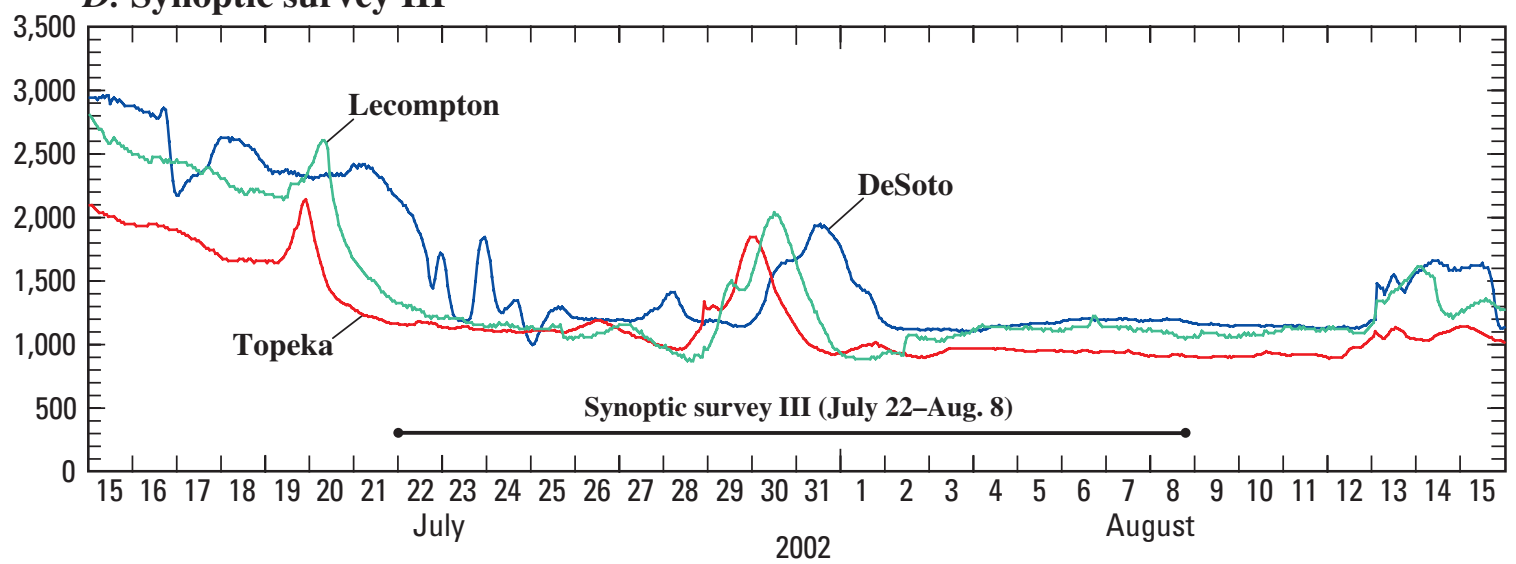

Figure 6. Daily mean and hourly streamflow in Kansas River at Topeka, Lecompton, and DeSoto, November 2001 through August 2002. 


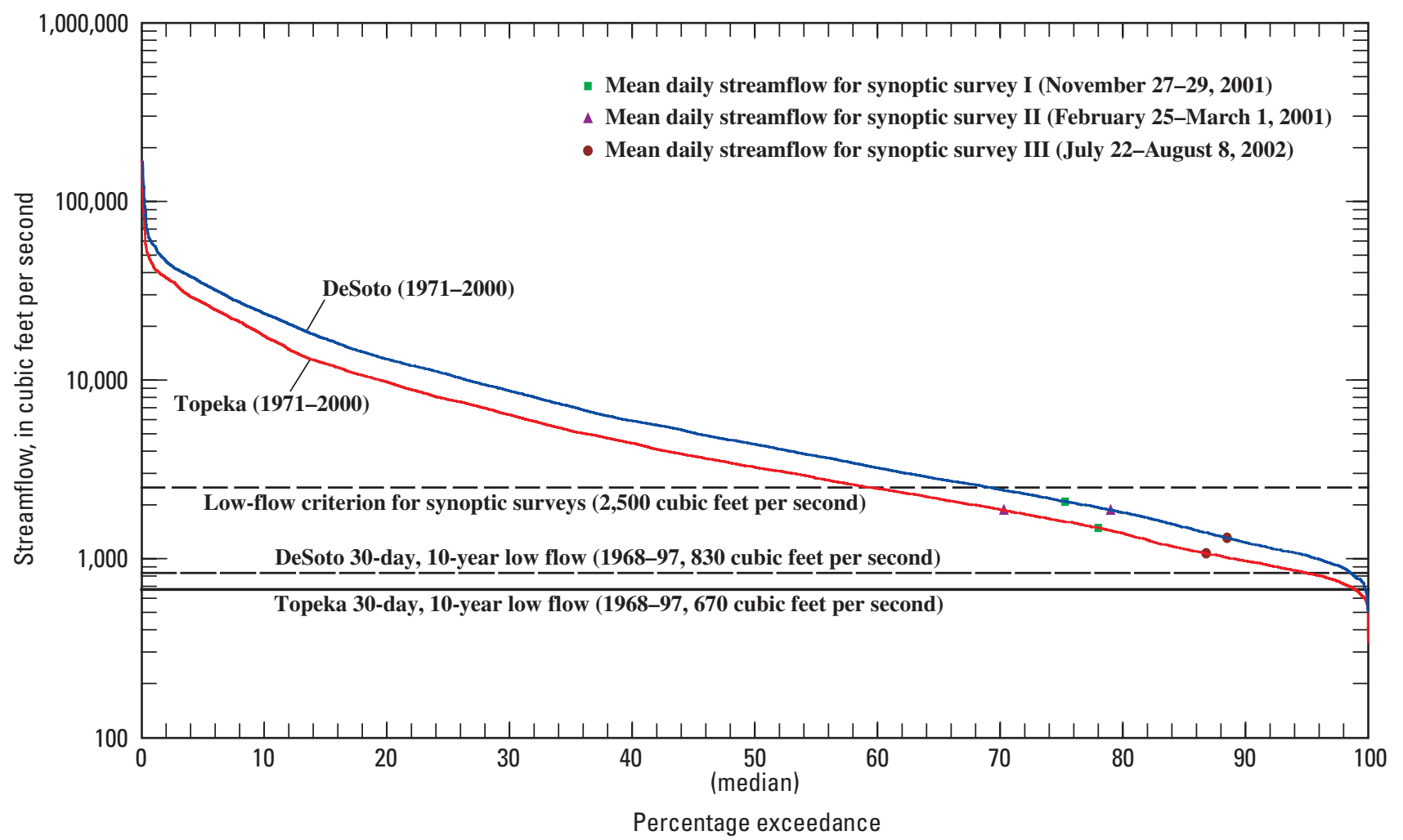

Figure 7. Streamflow duration curves, 30-day, 10-year low flows, and mean daily streamflow for 1971 through 2000 and for synoptic surveys from November 2001 through August 2002 for Kansas River at Topeka and DeSoto.

Lawrence (WWTF 16), North Topeka (WWTF 7), and Kansas City no. 20 WWTF (site 34 ) represents 79 percent of the total design flow. The cumulative design flow for the wastewater discharges upstream from Topeka (WWTF 8) and DeSoto

(WWTF 27) are 24 and $82 \mathrm{ft}^{3} / \mathrm{s}$, respectively. Currently, (2004) 48 percent of the cumulative WWTF design flow is discharged into the Kansas River downstream from DeSoto. The winter permitted ammonia loads are greatest for WWTFs serving large urban areas (Topeka, Lawrence, Kansas City; fig. 9). On the basis of projected population for the counties adjacent to the Kansas River (table 2), wastewater from the projected 2030 population growth in Johnson County has the greatest potential to increase the ammonia load in the WWTF effluent and affect the water quality of the Kansas River downstream from DeSoto.

Calculated cumulative streamflow values were compared to measured streamflow values on the main stem of the Kansas River to estimate surpluses and deficits of streamflow (fig. 10). Cumulative streamflow was calculated by starting with the streamflow of the Kansas River at Wamego or some site downstream and adding the measured streamflows from tributaries and WWTFs. In some cases, when there was a large difference between flow values of the instantaneous measurements made during sample collection and those reported by WWTFs, the flow value reported by the WWTF was used in the calculation of cumulative streamflow. Inflow from small tributaries and withdrawals from the Kansas River and surface- and ground-water interaction during these periods were not mea- sured. Withdrawals from the Kansas River for municipal water use typically are reported as a monthly value. These monthly values were not used in this comparison or in the model. Streamflows for tributaries and WWTFs (as reported by the facility) were assumed to be constant throughout each synoptic period. A surplus of streamflow occurred during synoptic survey I (fig. 10A) when main-stem measured streamflow values were greater than main-stem cumulative streamflow. Part of the reason for the apparent surplus was because the Kansas River flows were not in steady-state condition. Moreover, the measurements were made from downstream to upstream as streamflow in the Kansas River was decreasing (fig. $6 B$ ). The main-stem samples that were collected first near the confluence with the Missouri River were collected during streamflows of about $2,500 \mathrm{ft}^{3} / \mathrm{s}$ (fig. 10A). The last sample collected on the main stem near Topeka was at a streamflow of $1,400 \mathrm{ft}^{3} / \mathrm{s}$ (fig. $10 A$ ). For this reason, conclusions about unmeasured tributary inflow and ground-water flux during synoptic survey I can not be made with certainty.

Streamflow in the Kansas River was more stable at the Topeka and Lecompton USGS gaging stations during synoptic survey II (fig. 6C). Streamflow at the DeSoto USGS gage fluctuated as a result of of operations of Bowersock Dam. Measured streamflow and cumulative streamflow for the main-stem sites upstream from Bowersock Dam indicated that flow in the river increased slightly from upstream to downstream as tributaries and WWTFs flowed into the river (fig. 10B). Downstream from 


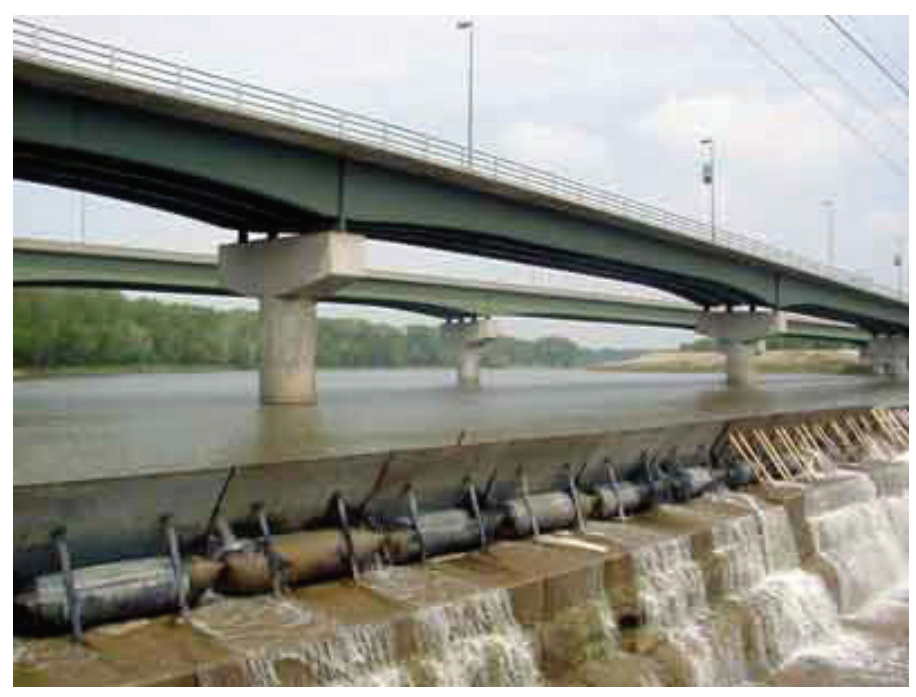

Figure 8. Bowersock Dam on Kansas River at Lawrence, Kansas (photograph courtesy of Bowersock Mills and Power Company, Lawrence, Kansas).

Bowersock Dam, streamflow varied hourly indicating that the operation of Bowersock Dam greatly affected the streamflow and increased the uncertainty of the comparison for this portion of the main stem.

During synoptic survey III (fig. 10C), streamflow in the Kansas River varied because of runoff from rainfall and operation of Bowersock Dam (fig. $6 D$ ). Samples and streamflow measurements for synoptic survey III on the main stem were collected either before or after the increased streamflow from runoff reached the sampling site. A few streamflow measurements on the Kansas River were made that were affected by the runoff. The variability of the main-stem streamflow was reflected at the sampling sites where more than one sample was collected. For instance, instantaneous streamflow for each sample collected at the USGS streamflow gage at Lecompton (site 21) ranged from 830 to $1,300 \mathrm{ft}^{3} / \mathrm{s}$. The hourly streamflow data from the DeSoto streamflow gage indicated that the operation of Bowersock Dam affected streamflow only for the first 3 to 4 days of synoptic survey III (fig. $6 D$ ). Therefore, flows in the Kansas River measured during that period at sites downstream from Bowersock Dam (downstream from site 24) were affected by dam operations.

Streamflow contributed by all the measured tributaries (18) and WWTFs (8) during synoptic survey III was about $140 \mathrm{ft}^{3} / \mathrm{s}$ and accounted for 13 percent of the total streamflow at the mouth. The measured main-stem streamflow decreased from Wamego (site 1) to Topeka (site 12) and then gradually increased from Topeka to just upstream from Bowersock Dam (site 24). This slight streamflow increase is similar to the rate of increase indicated by the main-stem cumulative streamflow for this reach. The comparison between measured and calculated main-stem cumulative streamflow demonstrates that, for the reach between Topeka (river mile 85) and Lawrence (river mile
56), the Kansas River is gaining streamflow from tributaries, WWTFs, and ground water.

The comparison between measured and calculated cumulative streamflow of the Kansas River downstream from Bowersock Dam to the confluence with the Missouri River indicated that, in general, streamflow increased. The rate of increase for main-stem measured streamflow exceeded the rate of increase for calculated main-stem cumulative streamflow. There are several possible explanations for this. The daily operation of Bowersock Dam coupled with the timing of the measurements could have created the variation between the measured and cumulative streamflow, or the river reach could be receiving ground water and, therefore, increasing the streamflow. Another explanation is that the assumption that the magnitude of the flow from the tributaries and WWTFs was constant was incorrect. The streamflow for the gaged tributaries indicated no evidence of an increase in streamflow. It is possible that the discharge from the WWTFs increased during this period, but even if every WWTF was discharging at full design capacity, the resulting increased streamflow is not enough to make up the difference. Of the possibilities, the timing of the streamflow measurements and the ground-water inflow increasing the streamflow in the Kansas River are the most likely causes of differences between measured and calculated cumulative streamflow.

\section{Physical Water-Quality Characteristics}

Physical water-quality characteristics (specific conductance, $\mathrm{pH}$, water temperature, turbidity, and dissolved oxygen) in the Kansas River are affected greatly by the magnitude of streamflow, amount of daily solar radiation available, and the clarity of the water. Fluctuations and extremes in physical water-quality characteristics can result in unfavorable conditions for the survival of fish and other aquatic species. This section discusses hourly measurements of these physical characteristics of water in the Kansas River at Wamego, Topeka, and DeSoto.

\section{Specific Conductance}

Specific conductance describes the ability of water to conduct an electrical current and provides an indication of ion concentrations or dissolved solids. Pure water has a very small electrical conductance. Concentrations of dissolved solids increase as specific conductance increases (Hem, 1992). Measurements of specific conductance along the Kansas River can indicate point-source inflows and ground- and surface-water interaction. There are no water-quality criteria for specific conductance in Kansas.

Specific conductance generally varied inversely with streamflow (fig. 11). During low streamflow conditions, when reservoir releases were relatively small, streamflow was 


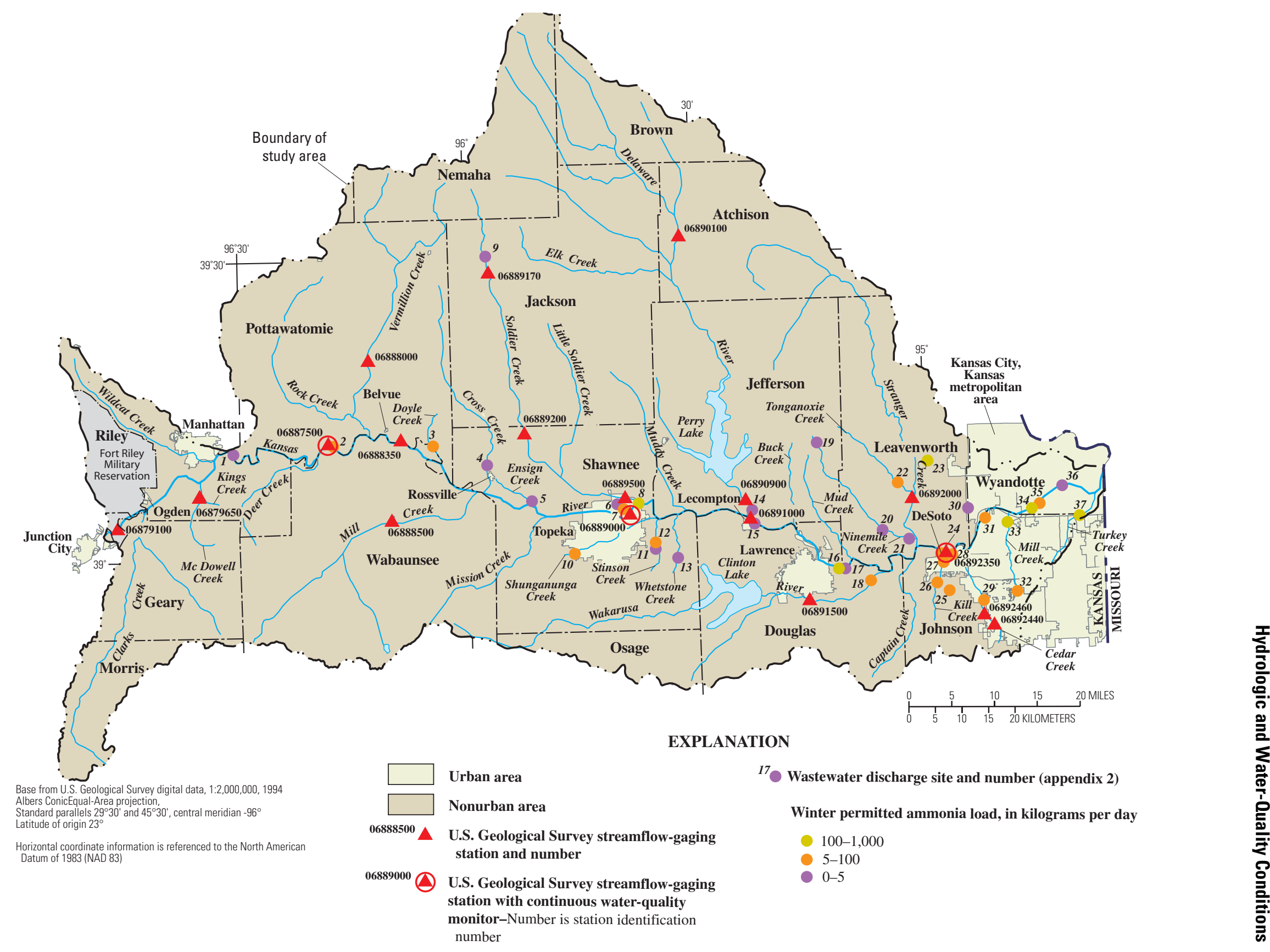

Figure 9. Location of U.S. Geological Survey streamflow-gaging stations, continuous water-quality monitors, and wastewater discharge sites in study area. 
A. Synoptic survey I, November 27-29, 2001

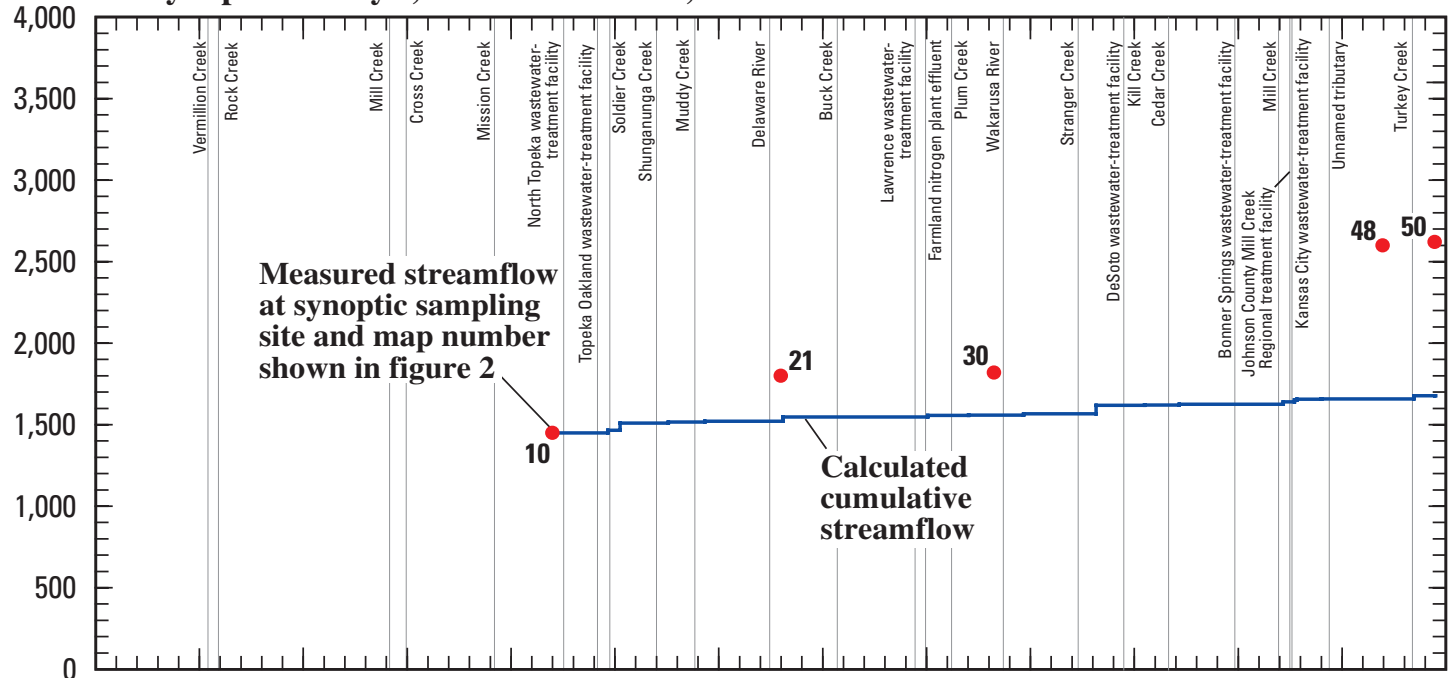

B. Synoptic survey II, February 25-March 1, 2002

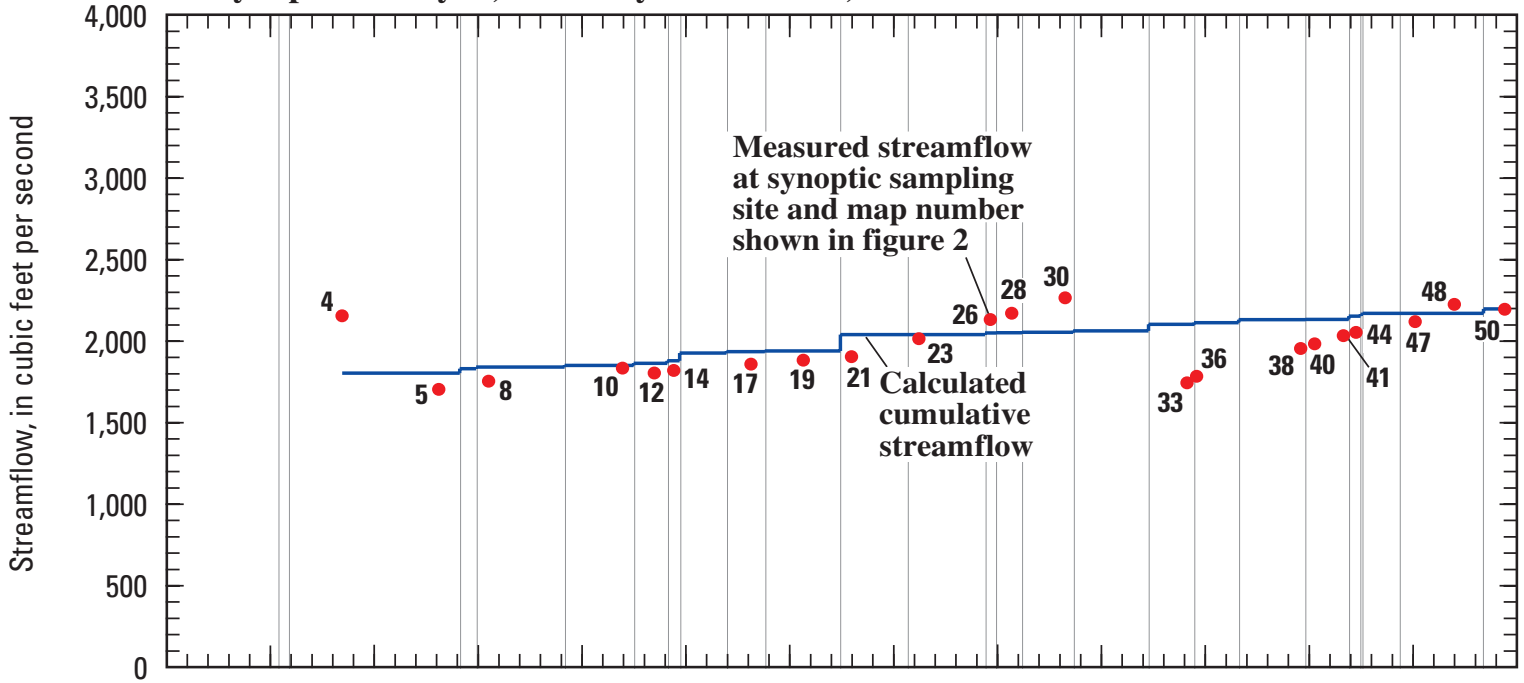

C. Synoptic survey III, July 22-August 8, 2002

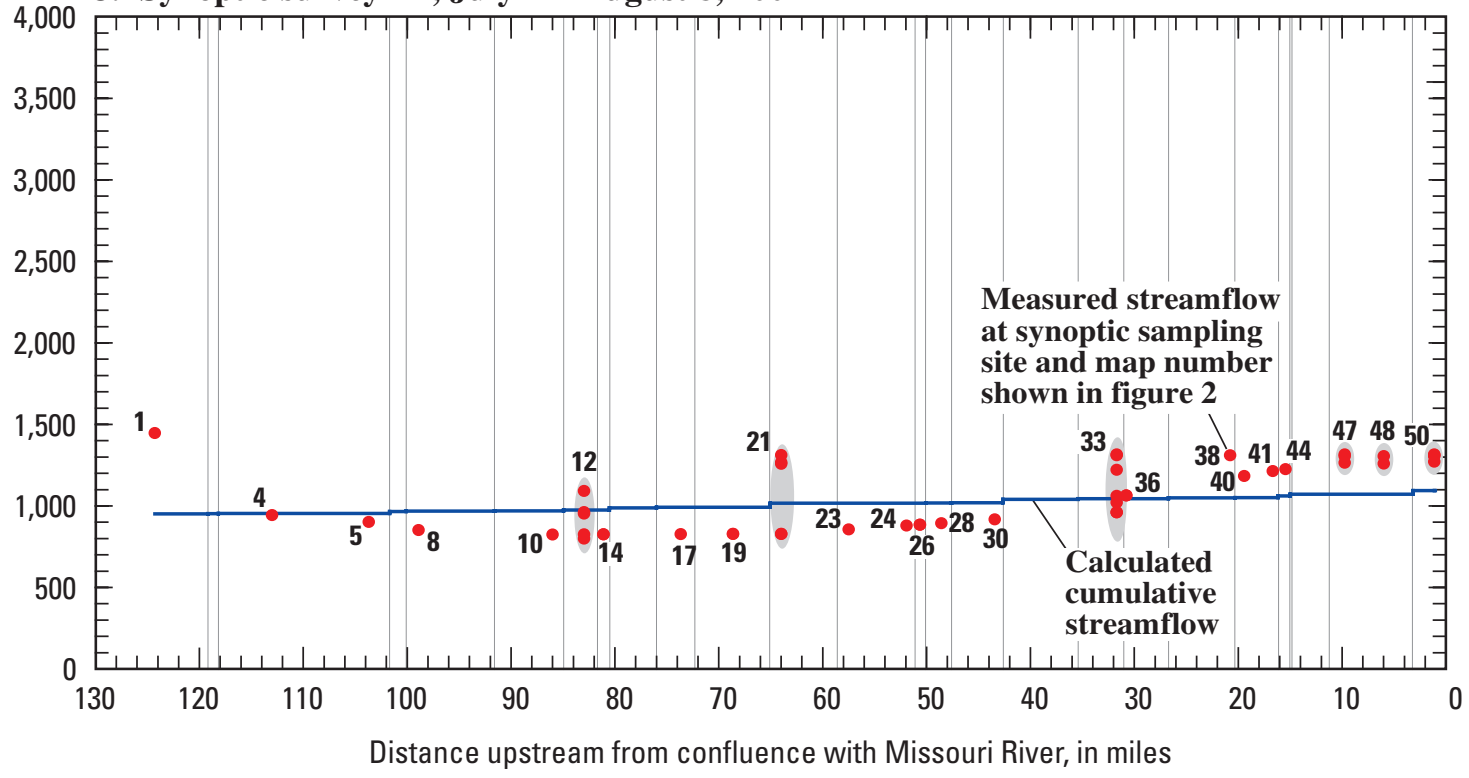

Figure 10. Comparison of measured streamflow in Kansas River with cumulative streamflow calculated from measured inputs and withdrawals during synoptic surveys I, II, and III, November 2001 through August 2002. Location of synoptic sampling sites shown in figure 2. Gray shading indicates multiple samples collected at a single site. 
A. Kansas River at Wamego (station 06887500, fig. 2)

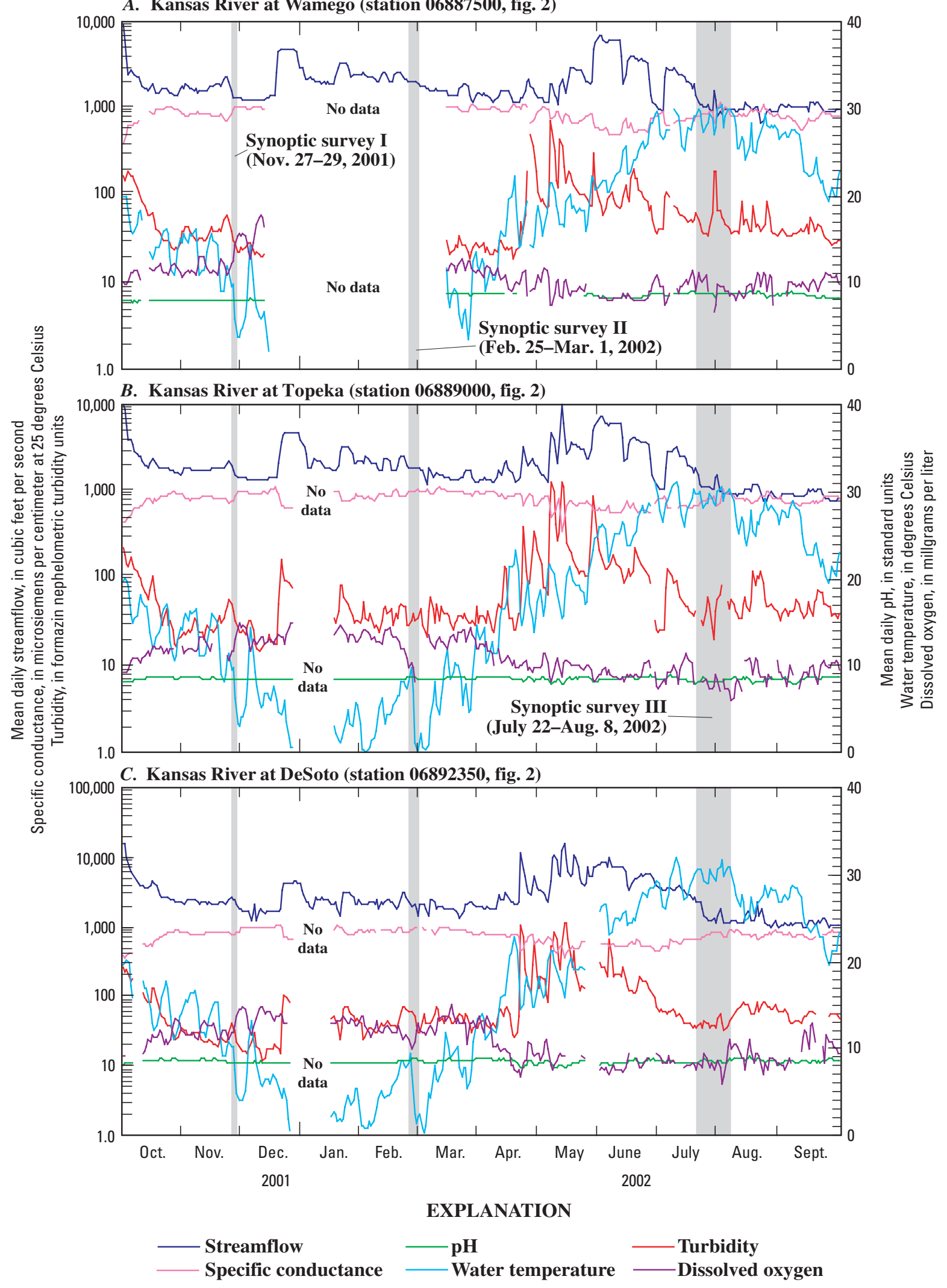

Figure 11. Mean daily values for streamflow, specific conductance, $\mathrm{pH}$, water temperature, turbidity, and dissolved oxygen in Kansas River at (A) Wamego, (B) Topeka, and (C) DeSoto, November 2001-August 2002. 
primarily from ground water and, therefore, contained large dissolved-solids concentrations (that is, large specific conductance values). When reservoir releases within the watershed increased, subsequent specific conductance values decreased. Mean daily specific conductance for the Kansas River at Topeka during the three synoptic periods ranged from $351 \mu \mathrm{S} / \mathrm{cm}$ at $25{ }^{\circ} \mathrm{C}$ during the largest streamflow to $1,101 \mu \mathrm{S} / \mathrm{cm}$ at $25{ }^{\circ} \mathrm{C}$ when streamflow in the Kansas River was less than $2,500 \mathrm{ft}^{3} / \mathrm{s}$ (fig. 11B).

\section{$\mathrm{pH}$}

Hydrogen-ion activity or content is measured with $\mathrm{pH}$. As the hydrogen-ion activity increases, $\mathrm{pH}$ values decrease to values less than 7.0 standard units and exhibit acidic properties. $\mathrm{pH}$ values greater than 7.0 standard units exhibit alkaline properties and a decrease in hydrogen activity. KDHE aquatic-life-support use criterion for $\mathrm{pH}$ is not less than 6.5 and not more than 8.5 standard units (Kansas Department of Health and Environment, 2002). Hourly values of $\mathrm{pH}$ greater than 8.5 standard units occurred during 25 percent of the period October 2000 through September 2003 (different from study period so that the plot is an annual exceedance curve) for the Kansas River at Topeka (fig. 12). Forty and 19 percent of the hourly $\mathrm{pH}$ values in the Kansas River at Topeka for synoptic surveys II and III, respectively, were greater than 8.5 standard units.
The $\mathrm{pH}$ of a stream is an important factor when considering the toxicity of ammonia for fish. KDHE aquatic-life criteria for ammonia reflect the relation of $\mathrm{pH}$ and ammonia toxicity (fig. 13). For example, the acute aquatic-life criterion for ammonia at a $\mathrm{pH}$ of 7.0 standard units is $36.1 \mathrm{mg} / \mathrm{L}$, whereas, for a $\mathrm{pH}$ value of 8.5 , the criterion is $3.2 \mathrm{mg} / \mathrm{L}$ (fig. 13A). These criteria indicate that as $\mathrm{pH}$ increases so does the toxicity of ammonia.

In general, the $\mathrm{pH}$ of the Kansas River was slightly basic during the study period ranging from 8.0 to 9.0 standard units (fig. 11). Variations in $\mathrm{pH}$ are primarily diurnal, although there were some large streamflows that decreased the $\mathrm{pH}$ of the Kansas River. Diurnal fluctuation of $\mathrm{pH}$ is caused primarily by photosynthesis in aquatic organisms that take up dissolved carbon dioxide during the daylight and then release carbon dioxide at night by respiration (Hem, 1992). The amplitude of the diurnal variations increased during the summer months (synoptic survey III) when streamflow was small and water temperature was high. During the two large runoff periods (May 7 and May 13, 2002), mean daily $\mathrm{pH}$ decreased to values of 8.2 and 7.9 standard units, respectively, in the Kansas River at Topeka. The smallest mean daily pH (7.8 standard units) occurred during minor runoff in the summer (August 17, 2002). The maximum mean daily $\mathrm{pH}$ value was 8.8 standard units and occurred June 26, 2002, during low streamflow conditions (less than $2,500 \mathrm{ft}^{3} / \mathrm{s}$ ). The average $\mathrm{pH}$ for the three synoptic surveys

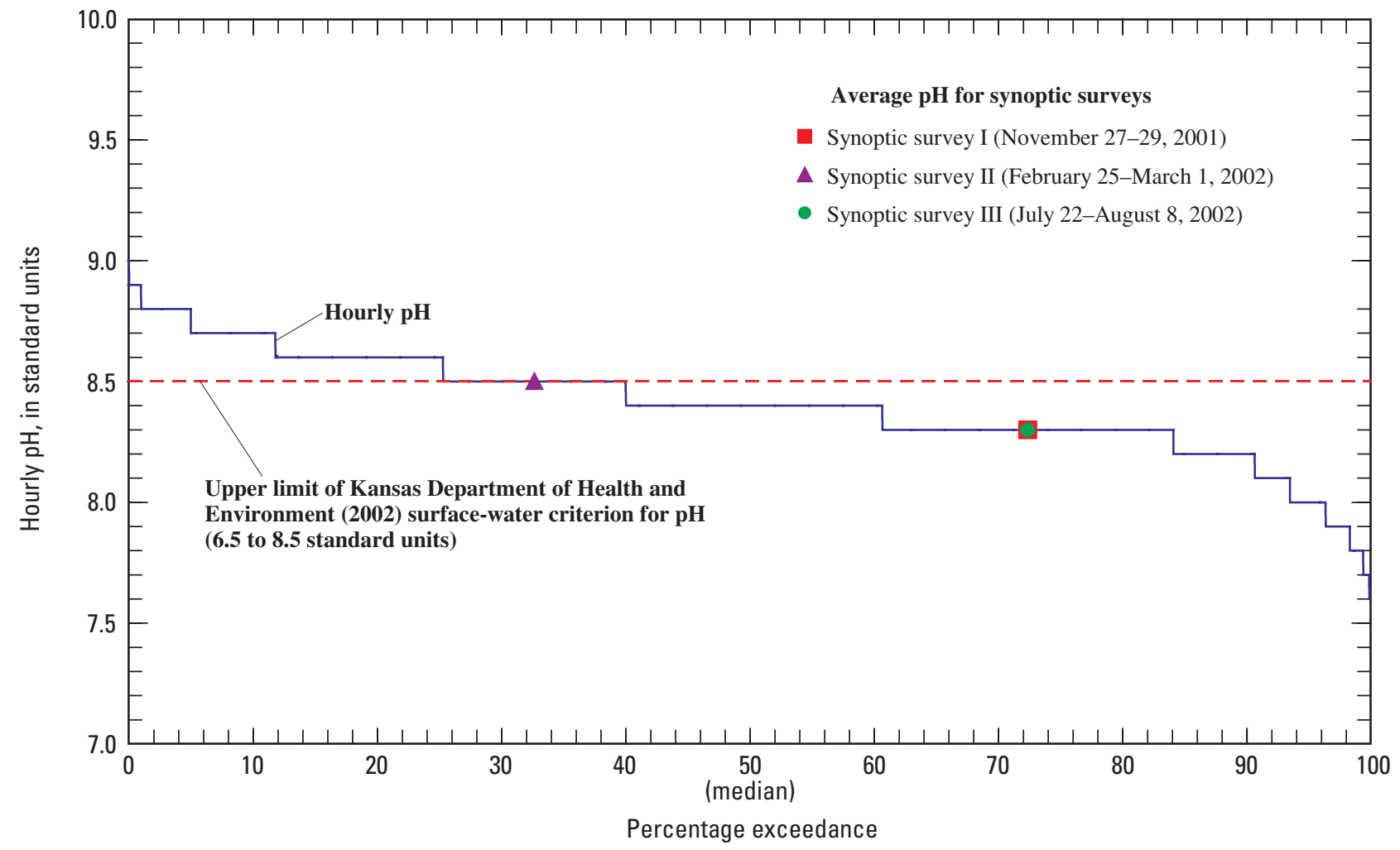

Figure 12. Duration curve for $\mathrm{pH}$ in Kansas River at Topeka (station 06889000, fig. 2), October 2000 through September 2003, and average $\mathrm{pH}$ for each synoptic survey. 
A. pH-dependent acute aquatic-life criteria for total ammonia as nitrogen

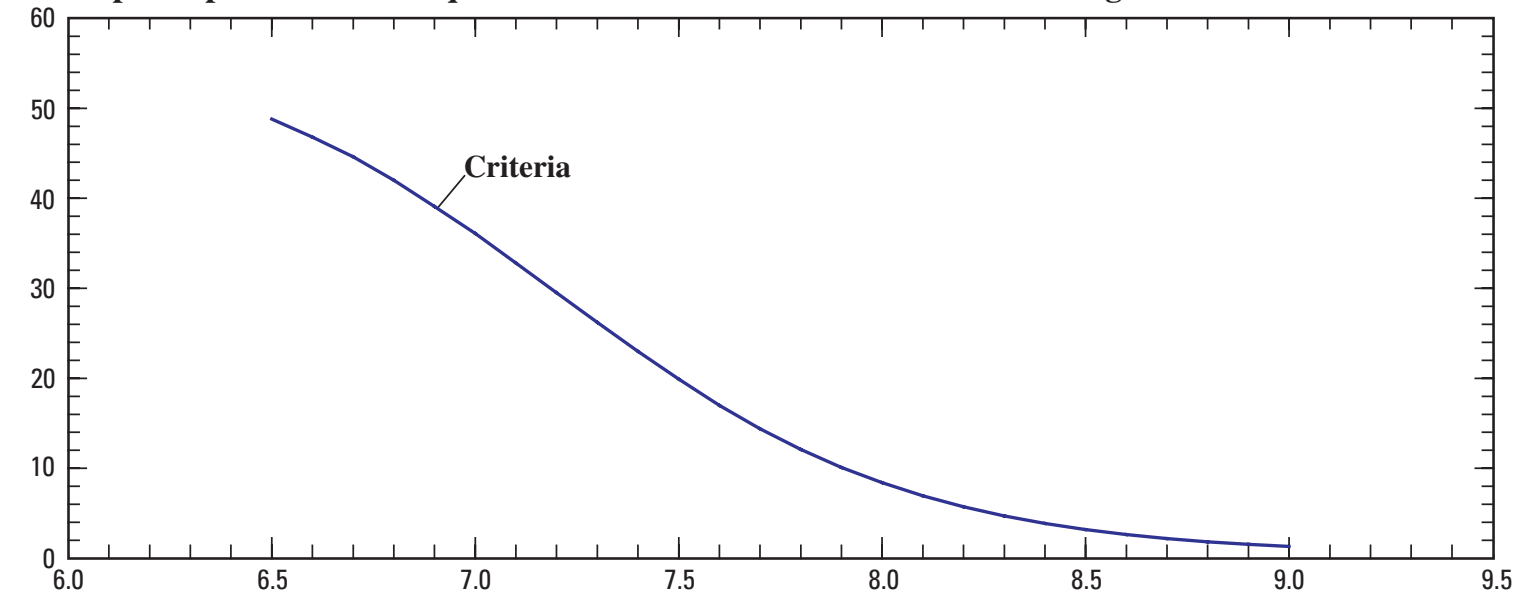

B. pH and water-temperature-dependent chronic aquatic-life criteria for total ammonia as nitrogen with early life

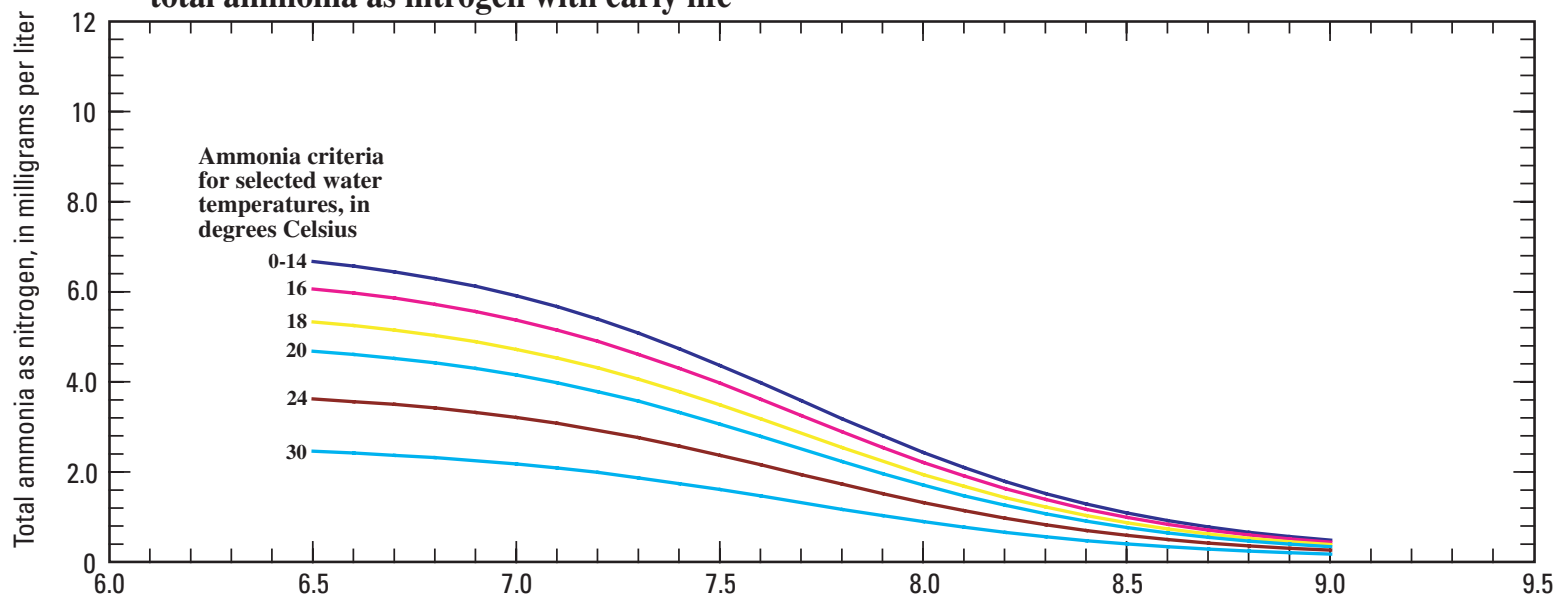

C. $\mathrm{pH}$ and water-temperature-dependent chronic aquatic-life criteria for total ammonia as nitrogen

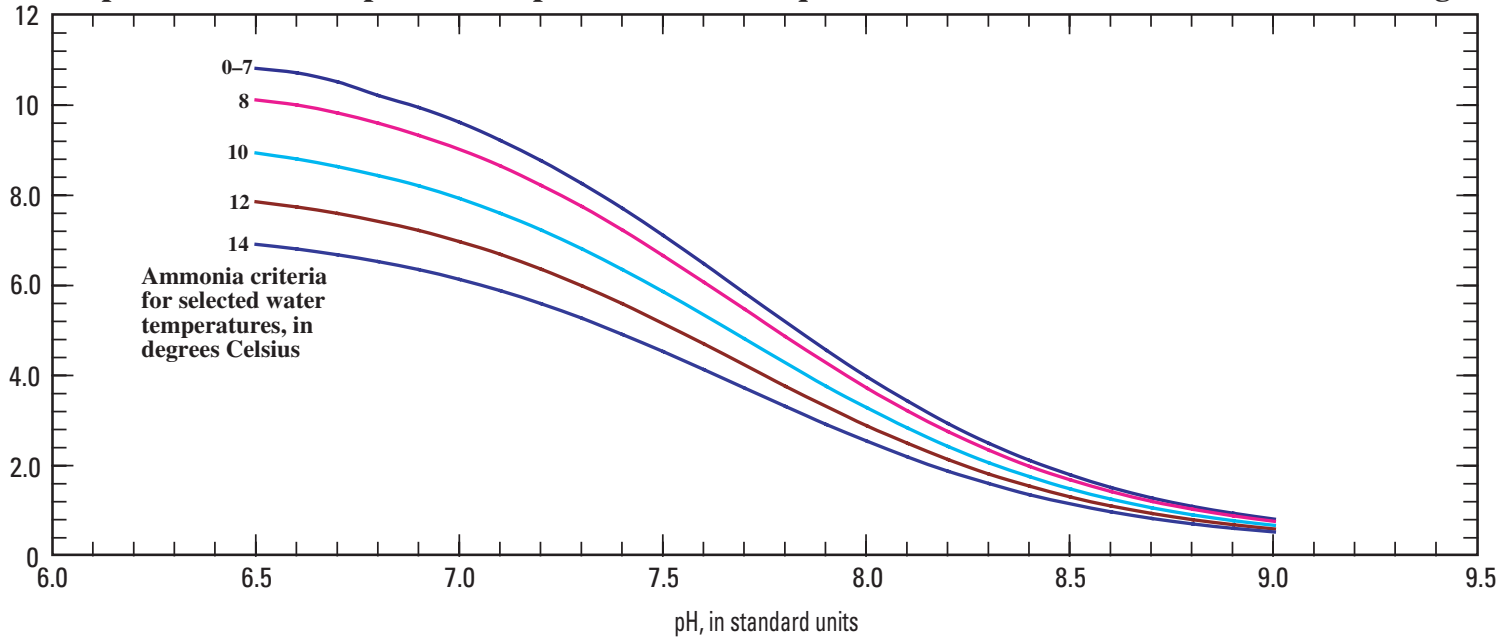

Figure 13. Acute and chronic aquatic-life criteria for total ammonia as nitrogen (criteria from Kansas Department of Health and Environment, 2002). 
ranged from 8.3 to 8.5 . The minimum and maximum observed during the synoptic surveys was 7.6 and 8.9 standard units, respectively, and both were observed during synoptic survey III.

\section{Water Temperature}

Water temperature also is important when determining the chronic aquatic-life criteria for ammonia (fig. 13). At a pH of 8.0 standard units, the ammonia criterion for early life stages present is $2.3 \mathrm{mg} / \mathrm{L}$ at a water temperature of $14{ }^{\circ} \mathrm{C}$ and $0.90 \mathrm{mg} / \mathrm{L}$ at a water temperature of $30{ }^{\circ} \mathrm{C}$ (Kansas Department of Health and Environment, 2002). These criteria suggest that as water temperature and $\mathrm{pH}$ increase so does ammonia toxicity in fish.

Mean daily water-temperature data (fig. 11) from the Kansas River at Wamego, Topeka, and DeSoto indicated seasonal and daily variations. Water temperature variations during low streamflow conditions were related primarily to the amount of daily solar radiation available. Mean daily water temperatures varied from $0{ }^{\circ} \mathrm{C}$ in the winter (synoptic surveys I and II) to more than $30{ }^{\circ} \mathrm{C}$ in the summer (synoptic survey III). The minimum, median, and maximum water temperatures in the Kansas River at Topeka for the study period were $0,17.8$, and $33.0^{\circ} \mathrm{C}$, respectively (fig. 14). The hourly water temperature of the Kansas River at Topeka varied from 2.5 to $29.2{ }^{\circ} \mathrm{C}$ during synoptic surveys II and III, respectively. Diurnal variations were as much as $5{ }^{\circ} \mathrm{C}$. Synoptic surveys II and III were conducted during the low and high water temperature extremes, respectively, for the study period.

\section{Turbidity}

Turbidity is the reduction in the transparency of a solution due to the presence of suspended and dissolved substances. Primary contributors to turbidity in water include clay, silt, finely divided organic and inorganic matter, soluble colored organic compounds, plankton, and microscopic organisms (American Public Health Association and others, 1992). Turbidity can inhibit light penetration into the water, reducing the photosynthesis of the aquatic organisms and plants and, therefore, affecting dissolved-oxygen and ammonia concentrations in the water.

Turbidity in the Kansas River at Topeka ranged from 15 to greater than 1,000 formazin nephelometric turbidity units (FNU) (fig. 11B). The larger turbidity values generally were associated with increased streamflow usually due to rainfall and subsequent runoff. During low streamflow conditions, turbidity values generally were less than 100 FNU. During the three synoptic surveys, hourly turbidity in the Kansas River at Topeka ranged from 8 to $99 \mathrm{FNU}$.

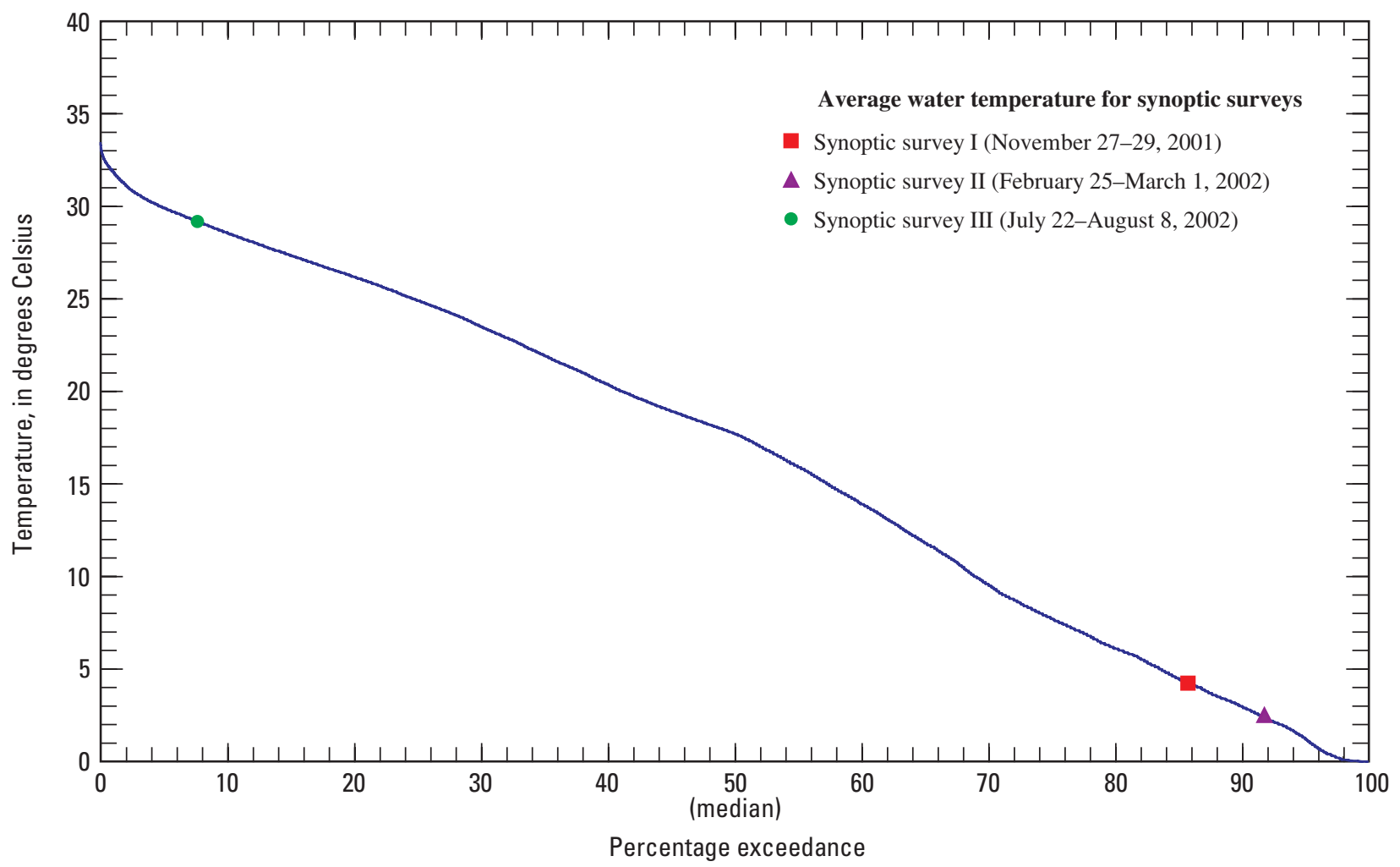

Figure 14. Duration curve for water temperature in Kansas River at Topeka (station 06889000, fig. 2), 0ctober 2000 through September 2003, and mean daily water temperature for each synoptic survey. 


\section{Dissolved Oxygen}

Dissolved-oxygen concentrations are used extensively to evaluate the ability of a stream to support higher forms of aquatic life that require oxygen for survival (Hem, 1992). During the day, photosynthesizing biota can produce oxygen, elevating dissolved-oxygen concentrations. Conversely, at night, organisms die causing the concentration of dissolved oxygen to decrease. KDHE's surface-water-quality criterion for dissolved oxygen is $5.0 \mathrm{mg} / \mathrm{L}$ (Kansas Department of Health and Environment, 2002). Stream segments with dissolved-oxygen concentrations less than $5.0 \mathrm{mg} / \mathrm{L}$ are considered impaired for aquatic life.

Dissolved-oxygen concentrations varied seasonally and diurnally (fig. 11) throughout the study period. Dissolved-oxygen concentrations in the Kansas River at Topeka (fig. 11B) reached minimum $(4.2 \mathrm{mg} / \mathrm{L})$ in late summer and maximum $(16 \mathrm{mg} / \mathrm{L})$ in the early spring, both during low streamflow conditions (streamflow less than $2,500 \mathrm{ft}^{3} / \mathrm{s}$ ). The average dissolved-oxygen concentrations for the three synoptic surveys were $14 \mathrm{mg} / \mathrm{L}$ for synoptic survey I, $9.0 \mathrm{mg} / \mathrm{L}$ for synoptic survey II, and $7.5 \mathrm{mg} / \mathrm{L}$ for synoptic survey III (fig. 15). The maximum and minimum hourly dissolved-oxygen concentrations for the three synoptic surveys were 15 and $4.4 \mathrm{mg} / \mathrm{L}$ measured during synoptic survey I and III, respectively. The magnitude of the amplitude of diurnal variation increased during the summer when streamflow was low and water temperatures were highest. Some aquatic organisms thrive under such conditions, producing dissolved oxygen by photosynthesis during the day. At night, photosynthesis ceases, and dissolved oxygen is consumed by fish, sediment, and bacteria that consume organic material. During the summer, it was not uncommon for the daily maximum dissolved-oxygen concentration to reach $15 \mathrm{mg} / \mathrm{L}$ and the minimum to reach $5.0 \mathrm{mg} / \mathrm{L}$. There were several days during synoptic survey III when some of the hourly dissolvedoxygen measurements were less than the KDHE aquatic-lifesupport use criterion $(5.0 \mathrm{mg} / \mathrm{L})$ (Kansas Department of Health and Environment, 2002).

\section{Chemical and Biological Constituent Concentrations and Comparison of Measured and Calculated Constituent Loads}

Water-quality conditions in the Kansas River are affected greatly by the magnitude and source of streamflow. During low streamflow conditions (less than $2,500 \mathrm{ft}^{3} / \mathrm{s}$ at DeSoto), the sources of streamflow are primarily ground water and reservoir

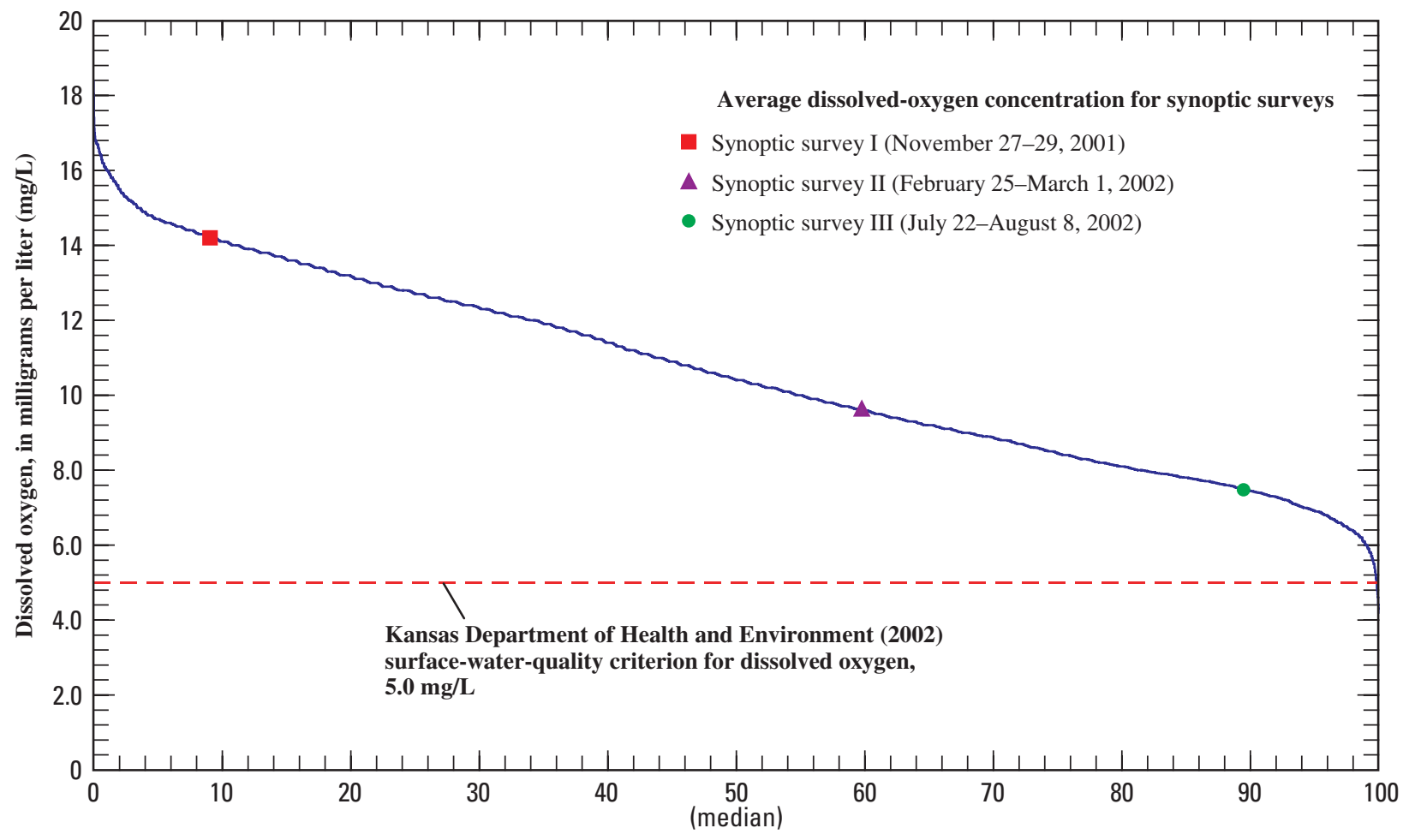

Percentage exceedance

Figure 15. Duration curve for dissolved-oxygen concentration in Kansas River at Topeka (station 06889000, fig. 2), 0 ctober 2000 through September 2003, and average dissolved-oxygen concentration for each synoptic survey. 
releases to major tributaries. In addition, point sources and tributary inflows can greatly affect water quality of the Kansas River during low streamflow conditions.

For the purpose of spatial comparison of samples along the Kansas River, steady-state conditions were assumed for each synoptic survey period. Steady-state condition for this report is defined as a time when the local physical and chemical properties of the river system do not vary. Specifically, the water quantity and quality of inputs to the river system are stable over the specified period. Statistics and loads for selected constituents were computed from the results of water-quality analyses of samples collected during the three synoptic surveys (Appendix 1 at the back of this report) and are presented in this section. Selected constituent loads were calculated by multiplying instantaneous streamflow (cubic feet per second) by the concentration (milligrams per liter) and by a conversion factor of 2.44 to convert the values to kilograms per day. Of particular concern to water managers in Kansas, and detailed in the following sections, are concentrations of chloride, total nitrogen and phosphorus, and ammonia, and fecal coliform bacteria densities.

\section{Chloride}

Chloride is considered conservative and not involved in processes of interaction or loss as it moves through the river system (Feth, 1981). Given its conservative nature, chloride generally is considered a good tracer and can be used to identify streamflow or ground-water inputs, measured and not measured. The comparison of measured chloride load and calculated cumulative chloride load on the main stem of the Kansas River evaluates how representative the sampling was of the actual water-quality conditions. Similar measured and calculated cumulative chloride loads indicate that the sampling scheme used was adequate for representing water-quality conditions. Differences between measured and calculated cumulative loads indicate inadequate sampling of some part of the river system (ground water, small tributary input, and so forth).

Water samples collected during synoptic survey I (November 27-29, 2001) and II (February 25-March 1, 2002) were analyzed for chloride concentrations. A total of 73 samples were analyzed; 30 samples were from tributaries, 28 were from Kansas River main-stem sites, and 15 were from WWTFs. The mean chloride concentration of the tributary samples was less than one-half the mean concentrations of the mainstem samples and the WWTF samples (table 5). None of the samples collected from the Kansas River had chloride concentrations greater than $250 \mathrm{mg} / \mathrm{L}$, the State of Kansas drinkingwater supply criterion for chloride (Kansas Department of Health and Environment, 2002).

Results indicated a slight decrease in concentration from upstream to downstream in the Kansas River (fig. 16). Mean concentrations of chloride during synoptic surveys I and II were largest in samples from WWTFs and smallest in samples from the tributaries (table 5). Chloride concentrations ranged from $4.9 \mathrm{mg} / \mathrm{L}$ in the Delaware River below Perry Dam (site 20) to $170 \mathrm{mg} / \mathrm{L}$ in the effluent of the North Topeka WWTF (site 11), Topeka Oakland WWTF (site 13), and Bonner Springs WWTF (site 39) (fig. 2; Appendix 1).

Measured and cumulative chloride loads for the sampling sites along the Kansas River were plotted so that a line indicating accumulated mass per river mile could be compared to measured mass at specific main-stem sites (fig. 17). If the assumptions that chloride is conservative and the river system is at steady state are correct, the calculated measured load at any given site should equal the accumulated load. In reaches unaffected by WWTF discharges, differences between accumulated and measured chloride load provide an indication of groundwater discharge or recharge.

Calculation of measured and cumulative chloride loads provided a check of the hydrodynamics of the river system. Only inflows from tributaries and ground-water and surfacewater interaction can affect the concentration of chloride at

Table 5. Statistical summary of chloride concentrations in samples collected from the Kansas River, northeast Kansas, its tributaries, and selected wastewater-treatment facility effluent for synoptic surveys I and II, November 27-29, 2001, and February 25-March 1, 2002.

[mg/L, milligram per liter $]$

\begin{tabular}{|c|c|c|c|c|c|c|}
\hline \multirow{2}{*}{ Statistic } & \multicolumn{2}{|c|}{$\begin{array}{c}\text { Kansas River main-stem } \\
\text { sampling sites }\end{array}$} & \multicolumn{2}{|c|}{ Tributary sampling sites } & \multicolumn{2}{|c|}{$\begin{array}{l}\text { Wastewater-treatment } \\
\text { facility sampling sites }\end{array}$} \\
\hline & $\begin{array}{l}\text { Synoptic } \\
\text { survey I }\end{array}$ & $\begin{array}{l}\text { Synoptic } \\
\text { survey II }\end{array}$ & $\begin{array}{l}\text { Synoptic } \\
\text { survey I }\end{array}$ & $\begin{array}{l}\text { Synoptic } \\
\text { survey II }\end{array}$ & $\begin{array}{l}\text { Synoptic } \\
\text { survey I }\end{array}$ & $\begin{array}{l}\text { Synoptic } \\
\text { survey II }\end{array}$ \\
\hline Number of samples & 5 & 23 & 12 & 18 & 7 & 8 \\
\hline Mean concentration (mg/L) & 89 & 109 & 41 & 39 & 119 & 139 \\
\hline Median concentration (mg/L) & 76 & 111 & 30 & 22 & 113 & 132 \\
\hline Range in concentrations (mg/L) & $73-117$ & $79-126$ & $5-95$ & $5-137$ & $74-167$ & $106-170$ \\
\hline $\begin{array}{l}\text { Number of values less than reporting level (0.02 } \\
\mathrm{mg} / \mathrm{L})\end{array}$ & 0 & 0 & 0 & 0 & 0 & 0 \\
\hline
\end{tabular}


A. Synoptic survey I, November 27-29, 2001

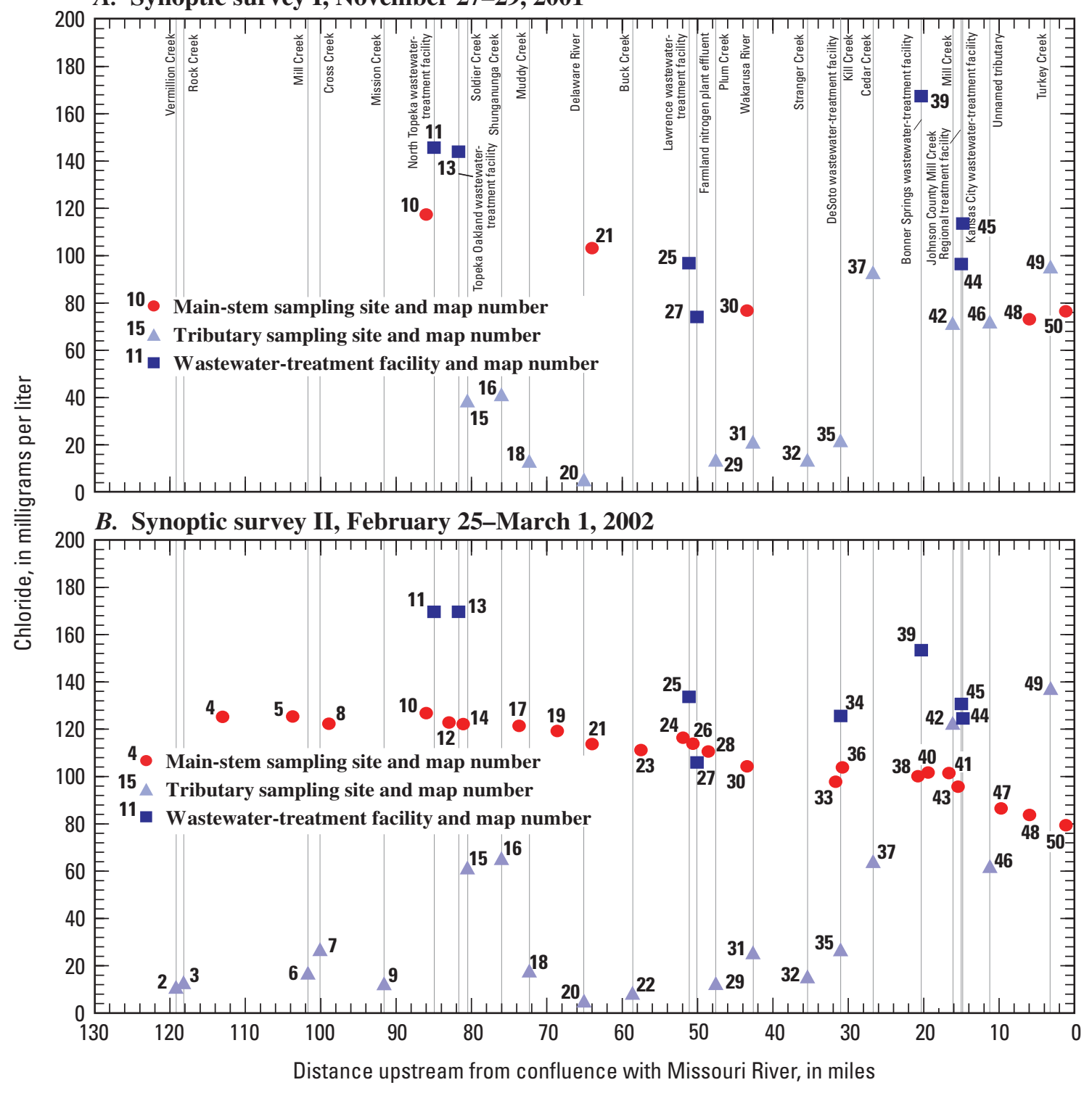

Figure 16. Chloride concentrations in samples collected from main-stem Kansas River, tributaries, and wastewater-treatment facility effluent for $(A)$ synoptic survey I and $(B)$ synoptic survey II. Location of sampling sites shown by map number in figure 2 .

various locations along the main-stem Kansas River. This was helpful in identifying and estimating ground-water inflow, which was not measured during the synoptic surveys.

Results of chloride load calculations for synoptic survey II (fig. 17) indicated that calculated measured loads of chloride in the Kansas River decreased from Topeka to Kansas City, and most notably between Lawrence and Kansas City. The decrease in chloride load indicated that chloride left the stream, possibly through the Kansas River streambed into the ground water in the Kansas River alluvium. Such a loss in chloride also would indicate a proportional loss in streamflow. However, streamflow increased along this reach (except between sites 30 and 33) (fig. 10) indicating the opposite effect. Calculation of measured chloride loads was complicated by the daily operation of
Bowersock Dam and the order in which the samples were collected, as discussed in the "Hydrologic Conditions" section of this report. The data collected during these two synoptic surveys were insufficient to explain the complexities of the river system with respect to chloride.

\section{Total Nitrogen and Phosphorus}

Nitrogen commonly occurs in natural water in several different forms including dissolved molecular nitrogen $\left(\mathrm{N}_{2}\right)$, organic compounds (amino acids, amines, proteins), ammonia [includes ammonia $\left(\mathrm{NH}_{3}\right)$ and ammonium $\left(\mathrm{NH}_{4}{ }^{+}\right)$ions], nitrite $\left(\mathrm{NO}_{2}{ }^{-}\right)$, and nitrate $\left(\mathrm{NO}_{3}{ }^{-}\right)$(Chapra, 1997). Sources of nitrogen include fixation of atmospheric molecular nitrogen by bacteria 
A. Synoptic survey I, November 27-29, 2001

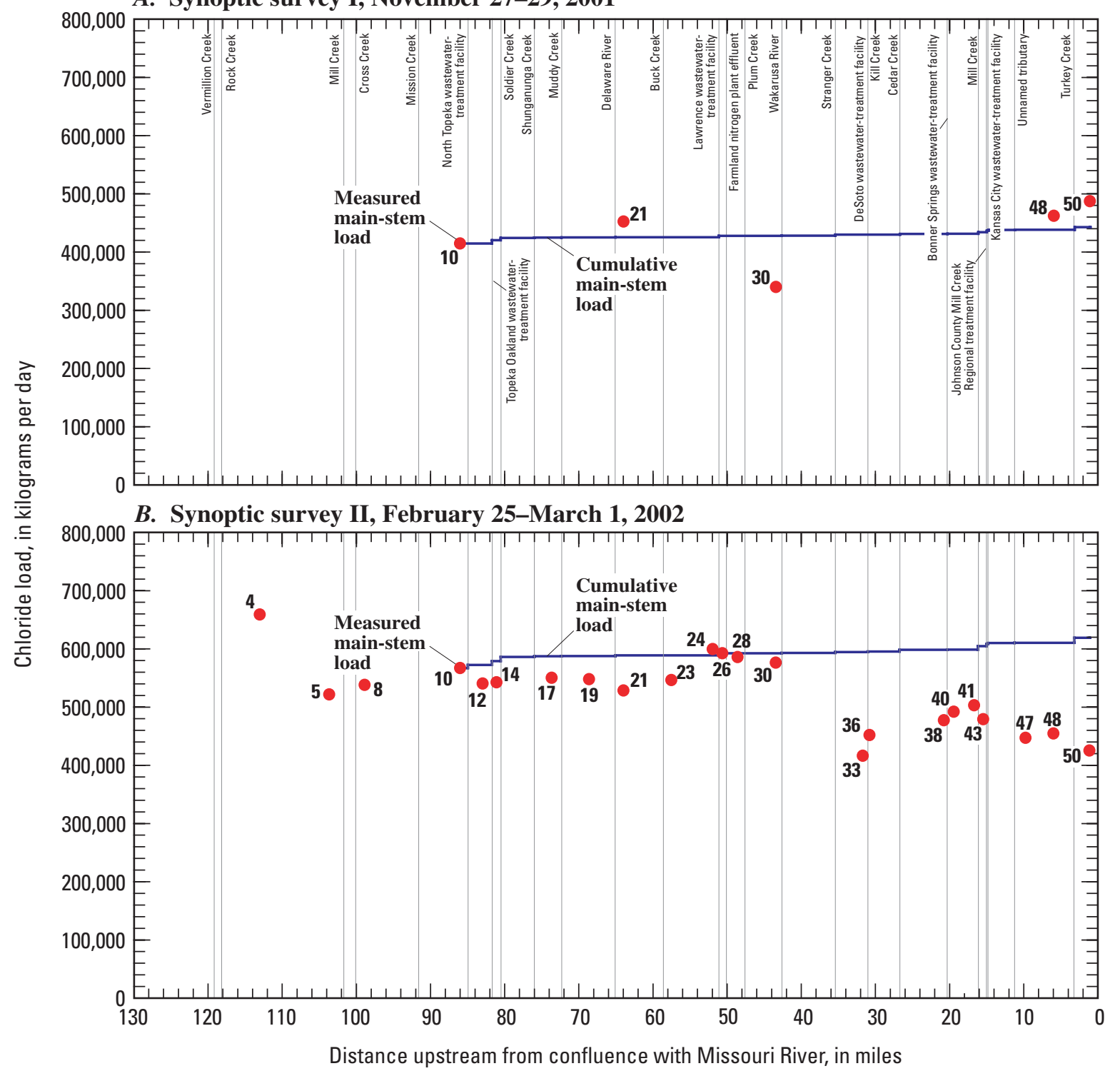

Figure 17. Calculated measured and cumulative chloride loads in Kansas River during $(A)$ synoptic survey I and $(B)$ synoptic survey II. Location of sampling sites shown by map number in figure 2 .

and algae, the decay of organic material such as algae or washed-in leaf material, animal wastes, improperly functioning septic systems, and urban runoff. Fertilizers applied to cropland provide both soluble nitrogen compounds, such as ammonium nitrate, and insoluble compounds, such as TKN (total Kjeldahl nitrogen, or total ammonia plus organic nitrogen). TKN is relatively immobile in soil because of its adsorption to soil surfaces. However, under oxygen-rich conditions, TKN can be converted to nitrite and nitrate and enter the ground- and surface-water systems (Horne and Goldman, 1994).

Nitrogen can be transformed from one form to another by a biologically catalyzed reaction. Bacteria and blue-green algae (cyanobacteria) can transform nitrogen gas to ammonia by an enzyme in a process known as nitrogen fixation (Horne and Goldman, 1994). Other bacteria catalyze the oxidation of ammonia to nitrite, then to nitrate by a process known as nitrification; the process occurs quickly in the oxygen-rich environments of most streams. Ammonia is the preferred form of algal uptake and is followed by nitrite and nitrate and then dissolved molecular nitrogen (Wetzel, 2001). Organisms can use these forms of nitrogen and incorporate the nitrogen into algal cells, which in turn decay and release nitrogen as ammonia. Currently (2005), there are no KDHE drinking-water or aquatic-life-support criteria for total nitrogen in Kansas. USEPA has recommended nutrient criteria for various ecoregions, spatially defined for the United States. Sampling sites for this study are located in ecoregions IV and IX and have recommended total nitrogen criteria of 0.56 and $0.69 \mathrm{mg} / \mathrm{L}$, respectively (U.S. Environmental Protection Agency, 2003). 
Phosphorus is a nutrient essential for the growth and reproduction of plants and animals. It is used as an energy source in the cells of plants and animals and can have a direct effect on the production of phytoplankton populations, an important component of the food chain. Phosphorus availability is often the limiting nutrient that controls biological production rates (Hem, 1992). Excessive phosphorus concentrations in soils from both natural and human-related sources can have detrimental effects on streams and lakes located downgradient from source areas and can promote excessive algal growth. Common sources of human-related phosphorus include inorganic phosphates added to agricultural soils as fertilizer, manure from confined animal-feeding operations, and treated wastewater discharged into receiving streams. Currently (2005), there are no established KDHE drinking-water criteria for total phosphorus; however, USEPA recommended criteria for total phosphorus in ecoregions IV and IX are 0.23 and $0.36 \mathrm{mg} / \mathrm{L}$, respectively

(U.S. Environmental Protection Agency, 2003).

Total nitrogen and phosphorus concentrations in the Kansas River were generally the same from upstream to downstream within the study area with some slight variation between sites (figs. 18 and 19). Slight increases in concentrations were measured at sites downstream from major point-source discharges (WWTFs). Concentrations of total nitrogen and phosphorus in samples collected from the main-stem Kansas River ranged from 1.1 to $2.6 \mathrm{mg} / \mathrm{L}$ and 0.19 to $2.0 \mathrm{mg} / \mathrm{L}$, respectively (tables 6 and 7).

The five main-stem samples for synoptic survey I indicated little variability in total nitrogen concentrations from upstream to downstream. Samples varied from $1.1 \mathrm{mg} / \mathrm{L}$ just upstream from Topeka (site 10) to $1.8 \mathrm{mg} / \mathrm{L}$ just downstream from Topeka (site 21), with a mean for the five samples of $1.5 \mathrm{mg} / \mathrm{L}$ (table 6).

Nitrogen concentrations during synoptic survey II and III indicated some effect from point sources but were still mostly stable. Concentrations in the 23 main-stem samples collected during synoptic survey II had a mean of $1.5 \mathrm{mg} / \mathrm{L}$ and varied from 1.2 to $1.9 \mathrm{mg} / \mathrm{L}$. Sample results from the third synoptic survey indicated the same spatial variability of nitrogen concentrations in the Kansas River. Multiple samples collected at selected sites during synoptic survey III indicated that daily nitrogen concentrations at a single site varied as much as 70 percent. Loads for total nitrogen and phosphorus were not calculated.

The five main-stem samples for synoptic survey I indicated little variability in total phosphorus concentrations from upstream to downstream (fig. 19A). Samples varied from $0.19 \mathrm{mg} / \mathrm{L}$ just upstream from Topeka (site 10) to $0.28 \mathrm{mg} / \mathrm{L}$ just downstream from Topeka (site 21), with a mean for the five samples of $0.25 \mathrm{mg} / \mathrm{L}$ (table 7).

Total phosphorus concentrations during synoptic survey II and III indicated some effect from point-sources discharges but were mostly uniform through the reach. Concentrations for the 18 main-stem samples collected during synoptic survey II had a mean of $0.26 \mathrm{mg} / \mathrm{L}$ and varied from 0.20 to $0.35 \mathrm{mg} / \mathrm{L}$ (table 7; fig. 19B). Sample results from the third synoptic survey indi- cated much greater spatial variability in phosphorus concentrations in the Kansas River (fig. 19C). Multiple samples collected at selected sites during synoptic survey III indicated that daily concentrations at a single site varied as much as one order of magnitude.

\section{Ammonia}

Ammonia is acutely toxic to freshwater organisms including fish and invertebrates at varying concentrations depending on the $\mathrm{pH}$ and temperature of the water (U.S. Environmental Protection Agency, 1986). The effects of acutely toxic ammonia concentrations on fishes are loss of equilibrium, increased breathing, convulsions, coma, and possibly death. At smaller concentrations, the effects of ammonia on fish include reduction in hatching success, reduction in growth rate, and pathologic changes in tissues of gills, livers, and kidneys.

In 1999, the U.S. Environmental Protection Agency (1999) introduced revised criteria for ammonia with respect to aquatic life. These criteria were split into acute and chronic criteria that are based on fish species, early life of fish present or absent, and water $\mathrm{pH}$ and temperature. The acute criteria for ammonia are based on water $\mathrm{pH}$ and are split into categories for the presence of salmonids (more stringent) and the absence of salmonids. The chronic criteria are $\mathrm{pH}$ and water-temperature dependent and are split into categories of fish, early life present (more stringent), and early life absent. The current (2005) ammonia criteria for Kansas (fig. 13) are identical to USEPA criteria, except there are no acute criteria for the presence of salmonids because Kansas does not have natural populations of salmonid species.

Ammonia concentrations in the Kansas River varied during the three synoptic surveys, with increases in concentration at sites downstream from major point sources (fig. 20). A total of 147 samples were analyzed for ammonia as nitrogen; more than one-half (76) were samples from Kansas River main-stem sites, one-third (8) were from tributaries, and 23 were from WWTFs (table 8). Ammonia concentrations in 25 samples from the Kansas River and 5 samples from tributaries were less than the laboratory reporting level of $0.02 \mathrm{mg} / \mathrm{L}$. For interpretation purposes, concentrations for these samples were assumed to be one-half the reporting level $(0.01 \mathrm{mg} / \mathrm{L})$. None of the samples collected from the Kansas River had ammonia concentrations greater than the State of Kansas $\mathrm{pH}$ - and temperature-dependent chronic aquatic-life criteria for ammonia with early-life stages present (Kansas Department of Health and Environment, 2002).

The five main-stem samples for synoptic survey I indicated ammonia concentrations increased an order of magnitude from Topeka (site 10) to the Delaware River (site 21) and then stabilized at about $0.10 \mathrm{mg} / \mathrm{L}$ to the confluence with the Missouri River (fig. 20A). Sample concentrations varied from $0.03 \mathrm{mg} / \mathrm{L}$ just upstream from Topeka (site 10) to $0.19 \mathrm{mg} / \mathrm{L}$ just downstream from the confluence with the Delaware River (site 21), with a mean for the five samples of $0.10 \mathrm{mg} / \mathrm{L}$ (table 8). 
A. Synoptic survey I, November 27-29, 2001

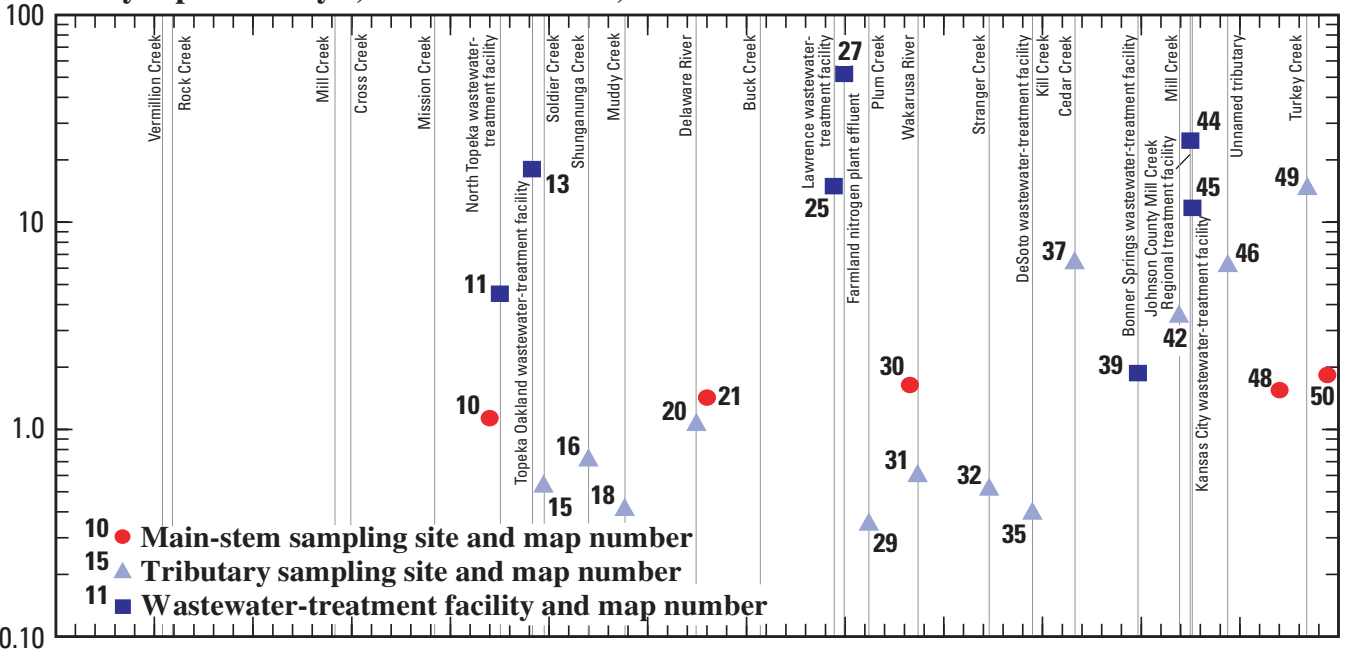

B. Synoptic survey II, February 25-March 1, 2002

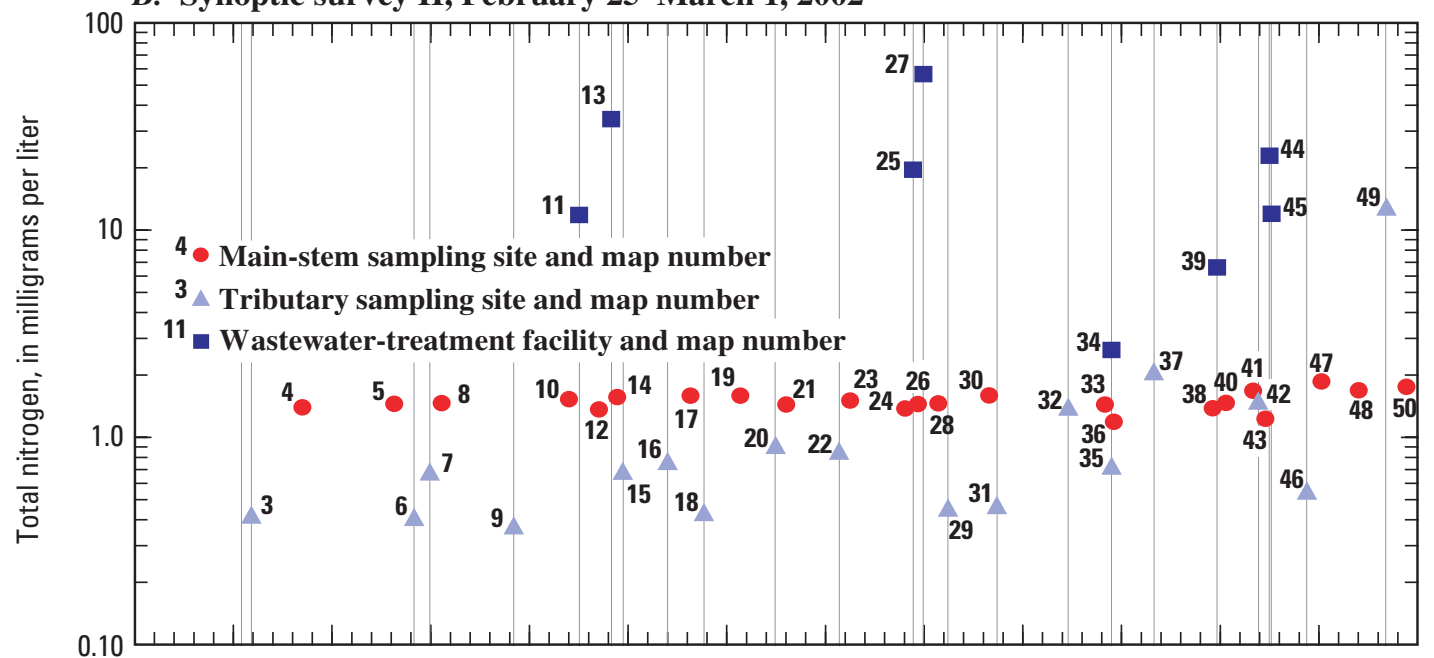

C. Synoptic survey III, July 22-August 8, 2002

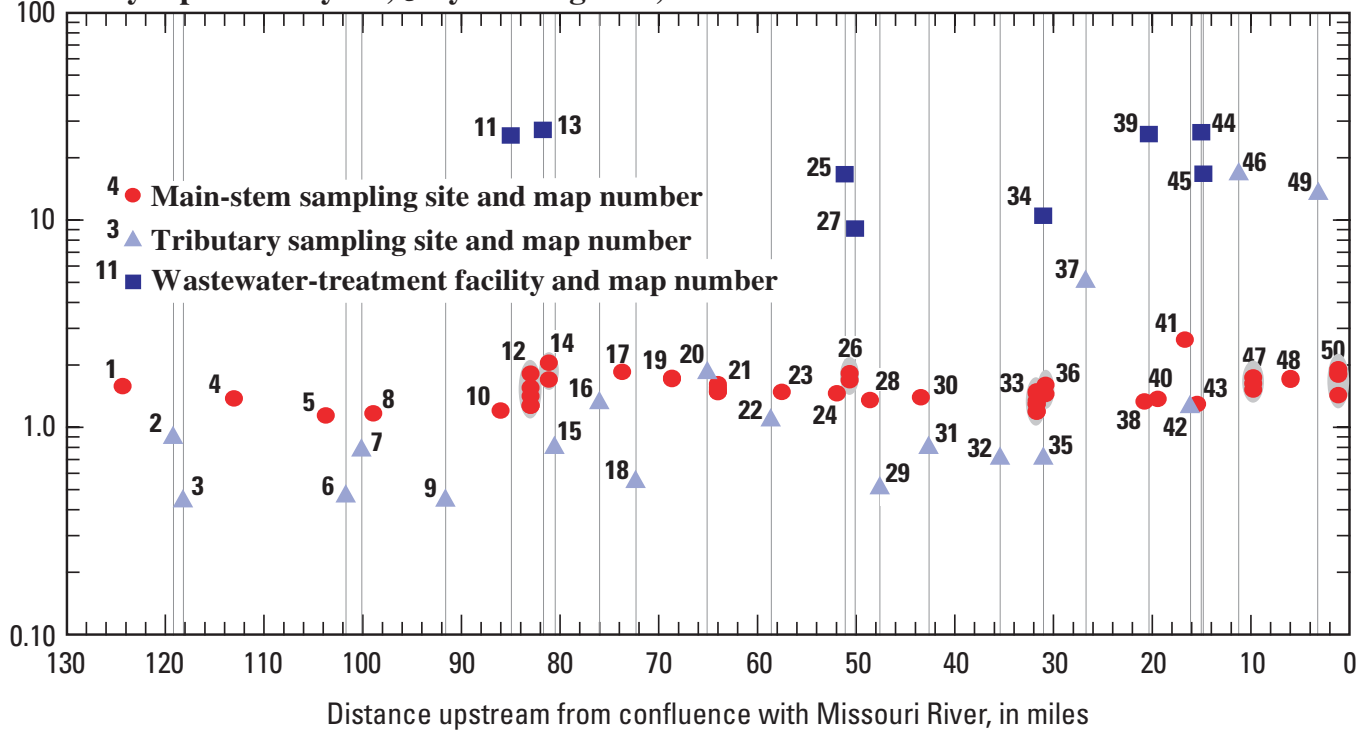

Figure 18. Concentrations of total nitrogen in samples collected from main-stem Kansas River, tributaries, and wastewater-treatment facility effluent for $(A)$ synoptic survey $\mathrm{I},(B)$ synoptic survey $\mathrm{II}$, and $(C)$ synoptic survey III. Location of sampling sites shown by map number in figure 2. Gray shading indicates multiple samples collected at a site. 
A. Synoptic survey I, November 27-29, 2001

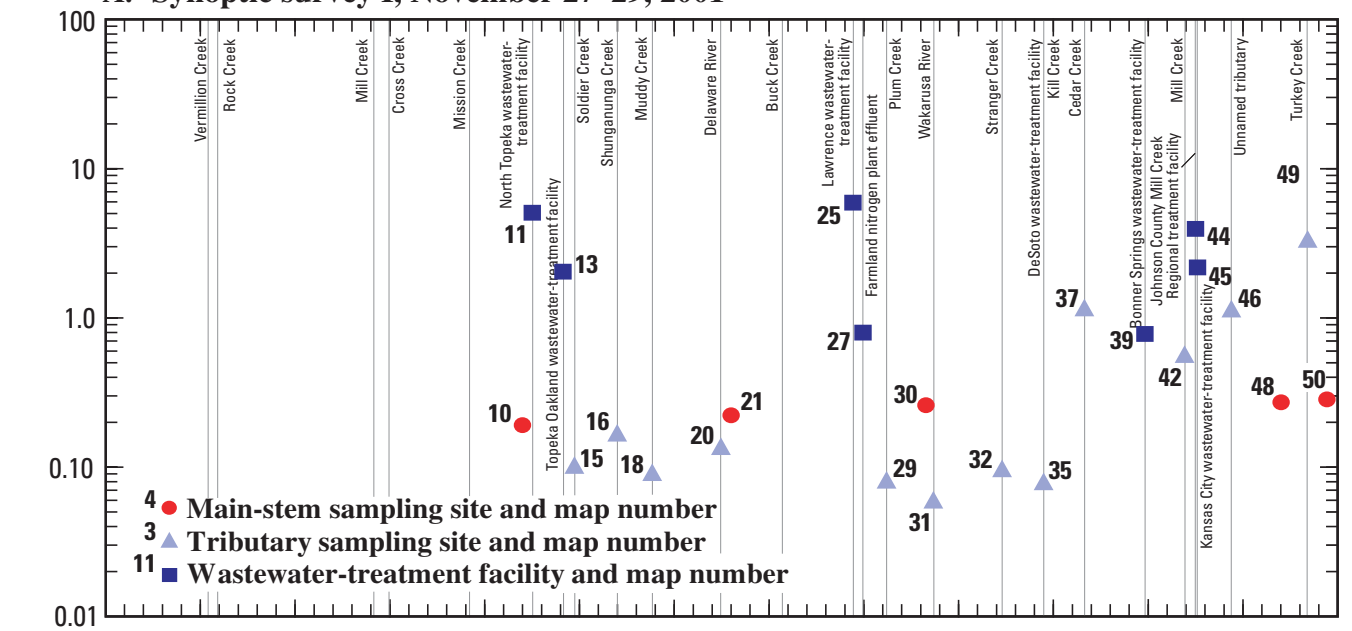

B. Synoptic survey II, February 25-March 1, 2002

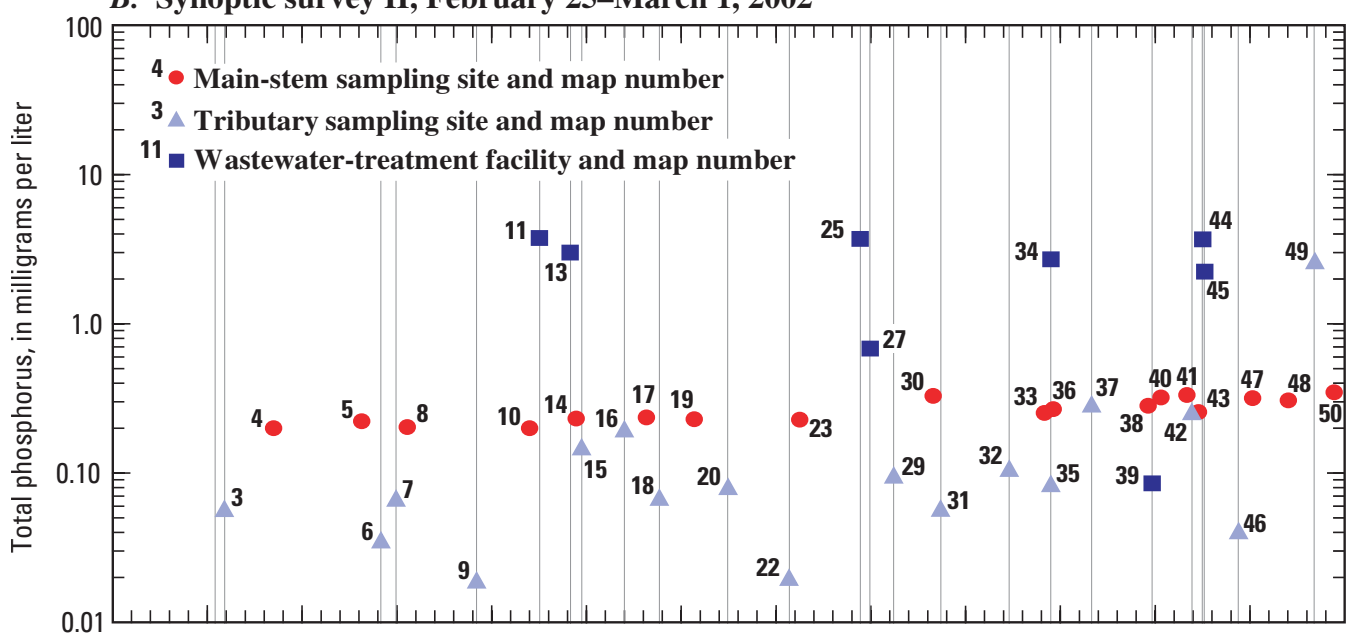

C. Synoptic survey III, July 22-August 8, 2002

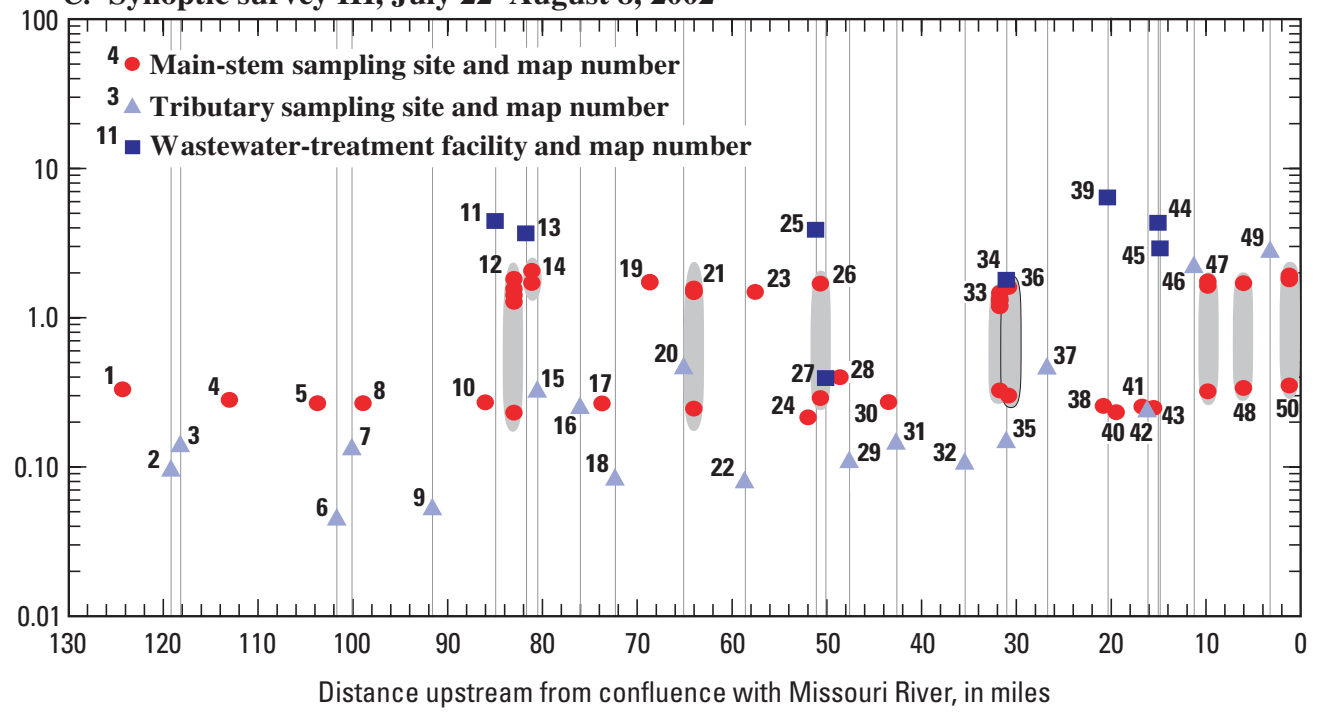

Figure 19. Concentrations of total phosphorus in samples collected from main-stem Kansas River, tributaries, and wastewater-treatment facility effluent for $(A)$ synoptic survey I, $(B)$ synoptic survey $\mathrm{II}$, and (C) synoptic survey III. Location of sampling sites shown by map number in figure 2. Gray shading indicates multiple samples collected at a site. 
Table 6. Statistical summary of total nitrogen concentrations in samples collected from the Kansas River, northeast Kansas, its tributaries, and selected wastewater-treatment facility effluent for synoptic surveys I, II, and III, November 2001-August 2002.

[mg/L, milligram per liter]

\begin{tabular}{|c|c|c|c|c|c|c|c|c|c|}
\hline \multirow{3}{*}{ Statistic } & \multicolumn{9}{|c|}{ Total nitrogen concentrations (mg/L) } \\
\hline & \multicolumn{3}{|c|}{$\begin{array}{c}\text { Kansas River main-stem sampling } \\
\text { sites }\end{array}$} & \multicolumn{3}{|c|}{ Tributary sampling sites } & \multicolumn{3}{|c|}{$\begin{array}{l}\text { Wastewater-treatment facility } \\
\text { sampling sites }\end{array}$} \\
\hline & $\begin{array}{l}\text { Synoptic } \\
\text { survey I }\end{array}$ & $\begin{array}{l}\text { Synoptic } \\
\text { survey II }\end{array}$ & $\begin{array}{l}\text { Synoptic } \\
\text { survey III }\end{array}$ & $\begin{array}{l}\text { Synoptic } \\
\text { survey I }\end{array}$ & $\begin{array}{l}\text { Synoptic } \\
\text { survey II }\end{array}$ & $\begin{array}{l}\text { Synoptic } \\
\text { survey III }\end{array}$ & $\begin{array}{l}\text { Synoptic } \\
\text { survey I }\end{array}$ & $\begin{array}{l}\text { Synoptic } \\
\text { survey II }\end{array}$ & $\begin{array}{l}\text { Synoptic } \\
\text { survey III }\end{array}$ \\
\hline Number of samples & 5 & 23 & 48 & 12 & 18 & 18 & 7 & 8 & 8 \\
\hline Mean concentration (mg/L) & 1.5 & 1.5 & 1.5 & 3.0 & 1.4 & 2.7 & 18 & 21 & 19.8 \\
\hline Median concentration (mg/L) & 1.5 & 1.5 & 1.5 & .67 & .07 & .80 & 15 & 16 & 21 \\
\hline Range in concentrations (mg/L) & $1.1-1.8$ & $1.2-1.9$ & $1.1-2.6$ & $0.36-15$ & $0.37-13$ & $0.45-17$ & $1.9-52$ & $2.6-57$ & $9.1-27$ \\
\hline
\end{tabular}

Table 7. Statistical summary of total phosphorus concentrations in samples collected from the Kansas River, northeast Kansas, its tributaries, and selected wastewater-treatment facility effluent for synoptic surveys I, II, and III, November 2001-August 2002.

[mg/L, milligrams per liter]

\begin{tabular}{|c|c|c|c|c|c|c|c|c|c|}
\hline \multirow{3}{*}{ Statistic } & \multicolumn{9}{|c|}{ Total phosphorus concentrations (mg/L) } \\
\hline & \multicolumn{3}{|c|}{$\begin{array}{l}\text { Kansas River main-stem sampling } \\
\text { sites }\end{array}$} & \multicolumn{3}{|c|}{ Tributary sampling sites } & \multicolumn{3}{|c|}{$\begin{array}{l}\text { Wastewater-treatment facility } \\
\text { sampling sites }\end{array}$} \\
\hline & $\begin{array}{l}\text { Synoptic } \\
\text { survey I }\end{array}$ & $\begin{array}{l}\text { Synoptic } \\
\text { survey II }\end{array}$ & $\begin{array}{l}\text { Synoptic } \\
\text { survey III }\end{array}$ & $\begin{array}{l}\text { Synoptic } \\
\text { survey I }\end{array}$ & $\begin{array}{l}\text { Synoptic } \\
\text { survey II }\end{array}$ & $\begin{array}{l}\text { Synoptic } \\
\text { survey III }\end{array}$ & $\begin{array}{l}\text { Synoptic } \\
\text { survey I }\end{array}$ & $\begin{array}{l}\text { Synoptic } \\
\text { survey II }\end{array}$ & $\begin{array}{l}\text { Synoptic } \\
\text { survey III }\end{array}$ \\
\hline Number of samples & 5 & 18 & 48 & 12 & 18 & 18 & 7 & 8 & 8 \\
\hline Mean concentration $(\mathrm{mg} / \mathrm{L})$ & .25 & .26 & 1.0 & .58 & .24 & .44 & 3.0 & 2.5 & 3.4 \\
\hline Median concentration (mg/L) & .26 & .02 & 1.3 & .12 & .07 & .14 & 2.2 & 2.8 & 3.8 \\
\hline Range in concentrations (mg/L) & $0.19-0.28$ & $0.20-0.35$ & $0.21-2.0$ & $0.06-3.3$ & $0.02-2.6$ & $0.05-2.8$ & $0.78-5.9$ & $0.09-3.8$ & $0.39-6.3$ \\
\hline
\end{tabular}

Ammonia concentrations during synoptic survey II clearly indicated effects from point sources (fig. 20B). Concentrations in the 23 main-stem Kansas River samples during synoptic survey II had a mean of $0.05 \mathrm{mg} / \mathrm{L}$ and varied from 0.02 to $0.16 \mathrm{mg} / \mathrm{L}$. Ammonia concentrations in the Kansas River from Belvue (site 4) to Topeka (site 10$)$ did not vary $(0.02 \mathrm{mg} / \mathrm{L}$, Appendix 1). Concentrations in main-stem samples at sites downstream from the Topeka Oakland WWTF (site 13) indicated about an order of magnitude increase $(0.10 \mathrm{mg} / \mathrm{L})$ for about $18 \mathrm{mi}$ to site 21 . Concentrations in samples from two main-stem sites just upstream from the Lawrence WWTF (sites 23 and 24) indicated a decrease in ammonia concentrations to $0.02 \mathrm{mg} / \mathrm{L}$. Immediately downstream from Lawrence (site 26), ammonia concentrations increased to $0.06 \mathrm{mg} / \mathrm{L}$ and then decreased to $0.02 \mathrm{mg} / \mathrm{L}$ at Bonner Springs (site 39). From Bonner Springs to the confluence with the Missouri River, ammonia concentrations varied from 0.02 to $0.03 \mathrm{mg} / \mathrm{L}$ depending on the location relative to upstream WWTFs (Appendix 1).

Sample results from the third synoptic survey indicated spatial and temporal variability of ammonia concentrations in the Kansas River (fig. 20C). Forty-eight samples were collected at 23 main-stem sites. Ammonia concentrations in 25 of the 48 main-stem samples were less than the reporting level.
Ammonia concentrations in samples from the main-stem sites ranged from less than 0.02 to $0.27 \mathrm{mg} / \mathrm{L}$, and the mean and median concentrations were 0.04 and less than $0.02 \mathrm{mg} / \mathrm{L}$, respectively (table 8).

Spatially, ammonia concentrations varied on the basis of sampling-site location in relation to upstream WWTFs. Generally, the nearer the sampling site was to an upstream WWTF, the larger the ammonia concentrations were. The maximum main-stem concentration $(0.27 \mathrm{mg} / \mathrm{L})$ was detected just downstream from the Topeka Oakland WWTF (site 14).

The temporal variability defined by the results of multiple samples collected at selected sites during synoptic survey III indicated that ammonia concentrations in the Kansas River varied hourly. Twelve pairs of samples were collected within a 24hour period at eight sampling sites on the main stem (Appendix 1 at the back of this report). Concentrations in 6 of the 12 sample pairs were less than the reporting level and, therefore, had no detectable difference. The mean percentage difference between the other six sample pairs was 94 percent, and differences ranged from 11 to 155 percent. Of the six sample pairs, no temporal pattern was evident. The results from these six sample pairs indicated that there was a measurable difference in ammonia concentration over a 24-hour period and 
A. Synoptic survey I, November 27-29, 2001

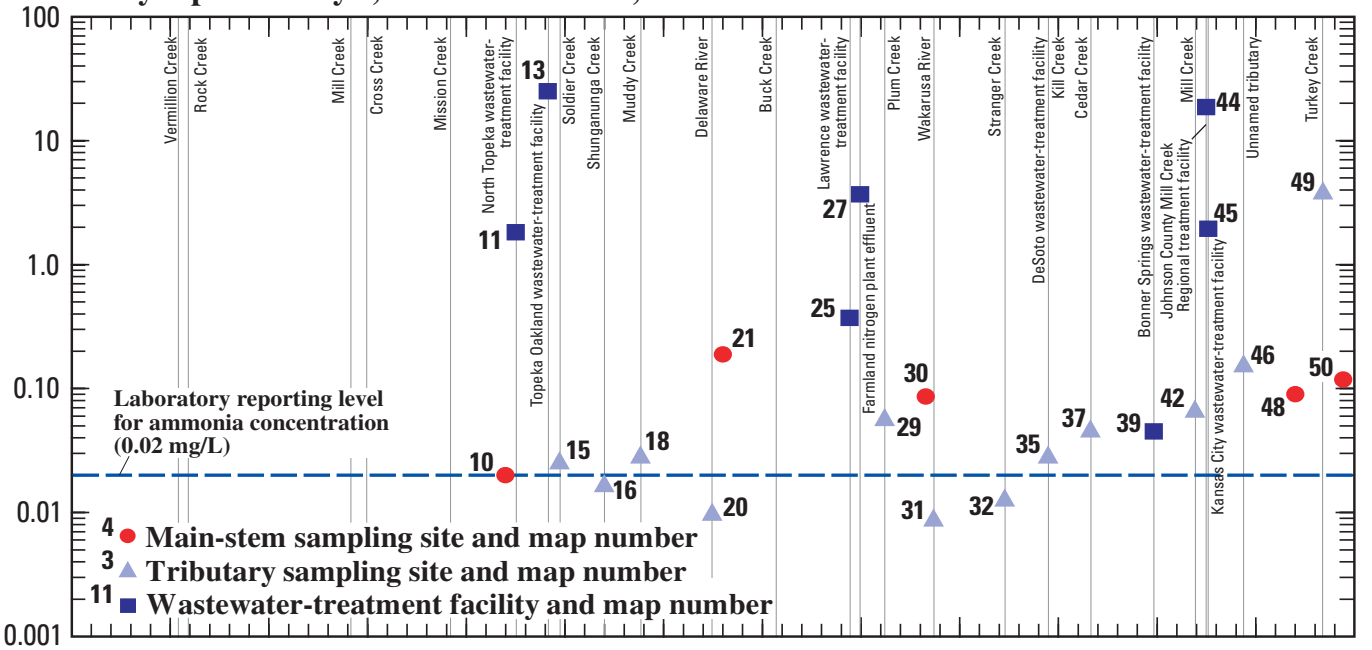

B. Synoptic survey II, February 25-March 1, 2002

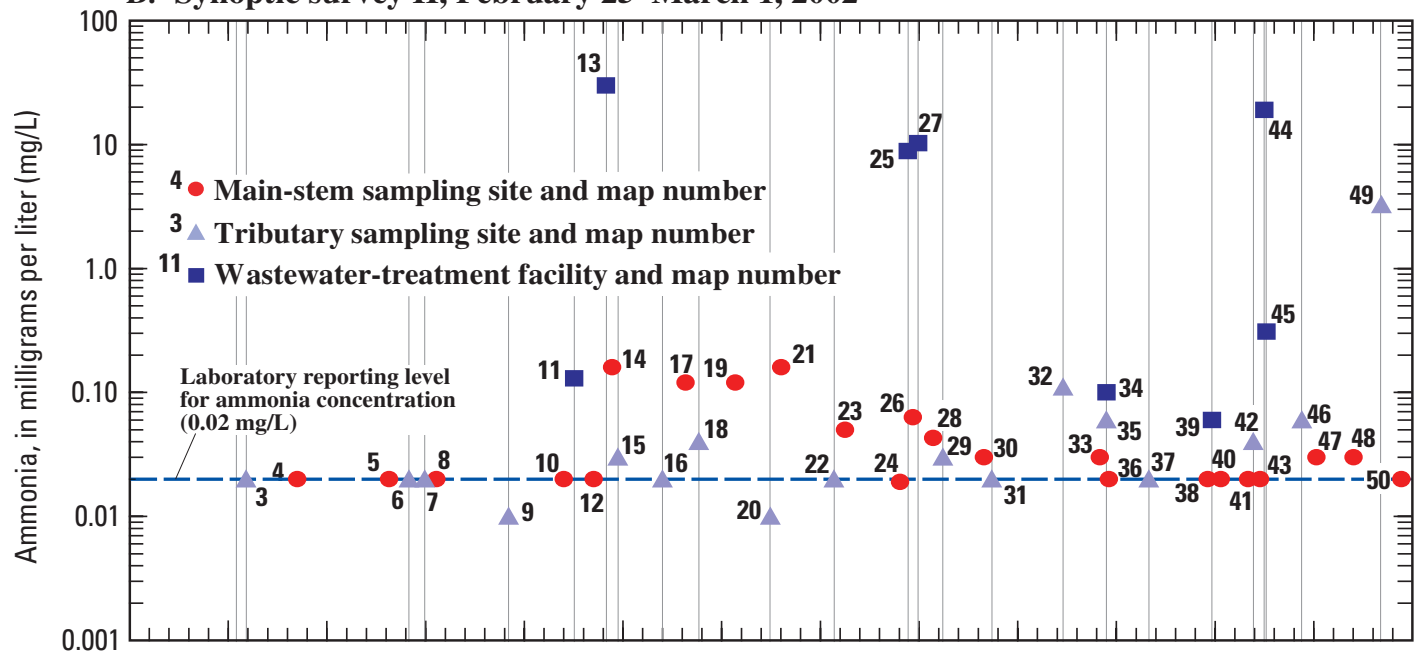

C. Synoptic survey III, July 22-August 8, 2002

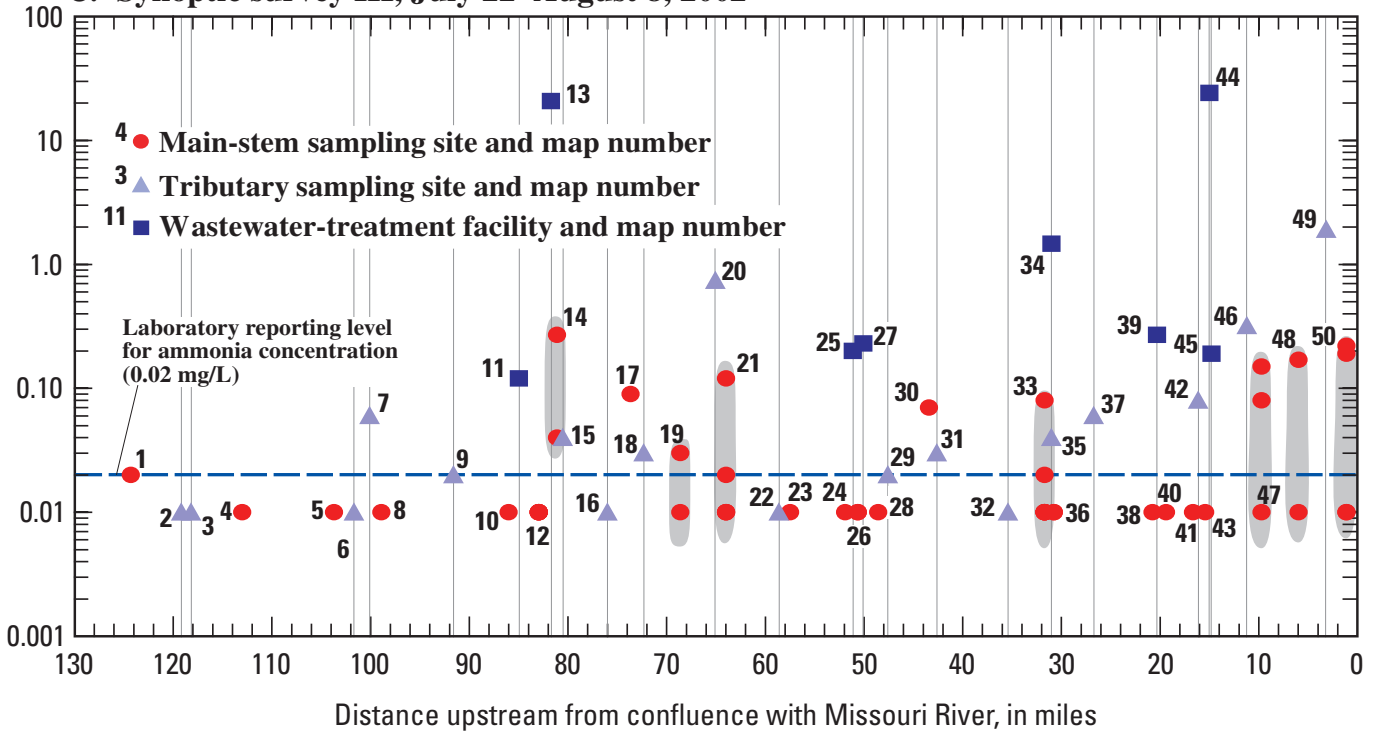

Figure 20. Concentrations of ammonia in samples collected from main-stem Kansas River, tributaries, and wastewater-treatment facility effluent for $(A)$ synoptic survey I, $(B)$ synoptic survey II, and (C) synoptic survey III. Location of sampling sites shown by map numbers in figure 2. Gray shading indicates multiple samples collected at a site. 
Table 8. Statistical summary of ammonia concentrations in samples collected from the Kansas River, northeast Kansas, its tributaries, and selected wastewater-treatment facility effluent for synoptic surveys I, II, and III, November 2001-August 2002.

[mg/L, milligrams per liter; <, less than]

\begin{tabular}{|c|c|c|c|c|c|c|c|c|c|}
\hline \multirow{3}{*}{ Statistic } & \multicolumn{9}{|c|}{ Ammonia concentrations (mg/L) } \\
\hline & \multicolumn{3}{|c|}{$\begin{array}{l}\text { Kansas River main-stem sampling } \\
\text { sites }\end{array}$} & \multicolumn{3}{|c|}{ Tributary sampling sites } & \multicolumn{3}{|c|}{$\begin{array}{l}\text { Wastewater-treatment facility } \\
\text { sample sites }\end{array}$} \\
\hline & $\begin{array}{l}\text { Synoptic } \\
\text { survey I }\end{array}$ & $\begin{array}{l}\text { Synoptic } \\
\text { survey II }\end{array}$ & $\begin{array}{l}\text { Synoptic } \\
\text { survey III }\end{array}$ & $\begin{array}{l}\text { Synoptic } \\
\text { survey I }\end{array}$ & $\begin{array}{l}\text { Synoptic } \\
\text { survey II }\end{array}$ & $\begin{array}{l}\text { Synoptic } \\
\text { survey III }\end{array}$ & $\begin{array}{l}\text { Synoptic } \\
\text { survey I }\end{array}$ & $\begin{array}{l}\text { Synoptic } \\
\text { survey II }\end{array}$ & $\begin{array}{l}\text { Synoptic } \\
\text { survey III }\end{array}$ \\
\hline Number of samples & 5 & 23 & 48 & 12 & 18 & 18 & 7 & 8 & 8 \\
\hline $\begin{array}{l}\text { Mean concentration } \\
(\mathrm{mg} / \mathrm{L})\end{array}$ & .10 & .05 & .04 & .36 & .21 & .19 & 7.4 & 8.6 & 5.9 \\
\hline $\begin{array}{l}\text { Median concentra- } \\
\text { tion }(\mathrm{mg} / \mathrm{L})\end{array}$ & .09 & .02 & $<.02$ & .03 & .02 & .03 & 1.9 & 4.6 & .25 \\
\hline $\begin{array}{l}\text { Range in concentra- } \\
\text { tions }(\mathrm{mg} / \mathrm{L})\end{array}$ & $0.03-0.19$ & $0.02-0.16$ & $<0.02-0.27$ & $0.01-3.9$ & $<0.02-3.3$ & $<0.02-1.9$ & $0.04-25$ & $0.06-30$ & $0.12-24$ \\
\hline $\begin{array}{l}\text { Number of values less } \\
\text { than laboratory } \\
\text { reporting level } \\
(0.02 \mathrm{mg} / \mathrm{L})\end{array}$ & 0 & 0 & 32 & 0 & 1 & 4 & 0 & 0 & 0 \\
\hline
\end{tabular}

that the difference can be quite large. Variations could be due to varying WWTF flow and (or) variations in water temperature and dissolved-oxygen concentrations affecting ammonia assimilation.

All samples collected at WWTFs or on tributaries downstream from WWTFs had ammonia concentrations that varied from less than 0.02 to $30 \mathrm{mg} / \mathrm{L}$ (table 8). For all three synoptic surveys, samples from the Topeka Oakland WWTF (site 13) and the Johnson County Mill Creek WWTF (site 44) had the largest ammonia concentrations of all the WWTFs. Mean ammonia concentrations for WWTFs were 74 to 172 times larger than the mean ammonia concentrations for the main-stem sites (table 8).

The "half-life," or assimilation rate, for ammonia was determine on the basis of decreasing ammonia concentrations for three segments of the Kansas River between major WWTF discharges. The concentrations for samples collected between the Topeka Oakland and Lawrence WWTFs (sites 14 to 26), Lawrence and DeSoto WWTFs (sites 26 to 47), and Johnson County Mill Creek WWTF and the confluence of the Kansas River with the Missouri River (sites 47 to 50) were fitted with exponential equation 2 .

$$
C_{d}=C_{o} \times e^{-k d}
$$

where $C_{d}$ is the concentration of ammonia at some distance, $d$, downstream from the concentrations $C_{O}$, in milligrams per liter;

$d \quad$ is the distance from the location where concentration $C_{o}$ was measured to the downstream location of the desired concentration $C_{d}$, in miles;
$C_{o}$ is the initial concentration of ammonia at distance, $d$, upstream from $C_{d}$, in milligrams per liter;

$e \quad$ is the base of natural logarithms; and

$k \quad$ is the exponential rate of decrease of ammonia concentration, in miles ${ }^{-1}$.

The exponent $(k)$ from this relation then was used in equation 3 to determine the distance required for the ammonia concentration in the Kansas River to equal one-half the initial concentration just downstream from the WWTF.

$$
\text { Half-life distance }=\frac{\ln (k)}{k} .
$$

Decreases in ammonia in the Kansas River are due primarily to nitrification and consumption by aquatic organisms by photosynthesis. During synoptic survey II, ammonia concentrations measured at various sites downstream from the Topeka Oakland WWTF (site 14), Lawrence WWTF (site 26), and Johnson County Mill Creek WWTF (site 47) indicated that the distances necessary to assimilate one-half of the initial ammonia concentration were 12, 20, and 28 miles, respectively (table 9). The increase in distances from up- to downstream indicated the Kansas River's decreasing assimilative capacity for ammonia. It should be noted that these distances only apply to the conditions observed during synoptic survey II.

The variability of the ammonia concentrations measured in the main stem during synoptic survey III was such that an exponential curve could not be fitted to the data. This was most difficult at main-stem sites where multiple samples were collected and the differences in concentrations were so great that there was no reasonable exponential fit. For this reason, decay rates were calculated only for the river segment between the 
Table 9. Estimated rates of ammonia decay in the Kansas River, northeast Kansas, during winter, February 25-March 1, 2002, and summer, July 22-August 8, 2002.

$\left[\mathrm{ft}^{3} / \mathrm{s}\right.$, cubic feet per second; --, not determined]

\begin{tabular}{|c|c|c|c|c|c|c|}
\hline \multirow[b]{2}{*}{$\begin{array}{l}\text { River segment between } \\
\text { sampling sites (fig. 2) }\end{array}$} & \multicolumn{3}{|c|}{ Synoptic survey II (winter) } & \multicolumn{3}{|c|}{ Synoptic survey III (summer) } \\
\hline & $\begin{array}{l}\text { Exponential rate } \\
\text { of decrease of } \\
\text { ammonia } \\
\text { concentration, } \mathrm{k} \\
\text { (miles }^{-1} \text { ) }\end{array}$ & $\begin{array}{c}\text { Distance } \\
\text { required to } \\
\text { assimilate one- } \\
\text { half ammonia } \\
\text { concentration } \\
\text { at } 1,900 \mathrm{ft}^{3} / \mathrm{s} \\
\text { (miles) }\end{array}$ & $\begin{array}{l}\text { Time required to } \\
\text { assimilate one- } \\
\text { half ammonia } \\
\text { concentrations at } \\
1,900 \mathrm{ft}^{3} / \mathrm{s} \\
\text { (hours) }\end{array}$ & $\begin{array}{l}\text { Exponential rate } \\
\text { of decrease of } \\
\text { ammonia } \\
\text { concentration, } \mathrm{k} \\
\text { (miles }^{-1} \text { ) }\end{array}$ & $\begin{array}{c}\text { Distance } \\
\text { required to } \\
\text { assimilate one- } \\
\text { half ammonia } \\
\text { concentrations } \\
\text { at } 1,900 \mathrm{ft}^{3} / \mathrm{s} \\
\text { (miles) }\end{array}$ & $\begin{array}{l}\text { Time required to } \\
\text { assimilate one- } \\
\text { half ammonia } \\
\text { concentrations at } \\
1,900 \mathrm{ft}^{3} / \mathrm{s} \\
\text { (hours) }\end{array}$ \\
\hline Sites 14-26 & 0.0642 & 12 & 7.8 & 0.1151 & 6 & 3.9 \\
\hline Sites $26-47$ & .0317 & 20 & 12 & -- & -- & -- \\
\hline Sites $47-50$ & .0280 & 28 & 12 & -- & -- & -- \\
\hline
\end{tabular}

Topeka Oakland and Lawrence WWTFs. The rate of decrease in ammonia concentration for this reach was the largest of all, indicating that the assimilative capacity of the Kansas River is greater during the summer.

Comparison of calculated measured and cumulative ammonia loads indicated that ammonia loads in the Kansas River varied greatly between Topeka and Kansas City (fig. 21). The largest loads of ammonia measured in the main-stem Kansas River during synoptic survey II were just downstream from the Topeka Oakland WWTF (site 14). Measured ammonia loads were smallest at main-stem sites upstream from Topeka. Inputs of ammonia from the major WWTFs during synoptic survey III were smaller than the inputs during synoptic survey II, with the exception of the Johnson County WWTFs. Measured loads of ammonia during synoptic survey II in the Kansas River downstream from river mile 64 (distance upstream from confluence with Missouri River) were relatively small despite large inputs of ammonia from the Johnson County Mill Creek (site 44) and Johnson County Nelson WWTFs just upstream from sampling site 49 (640 and $105 \mathrm{~kg} / \mathrm{d}$, respectively). Large variability in loads of ammonia (ranging from 24 to $680 \mathrm{~kg} / \mathrm{d}$ ) were measured during synoptic survey III along the final $10 \mathrm{mi}$ of the Kansas River just upstream from the confluence with the Missouri River.

\section{Fecal Coliform Bacteria}

Fecal coliform bacteria densities were measured in the Kansas River watershed and varied between two and three orders of magnitude during the three synoptic surveys, with increases in densities at sites downstream from major WWTFs (fig. 22). A total of 141 samples were analyzed for fecal coliform bacteria; 71 were samples from Kansas River mainstem sites, and 70 were from tributaries and WWTFs (table 10). Fecal coliform densities in these samples ranged from less than 1 to $290,000 \mathrm{col} / 100 \mathrm{~mL}$. Densities for samples with values less than $1 \mathrm{col} / 100 \mathrm{~mL}$ were assumed to be $1 \mathrm{col} / 100 \mathrm{~mL}$. One of the main-stem samples, three of the tributary samples, and seven of the WWTF samples had fecal coliform bacteria densities greater than the former (2002) State of Kansas single-sample secondary contact recreational criterion of 2,000 col/100 mL (Kansas Department of Health and Environment, 2002).

The five main-stem samples for synoptic survey I indicated varying bacteria densities from upstream to downstream (fig. 22A). Densities varied from $45 \mathrm{col} / 100 \mathrm{~mL}$ at Eudora (site 30 ) to $1,000 \mathrm{col} / 100 \mathrm{~mL}$ near Kansas City (site 48), with a mean density for the five samples of $260 \mathrm{col} / 100 \mathrm{~mL}$ (table 10).

Fecal coliform bacteria densities in samples from the Kansas River watershed during synoptic survey II were generally less than the densities detected in synoptic survey I samples and indicated some variability between sites (fig. 22B). Densities in the 23 main-stem samples had a mean of $26 \mathrm{col} / 100 \mathrm{~mL}$ and varied from less than 1 to $250 \mathrm{col} / 100 \mathrm{~mL}$ (table 10). Fecal coliform bacteria densities in main-stem samples from the Belvue (site 4) to Lawrence (site 26) sampling sites were fairly stable, between less than 1 and $16 \mathrm{col} / 100 \mathrm{~mL}$. Densities from samples collected downstream from Lawrence WWTF (site 28) and at Eudora (site 30) indicated about a two-order-of-magnitude increase to $250 \mathrm{col} / 100 \mathrm{~mL}$. Main-stem samples from the remaining sites downstream from Eudora had fecal coliform densities that varied between 8 and $60 \mathrm{col} / 100 \mathrm{~mL}$.

Sample results from the third synoptic survey indicated spatial and temporal variability and the effect of point-source discharges on fecal coliform bacteria densities in the Kansas River (fig. 22C). Forty-three samples were collected at 18 mainstem sites with fecal coliform bacteria densities ranging from 5 to $4,000 \mathrm{col} / 100 \mathrm{~mL}$ (table 10 ). The mean and median densities in the main-stem samples were 190 and $32 \mathrm{col} / 100 \mathrm{~mL}$, respectively. Spatially, fecal coliform bacteria densities varied on the basis of sampling-site location in relation to upstream WWTFs. Generally, the closer the sampling site was to an upstream WWTF, the larger the densities were. Two of the largest densities occurred downstream from the Topeka Oakland WWTF (site 14) and downstream from the Lawrence WWTF (site 30). A density of 4,000 col/100 mL occurred in a sample from the downstream-most Kansas River site (site 50). 
A. Synoptic survey I, November 27-29, 2001

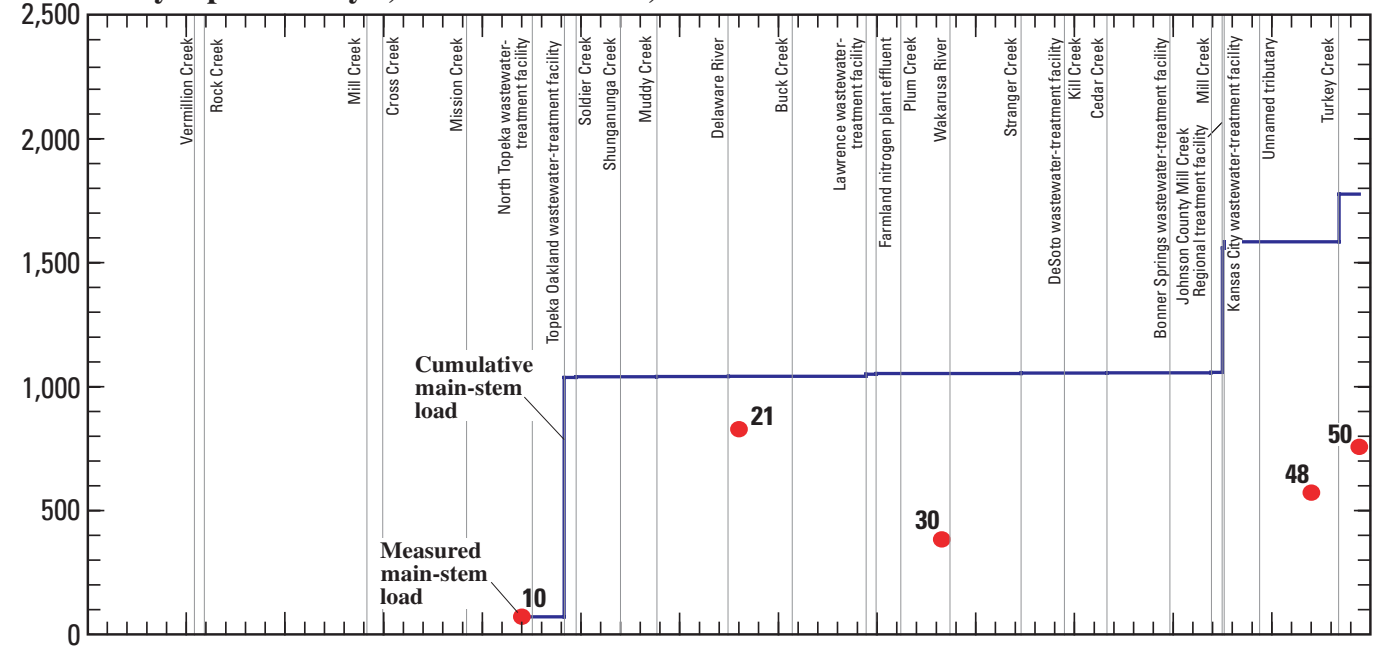

B. Synoptic survey II, February 25-March 1, 2002

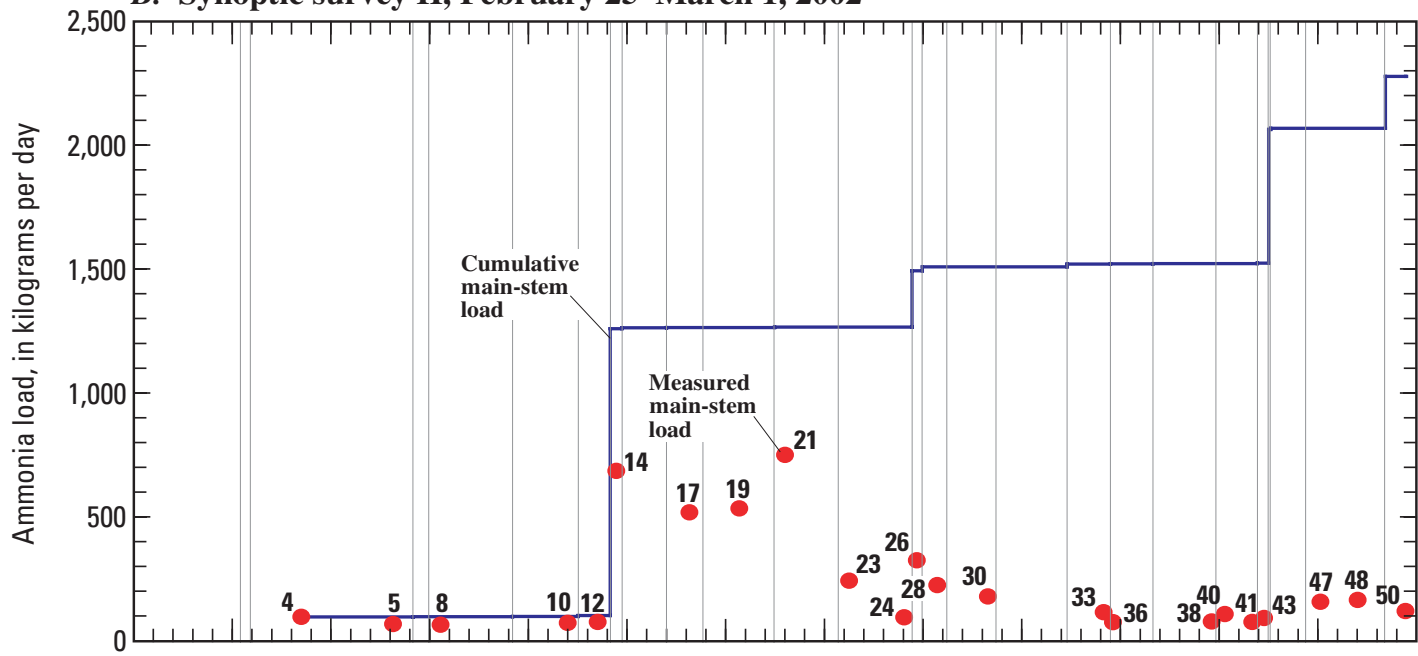

C. Synoptic survey III, July 22-August 8, 2002

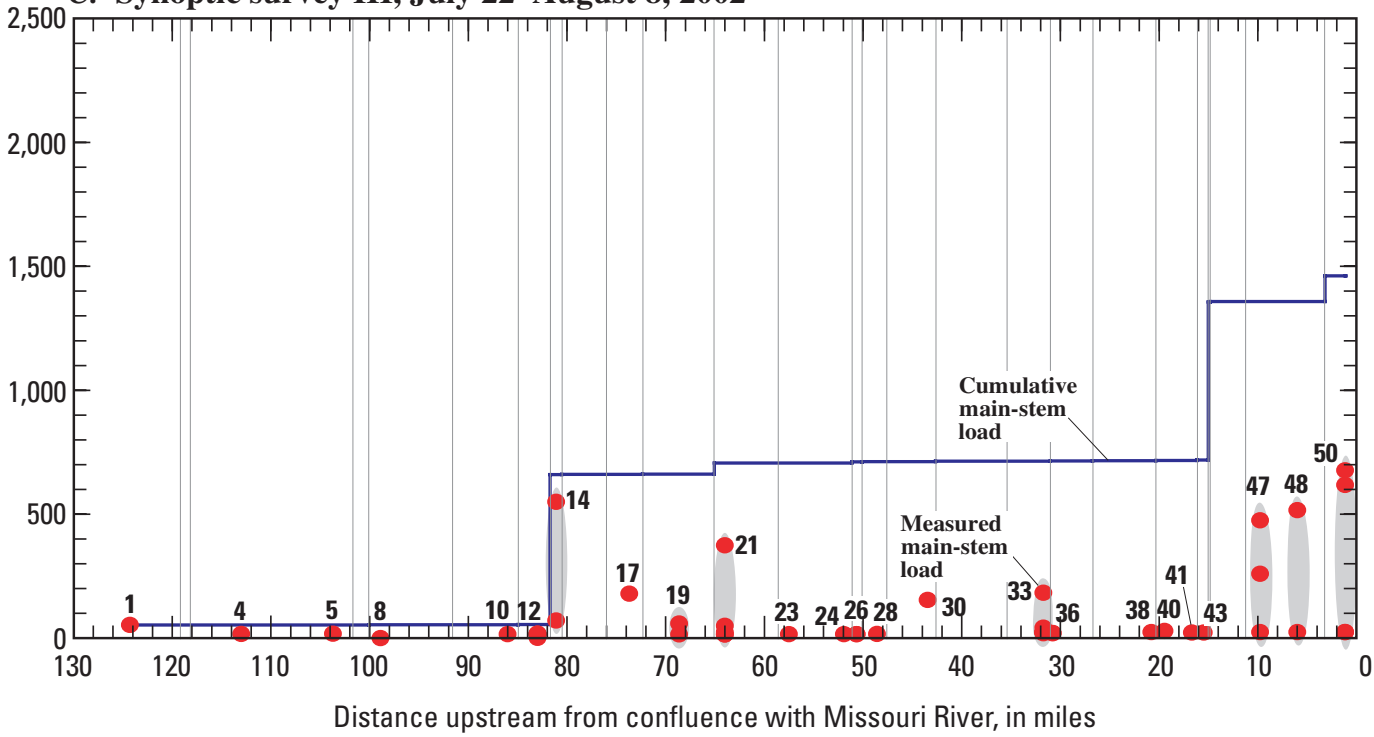

Figure 21. Calculated measured and cumulative ammonia loads in Kansas River during (A) synoptic survey I, $(B)$ synoptic survey II, and (C) synoptic survey III. Location of sampling sites shown by map number in figure 2. Gray shading indicates multiple samples collected at a site. 
A. Synoptic survey I, November 27-29, 2001
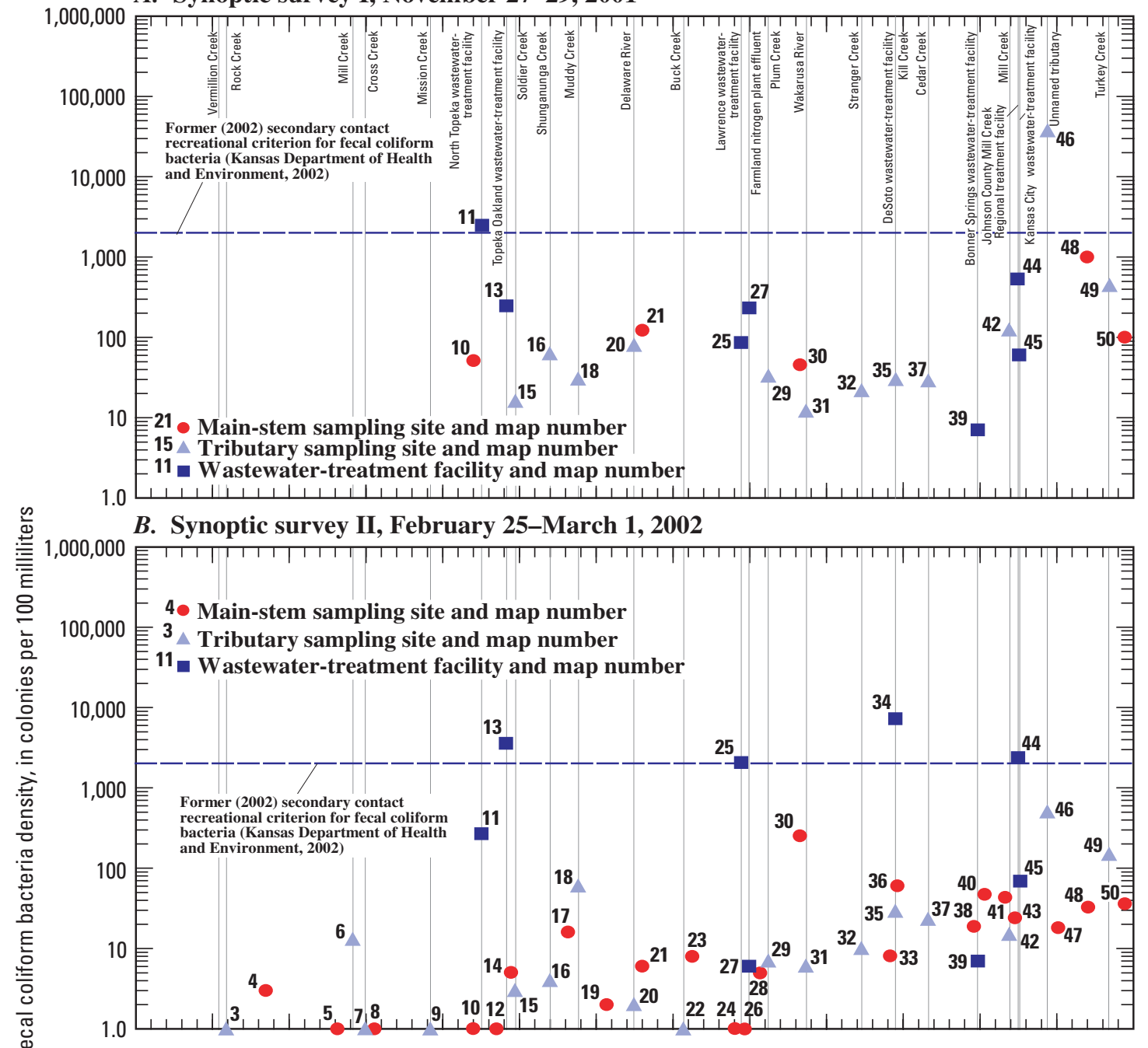

$\stackrel{\varpi}{\Psi}$ C. Synoptic survey III, July 22-August 8, 2002

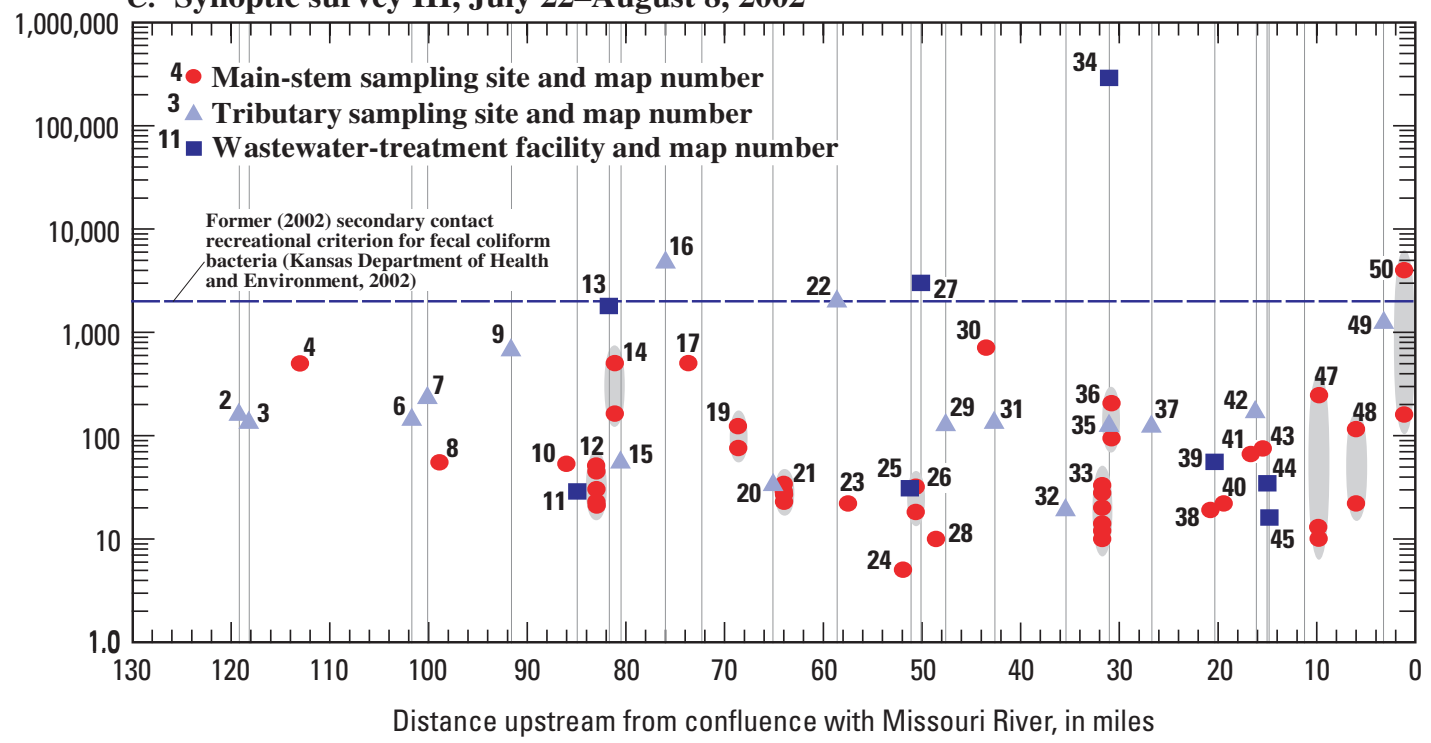

Figure 22. Fecal coliform bacteria densities in samples collected from main-stem Kansas River, tributaries, and wastewater-treatment facility effluent for $(A)$ synoptic survey $I,(B)$ synoptic survey II, and $(C)$ synoptic survey III. Location of sampling sites shown by map number in figure 2. Gray shading indicates multiple samples collected at a site. 
Table 10. Statistical summary of fecal coliform densities in samples collected from the Kansas River, northeast Kansas, its tributaries, and selected wastewater-treatment facility effluent for synoptic surveys I, II, and III, November 2001-August 2002.

[col/100 mL, colonies per 100 milliliters of water; <, less than]

\begin{tabular}{|c|c|c|c|c|c|c|c|c|c|}
\hline \multirow{2}{*}{ Statistic } & \multicolumn{3}{|c|}{$\begin{array}{c}\text { Kansas River main-stem sampling } \\
\text { sites }\end{array}$} & \multicolumn{3}{|c|}{ Tributary sampling sites } & \multicolumn{3}{|c|}{$\begin{array}{c}\text { Wastewater-treatment facility } \\
\text { sampling sites }\end{array}$} \\
\hline & $\begin{array}{l}\text { Synoptic } \\
\text { survey I }\end{array}$ & $\begin{array}{l}\text { Synoptic } \\
\text { survey II }\end{array}$ & $\begin{array}{l}\text { Synoptic } \\
\text { survey III }\end{array}$ & $\begin{array}{l}\text { Synoptic } \\
\text { survey I }\end{array}$ & $\begin{array}{l}\text { Synoptic } \\
\text { survey II }\end{array}$ & $\begin{array}{l}\text { Synoptic } \\
\text { survey III }\end{array}$ & $\begin{array}{l}\text { Synoptic } \\
\text { survey I }\end{array}$ & $\begin{array}{l}\text { Synoptic } \\
\text { survey II }\end{array}$ & $\begin{array}{l}\text { Synoptic } \\
\text { survey III }\end{array}$ \\
\hline Number of samples & 5 & 23 & 43 & 12 & 18 & 17 & 7 & 8 & 8 \\
\hline Mean density (col/100 mL) & 260 & 26 & 190 & 3,200 & 46 & 620 & 520 & 2,000 & 37,000 \\
\hline
\end{tabular}

Multiple samples were collected at 10 main-stem sites to assess temporal variance in fecal coliform bacteria densities during low streamflow conditions; two samples, respectively, were collected at 6 of the 10 sites, and 3, 4, 5, and 7 samples, respectively, were collected at each of the remaining four mainstem sites. The percentage differences between densities detected at each site ranged from 39 percent at Lecompton (site 21) to 263 percent at Kansas City (site 47). These samples indicated how great the variability of bacteria densities was during low streamflow conditions.

Decay of fecal coliform bacteria in the Kansas River was not as evident as the ammonia decay. During synoptic survey II, first-order decay rates (from equations 2 and 3 ) indicated that downstream from the Topeka Oakland WWTF (site 13) there was some decay, whereas densities downstream from the Lawrence (site 25) and Johnson County Mill Creek WWTFs (site 44) indicated no decay. The amount of fecal coliform bacteria being discharged from the Topeka Oakland, Lawrence, and Johnson County Mill Creek WWTFs was much smaller during synoptic survey III. The decay rate calculated for the densities downstream from the Topeka Oakland WWTF indicated some decay. Densities measured downstream from the Lawrence and Johnson County Mill Creek WWTFs indicated no decay.

Comparison of calculated measured and cumulative loads of fecal coliform bacteria for all three synoptic surveys varied greatly between Topeka and Kansas City (fig. 23). Measured loads of fecal coliform bacteria in the Kansas River displayed variability similar to that shown in the density plots. Large loads of fecal coliform were computed for samples collected during synoptic survey I and III along the final $10 \mathrm{mi}$ of the Kansas River just upstream from the confluence with the Missouri River. Loads of fecal coliform contributed by WWTFs during synoptic survey I were small relative to the other two synoptic surveys. The Topeka Oakland WWTF (site 13) and DeSoto
WWTF (site 34) discharged the largest loads into the Kansas River during synoptic surveys II and III, respectively.

\section{Discussion of Water-Quality Conditions During Low Flow}

The results from the three synoptic surveys indicated that concentrations of nutrients (total nitrogen and phosphorus and ammonia) and densities of fecal coliform bacteria during low streamflow conditions varied spatially and temporally and increased downstream from major point-source discharges (WWTFs). Concentrations and densities were relatively small at the sampling sites upstream from Topeka. Variability of concentrations and densities were largest from Topeka to the confluence with the Missouri River where WWTFs had a substantial effect on in-stream water quality. Assimilative processes typically reduced ammonia concentrations at distances downstream from the WWTFs and were about twice as effective during the summer synoptic survey (survey III) as during the winter synoptic survey (survey II). Decay of fecal coliform bacteria density was less evident and appeared to have little seasonal effect.

None of the ammonia concentrations in main-stem samples were greater than the $\mathrm{pH}$ - and temperature-dependent State of Kansas criteria for aquatic-life-support (Kansas Department of Health and Environment, 2002). However, two measurements of dissolved oxygen at sampling site 50 were less than the State's aquatic-life-support use criterion $(5.0 \mathrm{mg} / \mathrm{L})$ during the summer. Low streamflow water-quality conditions in the summer were more suitable for nitrification and algae, which consumed the oxygen. Therefore, the more ammonia that was available during these conditions, the more dissolved oxygen was consumed. 
A. Synoptic survey I, November 27-29, 2001

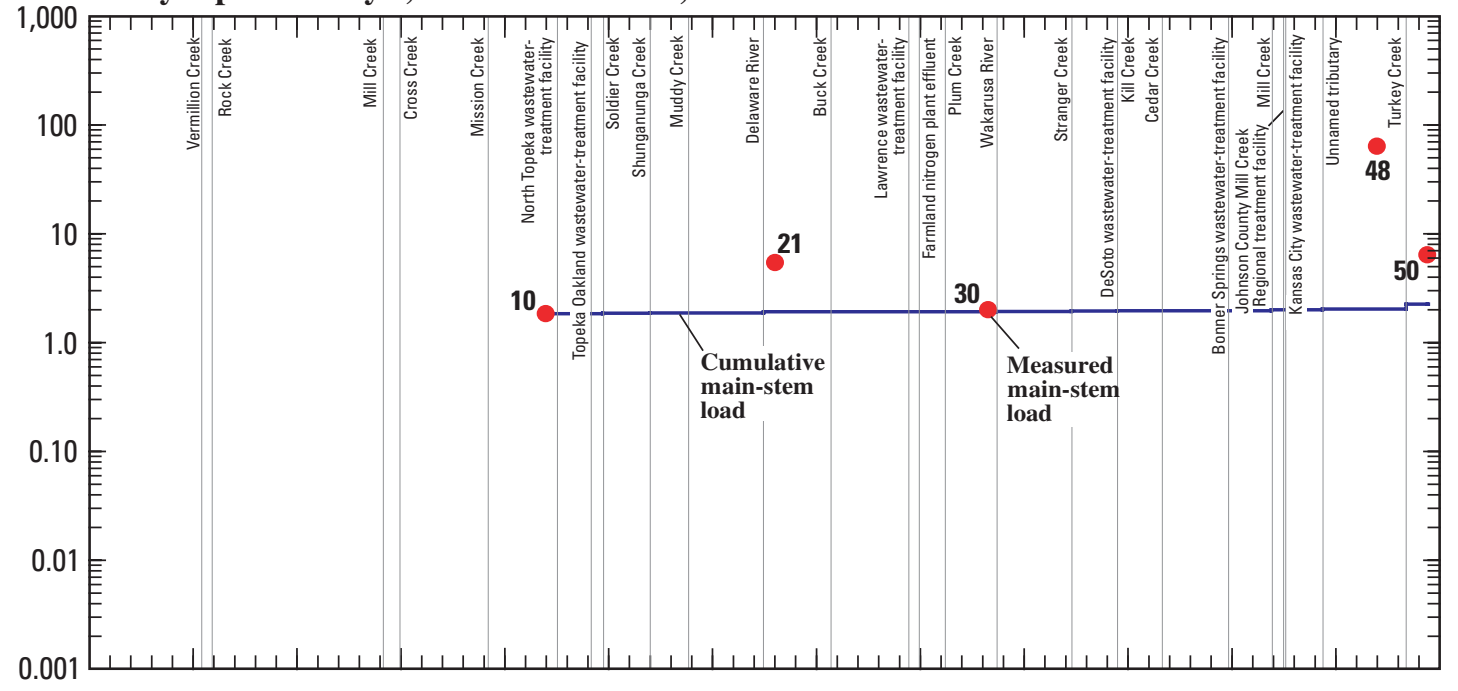

B. Synoptic survey II, February 25-March 1, 2002
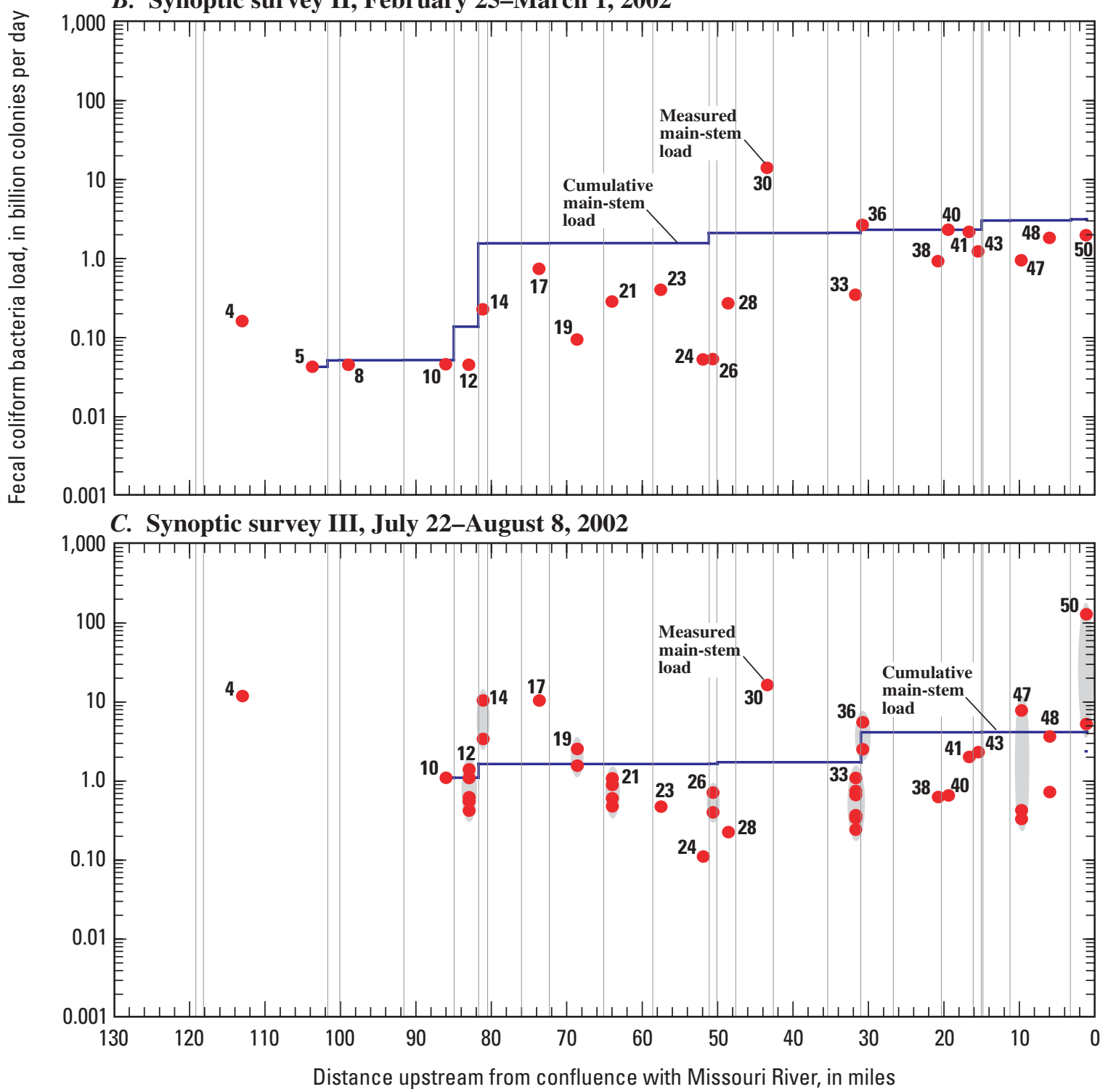

Figure 23. Calculated measured and cumulative loads of fecal coliform bacteria in Kansas River for $(A)$ synoptic survey I, (B) synoptic survey II, and (C) synoptic survey III. Location of sampling sites shown by map number in figure 2. Gray shading indicates multiple samples collected at a site. 


\section{Simulation of Ammonia Assimilative Capacity and Bacteria Transport}

As urban growth continues along the Kansas River, increases in WWTF discharges and discharges from new WWTFs will affect the water quality of the river. Determination of the assimilative capacity for ammonia and bacteria densities in the Kansas River would provide the information needed to better manage the resource and to incorporate future population growth without exceeding water-quality criteria. To help with this effort, a water-quality model was developed to simulate the effects of hypothetical increases in WWTF discharges and new WWTFs along the Kansas River. The results of such hypothetical simulations will aid in planning and decisionmaking in the management of current and future output of WWTFs.

The numerical modeling code known as CE-QUAL-W2, version 3.1 (Cole and Wells, 2003), was configured for application to the Kansas River. The computer model is a two-dimensional, laterally averaged, hydrodynamic and water-quality model. The model was calibrated and tested using data from three synoptic surveys conducted between November 2001 and August 2002.

\section{Data for Model Application}

Many types of data were required for CE-QUAL-W2 to simulate the streamflow and water quality in the Kansas River. Bathymetric cross sections were necessary to define the model grid. The quantity and quality of water flowing into the model grid were measured or estimated. Meteorological data were needed primarily for proper simulation of the heat budget. The paragraphs that follow describe these data.

\section{River Bathymetry and Model Grid}

A numerical grid was constructed to represent the bathymetry of the Kansas River. The grid extended $83 \mathrm{mi}$ along the main-stem Kansas River from the Sardou Bridge in Topeka, Kansas (site 12, model segment 2, fig. 24), to just upstream from the confluence of the Kansas River with the Missouri River (segment 134, fig. 24). The model domain included:

1. Primary inflow from the Kansas River upstream from Topeka.

2. Inflow from 12 major tributaries-Soldier Creek (segment 5), Shunganunga Creek (segment 13), Muddy Creek (segment 18), Delaware River (segment 30), Buck Creek (segment 40), Mud Creek (segment 58), Wakarusa River (segment 66), Stranger Creek (segment 78), Kill Creek (segment 85), Cedar Creek (segment 92), Mill Creek (segment 110), and Turkey Creek (segment 130).

3. Eight point sources-Topeka Oakland WWTF (segment 3), Lawrence WWTF (segment 53), Farmland effluent (segment 54), DeSoto WWTF (segment 85),
Bonner Springs WWTF (segment 102), Johnson County Mill Creek Regional WWTF (segment 111), and Kansas City no. 20 WWTF (segment 112).

4. A main-stem low-water dam near Lawrence (segment 51).

The U.S. Army Corps of Engineers provided an electronic file containing data for 129 surveyed cross sections of the Kansas River between Kansas City and Topeka (Kenneth A. Stark, U.S. Army Corps of Engineers, Kansas City District, written commun., 2003). Cross sections for each segment in the computational grid were calculated by interpolating between the nearest two surveyed cross sections. The resulting grid was made up of 134 segments, each 0.6-mi long, oriented along the longitudinal axis of the river. Variable water levels in the stream were represented by $1-\mathrm{ft}$ thick computational layers that were stacked vertically and sloped at $0.0018 \mathrm{ft} / \mathrm{mi}$. The layers were divided into cells that represented the width of the stream at each segment (fig. 25). The cells were $0.6 \mathrm{mi}$ long, $1 \mathrm{ft}$ thick, and varied from 16 to $1,400 \mathrm{ft}$ wide.

The model grid of the Kansas River was divided into two parts because of the operation of Bowersock Dam and its effect on the main-stem streamflow. The western part represented the grid from Topeka (site 12) to 2.2 mi upstream from Bowersock Dam (river mile 51), and the eastern part represented the grid from downstream from Bowersock Dam (river mile 51) to Kansas City (site 50, model segment 134). Simulations for each part of the grid were computed independently.

\section{Boundary Conditions}

Boundary conditions generally were described as a time series of data that defined the input of flow, mass, and heat to the model domain and the output from the model. Data from synoptic surveys II and III were used to calibrate the model, and data from synoptic survey I were used for model verification.

Boundary conditions for each of the synoptic surveys were dependent on season. Synoptic surveys I and II represented very cold, low-flow conditions, whereas synoptic survey III represented hot, low-flow conditions. The boundary conditions were not continuous between synoptic surveys and only represented the conditions during the surveyed periods.

\section{Streamflow}

Streamflow input to the model was determined as follows:

Main-stem input-Hourly streamflow data provided by USGS streamflow-gaging station 06889000, Kansas River at Topeka (fig. 2).

Gaged tributary input-Hourly streamflow data for the Delaware River and Stranger Creek were provided by USGS streamflow-gaging stations 06890900 and 06892200 , respectively (fig. 2).

Input from WWTFs-Instantaneous flow measurements made during sample collection or instantaneous values reported by the WWTF were used for the entire model period. 


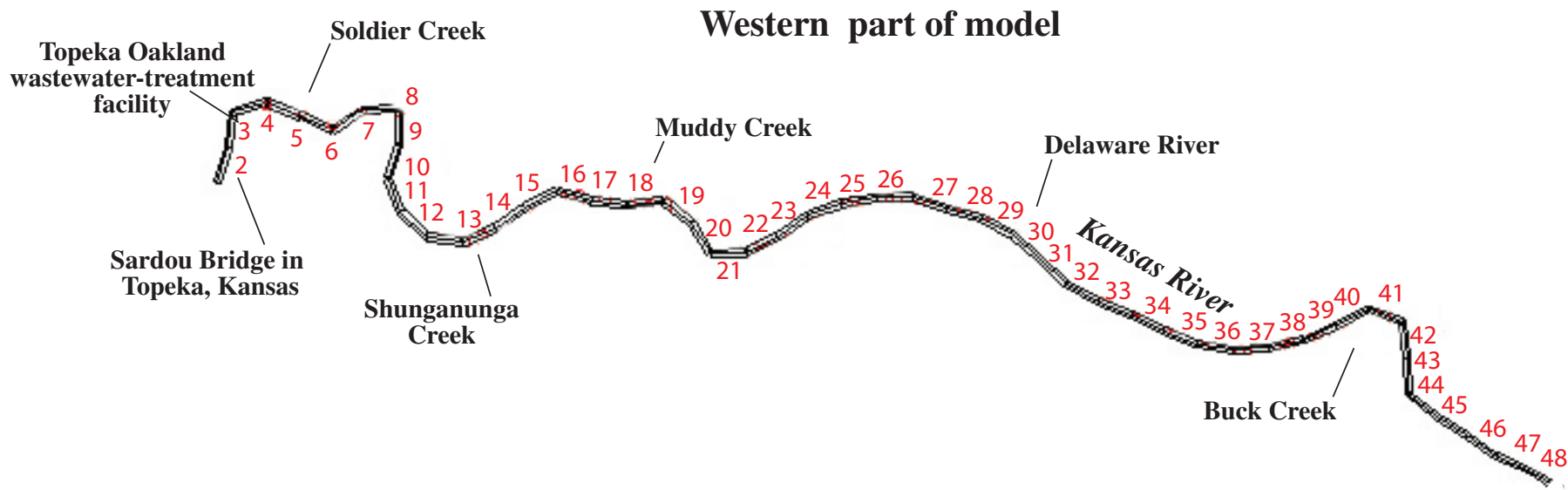

Numbers are model-segment numbers used in water-quality model.

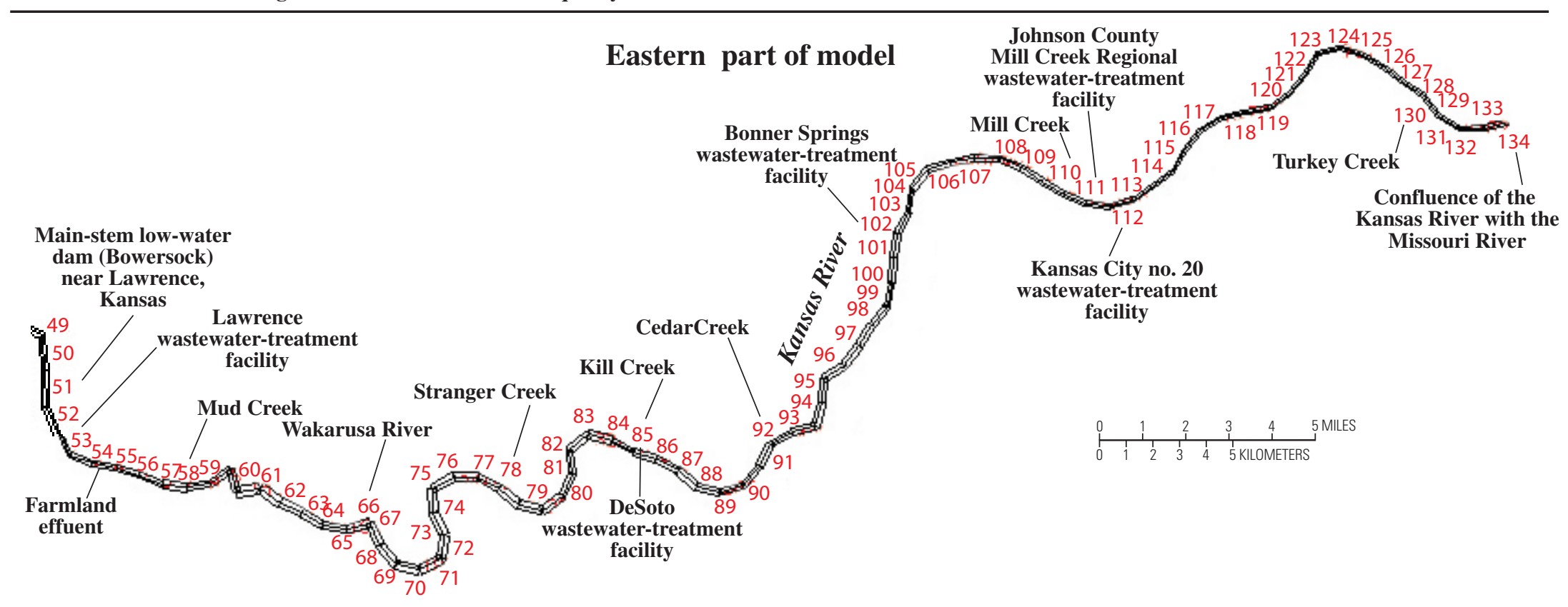

Figure 24. Schematic diagram showing plan view of top layer of computational grid for Kansas River water-quality model. 


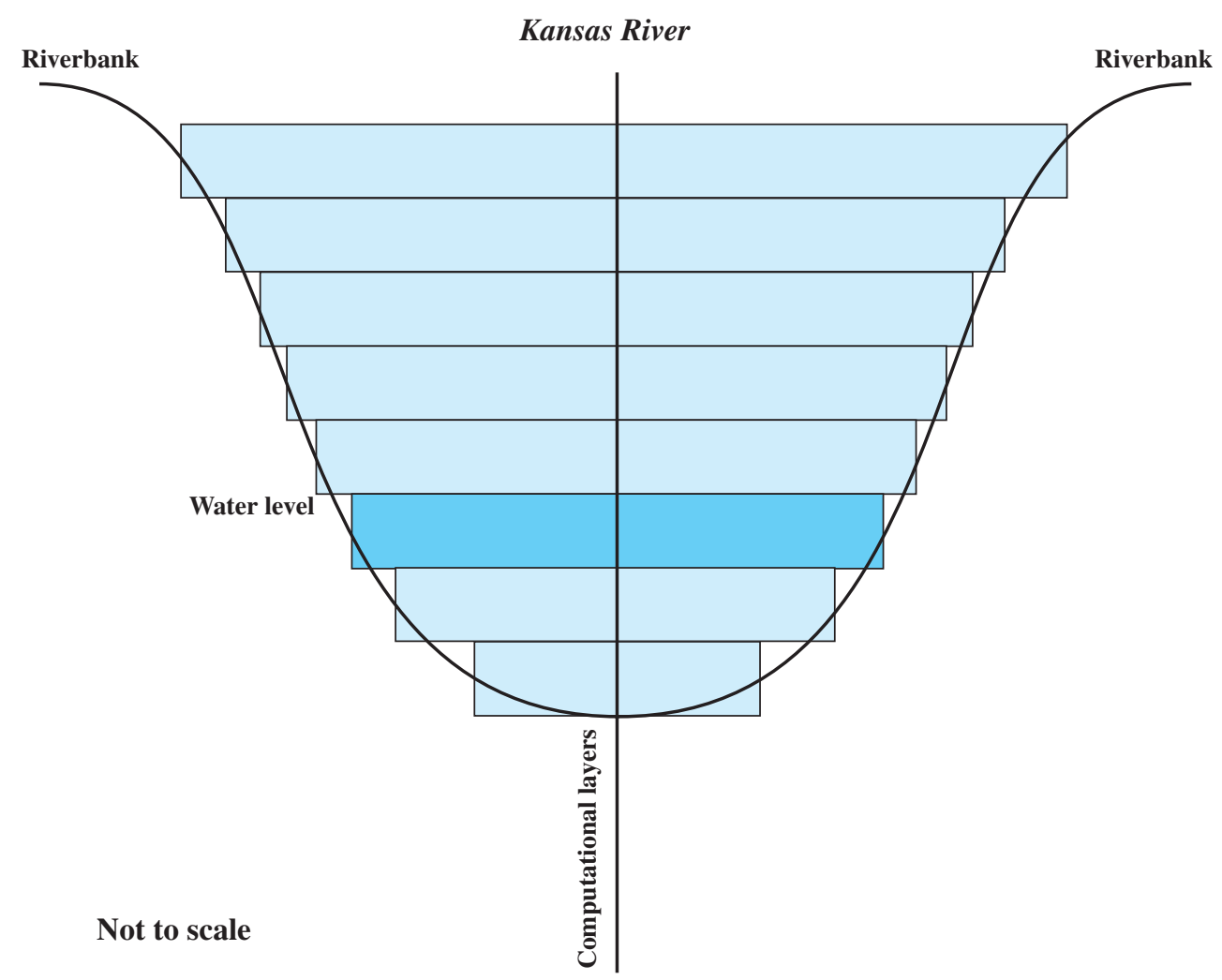

Figure 25. Schematic diagram showing computational layers at model segment 14 for Kansas River water-quality model.

Flow from ungaged tributaries and ground water-Small tributaries and ground-water and surface-water interaction in the Kansas River Basin were not measured during any of the three synoptic surveys. The unmeasured flow of these two components was estimated from the difference between measured and accumulated flows along the main stem (fig. 10). When these differences exceeded 10 percent, these values were distributed along the entire reach of the model grid.

The streamflow resulting from operation of Bowersock Dam was estimated on the basis of the DeSoto hourly streamflow data. Daily operation of the dam caused large daily fluctuations in the streamflow downstream from the dam. The fluctuations were evident in the continuous streamflow data from the streamflow-gaging station at DeSoto (site 33; USGS streamflow-gaging station 06892350). Hourly streamflow data from the gaging station at DeSoto were adjusted for time of travel and used as the streamflow at the dam.

\section{Water Temperature}

Water temperature was measured for water flowing into the model domain during the three synoptic surveys. Water temperature in the main-stem Kansas River was measured hourly at Topeka (site 12). Water temperatures for each of the tributaries and WWTF effluent were estimated on the basis of the water temperature measured during sample collection. In some cases, water temperature of WWTF effluent was estimated from daily measurements obtained from KDHE. The water temperature of the distributed tributary flow was assumed to be $18^{\circ} \mathrm{C}$, the annual average temperature of the Kansas River at DeSoto from October 2000 to September 2001 (Putnam and others, 2002).

\section{Water Chemistry}

The analytical results for selected water-quality constituents included dissolved oxygen, carbonaceous biochemical oxygen demand, nitrite plus nitrate, orthophosphorus, ammonia as nitrogen, fecal coliform bacteria, algae, and suspended sediment and were used for input to the model domain for each synoptic survey. A constant value for each selected constituent for each modeling period was assumed on the basis of the measured value from samples collected during each synoptic survey at each input. When available, additional values for water-quality constituents from KDHE were used. The water chemistry for the unsampled tributaries was assumed to be the average of the values used for the sampled tributaries. Simulated water-quality constituents within and at the outflow of the model domain were compared with analytical results from water-quality samples. Average water-quality values were used to initialize the model. 


\section{Meteorological Conditions}

The meteorological input for the model was measured hourly at Topeka Philip Billard Municipal Airport. These data included air temperature, dew-point temperature, wind speed, wind direction, and percentage of cloud cover estimated from qualitative descriptions. The original hourly cloud cover data were recorded as clear (CLR), few scattered clouds (FEW), scattered clouds (SCT), broken clouds (BKN), completely overcast with clouds (OVC), and no vertical visibility (VV). For the Kansas River model, cloud cover was translated into numerical values so that $\mathrm{CLR}=0, \mathrm{FEW}=1.9, \mathrm{SCT}=4.4, \mathrm{BKN}=7.5$, $\mathrm{OVC}=10$, and $\mathrm{VV}=10$. Any missing values were estimated by linear interpolation between two recorded values.

\section{Model Calibration and Testing}

The Kansas River water-quality model was calibrated by adjusting the computational grid, model parameters, and in some cases, estimated boundary data. The model was calibrated for low streamflow conditions during winter and summer using data from synoptic surveys II and III, respectively. The calibration sequence was (1) water balance, (2) water temperature, and (3) water chemistry.

Two statistics were used to compare measured and simulated values. The absolute mean error (AME) is the average difference between measured and simulated values according to the following equation:

$$
A M E=\frac{\sum \mid \text { Simulated }- \text { Measured } \mid}{\text { Number of observations }} .
$$

For example, an AME of $100 \mathrm{ft}^{3} / \mathrm{s}$ means that the simulated streamflows were within $\pm 100 \mathrm{ft}^{3} / \mathrm{s}$. The root mean square error (RMSE) indicates the spread of how far simulated values deviated from the measured data, according to the following equation:

$$
R M S E=\sqrt{\frac{\sum(\text { Simulated }- \text { Measured })^{2}}{\text { Number of observations }}} .
$$

\section{Simulated Hydrodynamics}

The initial model grid was adjusted to ensure reasonable flow conditions and numerical stability. The bottom of some segments were lowered by as much as $2 \mathrm{ft}$ (or two layers) to smooth the transition between some of the segments.

Simulated streamflow was compared to continuous streamflow during synoptic surveys II and III at USGS streamflow-gaging stations at Lecompton (site 21) and DeSoto (site 33). Key features of the comparison were the timing of notable runoff periods and the magnitude of streamflow. For synoptic survey III, a small runoff period provided a marker for assessing the timing of the streamflow from Topeka to DeSoto. The friction coefficient (Mannings $\mathrm{n}$ ) for the segments along this reach of the river was adjusted within acceptable values $(0.015-0.040)$ so that the timing of the simulated peak for that runoff period matched the timing of the measured peak. Once the friction was adjusted properly, the magnitude of flow was adjusted slightly to account for ground-water flux. For example, the simulated continuous streamflows for synoptic surveys II and III were about 180 and $280 \mathrm{ft}^{3} / \mathrm{s}$, respectively, greater than the measured streamflows at Lecompton. The difference between the simulated and the measured values was used to estimate the total amount of streamflow lost to ground water for the segment from Topeka to Lawrence. The respective loss was uniformly distributed to each of the 0.6-mi segments for this reach in the model.

AMEs of the simulated versus measured streamflow at Lecompton during synoptic surveys II and III were \pm 42 and $46 \mathrm{ft}^{3} / \mathrm{s}$ (or less than 3 percent) of the measured streamflow, respectively (fig. 26). The measured streamflow for Lecompton during synoptic survey II was affected by ice for the period February 26-27, 2002. The model did not simulate the effects of ice, and therefore, some of the largest differences between measured and simulated streamflow occurred during this period. The simulated streamflow at Lecompton for synoptic survey III fit the measured flow better than for synoptic survey II. The timing and magnitude of the simulated streamflow during the runoff period for synoptic survey III matched well with the measured streamflow, indicating that the hydrodynamics of the model were well calibrated.

The differences between measured and simulated streamflow at DeSoto were greater than at Lecompton. The AMEs for streamflow at DeSoto during synoptic surveys II and III were 46 and $60 \mathrm{ft}^{3} / \mathrm{s}$ (or less than 5 percent) (fig. 26), respectively. The primary reason for these differences is the unaccounted for operation of Bowersock Dam.

\section{Simulated Water Temperature}

Water temperature was simulated using inflow water temperature, percentage of cloud cover (available solar radiation), air and dew-point temperature, wind speed, and heat exchange at the sediment-water interface. Simulated water temperature could have been adjusted to consider the effects of reduced light penetration due to suspended sediment. The effects of shading and suspended sediment on light penetration and thus water temperature during low streamflow were assumed to be negligible and were not included in the model.

Within the model domain, water temperature was measured hourly at DeSoto (site 33) during the three synoptic surveys. During synoptic survey III, water temperature was measured hourly at Lecompton (site 21) and Kansas City (site 50). The hourly data from these three main-stem sites provided a basis for comparison of simulated versus measured water temperatures.

Hourly water temperature measured at Lecompton (site 21) was compared to simulated water temperature during synoptic survey III (fig. 27A). The AME was $2.4{ }^{\circ} \mathrm{C}$, indicating that the model did well simulating hourly water temperature at this location. The magnitude and the timing of the diurnal 
A. Lecompton, synoptic survey II, February 25-March 1, 2002

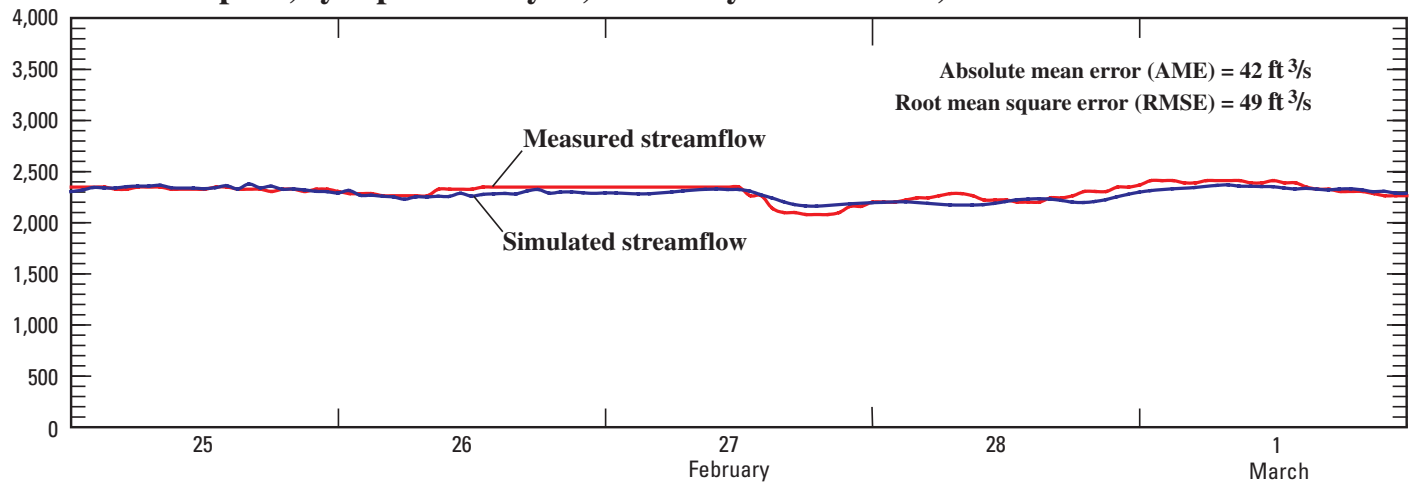

B. DeSoto, synoptic survey II, February 25-March 1, 2002

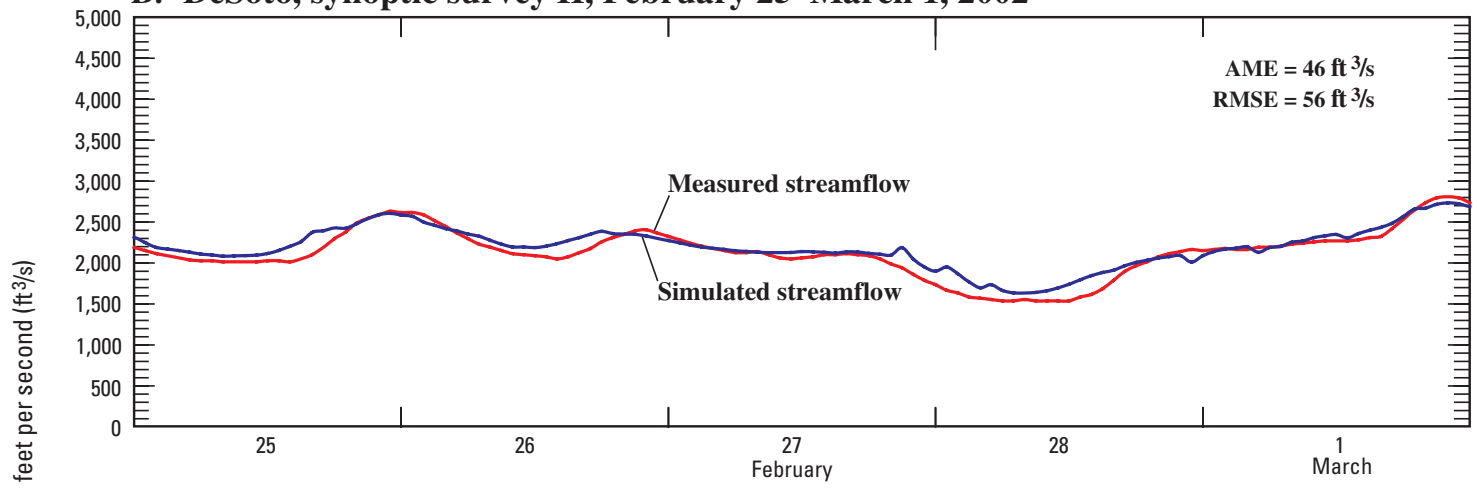

C. Lecompton, synoptic survey III, July 22-August 8, 2002

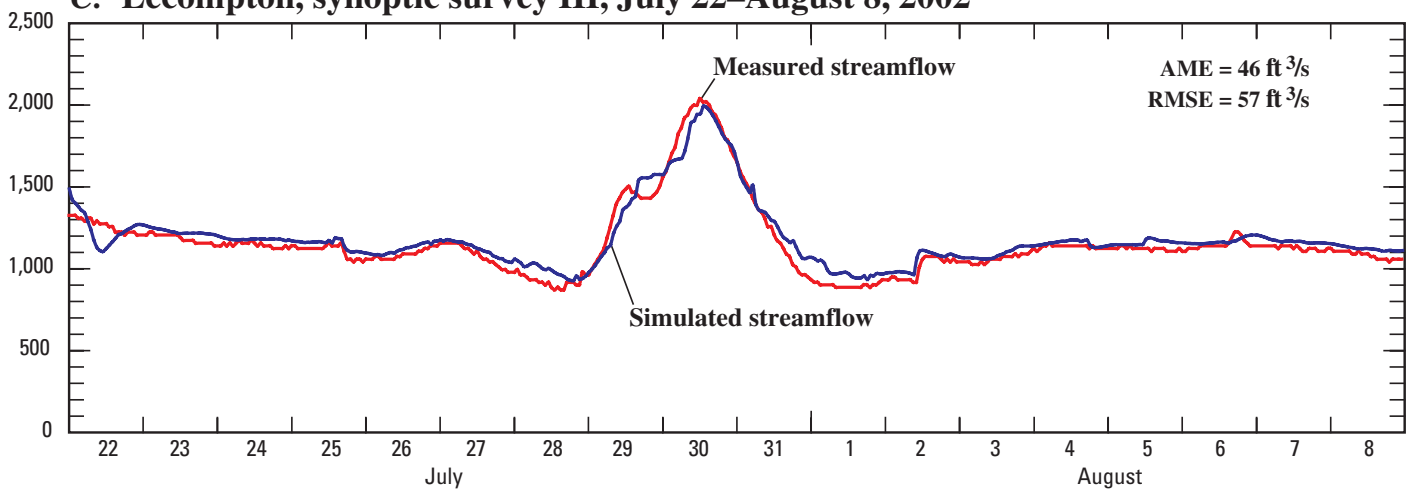

D. DeSoto, synoptic survey III, July 22-August 8, 2002

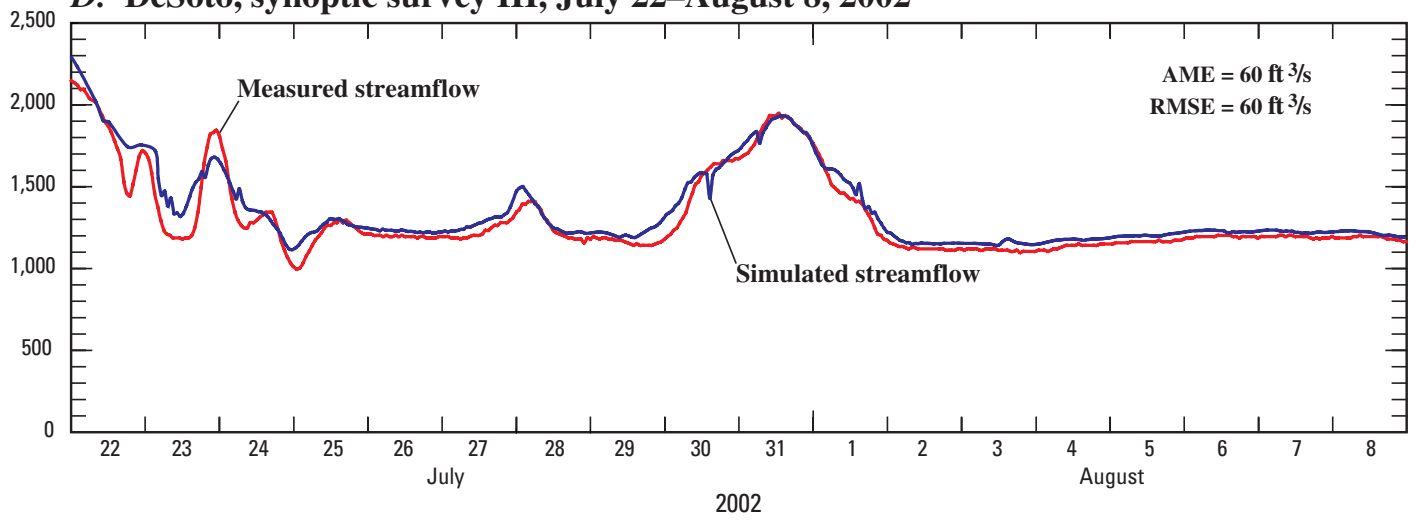

Figure 26. Measured and simulated hourly streamflows in Kansas River at Lecompton (site 21) and DeSoto (site 33 ) for $(A-B)$ synoptic survey II and $(C-D)$ synoptic survey III. Location of sampling sites shown in figure 2. 
A. Lecompton, synoptic survey III, July 22-August 8, 2002

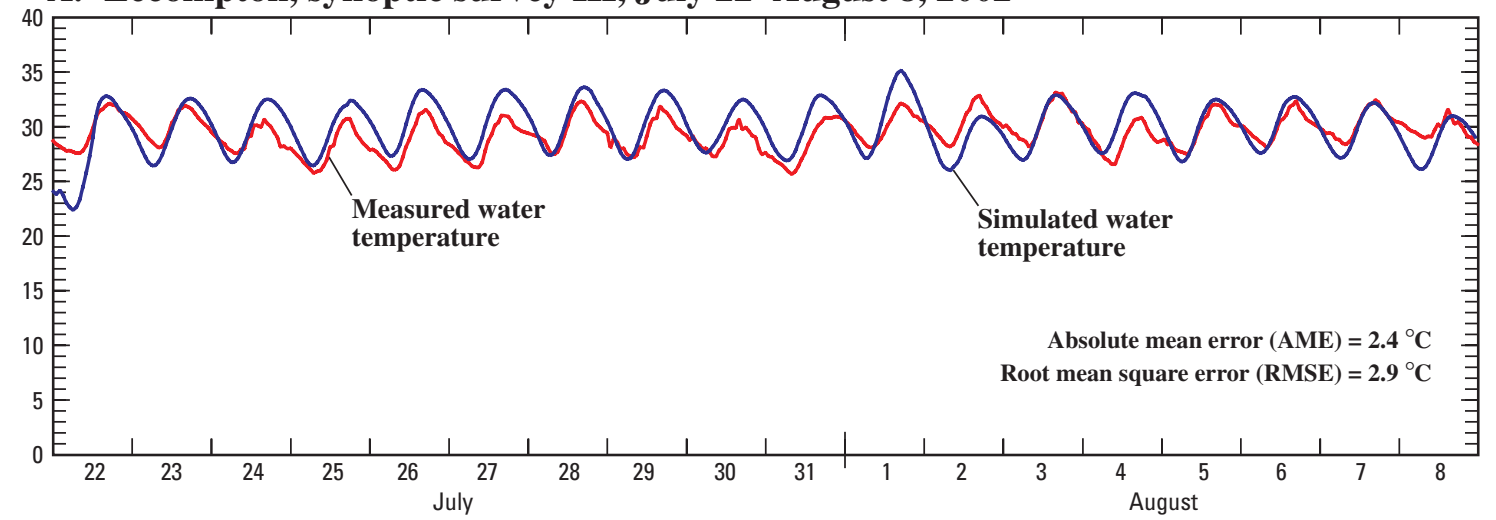

B. DeSoto, synoptic survey II, February 25-March 1, 2002

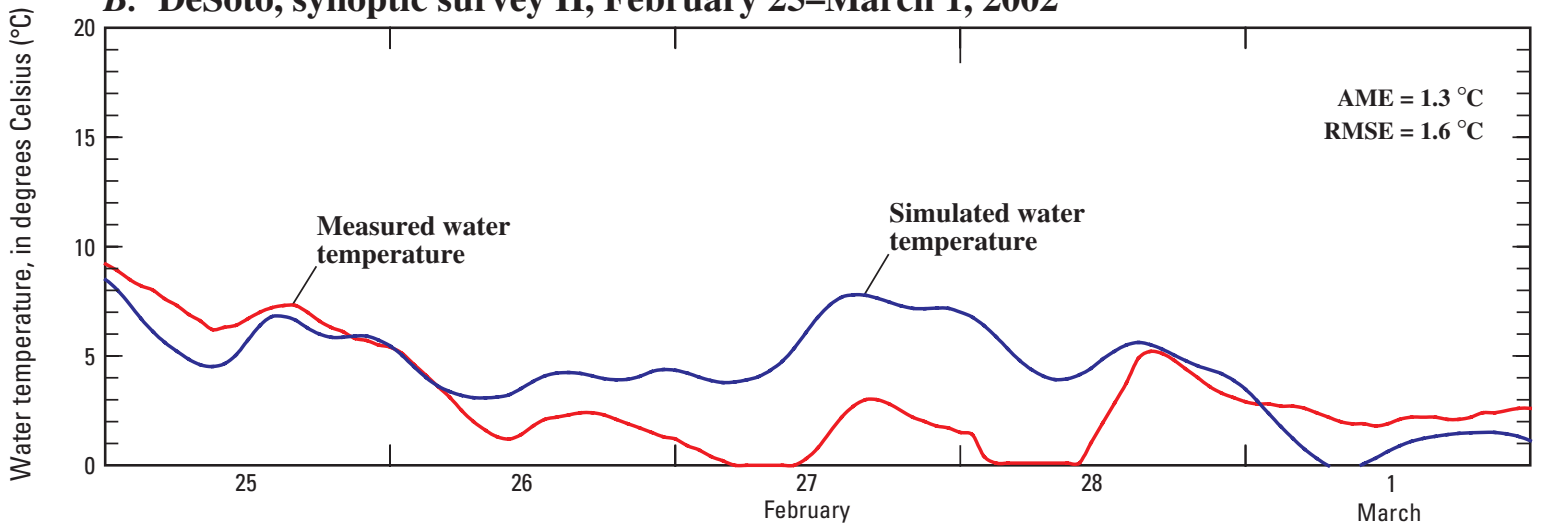

C. DeSoto, synoptic survey III, July 22-August 8, 2002

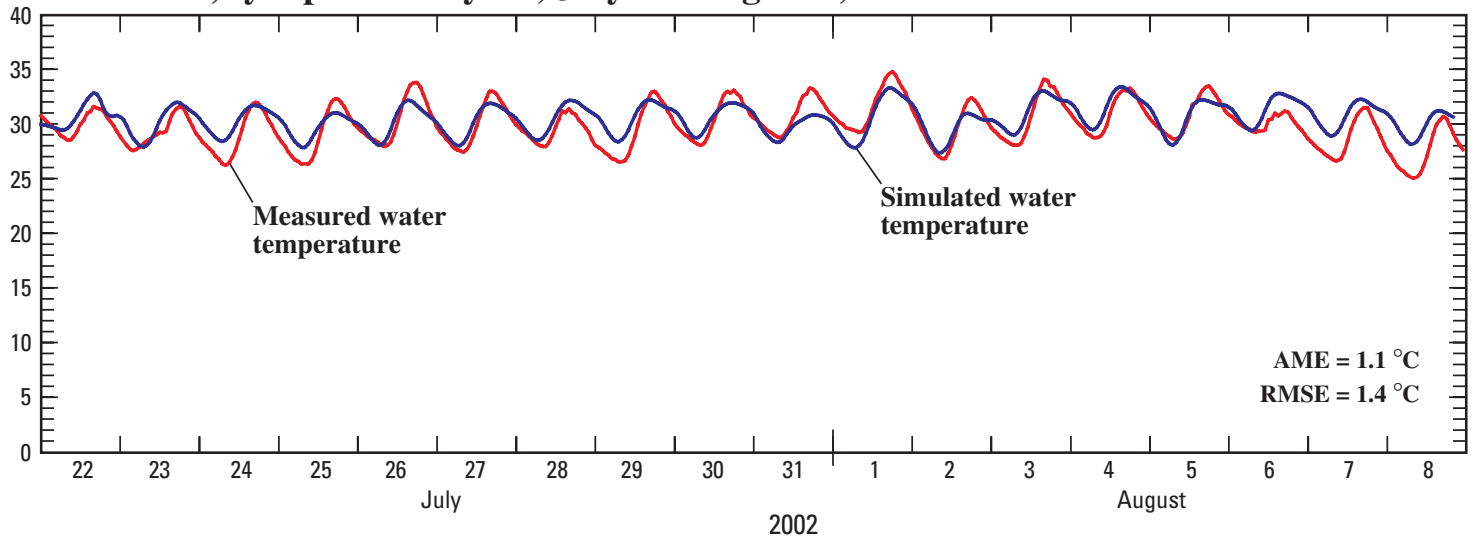

Figure 27. Measured and simulated hourly water temperatures in Kansas River at Lecompton (site 21) and DeSoto (site 33) for synoptic survey II and synoptic survey III. Location of sampling sites shown in figure 2.

fluctuations were similar to the measured fluctuations with a few exceptions.

Hourly measured water temperature was compared to hourly simulated water temperature for synoptic surveys II and III at DeSoto (site 33). The AMEs were $1.3{ }^{\circ} \mathrm{C}$ for synoptic survey II (fig. $27 B$ ) and $1.1^{\circ} \mathrm{C}$ for synoptic survey III (fig. 27C). Generally, the timing and the magnitude of daily temperature fluctuations were well simulated during synoptic survey II. One exception was when simulated water temperature overestimated the measured water temperature on February 27-28,
2002. This was most likely due to ice forming on the surface of the river and insulating the water from the available solar radiation, in this case lowering the measured temperature of the water. The simulated water temperature was based on open water and, therefore, higher water temperatures.

\section{Simulated Water Quality}

The model was calibrated for water quality by adjusting model parameters (table 11) to achieve acceptable agreement 
Table 11. Model parameters and calculated values specified as input for water-quality model of Kansas River in northeast Kansas.

[--, not applicable]

\begin{tabular}{|c|c|c|}
\hline Model parameter & Unit of measurement & $\begin{array}{l}\text { Calibrated value in } \\
\text { lower Kansas River } \\
\text { water-quality model }\end{array}$ \\
\hline Light extinction coeficient for water & $1 /$ meter & $\begin{array}{l}0.45 \text { (winter) } \\
.25 \text { (summer) }\end{array}$ \\
\hline Fraction of incident solar radiation absorbed at the water surface & dimensionless & .45 \\
\hline Group 1 algal light extinction & $1 /$ meter & .1 \\
\hline First-order fecal coliform decay rate & 1/day & 1.4 \\
\hline Coliform decay rate temperature coefficient & dimensionless & 1.04 \\
\hline Suspended solids settling rate & meter per day & 1 \\
\hline Maximum algal growth rate & 1/day & 2 \\
\hline Maximum algal respiration rate & 1/day & .02 \\
\hline Maximum algal excretion rate & 1/day & .01 \\
\hline Maximum algal mortality rate & 1/day & .1 \\
\hline Algal settling rate & meter per day & .15 \\
\hline Algal half-saturation constant for phosphorus & milligrams per liter & .005 \\
\hline Algal half-saturation constant for nitrogen & milligrams per liter & .014 \\
\hline Algal half-saturation constant for silica & milligrams per liter & 0 \\
\hline Light saturation intensity at maximum photosynthetic rate & watts per square meter & 75 \\
\hline Lower temperature for algal growth & degrees Celsius & 1 \\
\hline Lower temperature for maximum algal growth & degrees Celsius & 15 \\
\hline Upper temperature for maximum algal growth & degrees Celsius & 35 \\
\hline Upper temperature for algal growth & degrees Celsius & 40 \\
\hline Fraction of maximum algal growth at lower temperature & dimensionless & .1 \\
\hline Fraction of algal growth at lower temperature & dimensionless & .99 \\
\hline Fraction of maximum algal growth at upper temperature & dimensionless & .99 \\
\hline Fraction of algal growth at upper temperature & dimensionless & .1 \\
\hline Stoichiometric equivalent between algal biomass and phosphorus & dimensionless & .005 \\
\hline Stoichiometric equivalent between algal biomass and nitrogen & dimensionless & .08 \\
\hline Stoichiometric equivalent between algal biomass and carbon & dimensionless & .45 \\
\hline Stoichiometric equivalent between algal biomass and silica & dimensionless & 0 \\
\hline Ratio between algal biomass and chlorophyll- $a$ & dimensionless & 145 \\
\hline $\begin{array}{l}\text { Fraction of algal biomass that is converted to particulate organic matter when } \\
\text { algae die }\end{array}$ & dimensionless & 0.8 \\
\hline Equation number for algal ammonium preference ( 1 or 2 ) & -- & 1 \\
\hline Algal half-saturation constant for ammonium preference & dimensionless & .001 \\
\hline Labile dissolved organic matter decay rate & $1 /$ day & .1 \\
\hline Refractory dissolved organic matter decay rate & 1/day & .001 \\
\hline Labile to refractory dissolved organic matter decay rate & 1/day & .01 \\
\hline Labile particulate organic matter decay rate & 1/day & .08 \\
\hline
\end{tabular}


Table 11. Model parameters and calculated values specified as input for water-quality model of Kansas River in northeast Kansas.-Continued

[--, not applicable]

\begin{tabular}{|c|c|c|}
\hline Model parameter & Unit of measurement & $\begin{array}{c}\text { Calibrated value in } \\
\text { lower Kansas } \\
\text { Riverwater-quality } \\
\text { model }\end{array}$ \\
\hline Refractory particulate organic matter decay rate & 1/day & 0.001 \\
\hline Labile to refractory particulate organic matter decay rate & 1/day & .01 \\
\hline Particulate organic matter settling rate & 1/day & .1 \\
\hline Stoichiometric equivalent between organic matter and phosphorus & dimensionless & .005 \\
\hline Stoichiometric equivalent between organic matter and nitrogen & dimensionless & .08 \\
\hline Stoichiometric equivalent between organic matter and carbon & dimensionless & .45 \\
\hline Stoichiometric equivalent between organic matter and silica & dimensionless & .18 \\
\hline Lower temperature for organic matter decay & degrees Celsius & 4 \\
\hline Upper temperature for organic matter decay & degrees Celsius & 30 \\
\hline Fraction of organic matter decay rate at lower temperature & dimensionless & .1 \\
\hline Fraction of organic matter decay rate at upper temperature & dimensionless & .99 \\
\hline 5 -day decay rate at $20^{\circ} \mathrm{C}$ & 1/day & .2 \\
\hline Temperature coefficient & dimensionless & 1.047 \\
\hline $\begin{array}{l}\text { Ratio of 5-day carbonaceous biochemical oxygen demand to ultimate } \\
\text { carbonaceous biochemical oxygen demand }\end{array}$ & dimensionless & 1.85 \\
\hline Phosphorus stoichiometry for carbonaceous biochemical oxygen demand decay & dimensionless & .004 \\
\hline Nitrogen stoichiometry for carbonaceous biochemical oxygen demand decay & dimensionless & .004 \\
\hline Carbon stoichiometry for carbonaceous biochemical oxygen demand decay & dimensionless & .004 \\
\hline Silica stoichiometry for carbonaceous biochemical oxygen demand decay & dimensionless & -- \\
\hline Sediment release rate of phosphorus, fraction of sediment oxygen demand & dimensionless & .01 \\
\hline Phosphorus partitioning coefficient for suspended solids & dimensionless & 0 \\
\hline Sediment release rate of ammonium, fraction of sediment oxygen demand & dimensionless & .001 \\
\hline Ammonium decay rate & 1/day & 1 \\
\hline Lower temperature for ammonia decay & degrees Celsius & 1 \\
\hline Lower temperature for maximum ammonia decay & degrees Celsius & 25 \\
\hline Fraction of nitrification rate at lower temperature & dimensionless & .5 \\
\hline Fraction of nitrification rate at upper temperature & dimensionless & .99 \\
\hline Nitrate decay rate & 1/day & .15 \\
\hline Denitrification rate from sediment & meter per day & 1 \\
\hline Lower temperature for nitrate decay & degrees Celsius & 1 \\
\hline Lower temperature for maximum nitrate decay & degrees Celsius & 25 \\
\hline Fraction of denitrification rate at lower temperature & dimensionless & .1 \\
\hline Fraction of denitrification rate at upper temperature & dimensionless & .99 \\
\hline Dissolved silica sediment release rate, fraction of sediment oxygen demand & dimensionless & .1 \\
\hline Particulate biogenic settling rate & meter per second & 0 \\
\hline Particulate biogenic silica decay rate & 1/day & .3 \\
\hline
\end{tabular}


Table 11. Model parameters and calculated values specified as input for water-quality model of Kansas River in northeast Kansas.-Continued

[--, not applicable $]$

\begin{tabular}{|c|c|c|}
\hline Model parameter & Unit of measurement & $\begin{array}{c}\text { Calibrated value in } \\
\text { lower Kansas } \\
\text { Riverwater-quality } \\
\text { model }\end{array}$ \\
\hline Dissolved silica partitioning coefficient & dimensionless & 0.2 \\
\hline Iron sediment release rate, fraction of sediment oxygen demand & dimensionless & .1 \\
\hline Iron settling velocity & meter per day & 2 \\
\hline Sediment carbon dioxide release rate, fraction of sediment oxygen demand & dimensionless & .1 \\
\hline Oxygen stoichiometry for nitrification & dimensionless & 4.57 \\
\hline Oxygen stoichiometry for organic matter decay & dimensionless & 1.4 \\
\hline Oxygen stoichiometry for algal respiration & dimensionless & 1.1 \\
\hline Oxygen stoichiometry for algal primary production & dimensionless & 1.4 \\
\hline Dissolved-oxygen concentration at which anaerobic processes begin & gram per cubic meter & .1 \\
\hline Initial sediment concentration & gram per cubic meter & 1 \\
\hline Sediment decay rate & 1/day & .1 \\
\hline Fraction of the zero-order sediment oxygen demand rate used & dimensionless & 0 \\
\hline Fraction of the first-order sediment rate used & dimensionless & .5 \\
\hline $\begin{array}{l}\text { Lower temperature for zero-order sediment oxygen demand or first-order } \\
\text { sediment decay }\end{array}$ & degrees Celsius & 5 \\
\hline $\begin{array}{l}\text { Upper temperature for zero-order sediment oxygen demand or first-order sediment } \\
\text { decay }\end{array}$ & degrees Celsius & 35 \\
\hline Fraction of sediment oxygen demand or sediment decay rate at lower temperature & dimensionless & .05 \\
\hline Fraction of sediment oxygen demand or sediment decay rate at upper temperature & dimensionless & .99 \\
\hline Sediment oxygen demand & milligram per liter & 1 \\
\hline
\end{tabular}

between measured and simulated dissolved oxygen, nitrite plus nitrate, ammonia as nitrogen, orthophosphorus, fecal coliform bacteria, and algal biomass. These model parameters were set to default values for the first simulation. Parameters then were adjusted on the basis of: (1) conceptual understanding of the system, (2) agreement with measured data, (3) values used for other CE-QUAL-W2 applications (Bales and others, 2001; Galloway and Green, 2002; Berger and others, 2003), and (4) defined limits of each parameter (Cole and Wells, 2003). These adjustments were kept to a minimum to avoid "overtuning" the model and creating a model that is only useful for the data used to calibrate the model.

Accurate dissolved-oxygen simulation was emphasized during the model calibration. Hourly measured dissolved oxygen was available for comparison to hourly simulated dissolved oxygen. Other water-quality constituents were measured during discrete sample collection. During synoptic survey II, one measured value per site, per water-quality constituent, was compared to hourly simulated values. In an effort to define temporal fluctuations for synoptic survey III, multiple samples were collected at Lecompton (site 21), DeSoto (site 33), and Kansas City (site 50).

\section{Dissolved Oxygen}

Comparisons of measured and simulated dissolvedoxygen concentrations indicated fair agreement for the Kansas River at Lecompton and DeSoto. During synoptic survey II, the AME was $0.9 \mathrm{mg} / \mathrm{L}$ for DeSoto (fig. 28A) (no measured dissolved-oxygen data were available for Lecompton). The AME for dissolved-oxygen concentrations at Lecompton and DeSoto for synoptic survey III were 2.8 and $1.9 \mathrm{mg} / \mathrm{L}$, respectively (fig. $28 \mathrm{~B}$ and $28 \mathrm{C}$ ). The magnitudes of the daily maximum and minimum simulated dissolved-oxygen concentrations at Lecompton closely agreed with several of the measured values, but the timing of the daily extremes was slightly out of phase (fig. 28B). The magnitudes of the minimum and maximum simulated dissolved-oxygen concentrations at DeSoto were underestimated in comparison to the measured dissolved-oxygen concentrations (fig. 28C). Also, the simulated dissolved-oxygen concentrations were out of phase with the measured data by about 7 to 8 hours. Overall, the simulated dissolved oxygen for DeSoto for synoptic survey III underestimated the measured dissolved oxygen by as much as $4 \mathrm{mg} / \mathrm{L}$. 
A. DeSoto, synoptic survey II, February 25-March 1, 2002
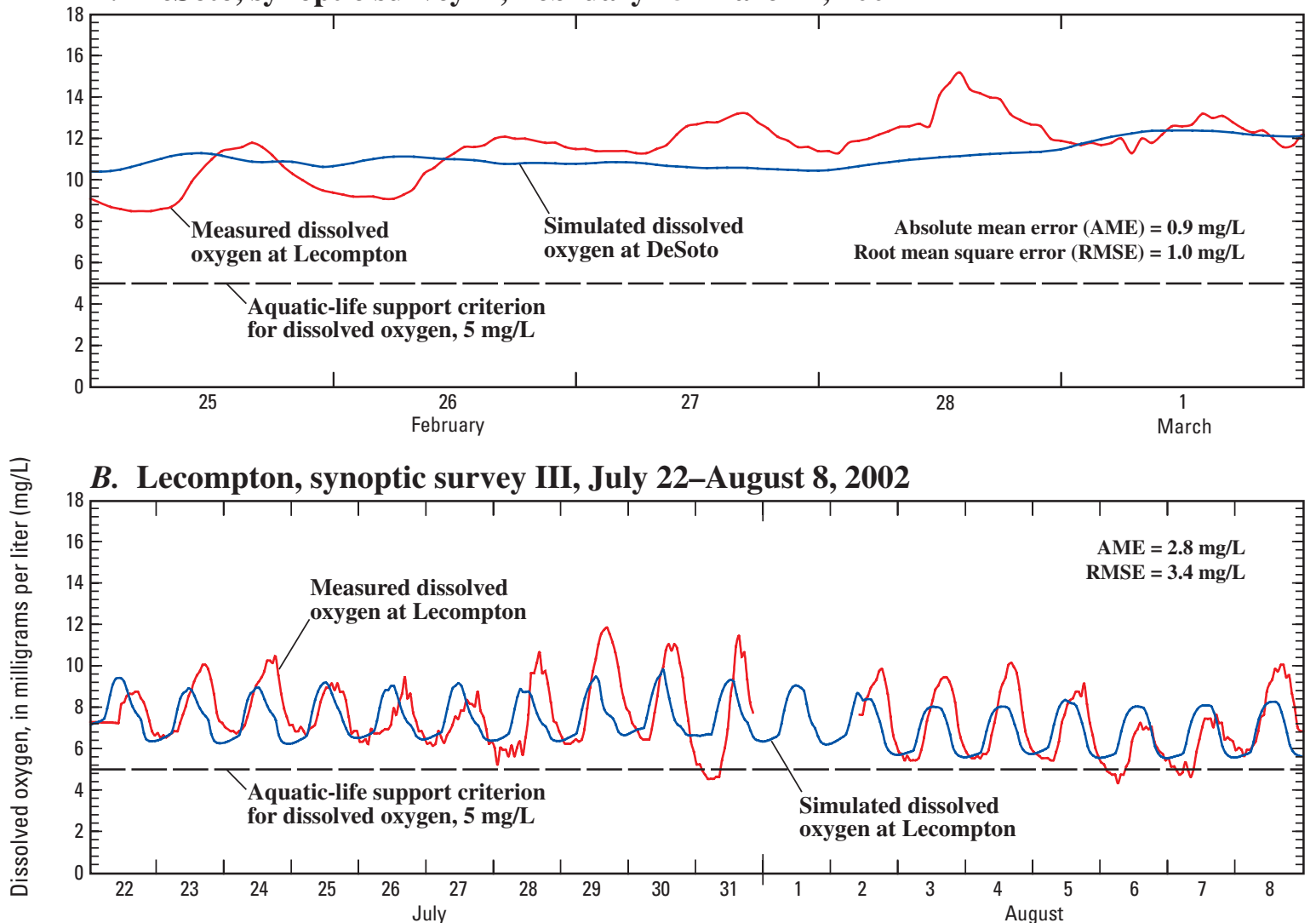

C. DeSoto, synoptic survey III, July 22-August 8, 2002

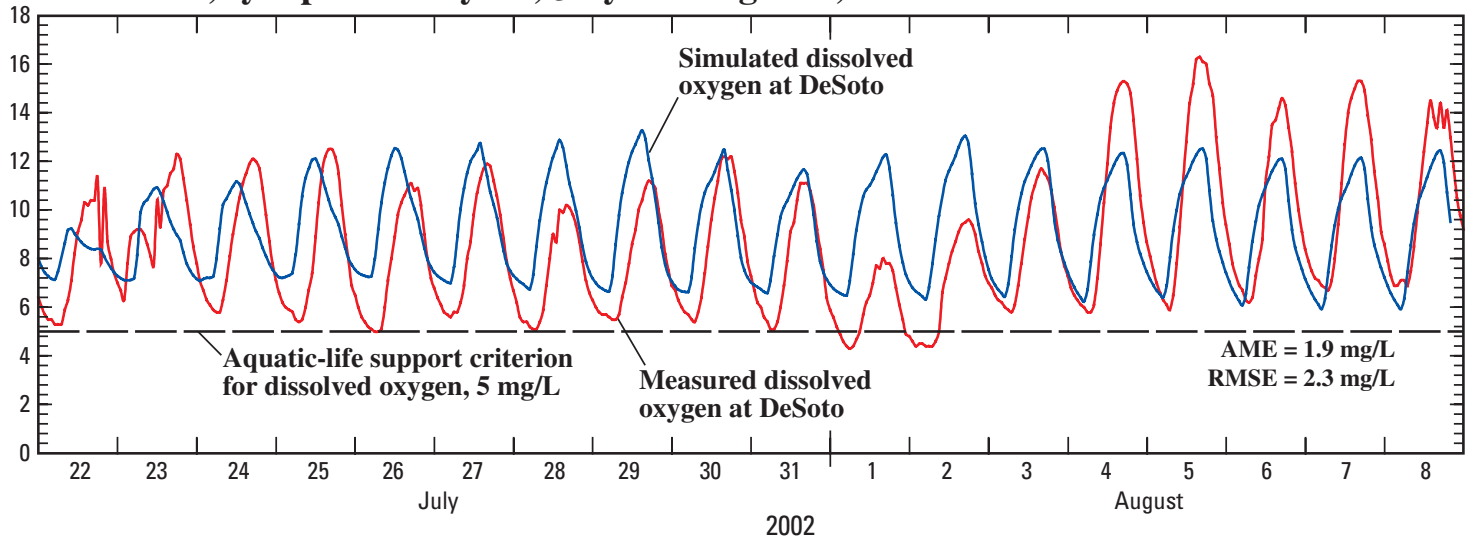

Figure 28. Measured and simulated hourly dissolved-oxygen concentrations in Kansas River at Lecompton (site 21) and DeSoto (site 33) for synoptic survey II and synoptic survey III. Location of sampling sites shown in figure 2. Aquatic-life-support criterion from Kansas Department of Health and Environment (2002).

Adjustments to model parameters were required to improve simulation of measured dissolved-oxygen concentrations. Sources for dissolved-oxygen concentrations include reaeration and photosynthesis. Sinks include algal respiration, nitrification, decay of organic matter, and sediment oxygen demand. The reaeration rate algorithm was adjusted to improve simulation of the actual reaeration of the Kansas River at lower flows. Model parameters controlling algal respiration were adjusted to improve simulation of the diurnal fluctuations of dissolved-oxygen concentrations. The rate of nitrification was adjusted slightly with little effect on dissolved-oxygen concentrations. The decay rates for organic matter were set at their recommended (or default) values (Cole and Wells, 2003). The sediment oxygen demand was set at a constant rate of $1.0 \mathrm{mg} / \mathrm{L}$ for the entire length of the river. 


\section{Ammonia}

Simulated in-stream ammonia concentrations were compared to measured concentrations along the Kansas River (fig. 29). The simulations represented winter (synoptic survey II) and summer (synoptic survey III) conditions with results for midnight and noon, February 27, 2002, and July 29, 2002 , respectively. The time and date of collection for each measured value varied 9 days prior to and after the simulation dates.

The simulated in-stream ammonia concentrations were mostly larger than the measured values for both winter and summer, with a few exceptions. During the winter (synoptic survey II), the simulated values varied from being just slightly less than the measured concentration (site 26) to 5.6 times larger than the measured value (site 50, fig. 29A). Measured and simulated main-stem ammonia concentrations increased substantially just downstream from the Topeka Oakland WWTF (at site 14). The measured ammonia concentration at the WWTF (site 13) on February 26, 2002, was $29.9 \mathrm{mg} / \mathrm{L}$, the largest ammonia concentration measured for all the samples collected for this study. Ammonia concentrations decreased for the succeeding $25 \mathrm{mi}$. At site 23, the measured main-stem ammonia concentration was $0.05 \mathrm{mg} / \mathrm{L}$, and the simulated value was $0.14 \mathrm{mg} / \mathrm{L}$. Discrepancies between measured and simulated ammonia concentrations downstream from Bowersock Dam (downstream from site 24) were indicated from about site 28 to

A. Synoptic survey II, February25-March 1, 2002

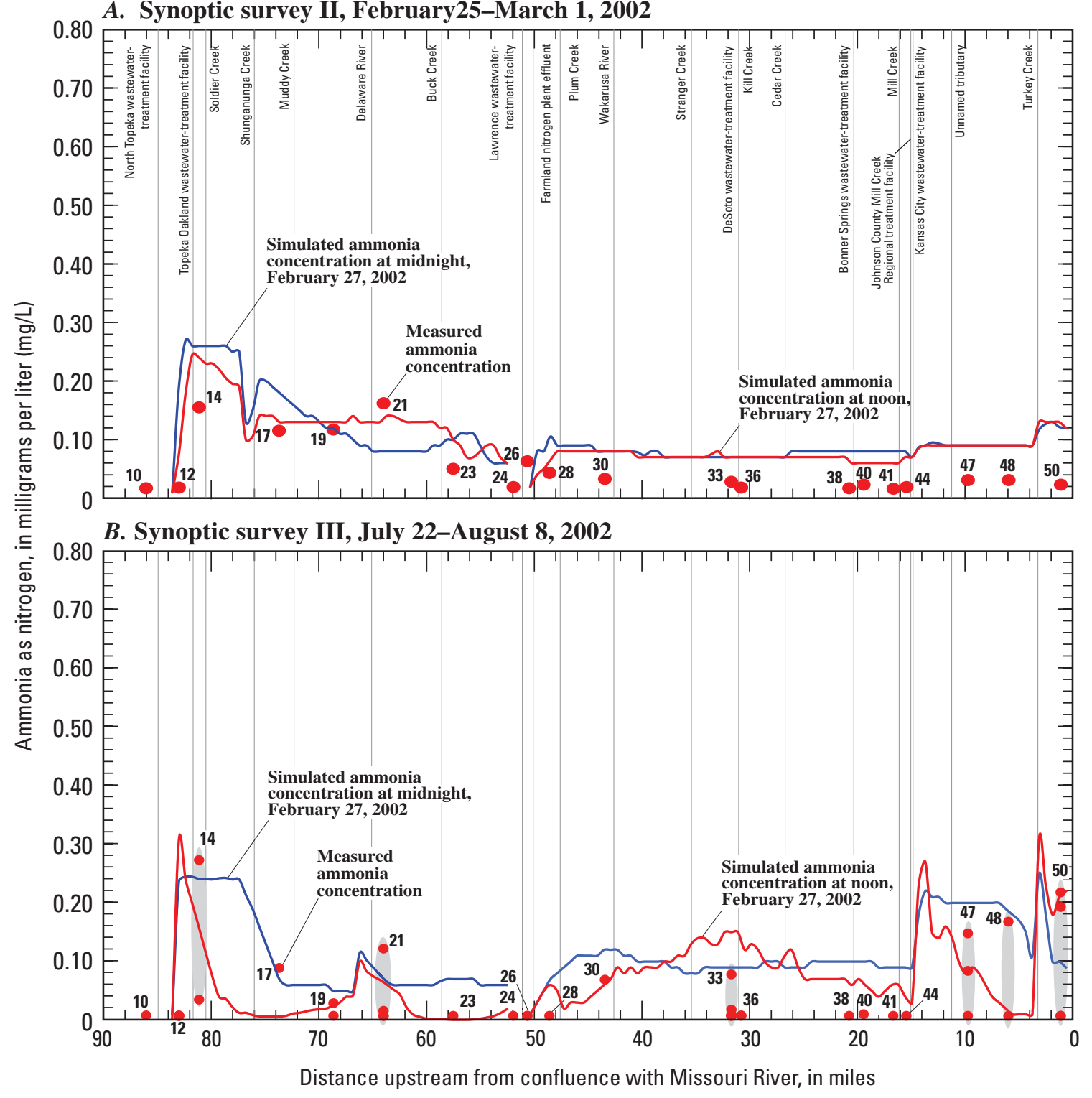

Figure 29. Measured and simulated ammonia concentrations in Kansas River from Topeka to confluence with Missouri River for $(A)$ synoptic survey II and $(B)$ synoptic survey III. Location of sampling sites shown in figure 2. Gray shading indicates multiple samples collected at a single site. 
the confluence with the Missouri River. Measured concentrations along this reach varied from 0.02 to $0.03 \mathrm{mg} / \mathrm{L}$. Simulated concentrations varied from 0.07 to $0.13 \mathrm{mg} / \mathrm{L}$. For this reach, the model simulation indicated that some nitrification occurred, causing simulated ammonia concentration to slightly decrease. Measured values indicated that the actual rate of ammonia assimilation was greater than the modeled rate of assimilation, resulting in measured concentrations being equal to or less than $0.03 \mathrm{mg} / \mathrm{L}$. Winter simulation results at noon and midnight indicate little diurnal fluctuation.

Comparisons between measured and simulated in-stream ammonia concentrations during summer conditions indicated greater agreement between measured and simulated values than during winter conditions (fig. 29B). During the summer, measured ammonia concentrations were mostly near or less than the laboratory reporting level $(0.02 \mathrm{mg} / \mathrm{L})$. Simulated concentrations more accurately represented the variation and magnitude of measured values greater than $0.02 \mathrm{mg} / \mathrm{L}$; for the reach from Topeka (site 12) to Bowersock Dam (river mile 51), measured and simulated ammonia concentrations varied from less than 0.02 to $0.34 \mathrm{mg} / \mathrm{L}$. The most substantial increase occurred near the Topeka Oakland WWTF (site 14) where samples from the WWTF (site 13) indicated ammonia concentrations at $21 \mathrm{mg} / \mathrm{L}$. Simulated in-stream noon concentrations decreased to $0.01 \mathrm{mg} / \mathrm{L}$ within about $8 \mathrm{mi}$ downstream from the Topeka Oakland WWTF. Simulated concentrations then varied from 0.02 to $0.20 \mathrm{mg} / \mathrm{L}$ for the downstream $24 \mathrm{mi}$. The measured concentrations for the reach between Bowersock Dam and Kansas City varied spatially and temporally. The largest concentrations for this reach were from samples collected along the last $10 \mathrm{mi}$, downstream from the Johnson County Mill Creek Regional WWTF (site 44), Kansas City no. 14 (site 46), no. 20 (site 45), and Nelson WWTFs (site 49). At sampling sites where multiple samples were collected, variations among ammonia concentration indicated how dynamic the system can be. Measured ammonia concentrations that were greater than the laboratory reporting level plotted between the simulated daily minimum (noon) and maximum (midnight) concentrations, indicating that the model's simulated diurnal fluctuation in ammonia concentrations properly bracketed the measured concentration.

The discrepancies between the measured and simulated ammonia concentrations come from several possibilities. First, as indicated by the temporal sampling during synoptic survey III, ammonia concentrations can vary by as much as 155 percent over a few days. Some of the measured values were collected 9 days before or after the simulated values. Another possible explanation for the large discrepancies between the measured ammonia concentrations is that the inputs to the river are not steady state and varied substantially during the synoptic period. It also could be possible that the dynamic nature of the chemical and biological components of the river are such that the data that were collected were not sufficient to completely quantify processes affecting actual in-stream nitrification.

\section{Fecal Coliform Bacteria}

Hourly simulated fecal coliform bacteria densities for synoptic survey II (February 25 through March 1) were plotted for the period and compared to one measured value at Lecompton and DeSoto (fig. 30A and $B$ ). Simulated fecal coliform bacteria densities at Lecompton ranged from 22 to $34 \mathrm{col} / 100 \mathrm{~mL}$, whereas the measured value on February 27, 2002, was $7 \mathrm{col} / 100 \mathrm{~mL}$. The measured value at DeSoto on February 25, 2002 , was $10 \mathrm{col} / 100 \mathrm{~mL}$, and the hourly simulated values ranged from 9 to $22 \mathrm{col} / 100 \mathrm{~mL}$ (fig. $30 B$ ).

Hourly simulated fecal coliform bacteria densities at Lecompton for synoptic survey III (July 22 through August 8, 2002) varied between 6 and $20 \mathrm{col} / 100 \mathrm{~mL}$. The measured densities in four discrete samples varied from less than 10 to $13 \mathrm{col} / 100 \mathrm{~mL}$ (fig. 30C). Simulated values slightly overestimated the four discrete samples. At DeSoto, hourly simulated values for fecal coliform bacteria varied from 2 to $18 \mathrm{col} /$ $100 \mathrm{~mL}$. The seven samples collected had densities that ranged from 9 to $14 \mathrm{col} / 100 \mathrm{~mL}$ (fig. 30D). Variation of the hourly simulated fecal coliform bacteria densities is due primarily to variations in hydrodynamics and bacteria input.

\section{Sensitivity Analysis}

Sensitivity analysis was performed on the water-quality model by determining the effects of changes in calibrated model parameters and boundary conditions on simulated results. A complete sensitivity analysis of all the model parameters (table 11) was not performed. However, many of these parameters were adjusted during the calibration process for hydrodynamics, water temperature, dissolved oxygen, and ammonia. Results of these simulations and previous modeling studies (Bales and others, 2001; Galloway and Green, 2002; Berger and others, 2003) using CE-QUAL-W2 formed the basis for the sensitivity analysis.

Simulated streamflow was very sensitive to changes in channel slope and Manning's friction factor. A slope change of $0.0001 \mathrm{ft} / \mathrm{mi}$ or a 0.005 change in Manning's friction factor resulted in streamflow that had either too much or too little velocity resulting in false traveltimes. This was evident in the timing of the measured changes in streamflow compared to the modeled changes. Simulations were generally insensitive to changes in other hydraulic parameters.

Simulations of water temperature were largely unaffected by changes in associated coefficients. The effects of changes in wind sheltering and resistance coefficients and dynamic shading were not modeled. Simulated water-quality constituents were affected by several of the 88 parameters and coefficients listed in table 11. Most of the parameters were adjusted to values only slightly different than the default values (Cole and Wells, 2003). Parameters that were adjusted outside the range of the default values were compared with values from previous studies (Bales and others, 2001; Galloway and Green, 2002; Berger and others, 2003). Still, other parameters were adjusted to better simulate measured values. 
A. Lecompton, synoptic survey II, February 25-March 1, 2002

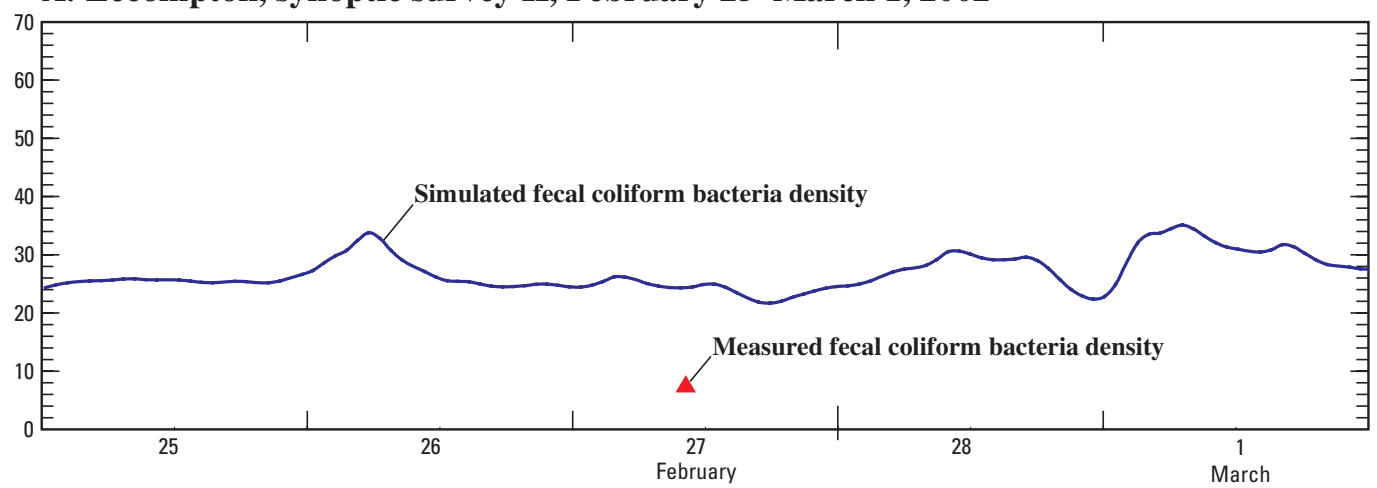

B. DeSoto, synoptic survey II, February 25-March 1, 2002

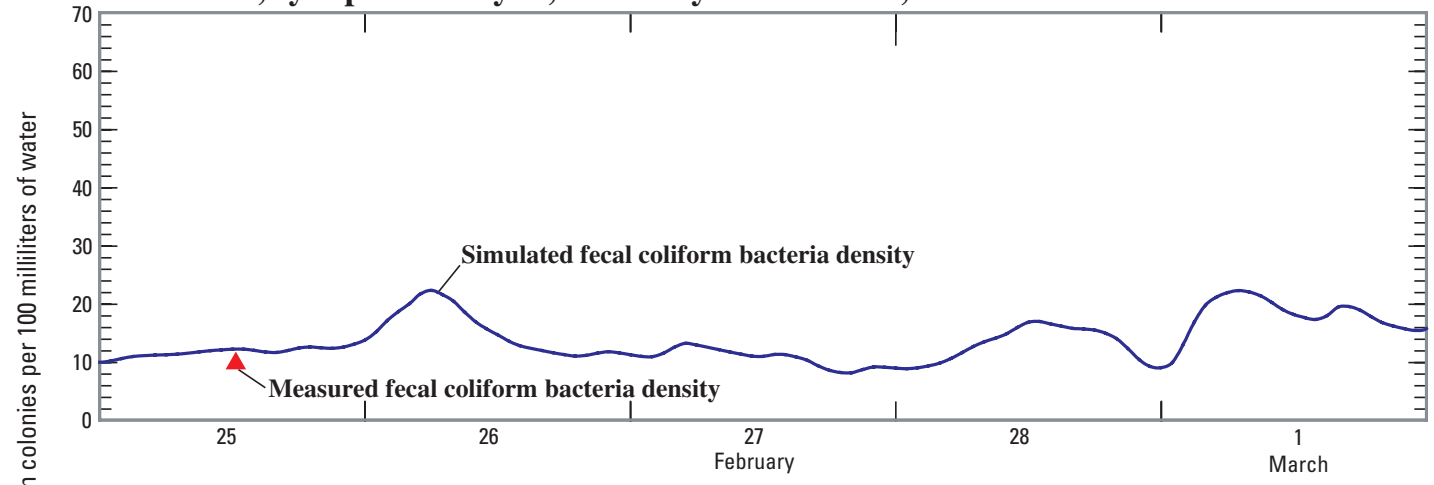

C. Lecompton, synoptic survey III, July 22-August 8, 2002

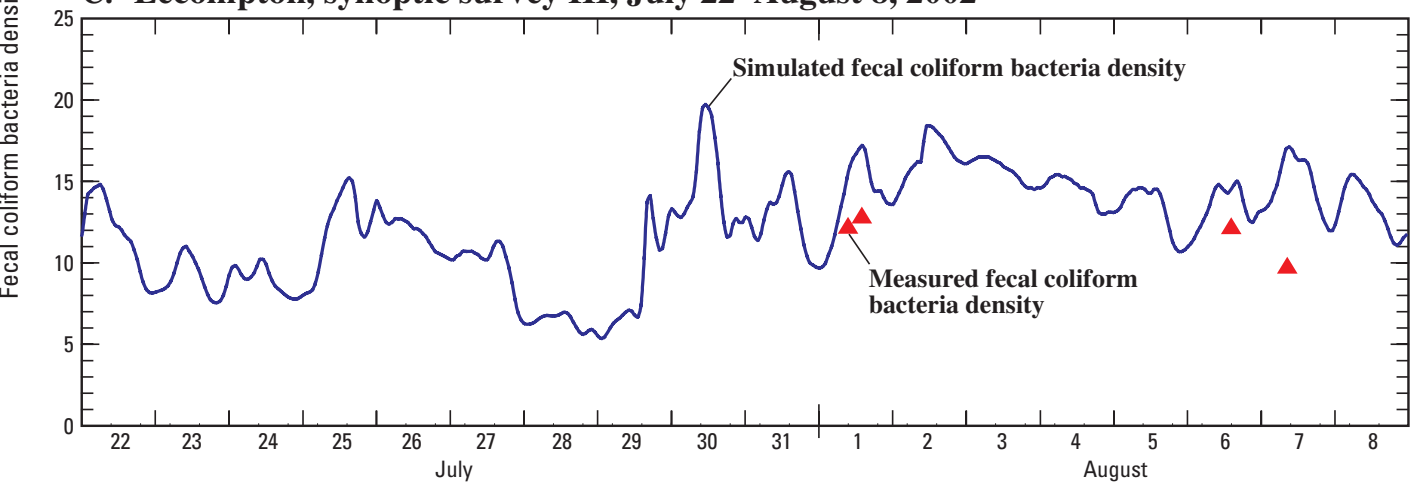

D. DeSoto, synoptic survey III, July 22-August 8, 2002

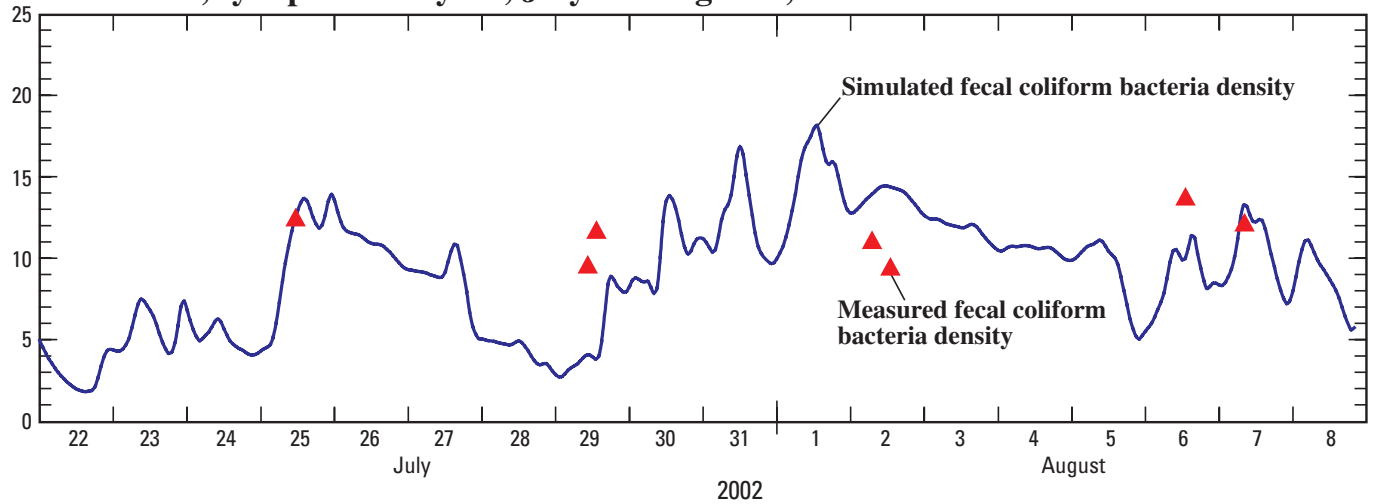

Figure 30. Measured and simulated fecal coliform bacteria densities in Kansas River at Lecompton (site 21) and DeSoto (site 33) for $(A-B)$ synoptic survey II and $(C-D)$ synoptic survey III. Location of sampling sites shown in figure 2. 
Simulated algal concentrations were most sensitive to algal growth rate and the associated temperature coefficients. These parameters were adjusted outside of their default range to so that the simulated algal concentrations would better match the measured concentrations in the winter. Saturation light intensity affected algal concentrations slightly.

Simulated ammonia concentrations were most sensitive to algal concentration changes. The more algae available, the smaller the ammonia concentrations were. Simulated ammonia concentrations were less sensitive to the ammonia decay rate coefficient and its associated temperature coefficients. Simulated ammonia concentrations were affected only slightly by changes in nitrite decay rates and algal preference of ammonia or nitrite.

Simulated fecal coliform bacteria concentrations were affected only by the first-order decay rate (table 11) and settling coefficients. The default value for fecal coliform decay rate was used for these simulations.

\section{Model Limitations}

The model was calibrated on the basis of low-flow conditions measured in the Kansas River and its tributaries during the discrete periods of synoptic surveys II and III. The effects of changing the boundary conditions of the calibrated model are varied depending on which conditons are changed. Adjusting the model so that the streamflow in the Kansas River is much smaller or larger than the streamflows modeled for synoptic surveys II and III could produce results with greater uncertainty. Without measuring the inflow water quality of the Kansas River during hypothetically larger or smaller streamflow conditions, it is impossible to know if the assumed water-quality boundary conditions used in the calibrated model are reasonable enough estimates for the hypothetical simulations. Results of hypothetical adjustment of other boundary conditions such as tributary or WWTFs flows or ammonia concentrations are less uncertain because the inflow Kansas River conditions are unchanged. So if, for example, ammonia concentrations from a WWTF are increased, the model results of the effects in the Kansas River are accurate for those conditions.

\section{Hypothetical Simulations}

The calibrated Kansas River water-quality model was used to describe and evaluate hypothetical conditions. KDHE needed results from four hypothetical simulations using the calibrated model (table 12). The effluent of an additional proposed WWTF and hypothetical alterations to existing WWTF effluent discharges in combination with the existing calibrated model were used to determine the possible effects on water quality in the

Kansas River. All of the hypothetical results were compared to the calibrated model results. Hypothetical simulations were made using boundary conditions from the winter and summer calibrated models with the exceptions of ammonia, nitrite plus nitrate, total phosphorus, orthophosphorus, and carbonaceous biochemical oxygen demand (table 12). All simulated results were cross-sectional averages for noon and midnight on February 27,2002 , and July 31,2002 . The application of the calibrated model to hypothetical situations is valid so long as the hydrologic and meteorologic conditions and WWTF discharge characteristics are similar.

Hypothetical simulations also are provided for situations where the streamflow boundary condition for the Kansas River at Topeka (site 12) was reduced to the 30-day, 10-year low flow (30Q10) of $670 \mathrm{ft}^{3} / \mathrm{s}$. KDHE determines WWTF permitted discharges of ammonia into the Kansas River on the basis of streamflow equal to 30Q10 flows (table 4). Therefore, KDHE needed the calibrated model and the hypothetical simulations also run using the 30Q10 streamflow instead of the streamflow measured in the Kansas River during synoptic surveys II and III. The results of the 30Q10 hypothetical simulations are presented in Appendix 3.

\section{Effects of Hypothetical Simulation 1}

First, the calibrated model was altered so that the effluent discharges from three major main-stem WWTFs were equal to their design flow and current (2005) permitted limit for ammonia (table 12). In comparison to the calibrated results, simulated in-stream ammonia concentrations were usually larger in the hypothetical simulation 1, with the exception of concentrations immediately downstream from the Topeka Oakland WWTF (site 13) in the winter (fig. 31A). Simulated in-stream concentrations were larger for the calibrated model in winter because the ammonia concentration measured at the Topeka Oakland WWTF $(30 \mathrm{mg} / \mathrm{L})$ was 18 times larger than the current permitted limit $(1.6 \mathrm{mg} / \mathrm{L})$. The results from hypothetical simulation 1 were plotted with the results from the other three hypothetical simulations for further comparison (figs. 31-33).

\section{Effects of Hypothetical Simulation 2}

The change for hypothetical simulation 2 was to discharge effluent from a proposed new WWTF that would serve the growing population of Johnson County, Kansas. The design flow for this proposed WWTF was $85 \mathrm{ft}^{3} / \mathrm{s}(55 \mathrm{Mgal} / \mathrm{d})$, more than two times larger than any of the existing WWTF design flows. The simulation was run for winter and summer conditions in two parts: (1) locating the proposed WWTF upstream from DeSoto (river mile 31) and (2) locating the proposed WWTF downstream from Cedar Creek (river mile 25). The two parts of the simulation were necessary to help determine the effects of the proposed WWTF's effluent on the horizontal source-water wells located along the Kansas River near the confluence of Cedar Creek. These wells provide drinking water for the city of Olathe. 
Table 12. Boundary conditions used in CE-QUAL-W2 model for various hypothetical simulations describing possible effects on water quality in Kansas River in northeast Kansas during winter and summer.

[Mgal/d, million gallons per day; $\mathrm{ft}^{3} / \mathrm{s}$, cubic feet per second; $\mathrm{mg} / \mathrm{L}$, milligrams per liter; $\mathrm{n} / \mathrm{a}$, not applicable or not determined]

\begin{tabular}{|c|c|c|c|c|c|c|c|c|c|c|c|}
\hline \multirow{3}{*}{$\begin{array}{c}\text { Map } \\
\text { number } \\
\text { (fig. 2) }\end{array}$} & \multirow{3}{*}{$\begin{array}{l}\text { Wastewater-treatment } \\
\text { facility }\end{array}$} & \multicolumn{3}{|c|}{ Effluent discharge } & \multicolumn{3}{|c|}{ Ammonia concentrations } & \multicolumn{4}{|c|}{ Input concentrations } \\
\hline & & \multirow{2}{*}{$\begin{array}{c}\text { Simulated } \\
\text { (Mgal/d) }\end{array}$} & \multirow[b]{2}{*}{$\begin{array}{l}2004 \text { design } \\
\text { (Mgal/d) }\end{array}$} & \multirow{2}{*}{$\begin{array}{l}\text { Simulated } \\
\left(\mathrm{ft}^{3} / \mathrm{s}\right)\end{array}$} & \multirow[b]{2}{*}{$\begin{array}{l}\text { Simulated } \\
(\mathrm{mg} / \mathrm{L})\end{array}$} & \multicolumn{2}{|c|}{ Design limits } & \multirow{2}{*}{$\begin{array}{l}\text { Nitrite plus } \\
\text { nitrate as } \\
\text { nitrogen } \\
\text { (mg/L) }\end{array}$} & \multirow{2}{*}{$\begin{array}{c}\text { Total } \\
\text { phosphorus } \\
\text { (mg/L) }\end{array}$} & \multirow{2}{*}{$\begin{array}{l}\text { Ortho- } \\
\text { phosphorus } \\
\text { (mg/L) }\end{array}$} & \multirow{2}{*}{$\begin{array}{l}\text { Carbon- } \\
\text { aceous } \\
\text { biochemical } \\
\text { oxygen } \\
\text { demand } \\
\text { (mg/L) }\end{array}$} \\
\hline & & & & & & $\begin{array}{l}\text { Winter } \\
\text { (mg/L) }\end{array}$ & $\begin{array}{c}\text { Summer } \\
\text { (mg/L) }\end{array}$ & & & & \\
\hline
\end{tabular}

Calibration simulation

$\begin{array}{llccc}13 & \text { Topeka Oakland } & 16 & 16 & 15.8 \\ 25 & \text { Lawrence } & 12.5 & 12.5 & 10.5 \\ 44 & \text { Johnson County Mill Creek } & 9 & 9 & 11.6\end{array}$

\section{Winter}

$\begin{array}{llccc}13 & \text { Topeka Oakland } & 16 & 16 & 11.9 \\ 25 & \text { Lawrence } & 12.5 & 12.5 & 9.75 \\ 44 & \text { Johnson County Mill Creek } & 9 & 9 & 10.8\end{array}$

$\begin{array}{ccc}30 & 7.8 & \mathrm{n} / \mathrm{a} \\ 8.8 & 7 & \mathrm{n} / \mathrm{a} \\ 19 & 15 & \mathrm{n} / \mathrm{a} \\ \text { Summer } & & \end{array}$

$\begin{array}{cccc}0.65 & 3.0 & 2.4 & 12 \\ 7.7 & 3.7 & 3.0 & 10 \\ .19 & 3.7 & 2.6 & 17 \\ & & & \\ .2 & 3.6 & 3.1 & 12 \\ 15 & 3.9 & 3.4 & \mathrm{n} / \mathrm{a} \\ 1.8 & 4.3 & 3.9 & 4.2\end{array}$

Hypothetical simulation 1

$\begin{array}{clccc}13 & \text { Topeka Oakland } & 16 & 16 & 25 \\ 25 & \text { Lawrence } & 12.5 & 12.5 & 19 \\ 44 & \text { Johnson County Mill Creek } & 9 & 9 & 14\end{array}$

$\begin{array}{ccccccc}21 & \mathrm{n} / \mathrm{a} & 1.6 & .2 & 3.6 & 3.1 & 12 \\ .2 & \mathrm{n} / \mathrm{a} & 7 & 15 & 3.9 & 3.4 & \mathrm{n} / \mathrm{a} \\ 24 & \mathrm{n} / \mathrm{a} & 36 & 1.8 & 4.3 & 3.9 & 4.2\end{array}$

Hypothetical simulation 2

\begin{tabular}{|c|c|c|c|}
\hline $\mathrm{n} / \mathrm{a}$ & $\begin{array}{l}\text { Proposed DeSoto (river mile } \\
25 \text { or } 31 \text { ) }\end{array}$ & 55 & $\mathrm{n} / \mathrm{a}$ \\
\hline
\end{tabular}

Hypothetical simulation 3

\begin{tabular}{|c|c|c|c|c|c|c|c|c|c|c|c|}
\hline 13 & Topeka Oakland & 16 & 16 & 25 & 1.0 & 7.8 & 1.6 & 1.0 & 2.0 & 1.6 & 10 \\
\hline 25 & Lawrence & 12.5 & 12.5 & 19 & 1.0 & 7 & 7 & 1.0 & 2.0 & 1.6 & 10 \\
\hline 44 & Johnson County Mill Creek & 18.75 & 9 & 29 & 1.0 & 15 & 36 & 1.0 & 2.0 & 1.6 & 10 \\
\hline
\end{tabular}


Table 12. Boundary conditions used in CE-QUAL-W2 model for various hypothetical simulations describing possible effects on water quality in Kansas River in northeast Kansas during winter and summer.-Continued

[Mgal/d, million gallons per day; $\mathrm{ft}^{3} / \mathrm{s}$, cubic feet per second; $\mathrm{mg} / \mathrm{L}$, milligrams per liter; $\mathrm{n} / \mathrm{a}$, not applicable or not determined]

\begin{tabular}{|c|c|c|c|c|c|c|c|c|c|c|c|}
\hline \multirow{3}{*}{$\begin{array}{c}\text { Map } \\
\text { number } \\
\text { (fig. 2) }\end{array}$} & \multirow{3}{*}{$\begin{array}{l}\text { Wastewater-treatment } \\
\text { facility }\end{array}$} & \multicolumn{3}{|c|}{ Effluent discharge } & \multicolumn{3}{|c|}{ Ammonia concentrations } & \multicolumn{4}{|c|}{ Input concentrations } \\
\hline & & \multirow[b]{2}{*}{$\begin{array}{l}\text { Simulated } \\
\text { (Mgal/d) }\end{array}$} & \multirow{2}{*}{$\begin{array}{c}2004 \\
\text { design } \\
(\mathrm{Mgal} / \mathrm{d})\end{array}$} & \multirow[b]{2}{*}{$\begin{array}{l}\text { Simulated } \\
\qquad\left(\mathrm{ft}^{3} / \mathrm{s}\right)\end{array}$} & \multirow[b]{2}{*}{$\begin{array}{l}\text { Simulated } \\
(\mathrm{mg} / \mathrm{L})\end{array}$} & \multicolumn{2}{|c|}{ Design limits } & \multirow{2}{*}{$\begin{array}{l}\text { Nitrite plus } \\
\text { nitrate as } \\
\text { nitrogen } \\
\text { (mg/L) }\end{array}$} & \multirow{2}{*}{$\begin{array}{c}\text { Total } \\
\text { phosphorus } \\
\text { (mg/L) }\end{array}$} & \multirow{2}{*}{$\begin{array}{c}\text { Ortho- } \\
\text { phosphorus } \\
\text { (mg/L) }\end{array}$} & \multirow{2}{*}{$\begin{array}{l}\text { Carbon- } \\
\text { aceous } \\
\text { biochemical } \\
\text { oxygen } \\
\text { demand } \\
\text { (mg/L) }\end{array}$} \\
\hline & & & & & & $\begin{array}{l}\text { Winter } \\
(\mathrm{mg} / \mathrm{L})\end{array}$ & $\begin{array}{c}\text { Summer } \\
\text { (mg/L) }\end{array}$ & & & & \\
\hline \multicolumn{12}{|c|}{ Hypothetical simulation 4} \\
\hline 13 & Topeka Oakland & 16 & 16 & 25 & 1.0 & 1.6 & 7.8 & 1.0 & 2.0 & 1.6 & 10 \\
\hline 25 & Lawrence & 20 & 12.5 & 31 & 1.0 & 7.0 & 7.0 & 1.0 & 2.0 & 1.6 & 10 \\
\hline $\mathrm{n} / \mathrm{a}$ & $\begin{array}{l}\text { Proposed DeSoto (river } \\
\text { mile } 25 \text { or } 31 \text { ) }\end{array}$ & 55 & $\mathrm{n} / \mathrm{a}$ & 85 & 1.0 & $\mathrm{n} / \mathrm{a}$ & $\mathrm{n} / \mathrm{a}$ & 1.0 & 2.0 & 1.6 & 10 \\
\hline 44 & Johnson County Mill Creek & 18.75 & 9.0 & 29 & 1.0 & 36 & 15 & 1.0 & 2.0 & 1.6 & 10 \\
\hline
\end{tabular}


A. Simulated ammonia concentrations, winter conditions

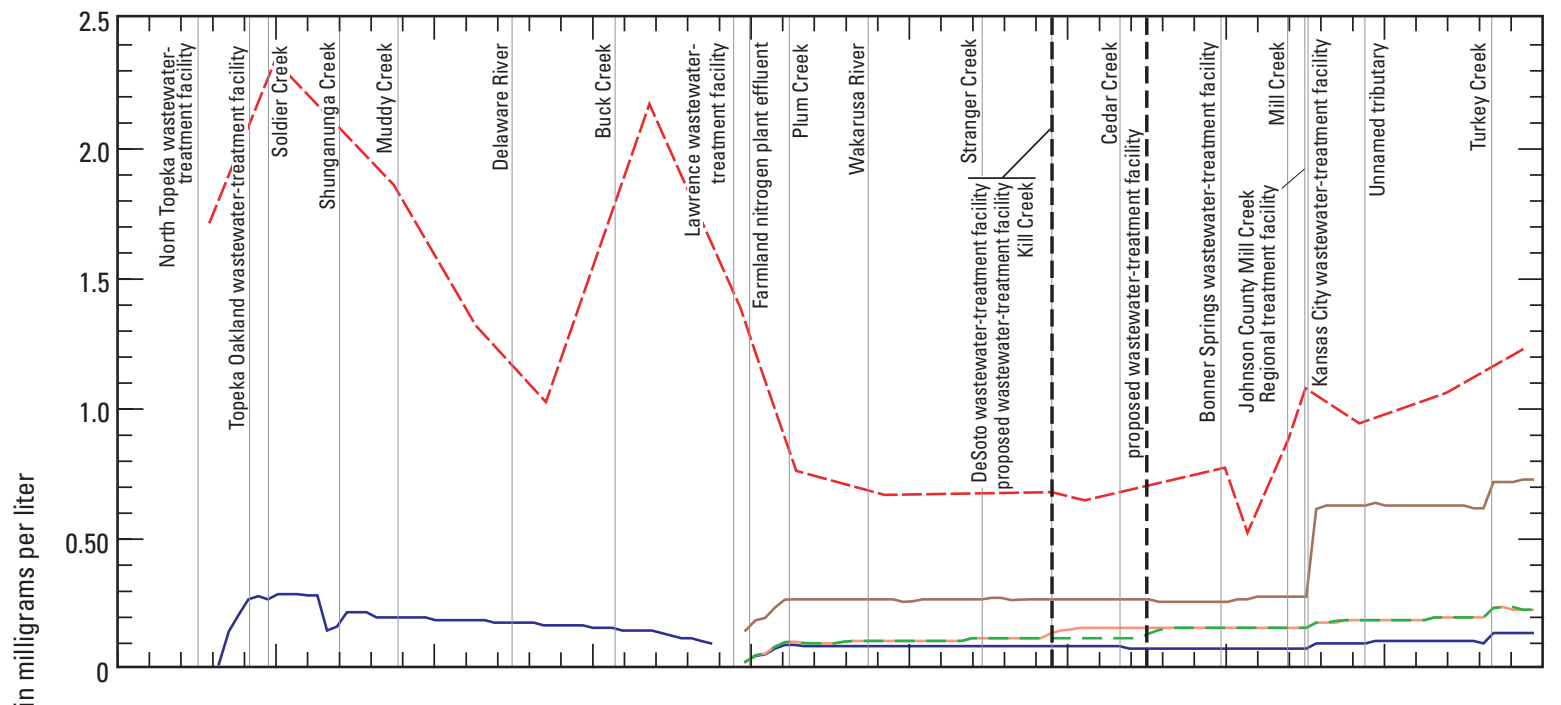

\section{B. Simulated ammonia concentrations, summer conditions}

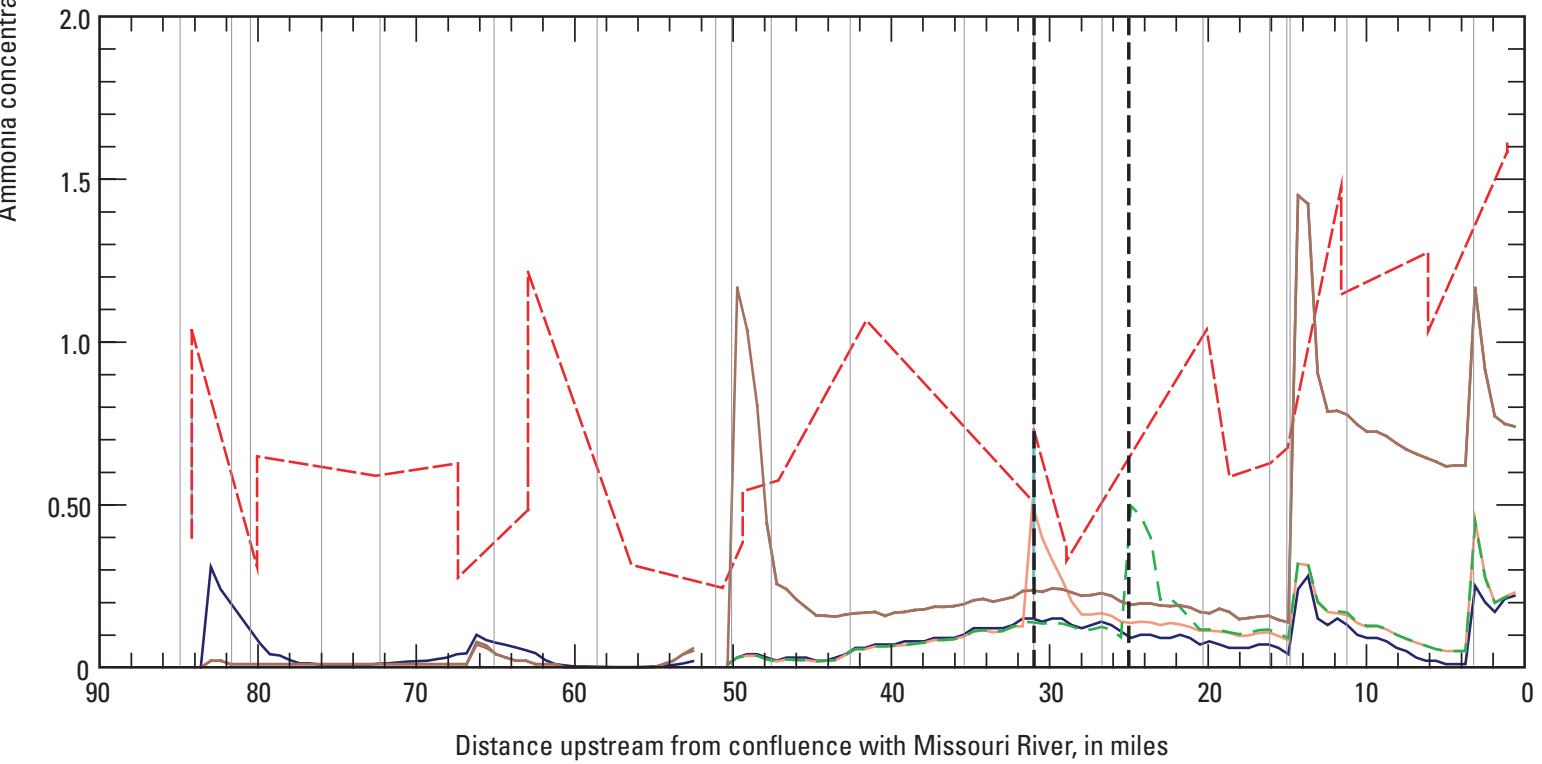

\section{EXPLANATION}

- Simulated ammonia concentrations for the synoptic survey II

- Ammonia concentrations for hypothetical simulation 1

- Ammonia concentrations for hypothetical simulation 2 with proposed treatment facility upstream from Cedar Creek (river mile 31)
- - Ammonia concentrations for hypothetical simulation 2, with proposed treatment facility downstream from Cedar Creek (river mile 25)

- - Chronic aquatic-life criterion with early-life stages of fish present (Kansas Department of Health and Environment, 2002)

Figure 31. Simulated ammonia and dissolved-oxygen concentrations in Kansas River from Topeka to Kansas City during winter and summer low streamflow conditions for calibrated model and hypothetical simulations 1 and 2 . 


\section{Simulated dissolved-oxygen concentrations, winter conditions}

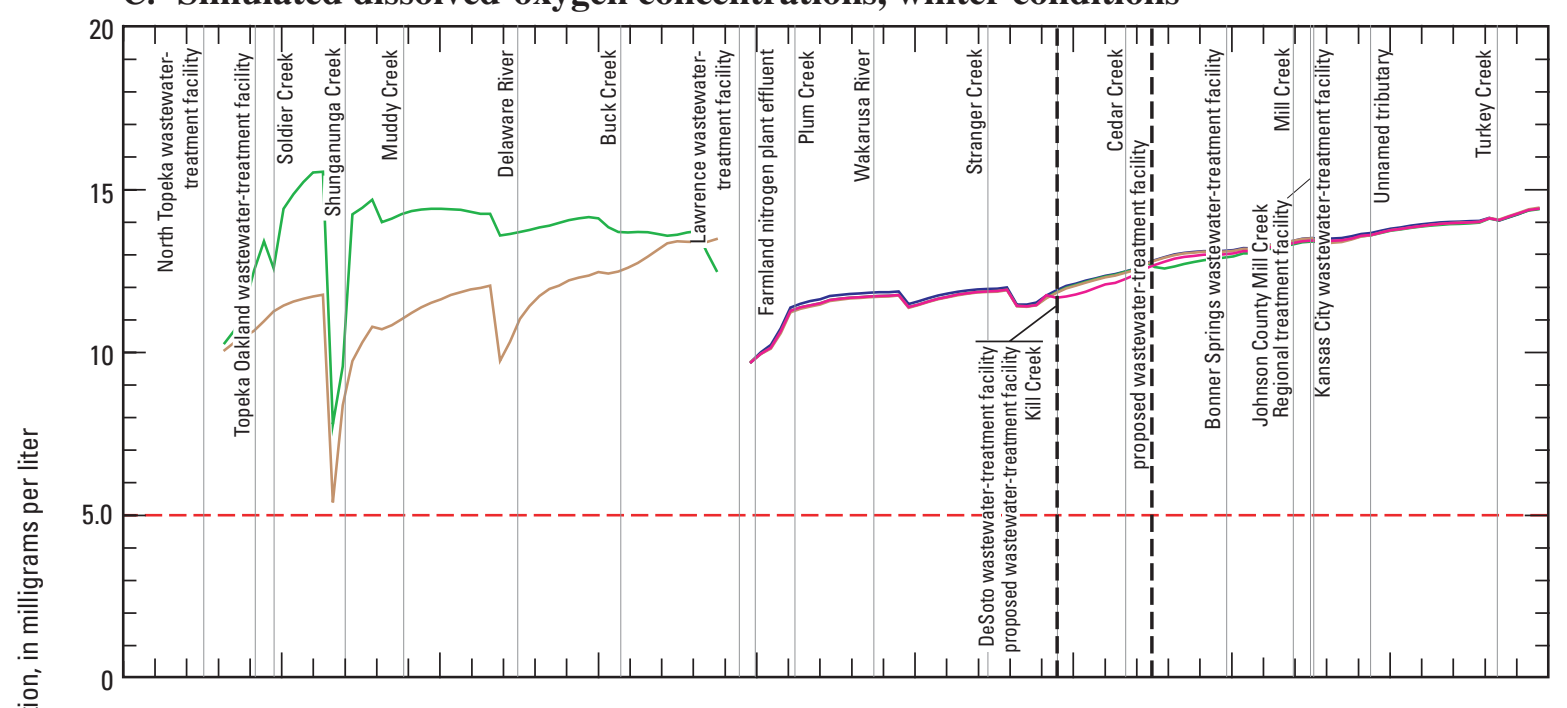

$D$. Simulated dissolved-oxygen concentrations, summer conditions

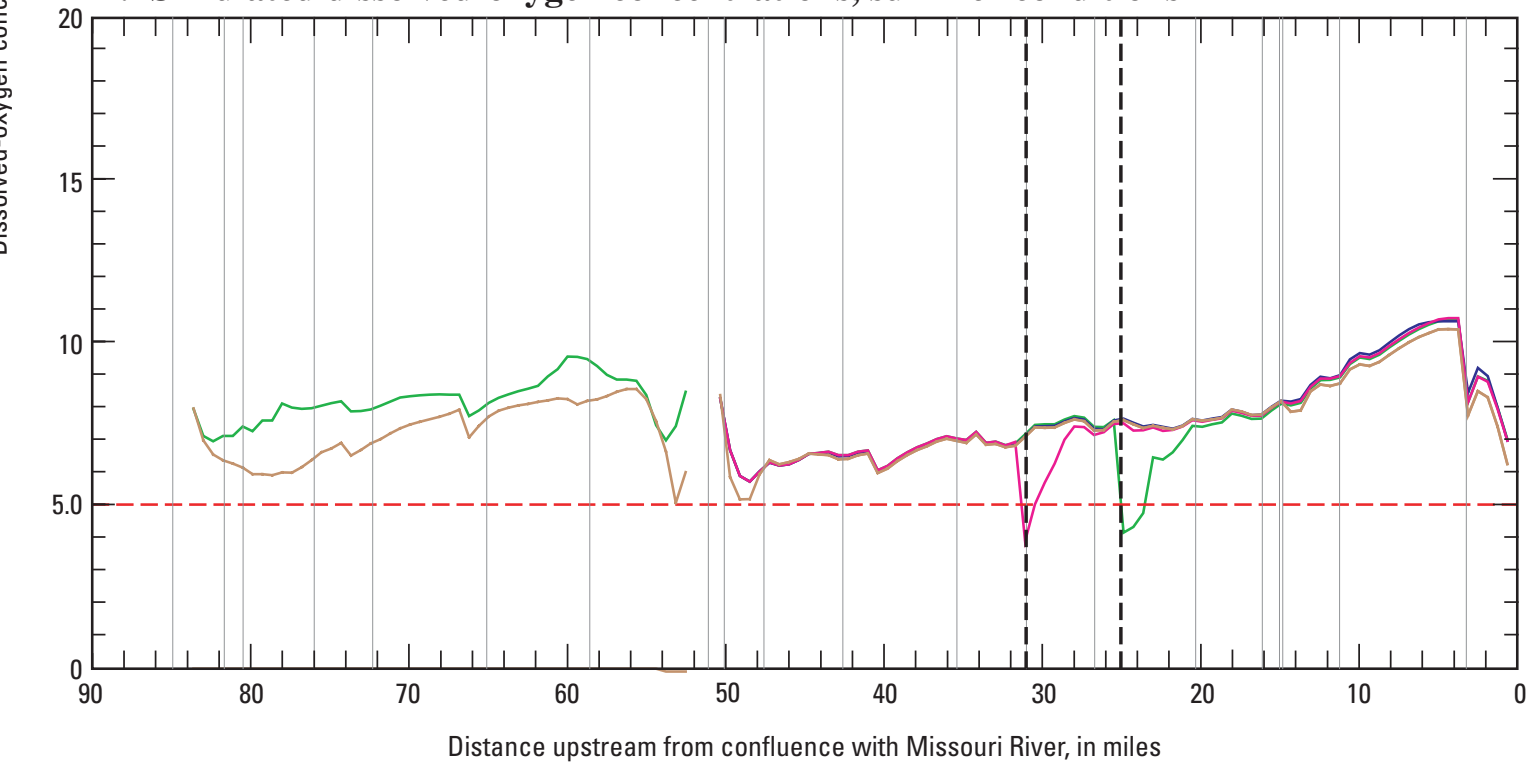

\section{EXPLANATION}

- Simulated dissolved-oxygen concentrations (calibrated model)

— Dissolved-oxygen concentrations for hypothetical simulation 1

- Dissolved-oxygen concentrations for hypothetical simulation 2, with proposed treatment facility upstream from Cedar Creek (river mile 31)
- Dissolved-oxygen concentrations for hypothetical simulation 2, with proposed treatment facility downstream from Cedar Creek (river mile 25)

- - Chronic aquatic-life criterion for dissolved oxygen (Kansas Department of Health and Environment, 2002)

Figure 31. Simulated ammonia and dissolved-oxygen concentrations in Kansas River from Topeka to Kansas City during winter and summer low streamflow conditions for calibrated model and hypothetical simulations 1 and 2 .-Continued 


\section{Hydrologic and Water-Quality Conditions in the Kansas River, Northeast Kansas, November 2001-August 2002}

Results of hypothetical simulation 2, where the addition of the proposed WWTF was upstream from DeSoto or downstream from Cedar Creek, indicated similar increases in ammonia downstream from the proposed WWTF. In the winter, ammonia concentrations downstream from the proposed WWTF indicated similar characteristics but at different locations depending on its hypothetical location (fig. 31A). Results indicated a steady increase in ammonia concentrations in the Kansas River to about $0.04 \mathrm{mg} / \mathrm{L}$ greater than the calibrated results within about $2.5 \mathrm{mi}$ downstream from both hypothetical locations for the proposed WWTF. None of the simulated instream values exceeded the Kansas chronic aquatic-life criteria for early-life stages of fish present. Water temperatures less than $5{ }^{\circ} \mathrm{C}$ minimized nitrification and had little effect on dissolved-oxygen concentrations (fig. 31C). None of simulated dissolved-oxygen concentrations in the winter were less than the Kansas aquatic-life criterion $(5.0 \mathrm{mg} / \mathrm{L})$.

Summer simulations indicated that ammonia concentrations increased substantially for about $5 \mathrm{mi}$ downstream from the proposed WWTF and then maintained a steady concentration slightly greater than the concentrations for calibrated results (fig. $31 B$ ). The maximum simulated main-stem values for both proposed WWTF locations were within $0.2 \mathrm{mg} / \mathrm{L}$ of the Kansas chronic aquatic-life criterion for early-life stages of fish present. As a result of the increased ammonia concentrations, main-stem nitrification suppressed dissolved-oxygen concentrations to less than the Kansas aquatic-life criterion $(5.0 \mathrm{mg} / \mathrm{L})$ for 1 to $2 \mathrm{mi}$ downstream from the proposed WWTF (fig. 31D).

\section{Effects of Hypothetical Simulation 3}

As requested by KDHE, changes to the calibrated model for hypothetical simulation 3 were adjustments to three major WWTFs (Topeka Oakland, Lawrence, and Mill Creek) current design flows and permitted limits for ammonia (Appendix 2). In most cases, this meant that the magnitude of the effluent flow was increased and the concentration of ammonia was decreased from the WWTF values measured and used in the calibrated model.

Results for hypothetical simulation 3 indicated that ammonia concentrations gradually increased from upstream to downstream along the Kansas River during winter and summer. Ammonia concentrations ranged from 0.01 to $0.20 \mathrm{mg} / \mathrm{L}$ in the winter and from 0.03 to $0.27 \mathrm{mg} / \mathrm{L}$ during the summer (figs. $32 \mathrm{~A}$ and $32 B$ ). In-stream ammonia concentrations incrementally increased downstream from each major WWTF. Ammonia concentration increased the most downstream from the Turkey Creek confluence (river mile 3.2). Nelson WWTF discharges into Turkey Creek just upstream from the confluence. The ammonia concentration of Turkey Creek (site 49, fig. 2) just downstream from the Nelson WWTF effluent (site 37, fig. 9) was not changed from the concentration used in the calibrated model and was the largest ammonia concentration of all the WWTF effluents for hypothetical simulation 3. Main-stem ammonia concentrations for hypothetical simulation 3 did not exceed the Kansas chronic aquatic-life criterion for early-life stages of fish present.

Concentrations of dissolved oxygen for the hypothetical simulation 3 were similar to the dissolved-oxygen concentrations reported from the original calibrated model during both winter and summer (fig. $32 C$ and $32 D$ ). None of the simulated main-stem dissolved-oxygen concentrations were less than the Kansas aquatic-life criterion $(5.0 \mathrm{mg} / \mathrm{L})$.

\section{Effects of Hypothetical Simulation 4}

Adjustments to the calibrated model for hypothetical simulation 4 were a combination of adjustments from hypothetical simulations 1 and 2. Effluent from a proposed new WWTF was added to discharge in the Kansas River just downstream from the Cedar Creek confluence (river mile 25), and the design flows and ammonia concentrations for three major WWTFs (Topeka Oakland, Lawrence, Johnson County Mill Creek) were adjusted to the same values as in hypothetical simulation 2. All values for the other WWTFs were the same as the values used for the calibrated model.

Simulated results for hypothetical simulation 4 indicated main-stem concentrations of ammonia similar to those simulated for hypothetical simulation 3 , with the exception of the concentrations found downstream from the proposed WWTF (fig. $33 A$ and $33 B$ ). In the summer, the simulated results indicated that the proposed WWTF would have a profound effect on ammonia and dissolved-oxygen concentration for about $3 \mathrm{mi}$ downstream from its hypothetical location (fig. $33 B$ and $33 D$ ). Ammonia concentrations remained slightly larger than the concentrations in hypothetical simulation 2 until about river mile 10 , where they were approximately equal. Main-stem ammonia concentrations were equal to or less than those simulated with the calibrated model except near the Lawrence and proposed WWTFs. Summer simulated ammonia concentrations near the proposed WWTF were the closest that any of the simulated values got to the Kansas chronic aquatic-life-support criterion for early-life stages of fish present.

Concentrations of dissolved oxygen for hypothetical simulation 4 were similar to the dissolved-oxygen concentrations reported from the original calibrated model during both winter and summer with some exceptions (fig. $33 C$ and 33D). During the winter, downstream from the proposed new WWTF (river mile 25), simulated dissolved-oxygen concentrations decreased slightly (about $0.5 \mathrm{mg} / \mathrm{L}$ ) and gradually increased over the next $5 \mathrm{mi}$ to levels identical to the calibrated model. During the summer, simulated dissolved-oxygen concentrations downstream from the Lawrence WWTF (river mile 50) decreased to $5.0 \mathrm{mg} / \mathrm{L}$ before increasing gradually over the next $3 \mathrm{mi}$ to concentrations similar to the calibrated model. Also, simulated dissolved-oxygen concentrations downstream from the hypothetical WWTF (river mile 25) decreased to concentrations that were less than the Kansas aquatic-life criterion $(5.0 \mathrm{mg} / \mathrm{L})$, reaching a minimum of about $4 \mathrm{mg} / \mathrm{L}$ before increasing over the next 4 mi back to the levels similar to the calibrated model. 
A. Simulated ammonia concentrations, winter conditions

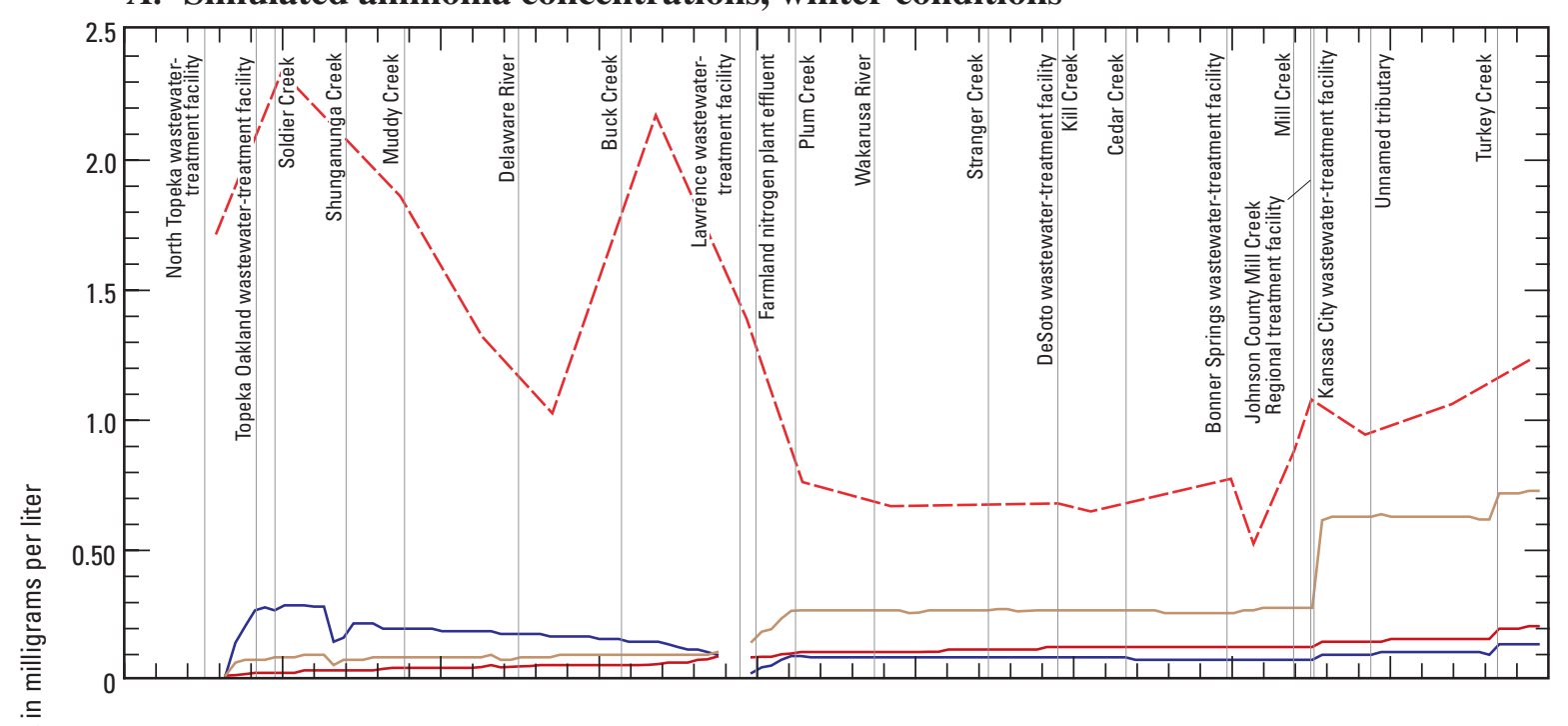

\section{B. Simulated ammonia concentrations, summer conditions}

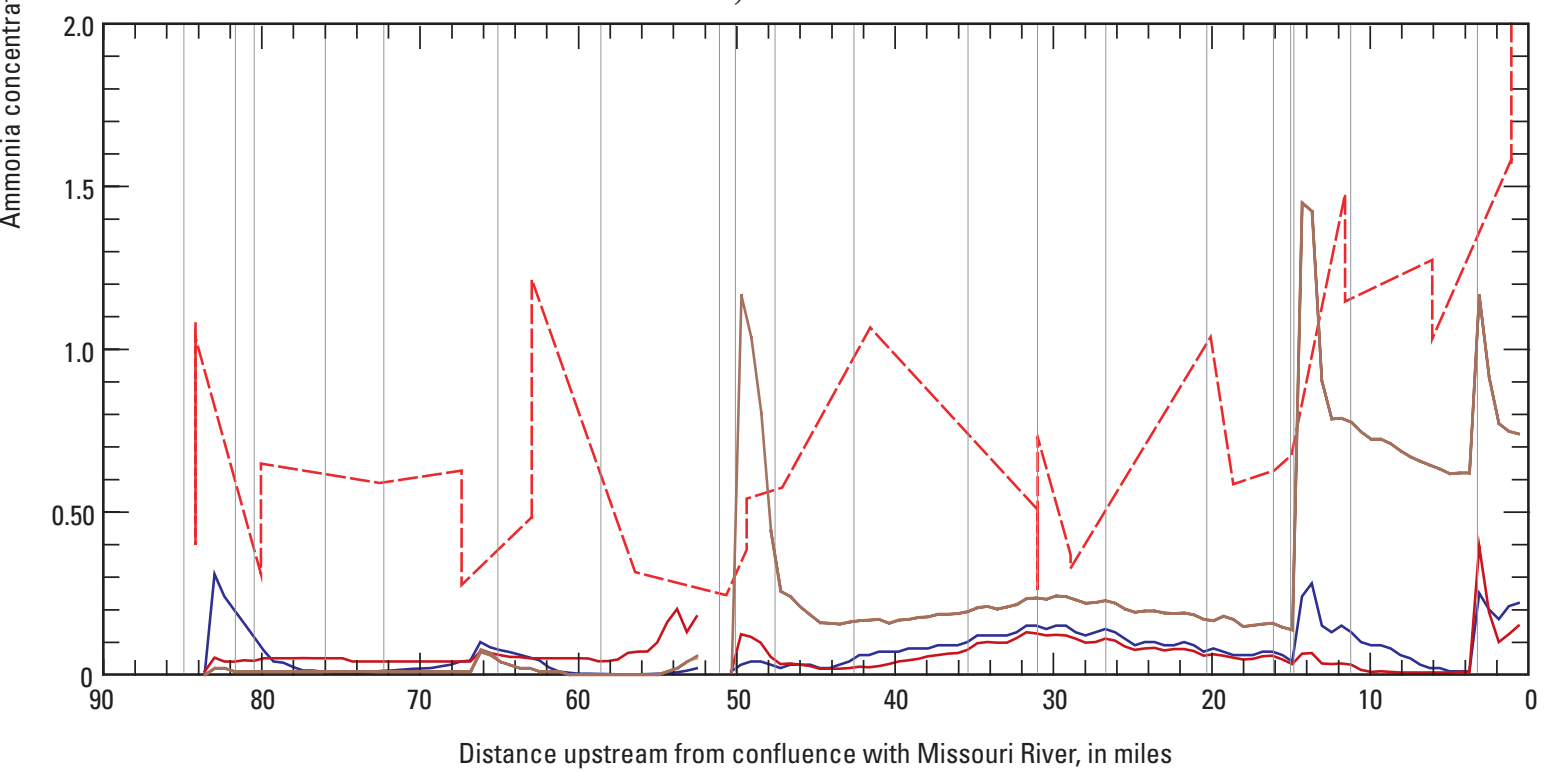

\section{EXPLANATION}

- Simulated ammonia concentrations (calibrated model)

- Ammonia concentrations for hypothetical simulation 1
- Ammonia concentrations for hypothetical simulation 3

- - Chronic aquatic-life criterion with early-life stages of fish present (Kansas Department of Health and Environment, 2002)

Figure 32. Simulated ammonia and dissolved-oxygen concentrations in Kansas River from Topeka to Kansas City during winter and summer low streamflow conditions for calibrated model and hypothetical simulations 1 and 3 . 


\section{Simulated dissolved-oxygen concentrations, winter conditions}

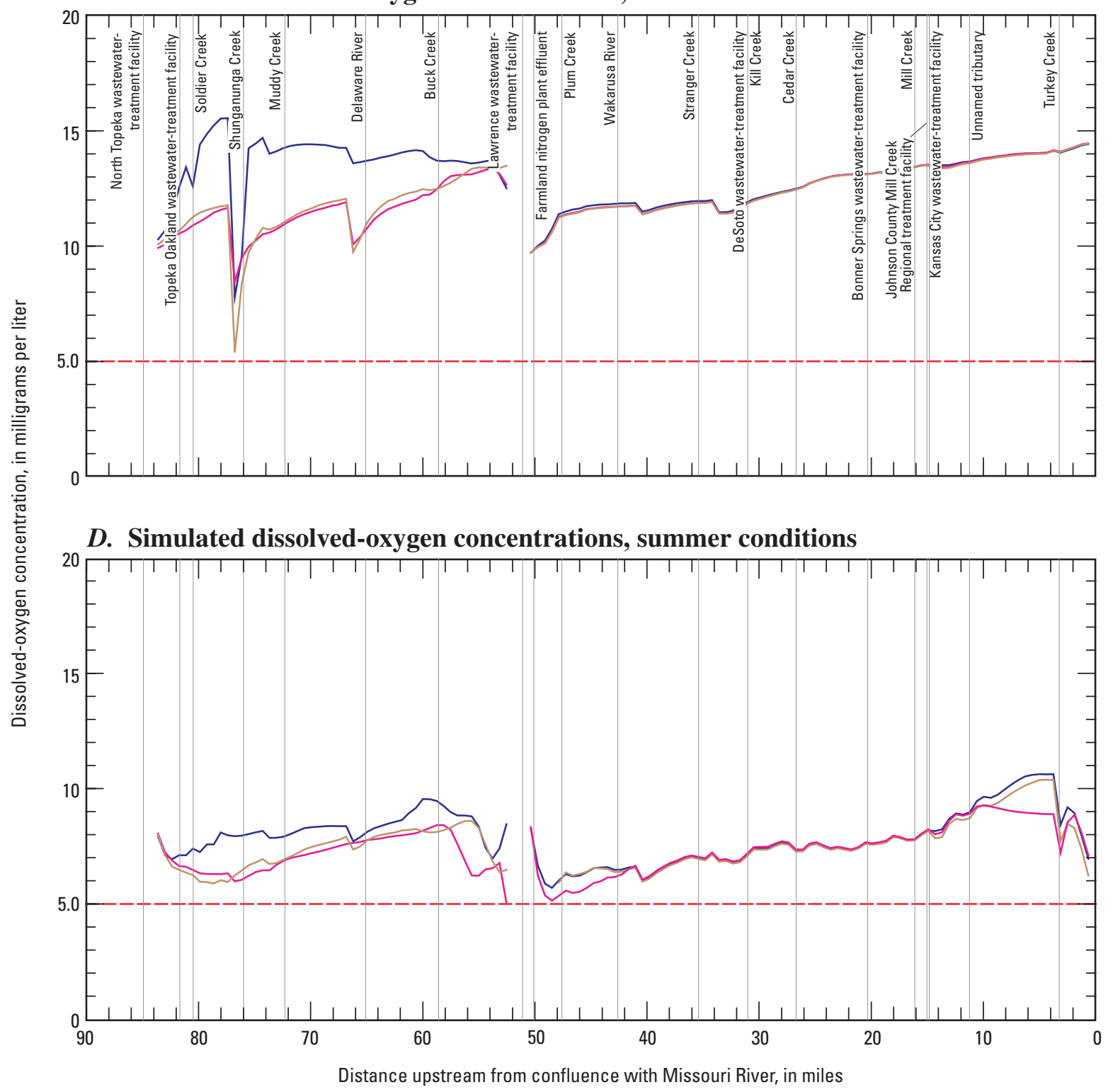

EXPLANATION

- Simulated dissolved-oxygen concentrations (calibrated model)

- Dissolved-oxygen concentrations for hypothetical simulation 1
- Dissolved-oxygen concentrations for hypothetical simulation 3

--Chronic aquatic-life criterion for dissolved oxygen (Kansas Department of Health and Environment, 2002)

Figure 32. Simulated ammonia and dissolved-oxygen concentrations in Kansas River from Topeka to Kansas City during winter and summer low streamflow conditions for calibrated model and hypothetical simulations 1 and 3.-Continued 
A. Simulated ammonia concentrations, winter conditions

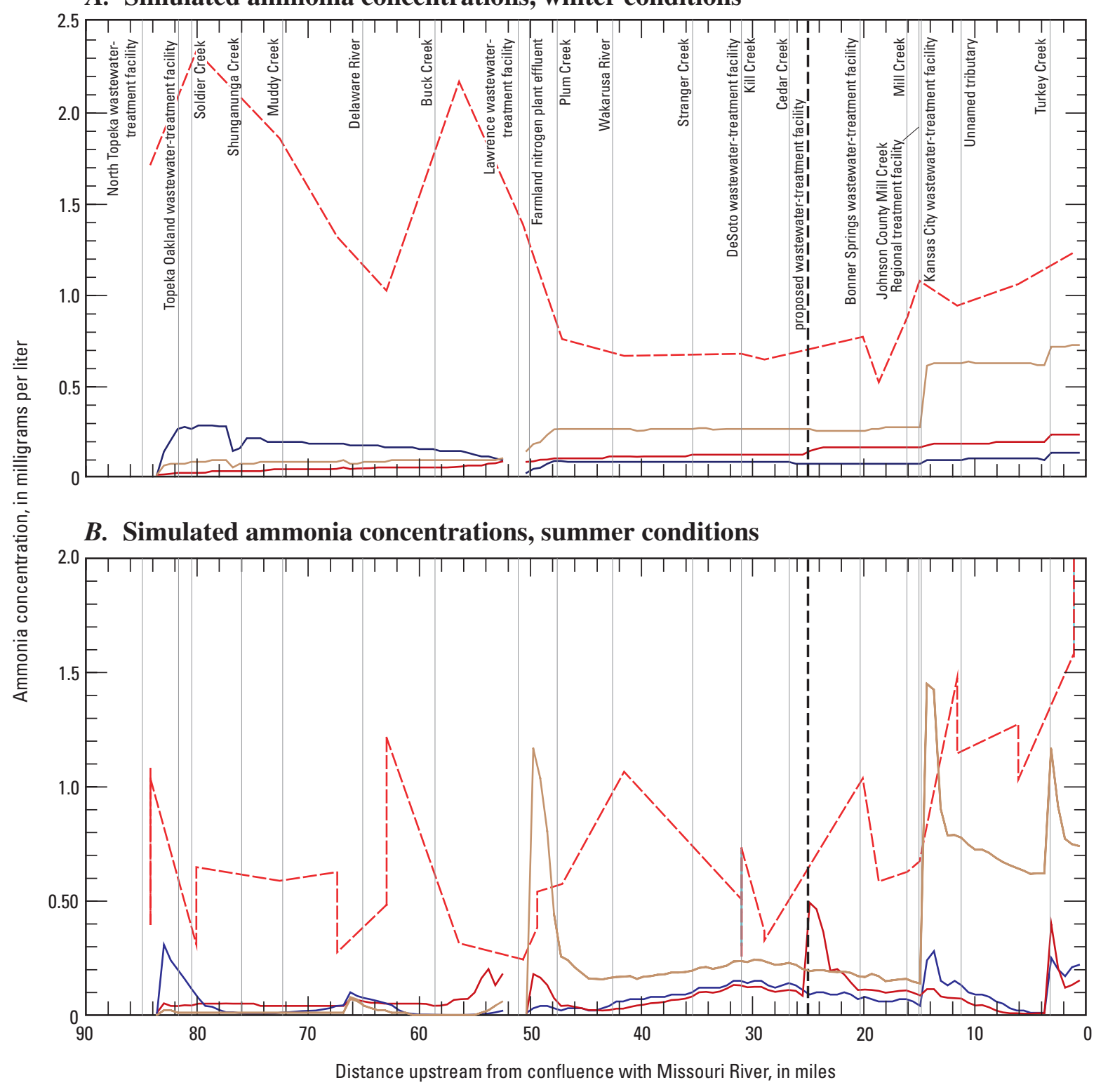

EXPLANATION

- Simulated ammonia concentrations (calibrated model)

- Ammonia concentrations for hypothetical simulation 1
- Ammonia concentrations for hypothetical simulation 4

-- Chronic aquatic-life criterion with early-life stages of fish present (Kansas Department of Health and Environment, 2002)

Figure 33. Simulated ammonia and dissolved-oxygen concentrations in Kansas River from Topeka to Kansas City during winter and summer low streamflow conditions for calibrated model and hypothetical simulations 1 and 4 . 
C. Simulated dissolved-oxygen concentrations, winter conditions

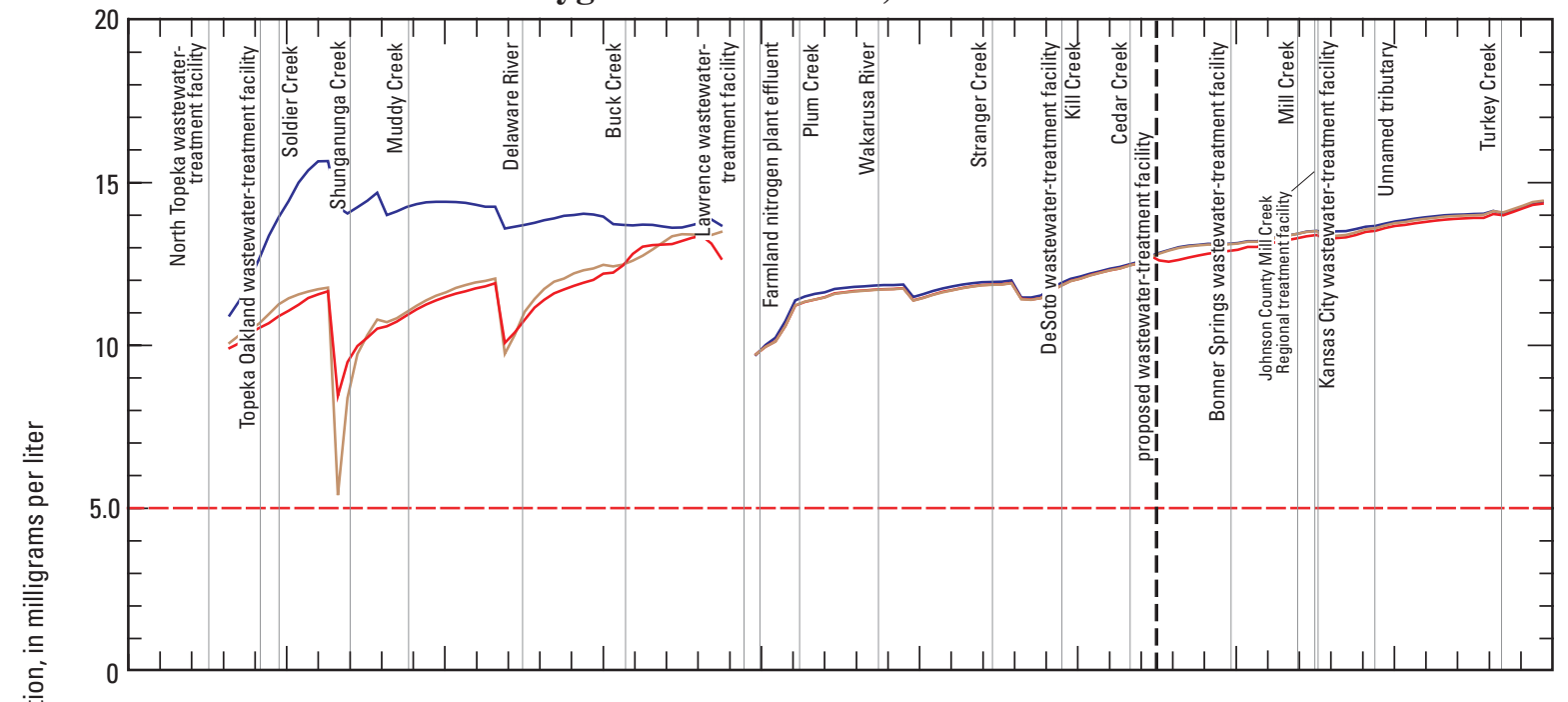

$D$. Simulated dissolved-oxygen concentrations, summer conditions

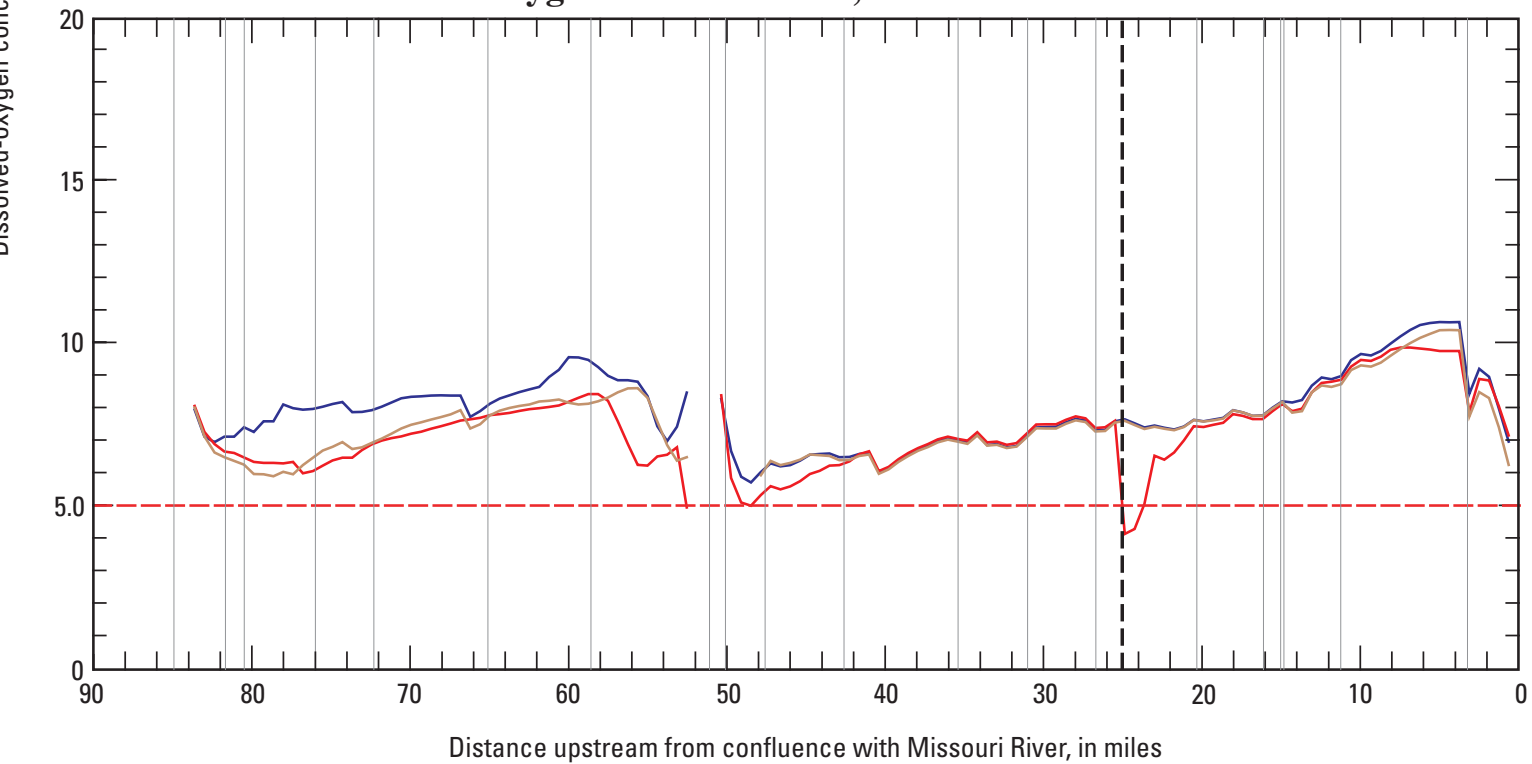

\section{EXPLANATION}

- Simulated dissolved-oxygen concentrations (calibrated model)

— Dissolved-oxygen concentrations for hypothetical simulation 1
- Dissolved-oxygen concentrations for hypothetical simulation 4 , with proposed treatment facility downstream from Cedar Creek (river mile 25)

- - Chronic aquatic-life criterion for dissolved oxygen (Kansas Department of Health and Environment, 2002)

Figure 33. Simulated ammonia and dissolved-oxygen concentrations in Kansas River from Topeka to Kansas City during winter and summer low streamflow conditions for calibrated model and hypothetical simulations 1 and 4 . - Continued 


\section{Summary and Conclusions}

Nutrients and bacteria are two of the most common waterquality contaminants in Kansas and are responsible for causing stream segments to be designated as water-quality impaired. The Kansas Department of Health and Environment (KDHE) has listed the Kansas River in northeast Kansas as water-quality limited with respect to ammonia and fecal coliform bacteria. Once a stream has been designated as water-quality limited and appears on the water-quality limited (303d) list, the Federal Clean Water Act requires that States establish total maximum daily loads to meet those water-quality criteria. Treatment facility upgrades and best management practices within the watershed are possible solutions for improving water quality.

Concentrations of ammonia and fecal coliform bacteria associated with wastewater-treatment facility (WWTF) effluent from areas of rapid population growth and urban development are a particular concern along the Kansas River between Topeka and Kansas City. Large concentrations of ammonia during low streamflow conditions are of concern in this reach of the Kansas River. Large densities of fecal coliform bacteria indicate elevated risks of contracting human diseases for those using the stream. As urban growth continues along the Kansas River, capacities of existing WWTFs will increase, and new WWTFs will discharge to the Kansas River.

In July 2000, the U.S. Geological Survey (USGS), in cooperation with KDHE and support from the U.S. Environmental Protection Agency, conducted an investigation of the Kansas River in northeast Kansas to characterize and simulate waterquality conditions during low streamflow conditions. Three synoptic surveys were undertaken in November 2001 and February and July 2002. A total of 147 water samples were collected at 50 sites within and along the Kansas River between Wamego and Kansas City, Kansas. Water-quality monitors installed in the Kansas River at selected sites provided hourly measurements of specific conductance, $\mathrm{pH}$, water temperature, turbidity, and dissolved oxygen during synoptic survey III (summer 2002). Results from discrete sample collection and hourly measurements were used to calibrate and verify a twodimensional water-quality model of the Kansas River.

Results from the samples collected during the three synoptic surveys indicated that WWTFs along the Kansas River increased ammonia concentrations and bacteria densities in the river during low streamflow conditions. The largest increases in ammonia concentrations on the main-stem Kansas River were detected immediately downstream from the Topeka Oakland WWTF, the Lawrence WWTF, and the Johnson County Mill Creek WWTF. The largest ammonia concentration $(0.27 \mathrm{mg} / \mathrm{L})$ on the main-stem Kansas River occurred just downstream from the Topeka Oakland WWTF and was less than the State of Kansas $\mathrm{pH}$ - and temperature-dependent chronic aquatic-life criterion for ammonia $(0.30 \mathrm{mg} / \mathrm{L})$. Ammonia concentrations in 67 percent of the main-stem samples collected during the third synoptic survey (summer conditions) were less than the laboratory reporting level, whereas none of the concentrations in samples collected during the second synoptic survey (winter conditions) were. Overall, ammonia concentrations in the Kansas River, its tributaries, and WWTF effluent were larger during the winter than during the summer. None of the main-stem sample concentrations exceeded the State of Kansas pH- and temperature-dependent chronic aquatic-life criteria for ammonia. The temporal variance defined by the results of synoptic survey III indicated that ammonia concentrations in the Kansas River sometimes varied hourly by differences of as much as 155 percent. Other nutrient constituents, such as total nitrogen and total phosphorus, indicated a similar but muted spatial pattern along the main stem of the Kansas River with concentrations increasing slightly downstream from major WWTFs.

Samples analyzed for densities of fecal coliform bacteria illustrate a spatial pattern slightly different from that of the nutrient constituents. Increased densities of bacteria were detected along the main stem downstream from major WWTFs. For instance, during synoptic surveys II and III, fecal coliform bacteria densities downstream from the Lawrence WWTF were more than an order of magnitude greater than upstream densities. The only fecal coliform bacteria density in the main-stem samples to exceed the former State water-quality, single-sample criterion $(2,000 \mathrm{col} / 100 \mathrm{~mL})$ was measured during synoptic survey III in the Kansas River upstream from the Missouri River confluence (site 50) at 4,000 col/100 mL. Temporal variation measured during synoptic survey III indicated up to a 263-percent difference in densities during a 12-day period. Overall, fecal coliform bacteria densities were slightly larger during the summer.

The results from the three synoptic surveys indicated that concentrations of nutrients and densities of fecal coliform bacteria during low streamflow conditions varied spatially and temporally and increased downstream from major point-source (WWTF) discharges. Concentrations and densities were relatively small at the sampling sites upstream from Topeka. Variability of concentrations and densities was largest from Topeka to the confluence with the Missouri River where WWTFs had a substaintial effect on main-stem water quality. The Kansas River's assimilative process for ammonia typically decreased the concentrations of ammonia downstream from WWTFs. The assimilative process was about twice as effective during the summer synoptic survey than it was during the winter survey. Decay of fecal coliform bacteria was less evident and appeared to have little seasonal effect on the basis of data collected for this report.

Measured loads for ammonia and bacteria were computed to determine primary inputs to the Kansas River. The Oakland WWTF in Topeka was the largest contributor of both ammonia and bacteria on the basis of samples collected during the three synoptic surveys except for fecal coliform bacteria during synoptic survey III when the DeSoto WWTF was discharging the largest load of bacteria. Estimated loads for the main stem were computed and compared to the measured loads to help determine if the synoptic survey sampling schemes adequately represented the water-quality of the river system. 


\section{Hydrologic and Water-Quality Conditions in the Kansas River, Northeast Kansas, November 2001-August 2002}

None of the measured ammonia concentrations in the Kansas River were greater than the State of Kansas criteria. However, two measurements of dissolved oxygen at sampling sites nearest to the Missouri River were less than the State's aquaticlife-support use criterion $(5.0 \mathrm{mg} / \mathrm{L})$ during the summer. Low streamflow conditions in the summer are more suitable for nitrification and the decay of organic matter that consume oxygen. Therefore, the more ammonia available during these conditions, the more dissolved oxygen is consumed, and the greater the risk to aquatic life.

A two-dimensional, laterally averaged hydrodynamic and water-quality model, CE-QUAL-W2 version 3.1, was applied to the Kansas River. The model was calibrated and tested using data from three synoptic surveys conducted between November 2001 and August 2002.

Simulated hourly streamflow, water temperature, and dissolved-oxygen concentrations were compared with measured hourly streamflow, water temperature, and dissolved oxygen in the Kansas River at Topeka and DeSoto. Channel bathymetry, hydraulic and thermal parameters, and rate coefficients were adjusted to calibrate the model to minimize the difference between the measured and simulated hourly values.

Simulated main-stem ammonia concentrations were compared to measured concentrations from upstream to downstream along the Kansas River. The simulated main-stem ammonia concentrations mostly overestimated the measured values for both winter and summer, with a few exceptions. Comparisons between measured and simulated main-stem ammonia concentrations indicated that ammonia concentrations were more accurately simulated during the summer than during the winter. A possible explanation for the large discrepancies between the measured and simulated ammonia concentrations is that the data used in the model were insufficient in defining the system, causing the model to underestimate the actual mainstem nitrification. Another explanation is that measured values from samples were collected over a period of days and the simulated concentration represented a single point in time.

The calibrated Kansas River water-quality model was adjusted and used to describe and evaluate four hypothetical simulations needed by KDHE. Simulation 1 was used to indicate the water quality of the Kansas River if the three major WWTFs were discharging their design flow and maximum permitted ammonia. Other hypothetical simulations described the effects of an additional proposed WWTF at two different locations (simulation 2), hypothetical alterations to existing WWTF effluent discharges (simulation 3), and the effects of combining both hypothetical conditions (simulation 4) were used to determine the possible effects on water quality in the Kansas River. All of the results from the four hypothetical simulations were compared to the calibrated model results for synoptic surveys II (winter) and III (summer). Seasonal comparisons were made between winter and summer simulations.

First, the calibrated model was altered so that the effluent discharges from three major main-stem WWTFs were equal to their design flow and current permitted limit for ammonia. In comparison to the calibrated results, simulated in-stream ammonia concentrations were usually larger in simulation 1, with the exception of concentrations immediately downstream from the Topeka Oakland WWTF (site 13) in the winter. Simulated in-stream concentrations were larger for the calibrated model because the ammonia concentration measured at the Topeka Oakland WWTF was 18 times larger than the current permitted limit.

The results of hypothetical simulation 2 with an additional proposed WWTF at two locations near DeSoto indicated increases in ammonia downstream from the proposed WWTF. The simulation was done in two parts to evaluate effects for the proposed WWTF at two different locations. In the winter, ammonia concentrations downstream from the proposed WWTF indicated a steady increase slightly greater than the calibrated model results. Summer simulation 2 indicated ammonia concentrations increased substantially, and dissolved-oxygen concentrations decreased to less than State of Kansas aquaticlife-support use criterion of $5.0 \mathrm{mg} / \mathrm{L}$ for about 1 to $2 \mathrm{mi}$ downstream from the proposed WWTF and then maintained a steady concentration to the confluence with the Missouri River. These simulated main-stem ammonia concentrations were close to the Kansas chronic aquatic-life criteria for early-life stages of fish present.

In hypothetical simulation 3, changes to hypothetical simulation 1 were made to adjust the design flows from three major WWTFs (Topeka Oakland, Lawrence, and Mill Creek) and permitted ammonia limits. In most cases, this meant that the magnitude of the effluent flow was increased (beyond 2005 design flows) and the concentration of ammonia was decreased from WWTF permitted values used in hypothetical simulation 1. Hypothetical values for nitrite plus nitrate, orthophosphorus, and carbonaceous biochemical oxygen demand also were used in place of the measured values that were used in the calibrated simulation for the three WWTFs. Simulated results for hypothetical simulation 3 indicated that ammonia concentrations were equal to or slightly less than the simulated concentrations from the calibrated model during both winter and summer. None of the simulated main-stem ammonia and dissolved-oxygen concentrations for hypothetical simulation 3 were larger than the Kansas chronic aquatic-life criteria for early-life stages of fish present or less than the Kansas aquaticlife criterion for dissolved oxygen $(5.0 \mathrm{mg} / \mathrm{L})$, respectively.

Simulated results for hypothetical simulation 4 , a combination of hypothetical simulations 2 and 3, indicated in-stream concentrations of ammonia similar to those simulated for hypothetical simulation 3, with the exception of the concentrations found downstream from the proposed WWTF. Hypothetical simulation 4 indicated that ammonia concentrations for winter and summer were equal to or less than those simulated with the calibrated model except near the Lawrence WWTF and the proposed WWTF. Simulated main-stem ammonia and dissolvedoxygen concentrations downstream from the proposed WWTF were close to the Kansas chronic aquatic-life criteria for earlylife stages of fish present and less than the Kansas aquatic-life criterion for dissolved oxygen $(5.0 \mathrm{mg} / \mathrm{L})$, respectively. 


\section{References Cited}

American Public Health Association, American Water Works Association, and Water Environment Federation,1992, Standard methods for the examination of water and wastewater (18th ed.): Washington, D.C., American Public Health Association, p. 2-8 to 2-11.

Bales, J.D., Sarver, K.M., and Giorgino, M.J., 2001, Mountain Island Lake, North Carolina - analysis of ambient conditions and simulation of hydrodynamics, constituent transport, and water-quality characteristics, 1996-97: U.S. Geological Survey Water-Resources Investigations Report 01-4138, $85 \mathrm{p}$.

Berger, C.J., Annear, R.L., Jr., and Wells, S.A., 2003, Upper Spokane river model-model calibration, 2001: Portland, Oregon, Department of Civil and Environmental Engineering, Portland State University, Technical Report EWR-1-03, $89 \mathrm{p}$.

Chapra, S.C., 1997, Surface water-quality modeling: Boston, Massachusetts, McGraw-Hill, 844 p.

Christensen, V.G., Jian, Xiaodong, and Ziegler, A.C., 2000, Regression analysis and real-time water-quality monitoring to estimate constituent concentrations, loads, and yields in the Little Arkansas River, south-central Kansas, 1995-99: U.S. Geological Survey Water-Resources Investigations Report 00-4126, 36 p.

Cole, T.M., and Wells, S.A., 2003, CE-QUAL-W2-a twodimensional, laterally averaged, hydrodynamic and water quality model, version 3.1: Vicksburg, Mississippi, U.S. Army Engineering and Research Development Center, Instruction Report EL-03-1, 619 p.

Daly, C., Taylor, C.H., and Gibson, W.P., 1997, The PRISM approach to mapping precipitation and temperature, in Reprints of 10th Conference on Applied Climatology, Reno, Nevada: American Meteorological Society, p. 10-12.

Dufour, A.P., 1977, Escherichia coli-the fecal coliform, in Hoadley, A.W., and Dutka, B.J., eds., Bacterial indicators/health hazards associated with water, 1977: American Society for Testing and Materials, ASTM STP 635, p. 48-58.

Eaton, A.D., Clesceri, L.S., and Greenberg, A.E., eds.,1995, Standard methods for examination of water and wastewater, chapter 9: Washington, D.C., American Public Health Association, p. 117.

Feth, J.H., 1981, Chloride in natural continental water-a review: U.S. Geological Survey Water-Supply Paper 2176, $30 \mathrm{p}$.

Galloway, J.M., and Green, W.R., 2002, Simulation of hydrodynamics, temperature, and dissolved oxygen in Norfork Lake, Arkansas, 1994-1995: U.S. Geological Survey WaterResources Investigations Report 02-4250, 23 p.
Hem, J.D., 1992, Study and interpretation of the chemical characteristics of natural water (3d ed.): U.S. Geological Survey Water-Supply Paper 2254, 263 p.

Hendricks, C.W., 1972, Enteric bacterial growth rates in river water: Applied Microbiology, v. 24, no. 2, p. 168-174.

Horne, A.J., and Goldman, C.R., 1994, Limnology (2d ed.): New York, McGraw-Hill Inc., 576 p.

Kansas Department of Health and Environment, 2002, Kansas register, article 16, surface water quality standards: Topeka, Kansas, Secretary of State, v. 21, no. 51, p. 2096-2109.

Kansas Department of Health and Environment, 2004, 2004 Kansas water quality assessment (305(b) report): Topeka, Kansas Secretary of State, information available on Web, accessed April 2004, at http://www.kdhe.state.ks.us/ befs/download/ 305b04text12f.pdf, 48 p.

Kennedy, E.J., 1984, Discharge ratings at gaging stations: U.S. Geological Survey Techniques of Water-Resources Investigations, book 3, chap. A10, 59 p.

Lund, J.W.G., Kipling, C., and LeCren, E.D., 1958, The inverted microscope method of estimating algal numbers and the statistical basis of estimates by counting: Hydrobiologia, v. 11, p. 143-170.

Myers, D.N., and Sylvester, M.A., 1997, Fecal indicator bacteria, in Myers, D.N., and Wilde, F.D, eds., 1999, Biological indicators, in National field manual for the collection of water-quality data: U.S. Geological Survey Techniques of Water-Resources Investigations, book 9, chap. A7, p. 3-38.

National Oceanic and Atmospheric Administration, 2002, Climatological data annual summary, North Carolina, 2001: Ashville, North Carolina, National Climatic Data Center, v. 115 , no. 13,25 p.

National Oceanic and Atmospheric Administration, 2003, Climatological data annual summary, North Carolina, 2002: Ashville, North Carolina, National Climatic Data Center, v. 116 , no. 13,25 p.

Pepper, I.L., Gerba, C.P., and Brusseau, M.L., eds., 1996, Pollution science: New York, Academic Press, 397 p.

Policy Research Institute, 2002, 2000 census data in Kansas: Lawrence, The University of Kansas, information available on Web, accessed June 2004, at http://www.ku.edu/pri/ ksdata/ksah/KSA.pdf

Putnam, J.E., Lacock, D.L., and Schneider, D.R., 2002, Water resources data-Kansas, water year 2001: U.S. Geological Survey Water-Data Report KS-01-1, 532 p.

Rasmussen, P.P., and Ziegler, A. Z., 2003, Comparison and continuous estimates of fecal coliform and Escherichia coli bacteria in selected streams, May 1999 through April 2002: U.S. Geological Survey Water-Resources Investigations Report 03-4056, p. 7-8.

U.S. Environmental Protection Agency, 1986, Quality criteria for water, 1986: U.S. Environmental Protection Agency Report 440/5-86-001, unnumbered pages. 
U.S. Environmental Protection Agency, 1999, Update of ambient water quality criteria for ammonia: U.S. Environmental Protection Agency Report 822-R-99-014, 147 p.

U.S. Environmental Protection Agency, 2003, Ecoregional nutrient criteria: Information available on Web, accessed July 9, 2003, at http://www.epa.gov/waterscience/ criteria/nutrient/ecoregions/sumtable.pdf

Wagner, R.J., Mattraw, H.C., Ritz, G.F., and Smith, B.A., 2000, Guidelines and standard procedures for continuous waterquality monitors - site selection, field operations, calibration, record computation, and reporting: U.S. Geological Survey Water-Resources Investigations Report 00-4252, $53 \mathrm{p}$.
Wetzel, R.G., 2001, Limnology lake and river ecosystems (3d ed): San Diego, California, Academic Press, 1006 p.

Wilde, F.D., Radke, D.B., Gibs, Jacob, and Iwatsubo, R.T., eds., 1999, Collection of water samples, in National field manual for the collection of water-quality data: U.S. Geological Survey Techniques of Water-Resources Investigations, book 9, chap A4, p. 7-48.

Wolf, R.J., and Helgesen, J.O., 1992, Ground- and surfacewater interaction between the Kansas River and the associated alluvial aquifer, northeastern Kansas: U.S. Geological Survey Water-Resources Investigations Report 92-4137, $49 \mathrm{p}$. 
Appendixes 
Appendix 1. Water-quality results from samples collected from Kansas River, northeast Kansas, selected tributaries, and selected wastewater-treatment facility effluent for synoptic surveys I, II, and III, November 2001 through August 2002.

$\left[<\right.$, less than; --, not determined; E, estimated; >, greater than; $\mathrm{FNU}$, formazin nephelometric units; $\mathrm{CO}_{3}$, carbonate; $\mathrm{HCO}_{3}$, bicarbonate; $\mathrm{CaCO}_{3}$, calcium carbonate; ${ }^{\circ} \mathrm{C}$, degrees Celsius; $\mathrm{SO}_{4}$, sulfate; $\mathrm{Cl}_{\text {, }}$ chloride, N, nitrogen; P, phosphorus; C, carbon]

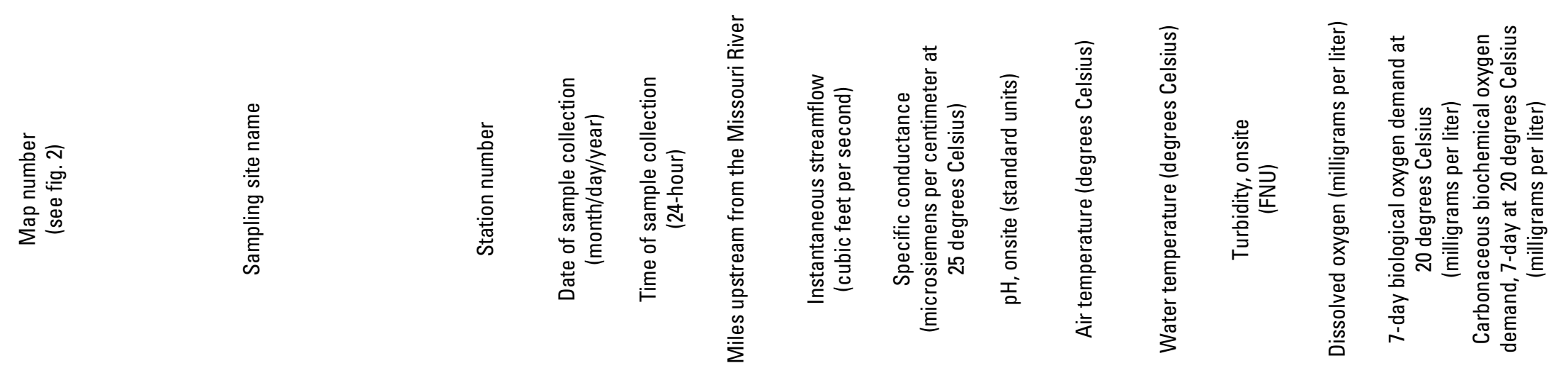

\begin{tabular}{|c|c|c|c|c|c|c|c|c|c|c|c|c|c|c|}
\hline \multicolumn{15}{|c|}{ Synoptic survey I } \\
\hline 10 & Kansas River at Highway 75, Topeka & 6888980 & $11 / 29 / 01$ & 1100 & 86.0 & 1,500 & 990 & 8.2 & 2.0 & 2.6 & 150 & 13.3 & 2.8 & $<1.0$ \\
\hline 11 & $\begin{array}{l}\text { North Topeka wastewater-treatment } \\
\text { facility }\end{array}$ & 6888985 & $11 / 28 / 01$ & 1220 & 85.0 & .12 & 1,200 & 7.3 & -2.0 & 17.4 & 640 & 6.9 & 21 & 14 \\
\hline 13 & $\begin{array}{l}\text { Topeka Oakland wastewater-treatment } \\
\text { facility }\end{array}$ & 6889002 & $11 / 28 / 01$ & 1115 & 81.7 & 16 & 1,200 & 7.7 & -- & 18.6 & 9.6 & 8.2 & 19 & 11 \\
\hline 15 & $\begin{array}{l}\text { Soldier Creek, Meriden Road, near } \\
\text { Topeka }\end{array}$ & 6889504 & $11 / 29 / 01$ & 930 & 80.5 & -- & 760 & 7.8 & -- & -- & 6.3 & 11.8 & 2.4 & $<1.0$ \\
\hline 16 & $\begin{array}{l}\text { Shunganunga Creek at Rice Road, } \\
\text { Topeka }\end{array}$ & 6889700 & $11 / 29 / 01$ & 1030 & 76.0 & 6.6 & 580 & 8.1 & 3.0 & 3.5 & 17 & 11.8 & 2.0 & $<1.0$ \\
\hline 18 & Muddy Creek near Grantville & 6889800 & $11 / 28 / 01$ & 850 & 72.3 & 5.9 & 640 & 7.9 & 0 & 2.7 & 3.4 & 11.3 & 3.3 & 1.4 \\
\hline 20 & Delaware River below Perry Dam & 6890900 & $11 / 28 / 01$ & 920 & 65.1 & 25 & 270 & 8.1 & -1.5 & 9.6 & 94 & 10.8 & 3.9 & $<1.0$ \\
\hline 21 & Kansas River at Lecompton & 6891000 & $11 / 28 / 01$ & 1330 & 64.0 & 1,800 & 980 & 8.3 & -2.0 & 3.8 & 20 & 12.8 & 4.8 & 2.1 \\
\hline 25 & Lawrence wastewater-treatment facility & 6891090 & $11 / 28 / 01$ & 920 & 51.1 & 9.9 & 900 & 7.4 & -- & 16.3 & 49 & 8.4 & 18 & 7.1 \\
\hline 27 & $\begin{array}{l}\text { Farmland nitrogen wastewater- } \\
\text { treatment facility, Lawrence }\end{array}$ & 6891095 & $11 / 28 / 01$ & 845 & 50.1 & .26 & 1,700 & 7.6 & -- & 2.3 & 60 & 11.0 & 12 & 8.6 \\
\hline 29 & Mud Creek near Lawrence & 6891098 & $11 / 27 / 01$ & 1145 & 47.6 & 2.0 & 610 & 7.7 & 4.5 & 6.5 & 17 & 10.8 & 2.9 & $<1.0$ \\
\hline 30 & Kansas River at Eudora & 6891100 & $11 / 28 / 01$ & 1030 & 43.4 & 1,820 & 820 & 8.3 & 0 & 4.7 & 19 & 12.4 & 4.9 & 2.3 \\
\hline
\end{tabular}


Appendix 1. Water-quality results from samples collected from Kansas River, northeast Kansas, selected tributaries, and selected wastewater-treatment facility effluent for synoptic surveys I, II, and III, November 2001 through August 2002.-Continued

$\left[<\right.$, less than; --, not determined; E, estimated; >, greater than; $\mathrm{FNU}$, formazin nephelometric units; $\mathrm{CO}_{3}$, carbonate; $\mathrm{HCO}_{3}$, bicarbonate; $\mathrm{CaCO}_{3}$, calcium carbonate; ${ }^{\circ} \mathrm{C}$, degrees $\mathrm{Celsius} ; \mathrm{SO}_{4}$, sulfate; $\mathrm{Cl}_{\text {, }}$ chloride, $\mathrm{N}$, nitrogen; P, phosphorus; $\mathrm{C}$, carbon]

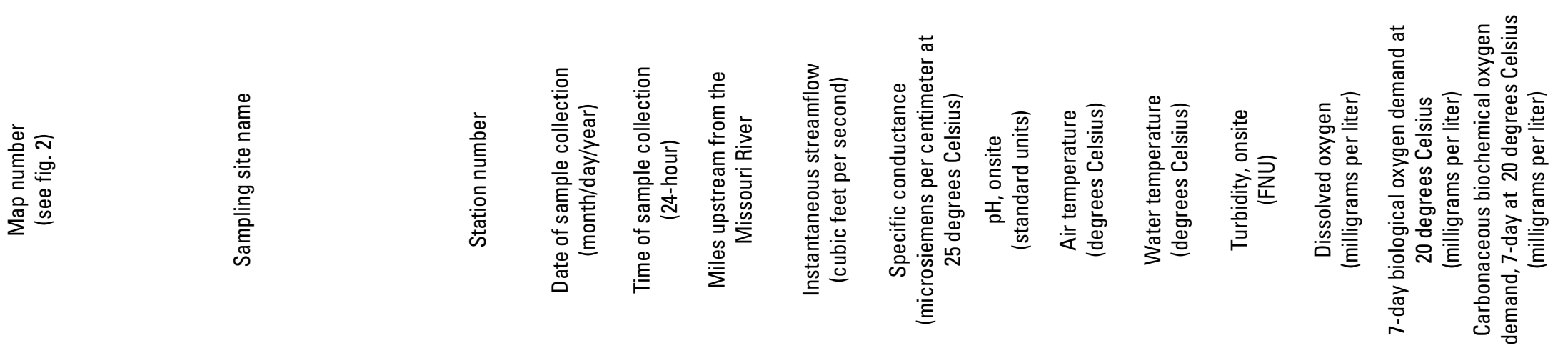

\section{Synoptic survey L-Continued}

\begin{tabular}{|c|c|c|c|c|c|c|c|c|c|c|c|c|c|c|}
\hline 31 & $\begin{array}{l}\text { Wakarusa River at } 1900 \text { Road near } \\
\text { Eudora }\end{array}$ & 6891675 & $11 / 27 / 01$ & 755 & 42.6 & E7.0 & 500 & 7.3 & -- & 7.3 & 26 & 9.4 & 4.3 & 1.3 \\
\hline 32 & Stranger Creek above Linwood & 6892200 & $11 / 27 / 01$ & 1240 & 35.4 & 53 & 570 & 8.1 & 10.5 & 7.8 & 17 & 11.5 & 3.2 & $<1.0$ \\
\hline 35 & Kill Creek at 83rd Street & 6892360 & $11 / 27 / 01$ & 1015 & 31.0 & 1.2 & 650 & 8.0 & 1.0 & 6.9 & 8.5 & 10.2 & 3.5 & 1.1 \\
\hline 37 & Cedar Creek near Cedar Junction & 6892490 & $11 / 27 / 01$ & 830 & 26.7 & 4.7 & 990 & 8.0 & 1.0 & 7.2 & 22 & 10.0 & 3.2 & $<1.0$ \\
\hline 39 & $\begin{array}{l}\text { Bonner Springs wastewater-treatment } \\
\text { facility }\end{array}$ & 6892502 & $11 / 29 / 01$ & 1010 & 20.3 & 1.1 & 1,300 & 7.4 & -- & 16.0 & 4.6 & 5.2 & 5.5 & $<1.0$ \\
\hline 42 & Mill Creek at Wilder Road & 6892515 & $11 / 27 / 01$ & 845 & 16.1 & 15 & 640 & 7.6 & 2.0 & 7.2 & 60 & 9.9 & 3.8 & 1.5 \\
\hline 44 & $\begin{array}{l}\text { Johnson County Mill Creek wastewater- } \\
\text { treatment facility }\end{array}$ & 6892520 & $11 / 27 / 01$ & 1215 & 15.0 & E11 & 1,100 & 7.4 & 2.0 & 11.2 & 670 & 9.0 & 47 & 6.9 \\
\hline 45 & $\begin{array}{l}\text { Kansas City wastewater-treatment } \\
\text { facility no. } 20\end{array}$ & 6892525 & $11 / 27 / 01$ & 930 & 14.8 & 5.2 & 1,200 & 7.2 & -- & 17.9 & 2.8 & 4.3 & 16 & 3.0 \\
\hline 46 & $\begin{array}{l}\text { Unnamed tributary below Kansas City } \\
\text { wastewater-treatment facility no. } 14\end{array}$ & 6892527 & $11 / 27 / 01$ & 1100 & 11.2 & -- & 570 & 8.0 & -- & 5.7 & 690 & 11.6 & 10 & 3.2 \\
\hline 48 & $\begin{array}{l}\text { Kansas River at west Kansas Avenue } \\
\text { Bridge }\end{array}$ & 6892540 & $11 / 28 / 01$ & 1010 & 6.0 & $\mathrm{E} 2,600$ & 750 & 8.3 & -1.0 & 6.4 & 22 & 12.0 & 6.0 & 3.0 \\
\hline 49 & Turkey Creek at Kansas City near I-35 & 6892942 & $11 / 27 / 01$ & 1030 & 3.2 & 20 & 980 & 7.6 & 3.5 & 13.8 & 17 & 7.5 & 31 & 22 \\
\hline 50 & Kansas River above Missouri River & 6892960 & $11 / 27 / 01$ & 1230 & 1.1 & 2,620 & 770 & 8.2 & 4.0 & 9.3 & 59 & 11.0 & 5.9 & 3.0 \\
\hline
\end{tabular}

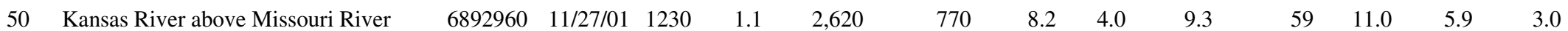


Appendix 1. Water-quality results from samples collected from Kansas River, northeast Kansas, selected tributaries, and selected wastewater-treatment facility effluent for synoptic surveys I, II, and III, November 2001 through August 2002.-Continued

$\left[<\right.$, less than; --, not determined; E, estimated; $>$, greater than; $\mathrm{FNU}$, formazin nephelometric units; $\mathrm{CO}_{3}$, carbonate; $\mathrm{HCO}_{3}$, bicarbonate; $\mathrm{CaCO}_{3}$, calcium carbonate; ${ }^{\circ} \mathrm{C}$, degrees Celsius; $\mathrm{SO}_{4}$, sulfate; $\mathrm{Cl}$, chloride, N, nitrogen; P, phosphorus; C, carbon]

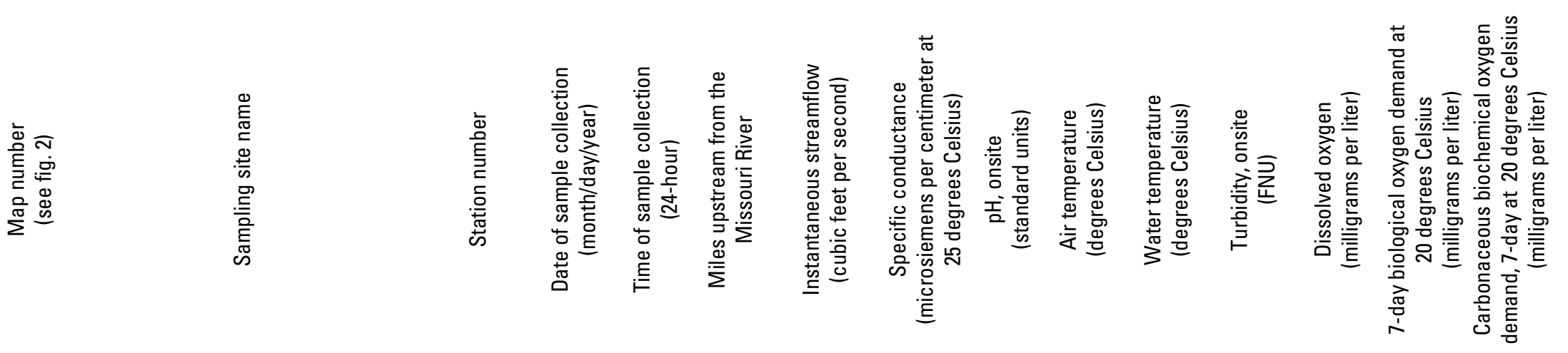

\begin{tabular}{|c|c|c|c|c|c|c|c|c|c|c|c|c|c|c|}
\hline \multicolumn{15}{|c|}{ Synoptic survey II } \\
\hline 2 & Vermillion Creek near Wamego & 6888000 & $2 / 28 / 02$ & 1310 & 119.2 & 18 & 640 & 8.2 & 7.0 & 3.6 & 10 & 14.6 & 2.7 & $<1.0$ \\
\hline 3 & Rock Creek near Louisville & 6888300 & $2 / 28 / 02$ & 1215 & 118.2 & 10 & 570 & 8.3 & 7.5 & 1.6 & 11 & 14.4 & 2.2 & $<1.0$ \\
\hline 4 & Kansas River at Belvue & 6888350 & $2 / 28 / 02$ & 1315 & 113.0 & 2,150 & 1,000 & 8.1 & 11.2 & 2.5 & 32 & 12.5 & 3.6 & 2.0 \\
\hline 5 & Kansas River near Maple Hill & 6888400 & $2 / 28 / 02$ & 1135 & 103.7 & 1,700 & 1,100 & 8.3 & 11.0 & 1.8 & 41 & 15.9 & 3.7 & 3.2 \\
\hline 6 & Mill Creek near Maple Hill & 6888650 & $2 / 28 / 02$ & 1015 & 101.7 & 27 & 680 & 8.1 & 4.0 & 3.2 & 15 & 12.8 & 2.9 & 1.3 \\
\hline 7 & Cross Creek near Rossville & 6888700 & $2 / 28 / 02$ & 1400 & 100.1 & 9.1 & 730 & 8.0 & 6.5 & 2.7 & 8.5 & 13.0 & 1.8 & $<1.0$ \\
\hline 8 & Kansas River at Willard & 6888705 & $2 / 28 / 02$ & 950 & 98.9 & -- & 1,100 & 8.2 & 6.0 & .1 & 34 & 15.8 & 3.7 & 3.4 \\
\hline 9 & Mission Creek near Valencia & 6888800 & $2 / 28 / 02$ & 900 & 91.6 & 10 & 610 & 8.1 & 0 & 1.4 & 9.8 & 14.2 & 3.0 & 1.0 \\
\hline 10 & Kansas River at Highway 75, Topeka & 6888980 & $2 / 28 / 02$ & 1115 & 86.0 & 1,830 & 1,000 & 8.1 & 2.6 & .4 & 37 & 12.6 & 4.2 & 3.1 \\
\hline 11 & $\begin{array}{l}\text { North Topeka wastewater-treatment } \\
\text { facility }\end{array}$ & 6888985 & $2 / 26 / 02$ & 1130 & 85.0 & 13 & 1,200 & 7.0 & -7.0 & 14.2 & 310 & 8.3 & 14 & 7.0 \\
\hline 12 & Kansas River at Topeka & 6889000 & $2 / 27 / 02$ & 1320 & 83.0 & 1,800 & 1,000 & 8.2 & -- & .4 & 30 & 16.9 & 7.4 & 3.9 \\
\hline 13 & $\begin{array}{l}\text { Topeka Oakland wastewater-treatment } \\
\text { facility }\end{array}$ & 6889002 & $2 / 26 / 02$ & 1045 & 81.7 & 16 & 1,400 & 7.5 & -7.0 & 14.2 & 11 & 10.9 & 16 & 12 \\
\hline 14 & Kansas River at Highway 4, Topeka & 6889010 & $2 / 28 / 02$ & 855 & 81.1 & 1,820 & 1,000 & 8.0 & -1.3 & .1 & 34 & 13.2 & 5.8 & 3.6 \\
\hline 15 & $\begin{array}{l}\text { Soldier Creek, Meriden Road, near } \\
\text { Topeka }\end{array}$ & 6889504 & $2 / 27 / 02$ & 1215 & 80.5 & 48 & 780 & 8.0 & -1.5 & .9 & 12 & 14.7 & 2.9 & 2.1 \\
\hline
\end{tabular}


Appendix 1. Water-quality results from samples collected from Kansas River, northeast Kansas, selected tributaries, and selected wastewater-treatment facility effluent for synoptic surveys I, II, and III, November 2001 through August 2002.-Continued

$\left[<\right.$, less than; --, not determined; E, estimated; $>$, greater than; $\mathrm{FNU}$, formazin nephelometric units; $\mathrm{CO}_{3}$, carbonate; $\mathrm{HCO}_{3}$, bicarbonate; $\mathrm{CaCO}_{3}$, calcium carbonate; ${ }^{\circ} \mathrm{C}$, degrees Celsius; $\mathrm{SO}_{4}$, sulfate; $\mathrm{Cl}$, chloride, N, nitrogen; P, phosphorus; C, carbon]

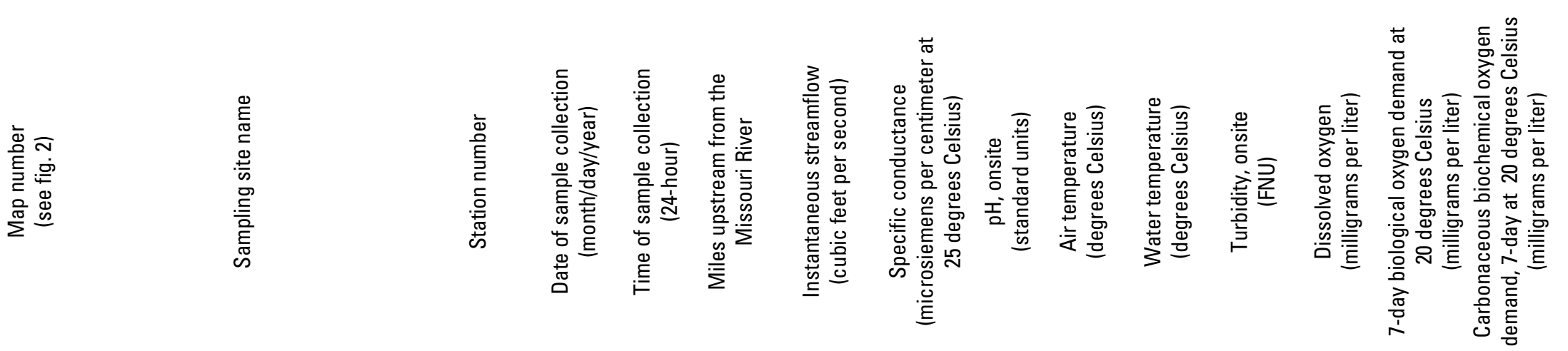

\begin{tabular}{|c|c|c|c|c|c|c|c|c|c|c|c|c|c|c|}
\hline \multicolumn{15}{|c|}{ Synoptic survey II-Continued } \\
\hline 16 & $\begin{array}{l}\text { Shunganunga Creek at Rice Road, } \\
\text { Topeka }\end{array}$ & 6889700 & $2 / 27 / 02$ & 1315 & 76.0 & 8.5 & 790 & 8.2 & -1.5 & 2.2 & 25 & 14.1 & 2.8 & 1.6 \\
\hline 17 & Kansas River near Grantville & 6889750 & $2 / 28 / 02$ & 1100 & 73.7 & -- & 1,100 & 8.2 & 12.0 & .7 & -- & 12.2 & 5.6 & 3.8 \\
\hline 18 & Muddy Creek near Grantville & 6889800 & $2 / 27 / 02$ & 900 & 72.3 & 3.9 & 680 & 8.0 & E-8.0 & .2 & 7.0 & 14.1 & 2.0 & $<1.0$ \\
\hline 19 & Kansas River near Grover & 6889850 & $2 / 28 / 02$ & 1330 & 68.6 & -- & 1,100 & 8.4 & -- & 2.2 & -- & 12.5 & 5.7 & 3.9 \\
\hline 20 & Delaware River below Perry Dam & 6890900 & $2 / 27 / 02$ & 930 & 65.1 & 100 & 290 & 8.5 & -5.0 & 3.4 & 86 & 14.2 & 2.9 & 1.8 \\
\hline 21 & Kansas River at Lecompton & 6891000 & $2 / 27 / 02$ & 1025 & 64.0 & 1,900 & 1,000 & 8.5 & -5.0 & 1.7 & 36 & 16.5 & 5.7 & 4.3 \\
\hline 22 & Buck Creek at Williamstown & 6891060 & $2 / 27 / 02$ & 1015 & 58.6 & .69 & 500 & 7.9 & -1.0 & .9 & 3.5 & 14.5 & 2.1 & 1.2 \\
\hline 23 & Kansas River near Midland & 6891070 & $3 / 1 / 02$ & 935 & 57.5 & -- & 980 & 8.1 & 2.2 & 1.6 & 34 & 13.9 & 6.1 & 6.0 \\
\hline 24 & Kansas River at Lawrence & 6891080 & $2 / 27 / 02$ & 1020 & 51.9 & -- & 990 & 8.4 & -1.9 & .3 & 31 & 13.5 & 7.3 & 5.8 \\
\hline 25 & Lawrence wastewater-treatment facility & 6891090 & $2 / 25 / 02$ & 1305 & 51.1 & 11 & 1,100 & 7.2 & 4.5 & 13.8 & -- & 11.2 & 18 & 9.8 \\
\hline 26 & $\begin{array}{l}\text { Kansas River between Lawrence and } \\
\text { Farmland facility }\end{array}$ & 6891093 & $2 / 27 / 02$ & 1115 & 50.6 & -- & 1,000 & 8.5 & -3.0 & .5 & 2.8 & 11.2 & 7.0 & 5.1 \\
\hline 27 & $\begin{array}{l}\text { Farmland nitrogen wastewater- } \\
\text { treatment facility, Lawrence }\end{array}$ & 6891095 & $2 / 26 / 02$ & 840 & 50.1 & .62 & 2,000 & 7.3 & -11.0 & .2 & 39 & 16.7 & 41 & 36 \\
\hline 28 & Kansas River below Farmland facility & 6891096 & $2 / 27 / 02$ & 1300 & 48.6 & -- & 1,000 & 8.7 & -5.0 & 2.0 & 2.6 & 13.5 & 8.2 & 6.3 \\
\hline
\end{tabular}


Appendix 1. Water-quality results from samples collected from Kansas River, northeast Kansas, selected tributaries, and selected wastewater-treatment facility effluent for synoptic surveys I, II, and III, November 2001 through August 2002.-Continued

$\left[<\right.$, less than; --, not determined; E, estimated; $>$, greater than; $\mathrm{FNU}$, formazin nephelometric units; $\mathrm{CO}_{3}$, carbonate; $\mathrm{HCO}_{3}$, bicarbonate; $\mathrm{CaCO}_{3}$, calcium carbonate; ${ }^{\circ} \mathrm{C}$, degrees Celsius; $\mathrm{SO}_{4}$, sulfate; $\mathrm{Cl}$, chloride, N, nitrogen; P, phosphorus; C, carbon]

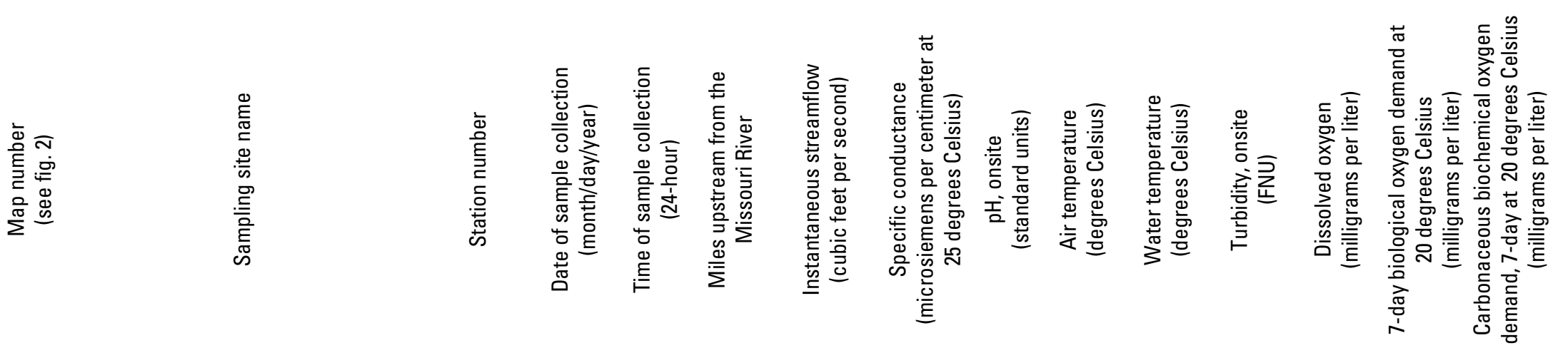

\begin{tabular}{|c|c|c|c|c|c|c|c|c|c|c|c|c|c|c|}
\hline \multicolumn{15}{|c|}{ Synoptic survey II-Continued } \\
\hline 29 & Mud Creek near Lawrence & 6891098 & $2 / 26 / 02$ & 1045 & 47.6 & E3.0 & 520 & 7.8 & -4.0 & 3.3 & 33 & 12.0 & 2.5 & 1.7 \\
\hline 30 & Kansas River at Eudora & 6891100 & $2 / 25 / 02$ & 930 & 43.4 & 2,260 & 980 & 8.8 & 1.0 & 7.4 & 41 & 12.7 & 9.5 & 8.3 \\
\hline 31 & $\begin{array}{l}\text { Wakarusa River at } 1900 \text { Road near } \\
\text { Eudora }\end{array}$ & 6891675 & $2 / 26 / 02$ & 900 & 42.6 & 8.9 & 490 & 8.2 & E-8.0 & 2.7 & 25 & 12.8 & 2.3 & 1.5 \\
\hline 32 & Stranger Creek above Linwood & 6892200 & $2 / 26 / 02$ & 1145 & 35.4 & 40 & 550 & 8.1 & -4.0 & 4.6 & 19 & 11.9 & 2.2 & 1.5 \\
\hline 33 & Kansas River at DeSoto & 6892350 & $2 / 25 / 02$ & 1230 & 31.7 & 1,740 & 910 & 8.8 & 3.0 & 6.6 & 52 & 10.1 & 9.2 & 7.7 \\
\hline 34 & DeSoto wastewater-treatment facility & 6892358 & $2 / 25 / 02$ & 830 & 31.0 & 1.0 & 870 & 7.2 & 1.0 & 12.6 & .8 & 2.6 & 8.2 & 3.4 \\
\hline 35 & Kill Creek at 83rd Street & 6892360 & $2 / 25 / 02$ & 915 & 31.0 & 8.6 & 550 & 7.9 & 1.0 & 6.9 & 39 & 11.1 & 2.6 & 1.6 \\
\hline 36 & Kansas River near Cedar & 6892380 & $2 / 26 / 02$ & 1230 & 30.8 & -- & 980 & 8.8 & -7.0 & 1.2 & -- & -- & 8.4 & 6.7 \\
\hline 37 & Cedar Creek near Cedar Junction & 6892490 & $2 / 25 / 02$ & 1315 & 26.7 & 18.2 & 770 & 8.4 & 5.0 & 8.0 & 27 & 13.4 & 1.9 & 1.4 \\
\hline 38 & Kansas River at Bonner Springs & 6892500 & $2 / 26 / 02$ & 1030 & 20.7 & -- & 970 & 8.7 & -5.0 & 1.9 & 55 & 12.8 & 9.9 & 7.8 \\
\hline 39 & $\begin{array}{l}\text { Bonner Springs wastewater-treatment } \\
\text { facility }\end{array}$ & 6892502 & $2 / 26 / 02$ & 945 & 20.3 & 1.0 & 1,300 & 7.6 & -8.0 & 11.7 & .4 & 6.4 & 2.1 & 1.8 \\
\hline 40 & Kansas River near Lake of the Forest & 6892504 & $2 / 26 / 02$ & 1005 & 19.4 & -- & 970 & 9.0 & -8.0 & 2.3 & 85 & 13.6 & 10 & 8.1 \\
\hline 41 & Kansas River near Edwardsville & 6892505 & $2 / 26 / 02$ & 1130 & 16.6 & -- & 920 & 8.6 & -2.1 & 2.4 & 65 & 17.8 & 11 & 8.3 \\
\hline 42 & Mill Creek at Wilder Road & 6892515 & $2 / 25 / 02$ & 1015 & 16.1 & 20 & 930 & 8.2 & 4.5 & 7.3 & 27 & 12.7 & 2.0 & 1.1 \\
\hline
\end{tabular}


Appendix 1. Water-quality results from samples collected from Kansas River, northeast Kansas, selected tributaries, and selected wastewater-treatment facility effluent for synoptic surveys I, II, and III, November 2001 through August 2002.-Continued

$\left[<\right.$, less than; --, not determined; E, estimated; $>$, greater than; $\mathrm{FNU}$, formazin nephelometric units; $\mathrm{CO}_{3}$, carbonate; $\mathrm{HCO}_{3}$, bicarbonate; $\mathrm{CaCO}_{3}$, calcium carbonate; ${ }^{\circ} \mathrm{C}$, degrees Celsius; $\mathrm{SO}_{4}$, sulfate; $\mathrm{Cl}$, chloride, N, nitrogen; P, phosphorus; C, carbon]

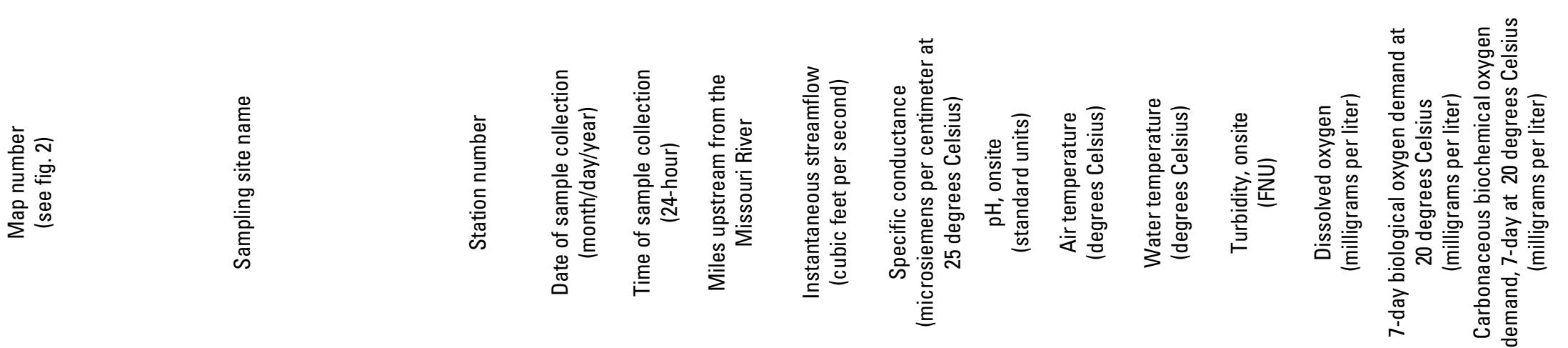

\begin{tabular}{|c|c|c|c|c|c|c|c|c|c|c|c|c|c|c|}
\hline \multicolumn{15}{|c|}{ Synoptic survey II-Continued } \\
\hline 43 & Kansas River near I-435 Bridge & 6892518 & $2 / 26 / 02$ & 925 & 15.4 & -- & 910 & 8.5 & -3.4 & 3.1 & 50 & 13.2 & 9.2 & 7.9 \\
\hline 44 & $\begin{array}{l}\text { Johnson County Mill Creek wastewater- } \\
\text { treatment facility }\end{array}$ & 6892520 & $2 / 25 / 02$ & 1150 & 15.0 & 12 & 1,200 & 7.2 & 4.5 & 10.5 & 24 & 7.7 & 48 & 17 \\
\hline 45 & $\begin{array}{l}\text { Kansas City wastewater-treatment } \\
\text { facility no. } 20\end{array}$ & 6892525 & $2 / 25 / 02$ & 1000 & 14.8 & 5.4 & 1,200 & 6.9 & 4.5 & 13.2 & .9 & 4.7 & 8.2 & 1.9 \\
\hline 46 & $\begin{array}{l}\text { Unnamed tributary below Kansas City } \\
\text { wastewater-treatment facility no. } 14\end{array}$ & 6892527 & $2 / 25 / 02$ & 1030 & 11.2 & 1.0 & 790 & 7.9 & 4.5 & 5.6 & 9.5 & 14.6 & 1.4 & $<1.0$ \\
\hline 47 & Kansas River at Turner Bridge & 6892530 & $2 / 25 / 02$ & 1235 & 9.7 & -- & 870 & 8.6 & 4.8 & 9.2 & 62 & 13.9 & 11 & 9.1 \\
\hline 48 & $\begin{array}{l}\text { Kansas River at west Kansas Avenue } \\
\text { Bridge }\end{array}$ & 6892540 & $2 / 25 / 02$ & 1050 & 6.0 & 2,220 & 850 & 8.5 & 1.9 & 9.0 & 65 & 13.0 & 12 & 11 \\
\hline 49 & Turkey Creek at Kansas City near I-35 & 6892942 & $2 / 25 / 02$ & 1120 & 3.2 & 26.3 & 1,000 & 7.8 & 4.5 & 11.6 & 13 & 9.1 & 24 & 21 \\
\hline 50 & $\begin{array}{l}\text { Kansas River above Missouri River } \\
\text { confluence }\end{array}$ & 6892960 & $2 / 25 / 02$ & 745 & 1.1 & 2,190 & 840 & 8.4 & 0 & 8.7 & 70 & 12.1 & 9.0 & 7.1 \\
\hline \multicolumn{15}{|c|}{ Synoptic survey III } \\
\hline 1 & Kansas River at Wamego & 6887500 & $7 / 31 / 02$ & 1005 & 124.0 & 1,446 & 1,400 & 8.7 & -- & 28.0 & 65 & 8.9 & 10.9 & 7.52 \\
\hline 2 & Vermillion Creek near Wamego & 6888000 & $8 / 1 / 02$ & 1020 & 119.2 & 1.0 & 510 & 7.9 & 31.5 & 29.1 & 38 & 6.3 & 6.5 & 4.14 \\
\hline 3 & Rock Creek near Louisville & 6888300 & $8 / 1 / 02$ & 945 & 118.2 & 1.7 & 420 & 8.3 & 35.0 & 28.8 & 55 & 6.2 & 2.5 & 1.11 \\
\hline 4 & Kansas River at Belvue & 6888350 & $7 / 31 / 02$ & 1205 & 113.0 & 942 & 900 & 8.6 & -- & 29.2 & 67 & 10.0 & 14.9 & 11.7 \\
\hline
\end{tabular}


Appendix 1. Water-quality results from samples collected from Kansas River, northeast Kansas, selected tributaries, and selected wastewater-treatment facility effluent for synoptic surveys I, II, and III, November 2001 through August 2002.-Continued

$\left[<\right.$, less than; --, not determined; E, estimated; $>$, greater than; $\mathrm{FNU}$, formazin nephelometric units; $\mathrm{CO}_{3}$, carbonate; $\mathrm{HCO}_{3}$, bicarbonate; $\mathrm{CaCO}_{3}$, calcium carbonate; ${ }^{\circ} \mathrm{C}$, degrees Celsius; $\mathrm{SO}_{4}$, sulfate; $\mathrm{Cl}$, chloride, N, nitrogen; P, phosphorus; C, carbon]

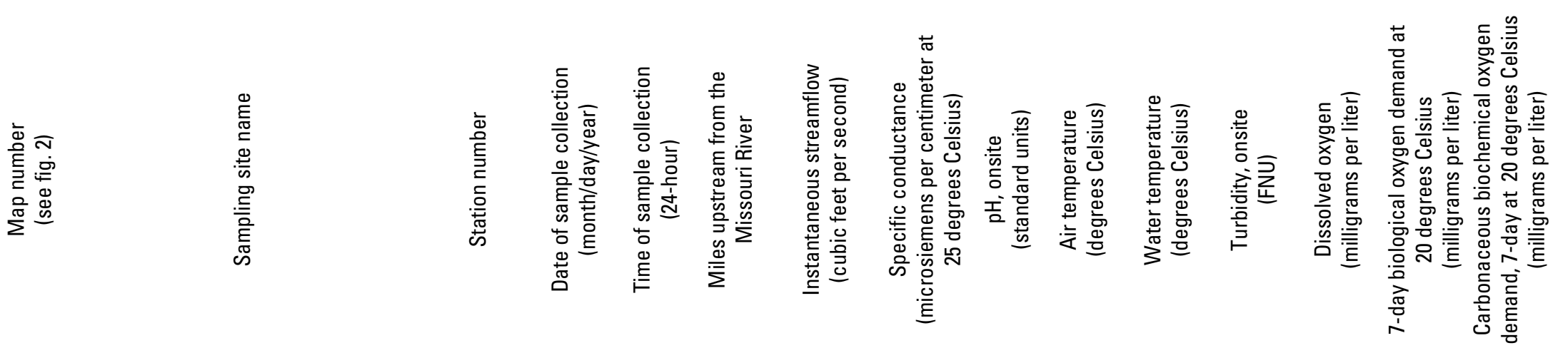

\begin{tabular}{|c|c|c|c|c|c|c|c|c|c|c|c|c|c|c|}
\hline \multicolumn{15}{|c|}{ Synoptic survey III-Continued } \\
\hline 5 & Kansas River near Maple Hill & 6888400 & $7 / 31 / 02$ & 750 & 103.7 & -- & 970 & 8.5 & 29.0 & 27.2 & 64 & 6.9 & 9.0 & 7.6 \\
\hline 6 & Mill Creek near Maple Hill & 6888650 & $8 / 1 / 02$ & 1130 & 101.7 & 12 & 610 & 8.1 & 34.5 & 30.2 & 12 & 8.7 & 3.2 & 2.3 \\
\hline 7 & Cross Creek near Rossville & 6888700 & $7 / 31 / 02$ & 1155 & 100.1 & 3.0 & 630 & 7.7 & 31.0 & 28.2 & 52 & 5.1 & 1.7 & 1.4 \\
\hline 8 & Kansas River at Willard & 6888705 & $7 / 31 / 02$ & 1020 & 98.9 & -- & 930 & 8.5 & 36.0 & 28.1 & 60 & 8.1 & 8.2 & 6.7 \\
\hline 9 & Mission Creek near Valencia & 6888800 & $8 / 1 / 02$ & 1210 & 91.6 & .42 & 610 & 7.4 & 39.5 & 29.3 & 13 & 7.2 & 2.3 & 1.4 \\
\hline 10 & Kansas River at Highway 75, Topeka & 6888980 & $7 / 31 / 02$ & 1220 & 86.0 & -- & 760 & 8.6 & -- & 29.9 & 62 & 11.1 & 10.6 & 9.1 \\
\hline 11 & $\begin{array}{l}\text { North Topeka wastewater-treatment } \\
\text { facility }\end{array}$ & 6888985 & $7 / 30 / 02$ & 845 & 85.0 & 5 & 1,200 & 7.0 & 33.5 & 25.5 & 120 & 5.7 & 2.6 & 2.5 \\
\hline \multirow[t]{5}{*}{12} & Kansas River at Topeka & 6889000 & $7 / 23 / 02$ & 1005 & 83.0 & 1,090 & 790 & 8.0 & 33.0 & 26.2 & 48 & 7.4 & -- & -- \\
\hline & & & $8 / 2 / 02$ & 855 & 83.0 & 824 & 1,200 & 8.2 & -- & 27.3 & 63 & 5.7 & -- & -- \\
\hline & & & $8 / 2 / 02$ & 1500 & 83.0 & 798 & 1,100 & 8.5 & -- & 30.1 & -- & 9.2 & -- & -- \\
\hline & & & $8 / 5 / 02$ & 1515 & 83.0 & -- & 1,000 & 8.2 & 40.0 & 31.0 & 84 & 8.9 & -- & -- \\
\hline & & & $8 / 6 / 02$ & 900 & 83.0 & -- & 1,000 & 7.9 & 29.0 & 29.1 & 52 & 5.6 & -- & -- \\
\hline 13 & $\begin{array}{l}\text { Topeka Oakland wastewater-treatment } \\
\text { facility }\end{array}$ & 6889002 & $7 / 30 / 02$ & 815 & 81.7 & -- & 1,300 & 7.6 & 26.5 & 25.5 & 41 & 6.9 & 17.2 & 12.4 \\
\hline \multirow[t]{2}{*}{14} & Kansas River at Highway 4, Topeka & 6889010 & $7 / 31 / 02$ & 1340 & 81.1 & -- & 730 & 8.6 & -- & 31.7 & 57 & 13.0 & -- & -- \\
\hline & & & $8 / 1 / 02$ & 735 & 81.1 & -- & 890 & 8.3 & 28.0 & 28.8 & 54 & 5.2 & 7.6 & 5.3 \\
\hline
\end{tabular}


Appendix 1. Water-quality results from samples collected from Kansas River, northeast Kansas, selected tributaries, and selected wastewater-treatment facility effluent for synoptic surveys I, II, and III, November 2001 through August 2002.-Continued

$\left[<\right.$, less than; --, not determined; E, estimated; $>$, greater than; $\mathrm{FNU}$, formazin nephelometric units; $\mathrm{CO}_{3}$, carbonate; $\mathrm{HCO}_{3}$, bicarbonate; $\mathrm{CaCO}_{3}$, calcium carbonate; ${ }^{\circ} \mathrm{C}$, degrees Celsius; $\mathrm{SO}_{4}$, sulfate; $\mathrm{Cl}$, chloride, N, nitrogen; P, phosphorus; C, carbon]

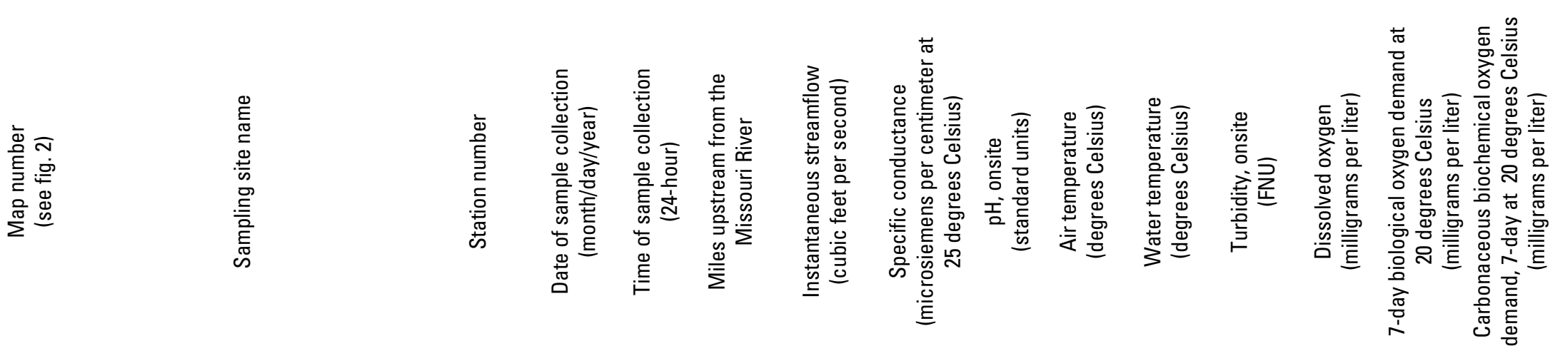

\begin{tabular}{|c|c|c|c|c|c|c|c|c|c|c|c|c|c|c|}
\hline \multicolumn{15}{|c|}{ Synoptic survey III-Continued } \\
\hline 15 & $\begin{array}{l}\text { Soldier Creek, Meriden Road, near } \\
\text { Topeka }\end{array}$ & 6889504 & $7 / 31 / 02$ & 1300 & 80.5 & 13.8 & 570 & 8.2 & 38.5 & 34.2 & 11 & 12.1 & 3.6 & 2.8 \\
\hline 16 & $\begin{array}{l}\text { Shunganunga Creek at Rice Road, } \\
\text { Topeka }\end{array}$ & 6889700 & $7 / 31 / 02$ & 1040 & 76.0 & 3.05 & 470 & 8.5 & 29.5 & 30.5 & 38 & 8.9 & 5.8 & 5.1 \\
\hline 17 & Kansas River near Grantville & 6889750 & $7 / 31 / 02$ & 1100 & 73.7 & -- & 710 & 8.3 & -- & 30.3 & 41 & 7.8 & 5.6 & 4.2 \\
\hline 18 & Muddy Creek near Grantville & 6889800 & $7 / 31 / 02$ & 1000 & 72.3 & .5 & 490 & 7.8 & 26.0 & 26.8 & 18 & 5.1 & 1.9 & 1.4 \\
\hline \multirow[t]{2}{*}{19} & Kansas River near Grover & 6889850 & $7 / 31 / 02$ & 900 & 68.6 & -- & 710 & 8.3 & -- & 28.3 & 38 & 7.1 & 5.1 & 4.2 \\
\hline & & & $7 / 31 / 02$ & 1400 & 68.6 & -- & 710 & 8.7 & -- & 31.4 & 38 & 10.7 & -- & -- \\
\hline 20 & Delaware River below Perry Dam & 6890900 & $7 / 30 / 02$ & 1210 & 65.1 & 25 & 340 & 7.8 & -- & 23.7 & 74 & 8.3 & 3.8 & 3.5 \\
\hline \multirow[t]{5}{*}{21} & Kansas River at Lecompton & 6891000 & $7 / 22 / 02$ & 1345 & 64.0 & 827 & 776 & 8.5 & 38.0 & 28.4 & -- & 11.7 & -- & -- \\
\hline & & & $8 / 1 / 02$ & 950 & 64.0 & 827 & 750 & 8.4 & -- & 28.7 & 45 & 9.3 & 11.6 & 8.4 \\
\hline & & & $8 / 1 / 02$ & 1400 & 64.0 & 827 & 750 & 8.6 & -- & 32.4 & 50 & 16.2 & -- & -- \\
\hline & & & $8 / 6 / 02$ & 1430 & 64.0 & -- & 900 & 8.2 & -- & 30.0 & 45 & 9.3 & -- & -- \\
\hline & & & $8 / 7 / 02$ & 850 & 64.0 & -- & 800 & 8.0 & 27.0 & 26.4 & 43 & 6.5 & -- & -- \\
\hline 22 & Buck Creek at Williamstown & 6891060 & $7 / 31 / 02$ & 900 & 58.6 & .2 & 440 & 7.6 & 28.0 & 24.7 & 32 & 4.9 & 4.8 & 2.8 \\
\hline 23 & Kansas River near Midland & 6891070 & $8 / 1 / 02$ & 1120 & 57.5 & -- & 700 & 8.7 & -- & 29.6 & 38 & 11.3 & 11.9 & 8.5 \\
\hline 24 & Kansas River at Lawrence & 6891080 & $8 / 1 / 02$ & 1220 & 51.9 & -- & 670 & 8.7 & -- & 32.0 & 35 & 10.6 & 9.7 & 8.2 \\
\hline
\end{tabular}


Appendix 1. Water-quality results from samples collected from Kansas River, northeast Kansas, selected tributaries, and selected wastewater-treatment facility effluent for synoptic surveys I, II, and III, November 2001 through August 2002.-Continued

$\left[<\right.$, less than; --, not determined; E, estimated; $>$, greater than; $\mathrm{FNU}$, formazin nephelometric units; $\mathrm{CO}_{3}$, carbonate; $\mathrm{HCO}_{3}$, bicarbonate; $\mathrm{CaCO}_{3}$, calcium carbonate; ${ }^{\circ} \mathrm{C}$, degrees Celsius; $\mathrm{SO}_{4}$, sulfate; $\mathrm{Cl}$, chloride, N, nitrogen; P, phosphorus; C, carbon]

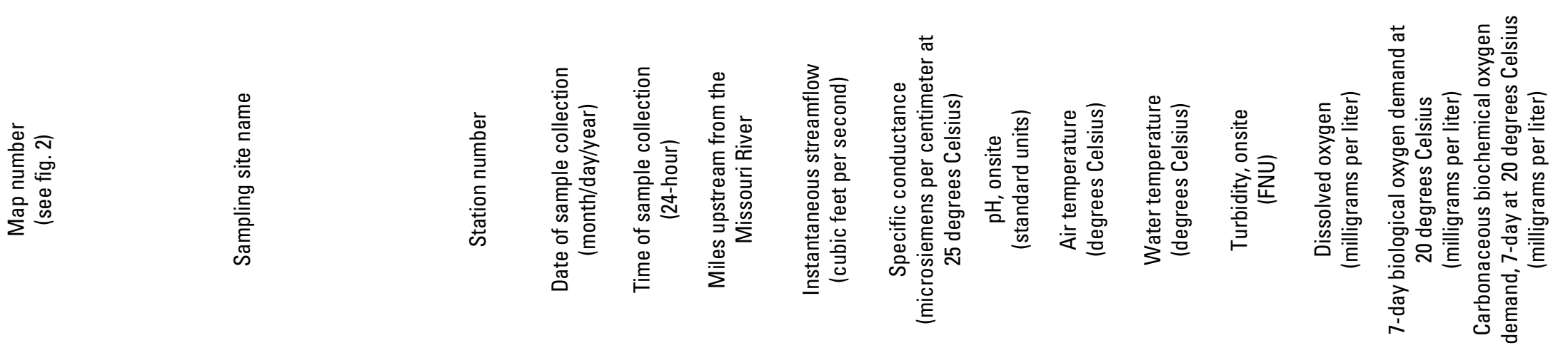

\begin{tabular}{|c|c|c|c|c|c|c|c|c|c|c|c|c|c|c|}
\hline \multicolumn{15}{|c|}{ Synoptic survey III-Continued } \\
\hline 25 & Lawrence wastewater-treatment facility & 6891090 & $7 / 29 / 02$ & 1120 & 51.1 & -- & 960 & 7.5 & 29.0 & 25.1 & 14 & 7.4 & -- & -- \\
\hline \multirow[t]{2}{*}{26} & Kansas River between Lawrence and & 6891093 & $8 / 1 / 02$ & 830 & 50.6 & -- & 740 & 8.5 & -- & 30.2 & 56 & 5.8 & 6.8 & 5.7 \\
\hline & Farmland facility & & $8 / 1 / 02$ & 1100 & 50.6 & -- & 730 & 8.3 & -- & 31.1 & 54 & 6.2 & -- & -- \\
\hline 27 & $\begin{array}{l}\text { Farmland nitrogen wastewater- } \\
\text { treatment facility, Lawrence }\end{array}$ & 6891095 & $7 / 29 / 02$ & 1225 & 50.1 & $<1$ & 1,300 & 8.6 & 36.5 & 30.7 & 74 & 11.2 & -- & -- \\
\hline 28 & Kansas River below Farmland facility & 6891096 & $8 / 1 / 02$ & 930 & 48.6 & -- & 750 & 8.3 & -- & 29.7 & 48 & 5.7 & 7 & 6.0 \\
\hline 29 & Mud Creek near Lawrence & 6891098 & $7 / 31 / 02$ & 825 & 47.6 & 1 & 540 & 7.4 & 26.5 & 26.4 & 26 & 4.6 & 1.8 & 1.5 \\
\hline 30 & Kansas River at Eudora & 6891100 & $7 / 29 / 02$ & 900 & 43.4 & -- & 880 & 8.0 & -- & 26.9 & 50 & 5.5 & -- & -- \\
\hline 31 & $\begin{array}{l}\text { Wakarusa River at } 1900 \text { Road near } \\
\text { Eudora }\end{array}$ & 6891675 & $7 / 30 / 02$ & 820 & 42.6 & 21 & 350 & 7.8 & 24.5 & 27.9 & 79 & 5.5 & 1.5 & 1.0 \\
\hline 32 & Stranger Creek above Linwood & 6892200 & $7 / 30 / 02$ & 1245 & 35.4 & 3.62 & 500 & 8.1 & 33.5 & 30.6 & 34 & 7.5 & 2.4 & 1.9 \\
\hline \multirow[t]{5}{*}{33} & Kansas River at DeSoto & 6892350 & $7 / 25 / 02$ & 1130 & 31.7 & 1,220 & 780 & 8.5 & 33.0 & 27.7 & 48 & 9.2 & -- & -- \\
\hline & & & $7 / 29 / 02$ & 1045 & 31.7 & 1,060 & 850 & 8.2 & 27.0 & 28.6 & 37 & 8.7 & -- & -- \\
\hline & & & $7 / 29 / 02$ & 1330 & 31.7 & 1,020 & 850 & 8.6 & -- & 30.8 & 38 & 10.4 & -- & -- \\
\hline & & & $8 / 2 / 02$ & 700 & 31.7 & 960 & 740 & 8.3 & -- & 27.1 & 36 & -- & -- & -- \\
\hline & & & $8 / 2 / 02$ & 1300 & 31.7 & 960 & 720 & 8.4 & -- & 29.8 & 37 & 8.4 & -- & -- \\
\hline
\end{tabular}


Appendix 1. Water-quality results from samples collected from Kansas River, northeast Kansas, selected tributaries, and selected wastewater-treatment facility effluent for synoptic surveys I, II, and III, November 2001 through August 2002.-Continued

$\left[<\right.$, less than; --, not determined; E, estimated; $>$, greater than; $\mathrm{FNU}$, formazin nephelometric units; $\mathrm{CO}_{3}$, carbonate; $\mathrm{HCO}_{3}$, bicarbonate; $\mathrm{CaCO}_{3}$, calcium carbonate; ${ }^{\circ} \mathrm{C}$, degrees Celsius; $\mathrm{SO}_{4}$, sulfate; $\mathrm{Cl}$, chloride, N, nitrogen; P, phosphorus; C, carbon]

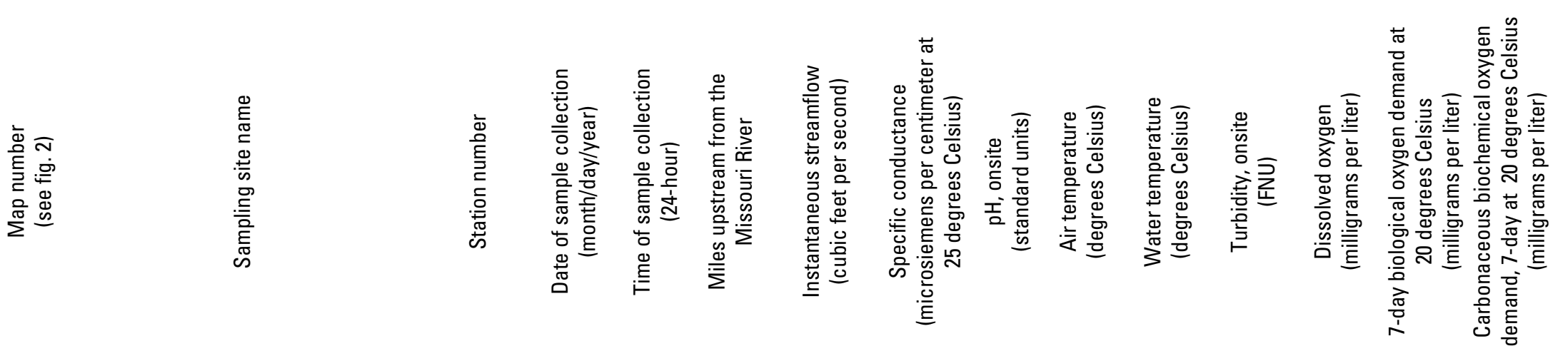

\begin{tabular}{|c|c|c|c|c|c|c|c|c|c|c|c|c|c|c|}
\hline \multicolumn{15}{|c|}{ Synoptic survey III-Continued } \\
\hline \multirow[t]{2}{*}{33} & Kansas River at DeSoto & 6892350 & $8 / 6 / 02$ & 1300 & 31.7 & -- & 870 & 8.7 & -- & 31.0 & 50 & 13.1 & -- & -- \\
\hline & & & $8 / 7 / 02$ & 825 & 31.7 & -- & 863 & 8.3 & -- & 26.7 & 56 & 6.8 & -- & -- \\
\hline 34 & DeSoto wastewater-treatment facility & 6892358 & $7 / 29 / 02$ & 830 & 31.0 & 0.33 & 990 & 7.2 & 23.5 & 26.4 & 5.1 & 3.9 & 11.9 & 5.2 \\
\hline 35 & Kill Creek at 83rd Street & 6892360 & $7 / 30 / 02$ & 850 & 31.0 & .01 & 570 & 7.7 & 25.0 & 24.3 & 31 & 7.3 & 1.7 & $<1$ \\
\hline \multirow[t]{2}{*}{36} & Kansas River near Cedar & 6892380 & $7 / 30 / 02$ & 1200 & 30.8 & -- & 870 & 8.5 & -- & 30.3 & 49 & 9.6 & -- & -- \\
\hline & & & $7 / 30 / 02$ & 1330 & 30.8 & -- & 870 & 8.6 & -- & 31.6 & 50 & 10.7 & 9.0 & 7.5 \\
\hline 37 & Cedar Creek near Cedar Junction & 6892490 & $7 / 30 / 02$ & 920 & 26.7 & 5.32 & 900 & 8.0 & 27.0 & 27.4 & 43 & 6.9 & 1.9 & 1.2 \\
\hline 38 & Kansas River at Bonner Springs & 6892500 & $8 / 6 / 02$ & 910 & 20.7 & -- & 910 & 7.9 & -- & 29.7 & 50 & 5.7 & -- & -- \\
\hline 39 & $\begin{array}{l}\text { Bonner Springs wastewater-treatment } \\
\text { facility }\end{array}$ & 6892502 & $7 / 29 / 02$ & 1330 & 20.3 & 1.34 & 1,300 & 7.2 & -- & 25.1 & 3.0 & 7.3 & 5.4 & 3.8 \\
\hline 40 & Kansas River near Lake of the Forest & 6892504 & $7 / 30 / 02$ & 945 & 19.4 & -- & 870 & 8.3 & -- & 28.6 & 4.4 & 6.2 & 7.0 & 5.0 \\
\hline 41 & Kansas River near Edwardsville & 6892505 & $7 / 30 / 02$ & 900 & 16.6 & -- & 850 & 8.3 & 29.0 & 29.3 & 75 & 5.5 & 5.7 & 5.0 \\
\hline 42 & Mill Creek at Wilder Road & 6892515 & $7 / 30 / 02$ & 1000 & 16.1 & 10.2 & 880 & 7.9 & 30.5 & 27.8 & 24 & 7.2 & 1.6 & 1.4 \\
\hline 43 & Kansas River near I-435 Bridge & 6892518 & $7 / 30 / 02$ & 745 & 15.4 & -- & 840 & 8.2 & 29.0 & 29.2 & 75 & 6.2 & 5.9 & 4.9 \\
\hline 44 & Johnson County Mill Creek wastewater- & 6892520 & $7 / 29 / 02$ & 930 & 15.0 & 10.8 & 1,100 & 7.5 & 24.0 & 28.7 & 7.3 & 3.4 & 21.2 & 4.2 \\
\hline
\end{tabular}


Appendix 1. Water-quality results from samples collected from Kansas River, northeast Kansas, selected tributaries, and selected wastewater-treatment facility effluent for synoptic surveys I, II, and III, November 2001 through August 2002.-Continued

$\left[<\right.$, less than; --, not determined; E, estimated; $>$, greater than; $\mathrm{FNU}$, formazin nephelometric units; $\mathrm{CO}_{3}$, carbonate; $\mathrm{HCO}_{3}$, bicarbonate; $\mathrm{CaCO}_{3}$, calcium carbonate; ${ }^{\circ} \mathrm{C}$, degrees Celsius; $\mathrm{SO}_{4}$, sulfate; $\mathrm{Cl}$, chloride, N, nitrogen; P, phosphorus; C, carbon]

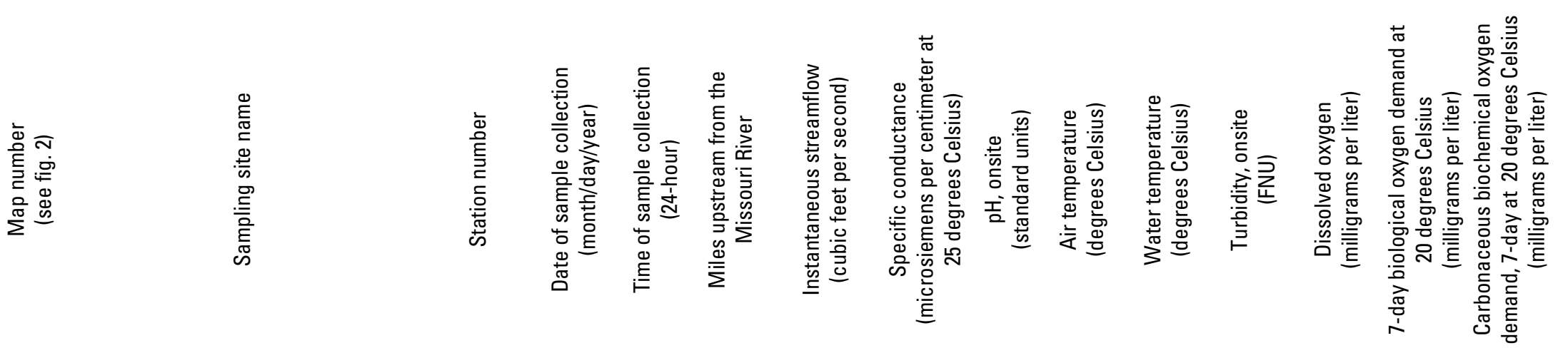

\begin{tabular}{|c|c|c|c|c|c|c|c|c|c|c|c|c|c|c|}
\hline \multicolumn{15}{|c|}{ Synoptic survey III-Continued } \\
\hline 45 & $\begin{array}{l}\text { Kansas City wastewater-treatment } \\
\text { facility no. } 20\end{array}$ & 6892525 & $7 / 29 / 02$ & 835 & 14.8 & -- & 1,200 & 7.1 & 24.5 & 23.7 & 0.5 & 3.2 & 3.5 & 1.8 \\
\hline 46 & $\begin{array}{c}\text { Unnamed tributary below Kansas City } \\
\text { wastewater-treatment facility no. } 14\end{array}$ & 6892527 & $7 / 29 / 02$ & 900 & 11.2 & 0.07 & 970 & 7.9 & 24.5 & 24.4 & 55 & 6.6 & 10.9 & 2.7 \\
\hline \multirow[t]{3}{*}{47} & Kansas River at Turner Bridge & 6892530 & $7 / 26 / 02$ & 850 & 9.7 & -- & 800 & 7.7 & 30.0 & 28.9 & 58 & -- & -- & -- \\
\hline & & & $7 / 29 / 02$ & 1030 & 9.7 & -- & 830 & 7.9 & 30.0 & 28.3 & 61 & 5.2 & 7.2 & 4.6 \\
\hline & & & $8 / 8 / 02$ & 1055 & 9.7 & -- & 880 & 8.0 & -- & 27.3 & 79 & 6.0 & -- & -- \\
\hline \multirow[t]{2}{*}{48} & $\begin{array}{l}\text { Kansas River at west Kansas Avenue } \\
\text { Bridge }\end{array}$ & 6892540 & $7 / 29 / 02$ & 1135 & 6.0 & -- & 830 & 7.8 & -- & 28.9 & 46 & 5.7 & 11.5 & 5.9 \\
\hline & & & $8 / 8 / 02$ & 1150 & 6.0 & -- & 900 & 8.0 & -- & 27.6 & 67 & 7.5 & -- & -- \\
\hline 49 & Turkey Creek at Kansas City near I-35 & 6892942 & $7 / 30 / 02$ & 1100 & 3.2 & 22 & 940 & 7.3 & 33.5 & 25.8 & 11 & 7.0 & 16.5 & 12.1 \\
\hline \multirow[t]{4}{*}{50} & Kansas River above Missouri River & 6892960 & $7 / 26 / 02$ & 1035 & 1.1 & -- & 780 & 7.6 & 33.0 & 29.1 & 45 & 4.6 & -- & -- \\
\hline & confluence & & $7 / 29 / 02$ & 830 & 1.1 & -- & 810 & 7.6 & 27.0 & 28.4 & 38 & 4.3 & 7.8 & 5.6 \\
\hline & & & 8/7/02 & 1325 & 1.1 & -- & 870 & 7.6 & -- & 21.4 & 71 & 8.1 & -- & -- \\
\hline & & & $8 / 8 / 02$ & 900 & 1.1 & -- & 930 & 7.7 & -- & 27.9 & 78 & 5.7 & -- & -- \\
\hline
\end{tabular}


Appendix 1. Water-quality results from samples collected from Kansas River, northeast Kansas, selected tributaries, and selected wastewater-treatment facility effluent for synoptic surveys I, II, and III, November 2001 through August 2002.-Continued

$\left[<\right.$, less than; --, not determined; E, estimated; >, greater than; $\mathrm{FNU}$, formazin nephelometric units; $\mathrm{CO}_{3}$, carbonate; $\mathrm{HCO}_{3}$, bicarbonate; $\mathrm{CaCO}{ }_{3}$, calcium carbonate; ${ }^{\circ} \mathrm{C}$, degrees $\mathrm{Celsius;} \mathrm{SO}{ }_{4}$, sulfate; $\mathrm{Cl}$, chloride; $\mathrm{N}$, nitrogen; P, phosphorus; C, carbon]

\begin{tabular}{|c|c|c|c|c|c|c|c|c|c|c|c|}
\hline 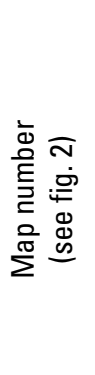 & 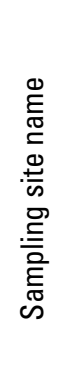 & 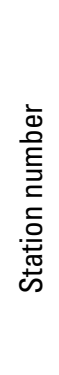 & 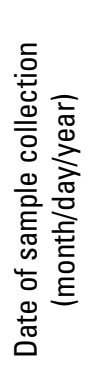 & 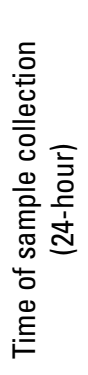 & 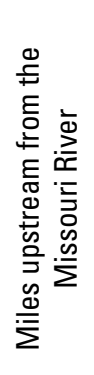 & 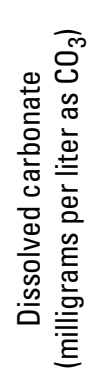 & 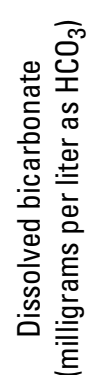 & 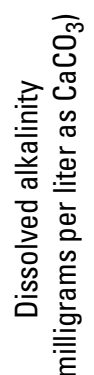 & 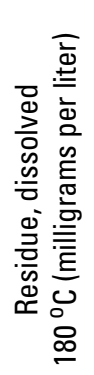 & 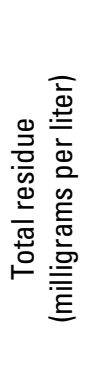 & 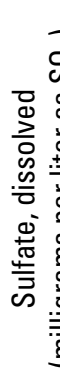 \\
\hline
\end{tabular}

\begin{tabular}{|c|c|c|c|c|c|c|c|c|c|c|c|c|c|c|c|}
\hline \multicolumn{16}{|c|}{ Synoptic survey I } \\
\hline 10 & Kansas River at Highway 75, Topeka & 6888980 & $11 / 29 / 01$ & 1100 & 86.0 & 0 & 230 & 190 & 610 & $<10$ & 120 & 120 & 0.33 & $<0.01$ & 0.62 \\
\hline 11 & North Topeka wastewater-treatment facility & 6888985 & $11 / 28 / 01$ & 1220 & 85.0 & 0 & 170 & 140 & 728 & 14 & 130 & 150 & .87 & .26 & E. 27 \\
\hline 13 & Topeka Oakland wastewater-treatment facility & 6889002 & $11 / 28 / 01$ & 1115 & 81.7 & 0 & 280 & 230 & 676 & $<10$ & 120 & 140 & .91 & .42 & .45 \\
\hline 15 & Soldier Creek, Meriden Road, near Topeka & 6889504 & $11 / 29 / 01$ & 930 & 80.5 & 0 & 310 & 250 & 418 & $<10$ & 73 & 38 & .28 & .01 & .27 \\
\hline 16 & Shunganunga Creek at Rice Road, Topeka & 6889700 & $11 / 29 / 01$ & 1030 & 76.0 & 0 & 180 & 150 & 360 & $<10$ & 74 & 41 & .23 & .01 & .24 \\
\hline 18 & Muddy Creek near Grantville & 6889800 & $11 / 28 / 01$ & 850 & 72.3 & 0 & 320 & 260 & 322 & $<10$ & 51 & 13 & .23 & $<.01$ & .12 \\
\hline 20 & Delaware River below Perry Dam & 6890900 & $11 / 28 / 01$ & 920 & 65.1 & 0 & 120 & 100 & 162 & 36 & 13 & 4.9 & .23 & $<.01$ & .63 \\
\hline 21 & Kansas River at Lecompton & 6891000 & $11 / 28 / 01$ & 1330 & 64.0 & 0 & 230 & 190 & 580 & 22 & 110 & 100 & .31 & .06 & .72 \\
\hline 25 & Lawrence wastewater-treatment facility & 6891090 & $11 / 28 / 01$ & 920 & 51.1 & 0 & 170 & 140 & 574 & 32 & 81 & 96 & .79 & .17 & 12 \\
\hline 27 & $\begin{array}{l}\text { Farmland nitrogen wastewater-treatment } \\
\text { facility, Lawrence }\end{array}$ & 6891095 & $11 / 28 / 01$ & 845 & 50.1 & 0 & 130 & 100 & 1152 & 44 & 500 & 74 & .75 & .53 & 30 \\
\hline 29 & Mud Creek near Lawrence & 6891098 & $11 / 27 / 01$ & 1145 & 47.6 & 0 & 270 & 220 & 300 & 12 & 44 & 13 & .23 & $<.01$ & .11 \\
\hline 30 & Kansas River at Eudora & 6891100 & $11 / 28 / 01$ & 1030 & 43.4 & 0 & 230 & 190 & 496 & 10 & 94 & 76 & .36 & .05 & .94 \\
\hline 31 & Wakarusa River at 1900 Road near Eudora & 6891675 & $11 / 27 / 01$ & 755 & 42.6 & 0 & 240 & 190 & 268 & 18 & 30 & 21 & .21 & $<.01$ & .04 \\
\hline 32 & Stranger Creek above Linwood & 6892200 & $11 / 27 / 01$ & 1240 & 35.4 & 0 & 290 & 240 & 286 & $<10$ & 28 & 13 & .20 & $<.01$ & .11 \\
\hline 35 & Kill Creek at 83rd Street & 6892360 & $11 / 27 / 01$ & 1015 & 31.0 & 0 & 310 & 250 & 360 & 10 & 58 & 21 & .16 & $<.01$ & .01 \\
\hline
\end{tabular}


[<, less than; --, not determined; E, estimated; >, greater than; $\mathrm{FNU}$, formazin nephelometric units; $\mathrm{CO}_{3}$, carbonate; $\mathrm{HCO}_{3}$, bicarbonate; $\mathrm{CaCO}{ }_{3}$, calcium carbonate; ${ }^{\circ} \mathrm{C}$, degrees $\mathrm{Celsius;} \mathrm{SO} 4$, sulfate; $\mathrm{Cl}$, chloride; $\mathrm{N}$, nitrogen; $\mathrm{P}$, phosphorus; $\mathrm{C}$, carbon]

\begin{tabular}{|c|c|c|c|c|c|c|c|c|c|c|c|c|c|c|c|}
\hline 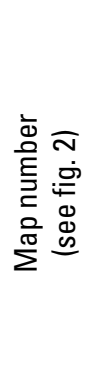 & 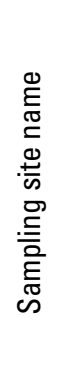 & 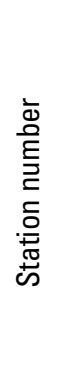 & 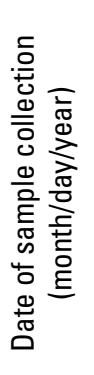 & 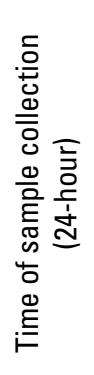 & 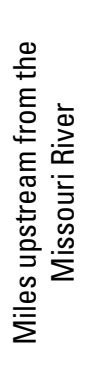 & 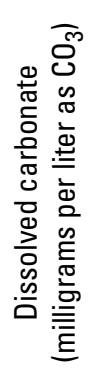 & 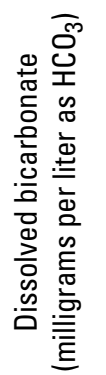 & 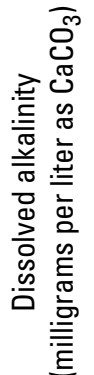 & 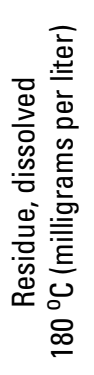 & 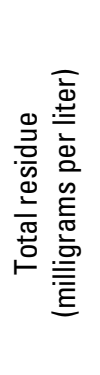 & 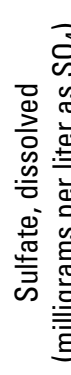 & 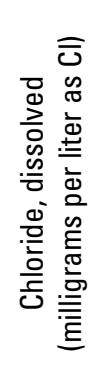 & 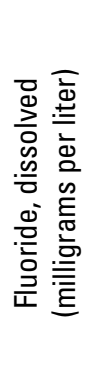 & 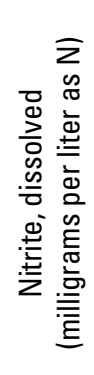 & 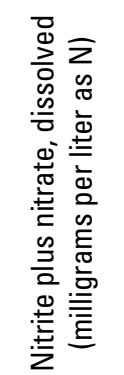 \\
\hline
\end{tabular}

Synoptic survey I-Continued

\begin{tabular}{|c|c|}
\hline 37 & Cedar Creek near Cedar Junction \\
\hline 39 & Bonner Springs wastewater-treatr \\
\hline & Mill Creek at Wilder Road \\
\hline 44 & $\begin{array}{l}\text { Johnson County Mill Creek wast } \\
\text { treatment facility }\end{array}$ \\
\hline 45 & $\begin{array}{l}\text { Kansas City wastewater-treatmen } \\
\text { facility no. } 20\end{array}$ \\
\hline 46 & $\begin{array}{c}\text { Unnamed tributary below Kansas } \\
\text { water-treatment facility no. } 14\end{array}$ \\
\hline 48 & Kansas River at west Kansas Ave \\
\hline 49 & Turkey Creek at Kansas City nea \\
\hline 50 & $\begin{array}{l}\text { Kansas River above Missouri Ri } \\
\text { confluence }\end{array}$ \\
\hline 2 & Vermillion Creek near Wamego \\
\hline 3 & Rock Creek near Louisville \\
\hline 4 & Kansas River at Belvue \\
\hline 5 & Kansas River near Maple Hill \\
\hline 6 & Mill Creek near Maple Hill \\
\hline 7 & Cross Creek near Rossville \\
\hline
\end{tabular}

$\begin{array}{llllll}6888700 & 2 / 28 / 02 & 1400 & 100.1 & 0 & 320\end{array}$

\begin{tabular}{|c|c|c|c|c|c|c|c|c|c|c|c|c|c|}
\hline 6892490 & $11 / 27 / 01$ & 830 & 26.7 & 0 & 240 & 190 & 614 & 26 & 140 & 92 & 0.40 & 0.03 & 5.8 \\
\hline 6892502 & $11 / 29 / 01$ & 1010 & 20.3 & 0 & 290 & 240 & 792 & 20 & 130 & 170 & .48 & .01 & .30 \\
\hline 6892515 & $11 / 27 / 01$ & 845 & 16.1 & 0 & 150 & 130 & 380 & 38 & 68 & 71 & .23 & .04 & 2.9 \\
\hline 6892520 & 11/27/01 & 1215 & 15.0 & 0 & 210 & 180 & 634 & 20 & 180 & 96 & .69 & .29 & 3.6 \\
\hline 6892525 & $11 / 27 / 01$ & 930 & 14.8 & 0 & 240 & 200 & 744 & $<10$ & 160 & 110 & .90 & .30 & 8.4 \\
\hline 6892527 & $11 / 27 / 01$ & 1100 & 11.2 & 0 & 330 & 270 & 544 & 712 & 73 & 72 & .24 & .02 & 3.9 \\
\hline 6892540 & $11 / 28 / 01$ & 1010 & 6.0 & 0 & 230 & 190 & 460 & 10 & 86 & 73 & .35 & .04 & .87 \\
\hline 6892942 & $11 / 27 / 01$ & 1030 & 3.2 & 0 & 140 & 120 & 618 & 10 & 170 & 95 & .71 & .57 & 7.3 \\
\hline 6892960 & $11 / 27 / 01$ & 1230 & 1.1 & 0 & 210 & 170 & 476 & 24 & 88 & 76 & .31 & .04 & .88 \\
\hline \multicolumn{14}{|c|}{ Synoptic survey II } \\
\hline 6888000 & $2 / 28 / 02$ & 1310 & 119.2 & 0 & 340 & 280 & 366 & $<10$ & 64 & 11 & -- & .01 & .15 \\
\hline 6888300 & $2 / 28 / 02$ & 1215 & 118.2 & 0 & 220 & 180 & 346 & 12 & 65 & 13 & -- & $<.01$ & .14 \\
\hline 6888350 & $2 / 28 / 02$ & 1315 & 113.0 & 0 & 250 & 210 & 636 & 32 & 150 & 130 & -- & .01 & .70 \\
\hline 6888400 & $2 / 28 / 02$ & 1135 & 103.7 & 0 & 250 & 210 & 648 & 64 & 150 & 130 & -- & .01 & .64 \\
\hline 6888650 & $2 / 28 / 02$ & 1015 & 101.7 & 0 & 310 & 250 & 410 & 16 & 100 & 17 & -- & $<.01$ & $<.01$ \\
\hline
\end{tabular}


Appendix 1. Water-quality results from samples collected from Kansas River, northeast Kansas, selected tributaries, and selected wastewater-treatment facility effluent for synoptic surveys I, II, and III, November 2001 through August 2002.-Continued

$\left[<\right.$, less than; --, not determined; E, estimated; $>$, greater than; $\mathrm{FNU}$, formazin nephelometric units; $\mathrm{CO}_{3}$, carbonate; $\mathrm{HCO}_{3}$, bicarbonate; $\mathrm{CaCO}_{3}$, calcium carbonate; ${ }^{\circ} \mathrm{C}$, degrees $\mathrm{Cel}$ sius; $\mathrm{SO}{ }_{4}$, sulfate; $\mathrm{Cl}$, chloride; $\mathrm{N}$, nitrogen; $\mathrm{P}$, phosphorus; $\mathrm{C}$, carbon]

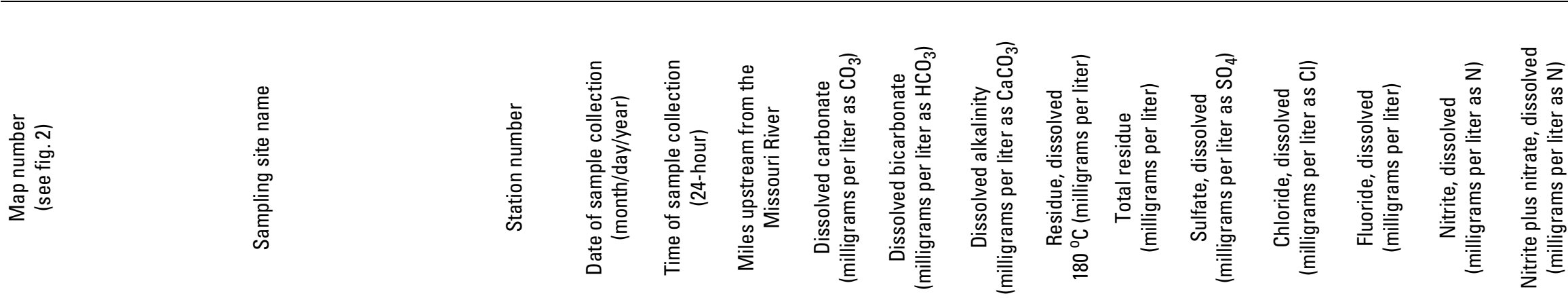

\begin{tabular}{|c|c|c|c|c|c|c|c|c|c|c|c|c|c|c|c|}
\hline \multicolumn{16}{|c|}{ Synoptic survey II-Continued } \\
\hline 8 & Kansas River at Willard & 6888705 & $2 / 28 / 02$ & 950 & 98.9 & 0 & 250 & 210 & 636 & 54 & 150 & 120 & -- & 0.01 & 0.61 \\
\hline 9 & Mission Creek near Valencia & 6888800 & $2 / 28 / 02$ & 900 & 91.6 & 0 & 330 & 270 & 338 & $<10$ & 59 & 12 & -- & $<.01$ & .12 \\
\hline 10 & Kansas River at Highway 75, Topeka & 6888980 & $2 / 28 / 02$ & 1115 & 86.0 & 0 & 200 & 170 & 632 & 48 & 150 & 130 & -- & .01 & .53 \\
\hline 11 & North Topeka wastewater-treatment facility & 6888985 & $2 / 26 / 02$ & 1130 & 85.0 & 0 & 170 & 140 & 780 & 12 & 170 & 170 & -- & .21 & 9.3 \\
\hline 12 & Kansas River at Topeka & 6889000 & $2 / 27 / 02$ & 1320 & 83.0 & 0 & 250 & 200 & 632 & 38 & 150 & 120 & -- & .02 & .48 \\
\hline 13 & Topeka Oakland wastewater-treatment facility & 6889002 & $2 / 26 / 02$ & 1045 & 81.7 & 0 & 370 & 300 & 748 & 12 & 170 & 170 & -- & $<.12$ & $<.65$ \\
\hline 14 & Kansas River at Highway 4, Topeka & 6889010 & $2 / 28 / 02$ & 855 & 81.1 & 0 & 250 & 200 & 636 & 40 & 150 & 120 & -- & .02 & .53 \\
\hline 15 & Soldier Creek, Meriden Road, near Topeka & 6889504 & $2 / 27 / 02$ & 1215 & 80.5 & 0 & 340 & 270 & 496 & 14 & 84 & 61 & -- & .02 & .28 \\
\hline 16 & Shunganunga Creek at Rice Road, Topeka & 6889700 & $2 / 27 / 02$ & 1315 & 76.0 & 0 & 270 & 220 & 472 & 18 & 100 & 65 & -- & .01 & .24 \\
\hline 17 & Kansas River near Grantville & 6889750 & $2 / 28 / 02$ & 1100 & 73.7 & 3.8 & 250 & 210 & 648 & 38 & 150 & 120 & -- & .02 & .52 \\
\hline 18 & Muddy Creek near Grantville & 6889800 & $2 / 27 / 02$ & 900 & 72.3 & 0 & 340 & 280 & 406 & $<10$ & 70 & 18 & -- & $<.01$ & .16 \\
\hline 19 & Kansas River near Grover & 6889850 & $2 / 28 / 02$ & 1330 & 68.6 & 0 & 250 & 200 & 640 & 40 & 150 & 120 & -- & .02 & .50 \\
\hline 20 & Delaware River below Perry Dam & 6890900 & $2 / 27 / 02$ & 930 & 65.1 & -- & -- & -- & 172 & 12 & 16 & 5.0 & -- & $<.01$ & .32 \\
\hline 21 & Kansas River at Lecompton & 6891000 & $2 / 27 / 02$ & 1025 & 64.0 & 4.8 & 250 & 210 & 624 & 48 & 150 & 110 & -- & .01 & .30 \\
\hline 22 & Buck Creek at Williamstown & 6891060 & $2 / 27 / 02$ & 1015 & 58.6 & 0 & 310 & 250 & 324 & $<10$ & 41 & 8.3 & -- & .01 & .61 \\
\hline 23 & Kansas River near Midland & 6891070 & $3 / 1 / 02$ & 935 & 57.5 & 0 & 240 & 200 & 616 & 38 & 140 & 110 & -- & .02 & .52 \\
\hline 24 & Kansas River at Lawrence & 6891080 & $2 / 27 / 02$ & 1020 & 51.9 & 7.2 & 230 & 200 & 610 & 42 & 150 & 120 & -- & .02 & .18 \\
\hline 25 & Lawrence wastewater-treatment facility & 6891090 & $2 / 25 / 02$ & 1305 & 51.1 & 0 & 170 & 140 & 636 & 18 & 150 & 130 & -- & 69 & 7.7 \\
\hline
\end{tabular}


[<, less than; --, not determined; E, estimated; >, greater than; $\mathrm{FNU}$, formazin nephelometric units; $\mathrm{CO}_{3}$, carbonate; $\mathrm{HCO}_{3}$, bicarbonate; $\mathrm{CaCO}{ }_{3}$, calcium carbonate; ${ }^{\circ} \mathrm{C}$, degrees $\mathrm{Celsius;} \mathrm{SO}$, sulfate; $\mathrm{Cl}_{\text {, chloride; }}$ $\mathrm{N}$, nitrogen; $\mathrm{P}$, phosphorus; $\mathrm{C}$, carbon]

\begin{tabular}{|c|c|c|c|c|c|c|c|c|c|c|c|c|c|c|c|}
\hline 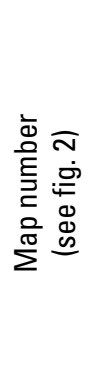 & 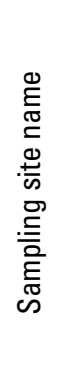 & 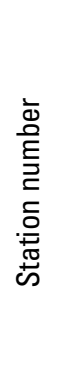 & 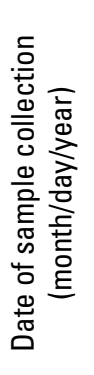 & 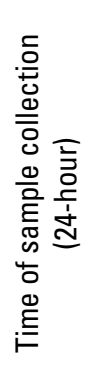 & 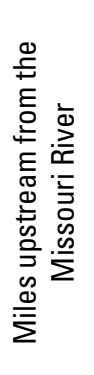 & 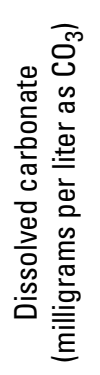 & 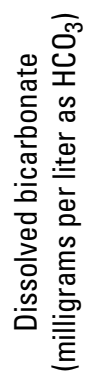 & 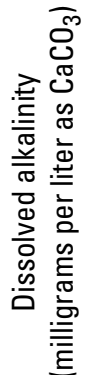 & 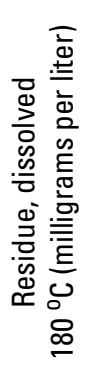 & 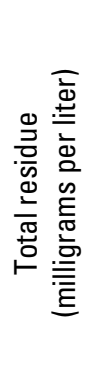 & 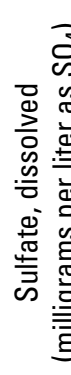 & 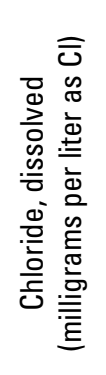 & 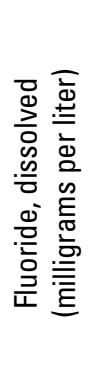 & 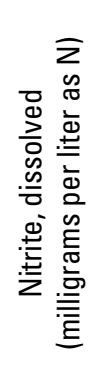 & 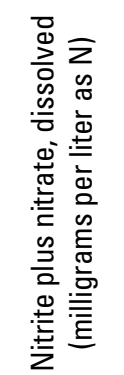 \\
\hline
\end{tabular}

\begin{tabular}{ll}
\hline 26 & $\begin{array}{l}\text { Kansas River between Lawrence and } \\
\text { Farmland facility }\end{array}$ \\
27 & $\begin{array}{l}\text { Farmland nitrogen wastewater-treatment } \\
\text { facility, Lawrence }\end{array}$ \\
28 & Kansas River below Farmland facility \\
29 & Mud Creek near Lawrence \\
30 & Kansas River at Eudora \\
& \\
31 & Wakarusa River at 1900 Road near Eudora \\
32 & Stranger Creek above Linwood \\
33 & Kansas River at DeSoto \\
34 & DeSoto wastewater-treatment facility \\
35 & Kill Creek at 83rd Street \\
& \\
36 & Kansas River near Cedar \\
37 & Cedar Creek near Cedar Junction \\
38 & Kansas River at Bonner Springs \\
39 & Bonner Springs wastewater-treatment facility \\
40 & Kansas River near Lake of the Forest \\
&
\end{tabular}

Synoptic survey II-Continued

$\begin{array}{rlllllllllllllll}6891093 & 2 / 27 / 02 & 1115 & 50.6 & 12.5 & 230 & 210 & 610 & 30 & 140 & 110 & -- & 0.02 & 0.25 \\ 6891095 & 2 / 26 / 02 & 840 & 50.1 & 0 & 23 & 19 & 1,380 & 50 & 640 & 110 & -- & .42 & 40 \\ & & & & & & & & & & & & & \\ 6891096 & 2 / 27 / 02 & 1300 & 48.6 & 7.7 & 240 & 210 & 610 & 30 & 140 & 110 & -- & .02 & .24 \\ 6891098 & 2 / 26 / 02 & 1045 & 47.6 & 0 & 290 & 240 & 316 & 14 & 35 & 12 & -- & <.01 & .05 \\ 6891100 & 2 / 25 / 02 & 930 & 43.4 & 20.0 & 190 & 190 & 590 & 44 & 140 & 100 & -- & .02 & .13 \\ & & & & & & & & & & & & & \\ 6891675 & 2 / 26 / 02 & 900 & 42.6 & 0 & 200 & 160 & 272 & 20 & 34 & 25 & -- & \text { E<.01 } & .03 \\ 6892200 & 2 / 26 / 02 & 1145 & 35.4 & 0 & 250 & 210 & 322 & 14 & 33 & 15 & -- & .02 & .87 \\ 6892350 & 2 / 25 / 02 & 1230 & 31.7 & 13.4 & 200 & 190 & 570 & 66 & 130 & 98 & -- & .01 & .10 \\ 6892358 & 2 / 25 / 02 & 830 & 31.0 & 0 & 180 & 150 & 530 & 16 & 82 & 130 & -- & .02 & 1.0 \\ 6892360 & 2 / 25 / 02 & 915 & 31.0 & 0 & 220 & 180 & 336 & 24 & 49 & 27 & -- & .01 & .19 \\ & & & & & & & & & & & & -19 \\ 6892380 & 2 / 26 / 02 & 1230 & 30.8 & 13.4 & 190 & 180 & 580 & 56 & 130 & 100 & -- & <.01 & \text { E.01 } \\ 6892490 & 2 / 25 / 02 & 1315 & 26.7 & 3.8 & 210 & 180 & 484 & 22 & 100 & 64 & -- & .02 & 1.4 \\ 6892500 & 2 / 26 / 02 & 1030 & 20.7 & 14.4 & 220 & 210 & 548 & 80 & 130 & 100 & -- & <.01 & <.01 \\ 6892502 & 2 / 26 / 02 & 945 & 20.3 & 0 & 290 & 240 & 764 & <10 & 130 & 150 & -- & .05 & 5.7 \\ 6892504 & 2 / 26 / 02 & 1005 & 19.4 & 12.5 & 190 & 170 & 558 & 82 & 130 & 100 & -- & <.01 & <.01 \\ 6892505 & 2 / 26 / 02 & 1130 & 16.6 & 14.4 & 230 & 210 & 546 & 82 & 130 & 100 & -- & <.01 & <.01\end{array}$


Appendix 1. Water-quality results from samples collected from Kansas River, northeast Kansas, selected tributaries, and selected wastewater-treatment facility effluent for synoptic surveys I, II, and III, November 2001 through August 2002.-Continued

$\left[<\right.$, less than; --, not determined; E, estimated; $>$, greater than; $\mathrm{FNU}$, formazin nephelometric units; $\mathrm{CO}_{3}$, carbonate; $\mathrm{HCO}_{3}$, bicarbonate; $\mathrm{CaCO}_{3}$, calcium carbonate; ${ }^{\circ} \mathrm{C}$, degrees $\mathrm{Cel}$ sius; $\mathrm{SO}{ }_{4}$, sulfate; $\mathrm{Cl}$, chloride; $\mathrm{N}$, nitrogen; $\mathrm{P}$, phosphorus; $\mathrm{C}$, carbon]

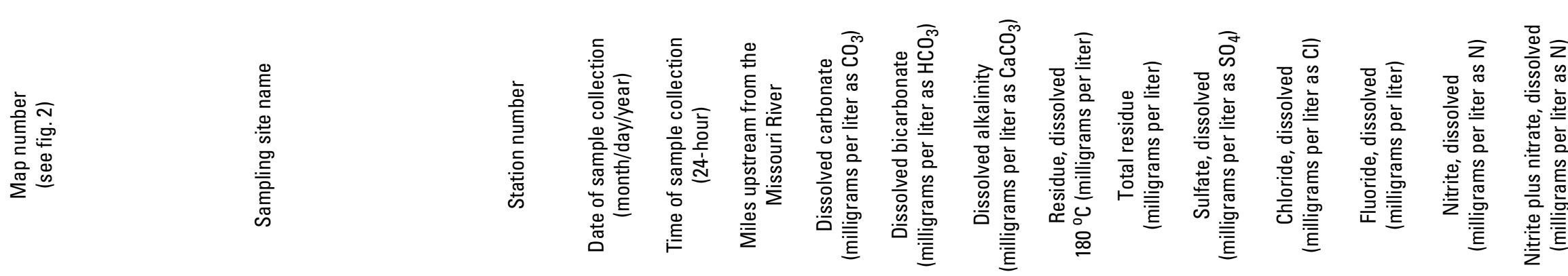

\begin{tabular}{|c|c|c|c|c|c|c|c|c|c|c|c|c|c|c|c|}
\hline \multicolumn{16}{|c|}{ Synoptic survey II-Continued } \\
\hline 42 & Mill Creek at Wilder Road & 6892515 & $2 / 25 / 02$ & 1015 & 16.1 & 0 & 230 & 190 & 552 & 18 & 80 & 120 & -- & 0.01 & 1.0 \\
\hline 43 & Kansas River near I-435 Bridge & 6892518 & $2 / 26 / 02$ & 925 & 15.4 & 14.4 & 280 & 210 & 538 & 66 & 130 & 96 & -- & $<.01$ & $<.01$ \\
\hline 44 & $\begin{array}{l}\text { Johnson County Mill Creek wastewater- } \\
\text { treatment facility }\end{array}$ & 6892520 & $2 / 25 / 02$ & 1150 & 15.0 & 0 & 270 & 220 & 652 & 28 & 140 & 130 & -- & .04 & .19 \\
\hline 45 & $\begin{array}{l}\text { Kansas City wastewater-treatment facility } \\
\text { no. } 20\end{array}$ & 6892525 & $2 / 25 / 02$ & 1000 & 14.8 & 0 & 270 & 220 & 744 & $<10$ & 140 & 120 & -- & .40 & 10 \\
\hline 46 & $\begin{array}{l}\text { Unnamed tributary below Kansas City } \\
\text { wastewater-treatment facility no. } 14\end{array}$ & 6892527 & $2 / 25 / 02$ & 1030 & 11.2 & 0 & 300 & 240 & 454 & $<10$ & 56 & 62 & -- & $<.01$ & .32 \\
\hline 47 & Kansas River at Turner Bridge & 6892530 & $2 / 25 / 02$ & 1235 & 9.7 & 21.1 & 180 & 190 & 512 & 92 & 120 & 86 & -- & .02 & .11 \\
\hline 48 & Kansas River at west Kansas Avenue Bridge & 6892540 & $2 / 25 / 02$ & 1050 & 6.0 & 27.8 & 150 & 170 & 474 & 102 & 110 & 84 & -- & .02 & .17 \\
\hline 49 & Turkey Creek at Kansas City near I-35 & 6892942 & $2 / 25 / 02$ & 1120 & 3.2 & 0 & 170 & 140 & 648 & $<10$ & 130 & 140 & -- & .32 & 6.9 \\
\hline 50 & $\begin{array}{l}\text { Kansas River above Missouri River } \\
\text { confluence }\end{array}$ & 6892960 & $2 / 25 / 02$ & 745 & 1.1 & -- & -- & -- & 512 & 92 & 110 & 79 & -- & .02 & .40 \\
\hline \multicolumn{16}{|c|}{ Synoptic survey III } \\
\hline 1 & Kansas River at Wamego & 6887500 & $7 / 31 / 02$ & 1005 & 124.0 & -- & -- & -- & -- & -- & -- & -- & -- & $<.01$ & $<.01$ \\
\hline 2 & Vermillion Creek near Wamego & 6888000 & $8 / 1 / 02$ & 1020 & 119.2 & -- & -- & -- & -- & -- & -- & -- & -- & $<.01$ & $<.01$ \\
\hline 3 & Rock Creek near Louisville & 6888300 & $8 / 1 / 02$ & 945 & 118.2 & -- & -- & -- & -- & -- & -- & -- & -- & $\mathrm{E}<.01$ & .02 \\
\hline 4 & Kansas River at Belvue & 6888350 & $7 / 31 / 02$ & 1205 & 113.0 & -- & -- & -- & -- & -- & -- & -- & -- & $<.01$ & $<.01$ \\
\hline 5 & Kansas River near Maple Hill & 6888400 & $7 / 31 / 02$ & 750 & 103.7 & -- & -- & -- & -- & -- & -- & -- & -- & $<.01$ & $<.01$ \\
\hline 6 & Mill Creek near Maple Hill & 6888650 & $8 / 1 / 02$ & 1130 & 101.7 & -- & -- & -- & -- & -- & -- & -- & -- & $<.01$ & $<.01$ \\
\hline
\end{tabular}


[<, less than; --, not determined; E, estimated; >, greater than; $\mathrm{FNU}$, formazin nephelometric units; $\mathrm{CO}_{3}$, carbonate; $\mathrm{HCO}_{3}$, bicarbonate; $\mathrm{CaCO} 3$, calcium carbonate; ${ }^{\circ} \mathrm{C}$, degrees $\mathrm{Celsius;} \mathrm{SO}{ }_{4}$, sulfate; $\mathrm{Cl}_{\text {, chloride; }}$ $\mathrm{N}$, nitrogen; P, phosphorus; C, carbon]

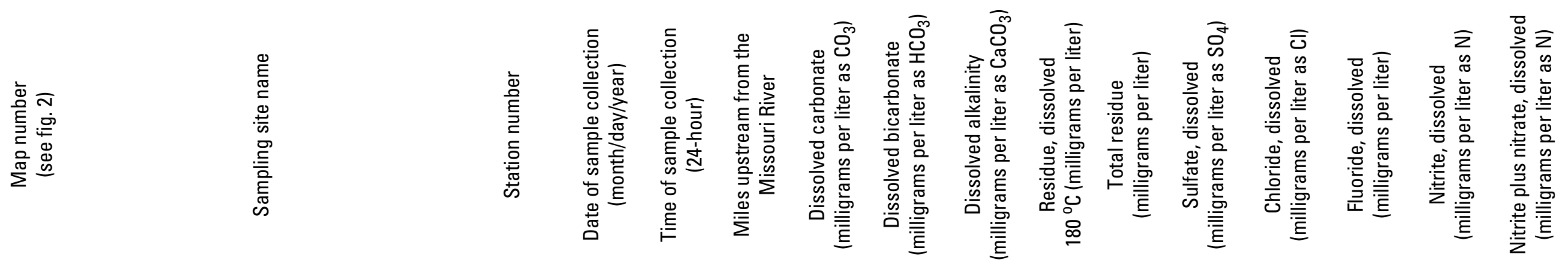

\begin{tabular}{|c|c|c|c|c|c|c|c|c|c|c|c|c|c|c|c|}
\hline \multicolumn{16}{|c|}{ Synoptic survey III-Continued } \\
\hline 7 & Cross Creek near Rossville & 6888700 & $7 / 31 / 02$ & 1155 & 100.1 & -- & -- & -- & -- & -- & -- & -- & -- & 0.01 & 0.06 \\
\hline 8 & Kansas River at Willard & 6888705 & $7 / 31 / 02$ & 1020 & 98.9 & -- & -- & -- & -- & -- & -- & -- & -- & $<.01$ & $<.01$ \\
\hline 9 & Mission Creek near Valencia & 6888800 & $8 / 1 / 02$ & 1210 & 91.6 & -- & -- & -- & -- & -- & -- & -- & -- & $<.01$ & .01 \\
\hline 10 & Kansas River at Highway 75, Topeka & 6888980 & $7 / 31 / 02$ & 1220 & 86.0 & -- & -- & -- & -- & -- & -- & -- & -- & $<.01$ & $<.01$ \\
\hline 11 & North Topeka wastewater-treatment facility & 6888985 & $7 / 30 / 02$ & 845 & 85.0 & -- & -- & -- & -- & -- & -- & -- & -- & .01 & 24 \\
\hline \multirow[t]{5}{*}{12} & Kansas River at Topeka & 6889000 & $7 / 23 / 02$ & 1005 & 83.0 & -- & -- & -- & -- & -- & -- & -- & -- & $<.01$ & $<.01$ \\
\hline & & & $8 / 2 / 02$ & 855 & 83.0 & -- & -- & -- & -- & -- & -- & -- & -- & $<.01$ & .01 \\
\hline & & & $8 / 2 / 02$ & 1500 & 83.0 & -- & -- & -- & -- & -- & -- & -- & -- & .01 & .20 \\
\hline & & & $8 / 5 / 02$ & 1515 & 83.0 & -- & -- & -- & -- & -- & -- & -- & -- & .01 & .19 \\
\hline & & & $8 / 6 / 02$ & 900 & 83.0 & -- & -- & -- & -- & -- & -- & -- & -- & .01 & .11 \\
\hline 13 & Topeka Oakland wastewater-treatment facility & 6889002 & $7 / 30 / 02$ & 815 & 81.7 & -- & -- & -- & -- & -- & -- & -- & -- & .01 & .02 \\
\hline \multirow[t]{2}{*}{14} & Kansas River at Highway 4, Topeka & 6889010 & $7 / 31 / 02$ & 1340 & 81.1 & -- & -- & -- & -- & -- & -- & -- & -- & .03 & .23 \\
\hline & & & $8 / 1 / 02$ & 735 & 81.1 & -- & -- & -- & -- & -- & -- & -- & -- & .02 & .27 \\
\hline 15 & Soldier Creek, Meriden Road, near Topeka & 6889504 & $7 / 31 / 02$ & 1300 & 80.5 & -- & -- & -- & -- & -- & -- & -- & -- & .01 & .05 \\
\hline 16 & Shunganunga Creek at Rice Road, Topeka & 6889700 & $7 / 31 / 02$ & 1040 & 76.0 & -- & -- & -- & -- & -- & -- & -- & -- & .05 & .21 \\
\hline 17 & Kansas River near Grantville & 6889750 & $7 / 31 / 02$ & 1100 & 73.7 & -- & -- & -- & -- & -- & -- & -- & -- & .04 & .69 \\
\hline 18 & Muddy Creek near Grantville & 6889800 & $7 / 31 / 02$ & 1000 & 72.3 & -- & -- & -- & -- & -- & -- & -- & -- & $<.01$ & .02 \\
\hline \multirow[t]{2}{*}{19} & Kansas River near Grover & 6889850 & $7 / 31 / 02$ & 900 & 68.6 & -- & -- & -- & -- & -- & -- & -- & -- & .03 & .50 \\
\hline & & & $7 / 31 / 02$ & 1400 & 68.6 & -- & -- & -- & -- & -- & -- & -- & -- & .04 & .56 \\
\hline
\end{tabular}


Appendix 1. Water-quality results from samples collected from Kansas River, northeast Kansas, selected tributaries, and selected wastewater-treatment facility effluent for synoptic surveys I, II, and III, November 2001 through August 2002.-Continued

$\left[<\right.$, less than; --, not determined; E, estimated; $>$, greater than; $\mathrm{FNU}$, formazin nephelometric units; $\mathrm{CO}_{3}$, carbonate; $\mathrm{HCO}_{3}$, bicarbonate; $\mathrm{CaCO}_{3}$, calcium carbonate; ${ }^{\circ} \mathrm{C}$, degrees $\mathrm{Cel}$ sius; $\mathrm{SO}{ }_{4}$, sulfate; $\mathrm{Cl}$, chloride; $\mathrm{N}$, nitrogen; $\mathrm{P}$, phosphorus; $\mathrm{C}$, carbon]

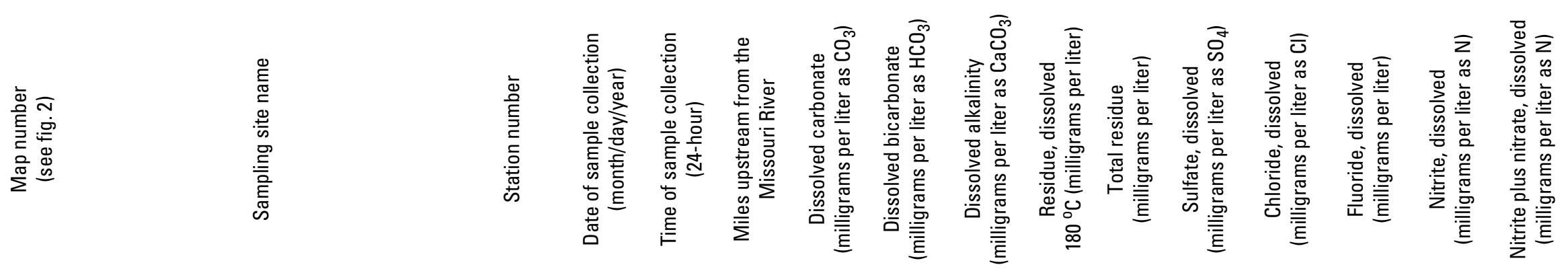

\begin{tabular}{|c|c|c|c|c|c|c|c|c|c|c|c|c|c|c|c|}
\hline \multicolumn{16}{|c|}{ Synoptic survey III-Continued } \\
\hline 20 & Delaware River below Perry Dam & 6890900 & $7 / 30 / 02$ & 1210 & 65.1 & -- & -- & -- & -- & -- & -- & -- & -- & $<0.01$ & 0.03 \\
\hline \multirow[t]{5}{*}{21} & Kansas River at Lecompton & 6891000 & $7 / 22 / 02$ & 1345 & 64.0 & -- & -- & -- & -- & -- & -- & -- & -- & $<.01$ & $<.01$ \\
\hline & & & $8 / 1 / 02$ & 950 & 64.0 & -- & -- & -- & -- & -- & -- & -- & -- & $<.01$ & $<.01$ \\
\hline & & & $8 / 1 / 02$ & 1400 & 64.0 & -- & -- & -- & -- & -- & -- & -- & -- & $<.01$ & $<.01$ \\
\hline & & & $8 / 6 / 02$ & 1430 & 64.0 & -- & -- & -- & -- & -- & -- & -- & -- & .02 & .04 \\
\hline & & & $8 / 7 / 02$ & 850 & 64.0 & -- & -- & -- & -- & -- & -- & -- & -- & .02 & .14 \\
\hline 22 & Buck Creek at Williamstown & 6891060 & $7 / 31 / 02$ & 900 & 58.6 & -- & -- & -- & -- & -- & -- & -- & -- & .04 & .62 \\
\hline 23 & Kansas River near Midland & 6891070 & $8 / 1 / 02$ & 1120 & 57.5 & -- & -- & -- & -- & -- & -- & -- & -- & $<.01$ & $<.01$ \\
\hline 24 & Kansas River at Lawrence & 6891080 & $8 / 1 / 02$ & 1220 & 51.9 & -- & -- & -- & -- & -- & -- & -- & -- & $<.01$ & $<.01$ \\
\hline 25 & Lawrence wastewater-treatment facility & 6891090 & $7 / 29 / 02$ & 1120 & 51.1 & -- & -- & -- & -- & -- & -- & -- & -- & .12 & 15 \\
\hline \multirow[t]{2}{*}{26} & Kansas River between Lawrence and & 6891093 & $8 / 1 / 02$ & 830 & 50.6 & -- & -- & -- & -- & -- & -- & -- & -- & .01 & .39 \\
\hline & Farmland facility & & $8 / 1 / 02$ & 1100 & 50.6 & -- & -- & -- & -- & -- & -- & -- & -- & .01 & .40 \\
\hline 27 & $\begin{array}{l}\text { Farmland nitrogen wastewater-treatment } \\
\text { facility, Lawrence }\end{array}$ & 6891095 & $7 / 29 / 02$ & 1225 & 50.1 & -- & -- & -- & -- & -- & -- & -- & -- & .40 & 6.0 \\
\hline 28 & Kansas River below Farmland facility & 6891096 & $8 / 1 / 02$ & 930 & 48.6 & -- & -- & -- & -- & -- & -- & -- & -- & $<.01$ & .05 \\
\hline 29 & Mud Creek near Lawrence & 6891098 & $7 / 31 / 02$ & 825 & 47.6 & -- & -- & -- & -- & -- & -- & -- & -- & $<.01$ & $<.01$ \\
\hline 30 & Kansas River at Eudora & 6891100 & $7 / 29 / 02$ & 900 & 43.4 & -- & -- & -- & -- & -- & -- & -- & -- & .01 & .19 \\
\hline 31 & Wakarusa River at 1900 Road near Eudora & 6891675 & $7 / 30 / 02$ & 820 & 42.6 & -- & -- & -- & -- & -- & -- & -- & -- & .01 & .13 \\
\hline 32 & Stranger Creek above Linwood & 6892200 & $7 / 30 / 02$ & 1245 & 35.4 & -- & -- & -- & -- & -- & -- & -- & -- & $<.01$ & $<.01$ \\
\hline
\end{tabular}


[<, less than; --, not determined; E, estimated; >, greater than; $\mathrm{FNU}$, formazin nephelometric units; $\mathrm{CO}_{3}$, carbonate; $\mathrm{HCO}_{3}$, bicarbonate; $\mathrm{CaCO} 3$, calcium carbonate; ${ }^{\circ} \mathrm{C}$, degrees $\mathrm{Celsius;} \mathrm{SO}{ }_{4}$, sulfate; $\mathrm{Cl}_{\text {, chloride; }}$ $\mathrm{N}$, nitrogen; $\mathrm{P}$, phosphorus; $\mathrm{C}$, carbon]

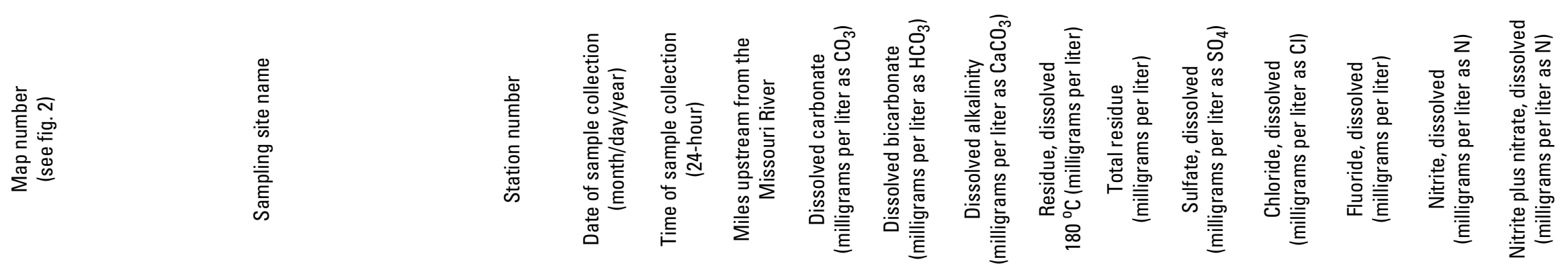

\begin{tabular}{|c|c|c|c|c|c|c|c|c|c|c|c|c|c|c|c|}
\hline \multicolumn{16}{|c|}{ Synoptic survey III-Continued } \\
\hline 33 & Kansas River at DeSoto & 6892350 & $7 / 25 / 02$ & 1130 & 31.7 & -- & -- & -- & -- & -- & -- & -- & -- & $<0.01$ & 0.01 \\
\hline & & & $7 / 29 / 02$ & 1045 & 31.7 & -- & -- & -- & -- & -- & -- & -- & -- & .01 & .07 \\
\hline & & & $7 / 29 / 02$ & 1330 & 31.7 & -- & -- & -- & -- & -- & -- & -- & -- & $<.01$ & .02 \\
\hline & & & $8 / 2 / 02$ & 700 & 31.7 & -- & -- & -- & -- & -- & -- & -- & -- & .01 & .11 \\
\hline & & & $8 / 2 / 02$ & 1300 & 31.7 & -- & -- & -- & -- & -- & -- & -- & -- & .01 & .14 \\
\hline & & & $8 / 6 / 02$ & 1300 & 31.7 & -- & -- & -- & -- & -- & -- & -- & -- & $<.01$ & $<.01$ \\
\hline & & & $8 / 7 / 02$ & 825 & 31.7 & -- & -- & -- & -- & -- & -- & -- & -- & $<.01$ & $<.01$ \\
\hline 34 & DeSoto wastewater-treatment facility & 6892358 & $7 / 29 / 02$ & 830 & 31.0 & -- & -- & -- & -- & -- & -- & -- & -- & .02 & .04 \\
\hline 35 & Kill Creek at 83rd Street & 6892360 & $7 / 30 / 02$ & 850 & 31.0 & -- & -- & -- & -- & -- & -- & -- & -- & $<.01$ & .19 \\
\hline 36 & Kansas River near Cedar & 6892380 & $7 / 30 / 02$ & 1200 & 30.8 & -- & -- & -- & -- & -- & -- & -- & -- & $<.01$ & $<.01$ \\
\hline & & & $7 / 30 / 02$ & 1330 & 30.8 & -- & -- & -- & -- & -- & -- & -- & -- & $<.01$ & $<.01$ \\
\hline 37 & Cedar Creek near Cedar Junction & 6892490 & $7 / 30 / 02$ & 920 & 26.7 & -- & -- & -- & -- & -- & -- & -- & -- & .06 & 4.4 \\
\hline 38 & Kansas River at Bonner Springs & 6892500 & $8 / 6 / 02$ & 910 & 20.7 & -- & -- & -- & -- & -- & -- & -- & -- & $<.01$ & $<.01$ \\
\hline 39 & Bonner Springs wastewater-treatment facility & 6892502 & $7 / 29 / 02$ & 1330 & 20.3 & -- & -- & -- & -- & -- & -- & -- & -- & .91 & 24 \\
\hline 40 & Kansas River near Lake of the Forest & 6892504 & $7 / 30 / 02$ & 945 & 19.4 & -- & -- & -- & -- & -- & -- & -- & -- & $<.01$ & $<.01$ \\
\hline 41 & Kansas River near Edwardsville & 6892505 & $7 / 30 / 02$ & 900 & 16.6 & -- & -- & -- & -- & -- & -- & -- & -- & $<.01$ & $<.01$ \\
\hline 42 & Mill Creek at Wilder Road & 6892515 & $7 / 30 / 02$ & 1000 & 16.1 & -- & -- & -- & -- & -- & -- & -- & -- & .02 & .61 \\
\hline 43 & Kansas River near I-435 Bridge & 6892518 & $7 / 30 / 02$ & 745 & 15.4 & -- & -- & -- & -- & -- & -- & -- & -- & $<.01$ & $<.01$ \\
\hline 44 & $\begin{array}{l}\text { Johnson County Mill Creek wastewater- } \\
\text { treatment facility }\end{array}$ & 6892520 & $7 / 29 / 02$ & 930 & 15.0 & -- & -- & -- & -- & -- & -- & -- & -- & .39 & 1.8 \\
\hline
\end{tabular}


Appendix 1. Water-quality results from samples collected from Kansas River, northeast Kansas, selected tributaries, and selected wastewater-treatment facility effluent for synoptic surveys I, II, and III, November 2001 through August 2002.-Continued

$\left[<\right.$, less than; --, not determined; E, estimated; $>$, greater than; $\mathrm{FNU}$, formazin nephelometric units; $\mathrm{CO}_{3}$, carbonate; $\mathrm{HCO}_{3}$, bicarbonate; $\mathrm{CaCO}_{3}$, calcium carbonate; ${ }^{\circ} \mathrm{C}$, degrees $\mathrm{Cel}$ sius; $\mathrm{SO}{ }_{4}$, sulfate; $\mathrm{Cl}$, chloride; $\mathrm{N}$, nitrogen; $\mathrm{P}$, phosphorus; $\mathrm{C}$, carbon]

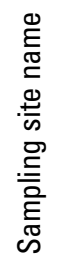

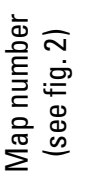

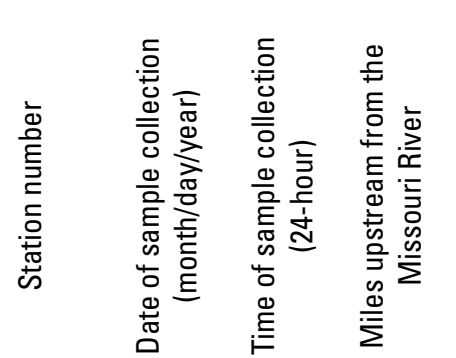

Synoptic survey III—Continued

45 Kansas City wastewater-treatment facility no. 20

46 Unnamed tributary below Kansas City wastewater treatment facility no. 14

47 Kansas River at Turner Bridge

48 Kansas River at west Kansas Avenue Bridge

49 Turkey Creek at Kansas City near I-35

$50 \quad$ Kansas River above Missouri River confluence
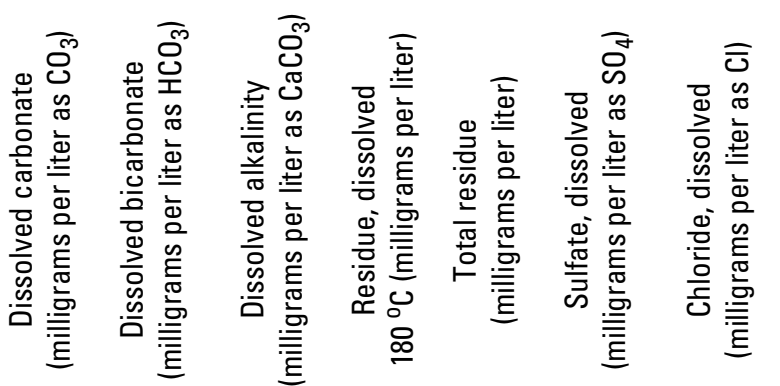
Appendix 1. Water-quality results from samples collected from Kansas River, northeast Kansas, selected tributaries, and selected wastewater-treatment facility effluent for synoptic surveys I, II, and III, November 2001 through August 2002.-Continued

$\left[<\right.$, less than; --, not determined; E, estimated; >, greater than; $\mathrm{FNU}$, formazin nephelometric units; $\mathrm{CO}_{3}$, carbonate; $\mathrm{HCO}_{3}$, bicarbonate; $\mathrm{CaCO}_{3}$, calcium carbonate; ${ }^{\circ} \mathrm{C}$, degrees $\mathrm{Celsius;} \mathrm{SO}_{4}$, sulfate; $\mathrm{Cl}$, chloride, $\mathrm{N}$, nitrogen; $\mathrm{P}$, phosphorus; $\mathrm{C}$, carbon]

\begin{tabular}{|c|c|c|c|c|c|c|c|c|c|c|c|c|c|}
\hline 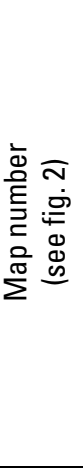 & 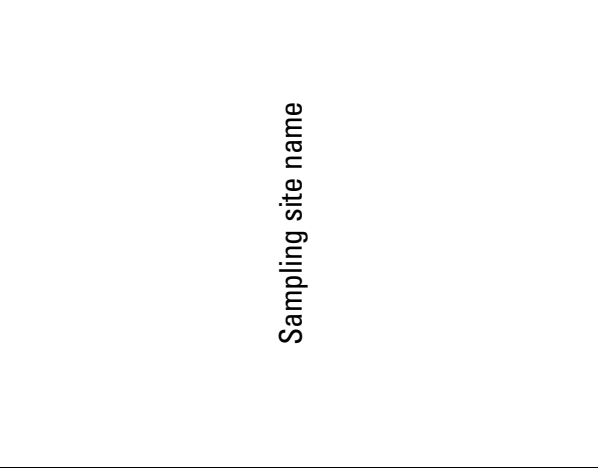 & 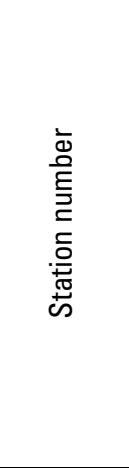 & 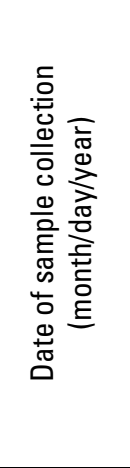 & 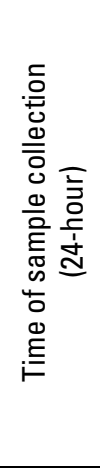 & 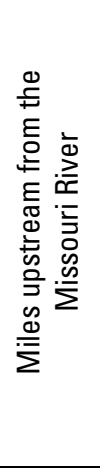 & 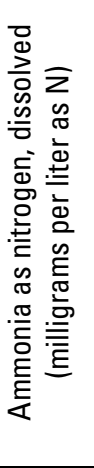 & 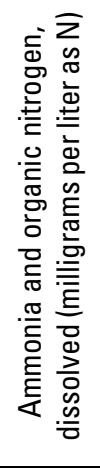 & 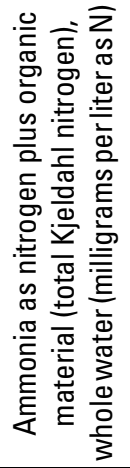 & 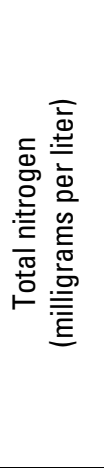 & 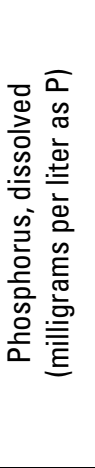 & 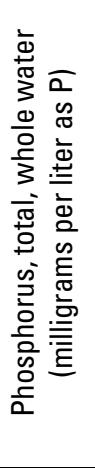 & 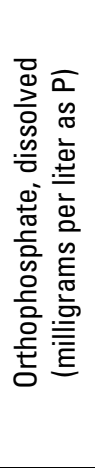 & 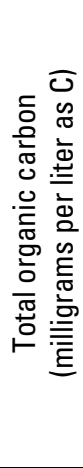 \\
\hline \multicolumn{14}{|c|}{ Synoptic survey I } \\
\hline 10 & Kansas River at Highway 75, Topeka & 6888980 & $11 / 29 / 01$ & 1100 & 86.0 & 0.02 & 0.27 & 0.51 & 1.1 & 0.15 & 0.19 & 0.13 & 7.9 \\
\hline 11 & North Topeka wastewater-treatment facility & 6888985 & $11 / 28 / 01$ & 1220 & 85.0 & 1.8 & 3.7 & 4.2 & 4.5 & 4.9 & 5.1 & .86 & 18 \\
\hline 13 & Topeka Oakland wastewater-treatment facility & 6889002 & $11 / 28 / 01$ & 1115 & 81.7 & E.72 & 15 & 18 & 18 & 1.9 & 2.0 & $<.02$ & 23 \\
\hline 15 & Soldier Creek, Meriden Road, near Topeka & 6889504 & $11 / 29 / 01$ & 930 & 80.5 & .03 & .19 & .28 & .54 & .07 & .10 & .06 & 3.1 \\
\hline 16 & Shunganunga Creek at Rice Road, Topeka & 6889700 & $11 / 29 / 01$ & 1030 & 76.0 & .02 & .29 & .48 & .73 & .14 & .17 & .12 & 8.3 \\
\hline 18 & Muddy Creek near Grantville & 6889800 & $11 / 28 / 01$ & 850 & 72.3 & .03 & .25 & .30 & .42 & .08 & .09 & .07 & 4.9 \\
\hline 20 & Delaware River below Perry Dam & 6890900 & $11 / 28 / 01$ & 920 & 65.1 & E.01 & .30 & .45 & 1.1 & .07 & .14 & .07 & 5.5 \\
\hline 21 & Kansas River at Lecompton & 6891000 & $11 / 28 / 01$ & 1330 & 64.0 & .19 & .47 & .70 & 1.4 & .19 & .22 & .17 & 5.7 \\
\hline 25 & Lawrence wastewater-treatment facility & 6891090 & $11 / 28 / 01$ & 920 & 51.1 & .37 & 1.5 & 3.1 & 15 & 5.5 & 5.9 & .40 & 18 \\
\hline 27 & $\begin{array}{l}\text { Farmland nitrogen wastewater-treatment } \\
\text { facility, Lawrence }\end{array}$ & 6891095 & $11 / 28 / 01$ & 845 & 50.1 & 3.7 & 20 & 22 & 52 & .39 & .80 & .33 & 17 \\
\hline 29 & Mud Creek near Lawrence & 6891098 & $11 / 27 / 01$ & 1145 & 47.6 & .06 & .18 & .25 & .36 & .02 & .08 & .01 & 2.5 \\
\hline 30 & Kansas River at Eudora & 6891100 & $11 / 28 / 01$ & 1030 & 43.4 & .09 & .41 & .70 & 1.6 & .21 & .26 & .20 & 5.5 \\
\hline 31 & Wakarusa River at 1900 Road near Eudora & 6891675 & $11 / 27 / 01$ & 755 & 42.6 & E.01 & .44 & .57 & .61 & .03 & .06 & .01 & 5.8 \\
\hline 32 & Stranger Creek above Linwood & 6892200 & $11 / 27 / 01$ & 1240 & 35.4 & E.01 & .21 & .42 & .53 & .05 & .10 & .04 & 4.2 \\
\hline 35 & Kill Creek at 83rd Street & 6892360 & $11 / 27 / 01$ & 1015 & 31.0 & .03 & .28 & .39 & .40 & .05 & .08 & .04 & 4.5 \\
\hline
\end{tabular}


Appendix 1. Water-quality results from samples collected from Kansas River, northeast Kansas, selected tributaries, and selected wastewater-treatment facility effluent for synoptic surveys I, II, and III, November 2001 through August 2002.-Continued

$\left[<\right.$, less than; --, not determined; E, estimated; >, greater than; $\mathrm{FNU}$, formazin nephelometric units; $\mathrm{CO}_{3}$, carbonate; $\mathrm{HCO}_{3}$, bicarbonate; $\mathrm{CaCO}_{3}$, calcium carbonate; ${ }^{\circ} \mathrm{C}$, degrees Celsius; $\mathrm{SO}_{4}$, sulfate; $\mathrm{Cl}$, chloride, N, nitrogen; $\mathrm{P}$, phosphorus; $\mathrm{C}$, carbon]

\begin{tabular}{|c|c|c|c|c|c|c|c|c|c|c|c|c|c|}
\hline 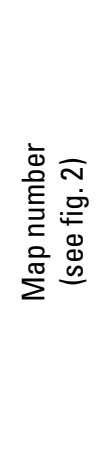 & 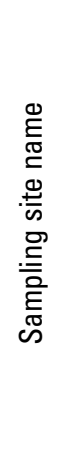 & 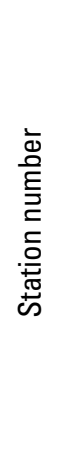 & 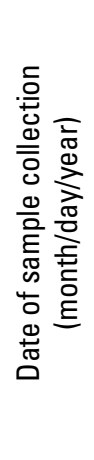 & 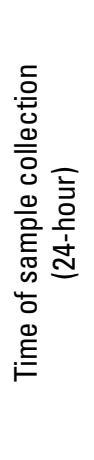 & 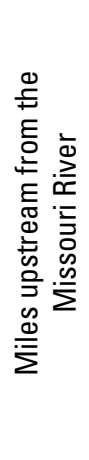 & 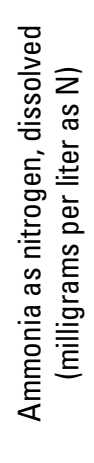 & 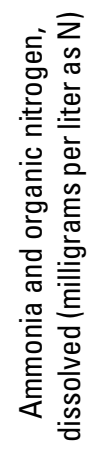 & 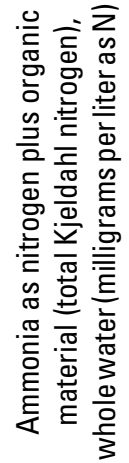 & 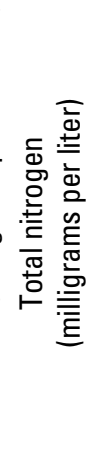 & 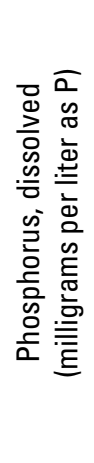 & 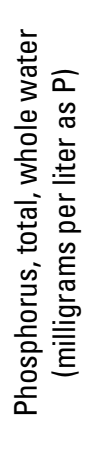 & 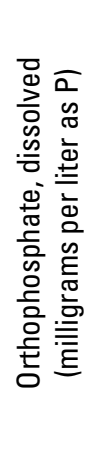 & 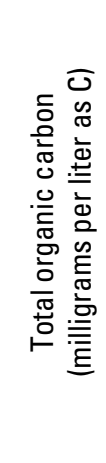 \\
\hline
\end{tabular}

\begin{tabular}{ll}
\hline 37 & Cedar Creek near Cedar Junction \\
39 & Bonner Springs wastewater-treatment \\
42 & Mill Creek at Wilder Road \\
44 & Johnson County Mill Creek wastew \\
& treatment facility \\
45 & Kansas City wastewater-treatment \\
& no. 20 \\
& \\
46 & Unnamed tributary below Kansas \\
& wastewater-treatment facility no. \\
48 & Kansas River at west Kansas Aven \\
49 & Turkey Creek at Kansas City near \\
50 & Kansas River above Missouri Rive \\
& confluence \\
& \\
2 & Vermillion Creek near Wamego \\
3 & Rock Creek near Louisville \\
4 & Kansas River at Belvue \\
5 & Kansas River near Maple Hill \\
6 & Mill Creek near Maple Hill \\
&
\end{tabular}

Synoptic survey I-Continued

$\begin{array}{cllllllllllll}6892490 & 11 / 27 / 01 & 830 & 26.7 & 0.05 & 0.60 & 0.67 & 6.5 & 1.0 & 1.2 & 0.94 & 5.4 \\ 6892502 & 11 / 29 / 01 & 1010 & 20.3 & .05 & .58 & 1.6 & 1.9 & .54 & .78 & .53 & 10 \\ 6892515 & 11 / 27 / 01 & 845 & 16.1 & .07 & .47 & .72 & 3.6 & .50 & .57 & .51 & 6.4 \\ 6892520 & 11 / 27 / 01 & 1215 & 15.0 & 19 & 20 & 21 & 25 & 3.6 & 4.0 & 3.4 & 17 \\ 6892525 & 11 / 27 / 01 & 930 & 14.8 & 1.9 & 2.8 & 3.4 & 12 & 1.9 & 2.2 & 1.8 & 10 \\ & & & & & & & & & & & \\ 6892527 & 11 / 27 / 01 & 1100 & 11.2 & .16 & .48 & 2.4 & 6.3 & .30 & 1.1 & .31 & 25 \\ 6892540 & 11 / 28 / 01 & 1010 & 6.0 & .09 & .41 & .67 & 1.5 & .19 & .27 & .17 & 6.2 \\ 6892942 & 11 / 27 / 01 & 1030 & 3.2 & 3.9 & 6.4 & 7.5 & 15 & 2.9 & 3.3 & 2.6 & 26 \\ 6892960 & 11 / 27 / 01 & 1230 & 1.1 & .12 & .41 & .95 & 1.8 & .19 & .28 & .17 & 7.4\end{array}$

Synoptic survey II

$\begin{array}{rrrrrrrrrrrr}6888000 & 2 / 28 / 02 & 1310 & 119.2 & \text { E.01 } & .20 & .34 & .50 & .01 & .04 & <.01 & 3.4 \\ 6888300 & 2 / 28 / 02 & 1215 & 118.2 & .02 & .16 & .28 & .42 & .03 & .06 & .02 & 2.9 \\ 6888350 & 2 / 28 / 02 & 1315 & 113.0 & .02 & .36 & .69 & 1.4 & .14 & .20 & .12 & 6.5 \\ 6888400 & 2 / 28 / 02 & 1135 & 103.7 & .02 & .36 & .81 & 1.5 & .13 & .22 & .11 & 7.3 \\ 6888650 & 2 / 28 / 02 & 1015 & 101.7 & .02 & .13 & .40 & .41 & .01 & .04 & <.01 & 2.6 \\ 6888700 & 2 / 28 / 02 & 1400 & 100.1 & .02 & .24 & .35 & .68 & .05 & .07 & .03 & 3.1\end{array}$


Appendix 1. Water-quality results from samples collected from Kansas River, northeast Kansas, selected tributaries, and selected wastewater-treatment facility effluent for synoptic surveys I, II, and III, November 2001 through August 2002.-Continued

$\left[<\right.$, less than; --, not determined; E, estimated; $>$, greater than; $\mathrm{FNU}$, formazin nephelometric units; $\mathrm{CO}_{3}$, carbonate; $\mathrm{HCO}_{3}$, bicarbonate; $\mathrm{CaCO}_{3}$, calcium carbonate; ${ }^{\circ} \mathrm{C}$, degrees $\mathrm{Celsius;} \mathrm{SO}_{4}$, sulfate; $\mathrm{Cl}$, chloride, N, nitrogen; $\mathrm{P}$, phosphorus; $\mathrm{C}$, carbon]

\begin{tabular}{|c|c|c|c|c|c|c|c|c|c|c|c|c|c|}
\hline 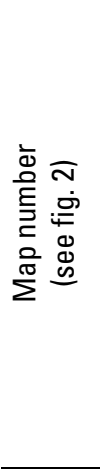 & 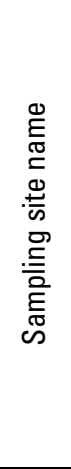 & 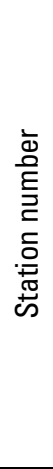 & 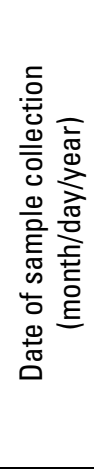 & 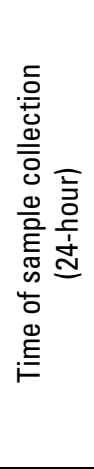 & 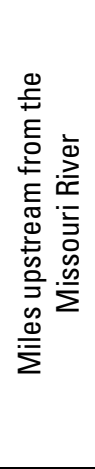 & 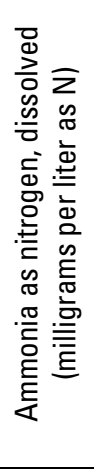 & 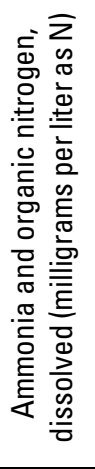 & 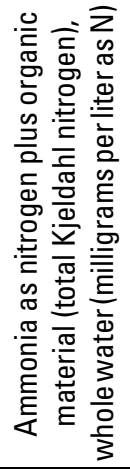 & 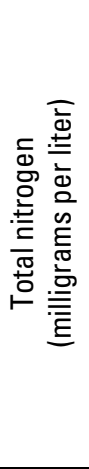 & 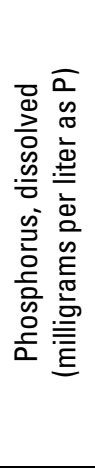 & 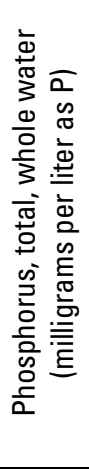 & 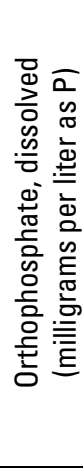 & 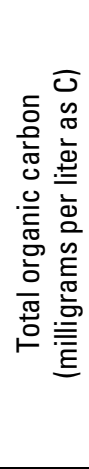 \\
\hline
\end{tabular}

\begin{tabular}{|c|c|c|c|c|c|c|c|c|c|c|c|c|c|}
\hline \multicolumn{14}{|c|}{ Synoptic survey II-Continued } \\
\hline 8 & Kansas River at Willard & 6888705 & $2 / 28 / 02$ & 950 & 98.9 & 0.02 & 0.33 & 0.85 & 1.5 & 0.13 & 0.20 & 0.11 & 7.2 \\
\hline 9 & Mission Creek near Valencia & 6888800 & $2 / 28 / 02$ & 900 & 91.6 & .01 & .16 & .25 & .37 & .01 & .02 & $<.01$ & 2.8 \\
\hline 10 & Kansas River at Highway 75 , Topeka & 6888980 & $2 / 28 / 02$ & 1115 & 86.0 & .02 & .34 & 1.0 & 1.5 & .11 & .20 & .09 & 7.3 \\
\hline 11 & North Topeka wastewater-treatment facility & 6888985 & $2 / 26 / 02$ & 1130 & 85.0 & .13 & 2.2 & 2.6 & 12 & 3.2 & 3.8 & 3.4 & 18 \\
\hline 12 & Kansas River at Topeka & 6889000 & $2 / 27 / 02$ & 1320 & 83.0 & .02 & .30 & .88 & 1.4 & .10 & -- & .11 & 7.2 \\
\hline 13 & Topeka Oakland wastewater-treatment facility & 6889002 & $2 / 26 / 02$ & 1045 & 81.7 & 30 & 34 & 34 & 34 & 2.5 & 3.0 & 2.4 & 20 \\
\hline 14 & Kansas River at Highway 4, Topeka & 6889010 & $2 / 28 / 02$ & 855 & 81.1 & .16 & .50 & 1.0 & 1.6 & .15 & .23 & .13 & 7.1 \\
\hline 15 & Soldier Creek, Meriden Road, near Topeka & 6889504 & $2 / 27 / 02$ & 1215 & 80.5 & .03 & .24 & .40 & .68 & .08 & .15 & .06 & 3.7 \\
\hline 16 & Shunganunga Creek at Rice Road, Topeka & 6889700 & $2 / 27 / 02$ & 1315 & 76.0 & .03 & .36 & .53 & .76 & .14 & .20 & .12 & 6.0 \\
\hline 17 & Kansas River near Grantville & 6889750 & $2 / 28 / 02$ & 1100 & 73.7 & .12 & .46 & 1.1 & 1.6 & .15 & .24 & .12 & 7.3 \\
\hline 18 & Muddy Creek near Grantville & 6889800 & $2 / 27 / 02$ & 900 & 72.3 & .04 & .20 & .27 & .43 & .05 & .07 & .04 & 3.2 \\
\hline 19 & Kansas River near Grover & 6889850 & $2 / 28 / 02$ & 1330 & 68.6 & .12 & .43 & 1.1 & 1.6 & .14 & .23 & .12 & 7.6 \\
\hline 20 & Delaware River below Perry Dam & 6890900 & $2 / 27 / 02$ & 930 & 65.1 & $<.02$ & .27 & .59 & .91 & .03 & .08 & .02 & 5.7 \\
\hline 21 & Kansas River at Lecompton & 6891000 & $2 / 27 / 02$ & 1025 & 64.0 & .16 & .46 & 1.1 & 1.4 & .09 & -- & .09 & 7.3 \\
\hline 22 & Buck Creek at Williamstown & 6891060 & $2 / 27 / 02$ & 1015 & 58.6 & .02 & .18 & .24 & .85 & .01 & .02 & $<.01$ & 3.0 \\
\hline 23 & Kansas River near Midland & 6891070 & $3 / 1 / 02$ & 935 & 57.5 & .05 & .32 & .98 & 1.5 & .11 & .23 & .09 & 7.1 \\
\hline 24 & Kansas River at Lawrence & 6891080 & $2 / 27 / 02$ & 1020 & 51.9 & .02 & .32 & 1.2 & 1.4 & .07 & -- & .05 & 8.4 \\
\hline 25 & Lawrence wastewater-treatment facility & 6891090 & $2 / 25 / 02$ & 1305 & 51.1 & 8.8 & 10 & 12 & 20 & 3.0 & 3.7 & 3.0 & 17 \\
\hline
\end{tabular}


Appendix 1. Water-quality results from samples collected from Kansas River, northeast Kansas, selected tributaries, and selected wastewater-treatment facility effluent for synoptic surveys I, II, and III, November 2001 through August 2002.-Continued

$\left[<\right.$, less than; --, not determined; E, estimated; >, greater than; $\mathrm{FNU}$, formazin nephelometric units; $\mathrm{CO}_{3}$, carbonate; $\mathrm{HCO}_{3}$, bicarbonate; $\mathrm{CaCO}_{3}$, calcium carbonate; ${ }^{\circ} \mathrm{C}$, degrees Celsius; $\mathrm{SO}_{4}$, sulfate; $\mathrm{Cl}$, chloride, $\mathrm{N}$, nitrogen; $\mathrm{P}$, phosphorus; $\mathrm{C}$, carbon]

\begin{tabular}{|c|c|c|c|c|c|c|c|c|c|c|c|c|c|}
\hline 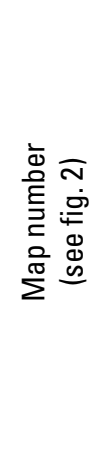 & 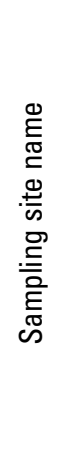 & 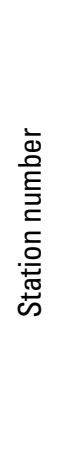 & 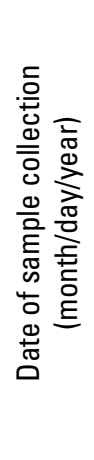 & 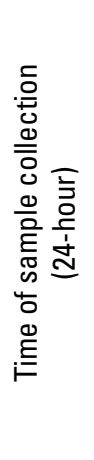 & 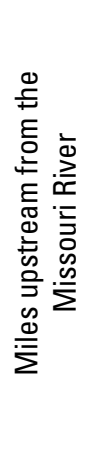 & 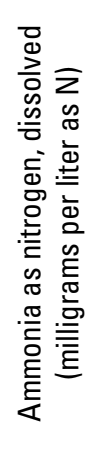 & 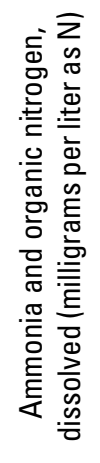 & 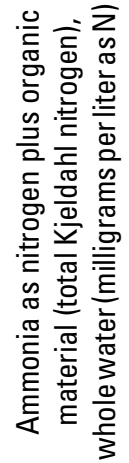 & 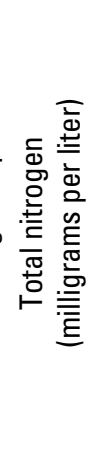 & 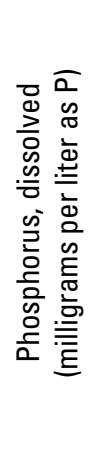 & 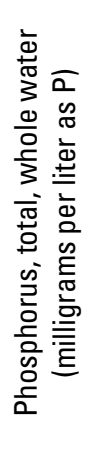 & 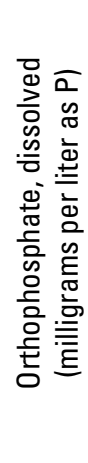 & 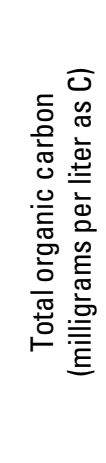 \\
\hline
\end{tabular}

\begin{tabular}{|c|c|c|c|c|c|c|c|c|c|c|c|c|c|}
\hline \multicolumn{14}{|c|}{ Synoptic survey II-Continued } \\
\hline 26 & $\begin{array}{l}\text { Kansas River between Lawrence and } \\
\text { Farmland facility }\end{array}$ & 6891093 & $2 / 27 / 02$ & 1115 & 50.6 & 0.06 & 0.36 & 1.20 & 1.4 & 0.07 & -- & 0.07 & 7.9 \\
\hline 27 & $\begin{array}{l}\text { Farmland nitrogen wastewater-treatment } \\
\text { facility, Lawrence }\end{array}$ & 6891095 & $2 / 26 / 02$ & 840 & 50.1 & 10 & 10 & 16 & 57 & .06 & 0.68 & E.02 & 15 \\
\hline 28 & Kansas River below Farmland facility & 6891096 & $2 / 27 / 02$ & 1300 & 48.6 & .04 & .34 & 1.2 & 1.5 & .06 & -- & .07 & 8.3 \\
\hline 29 & Mud Creek near Lawrence & 6891098 & $2 / 26 / 02$ & 1045 & 47.6 & .03 & .25 & .41 & .45 & .01 & .10 & E.01 & 3.8 \\
\hline 30 & Kansas River at Eudora & 6891100 & $2 / 25 / 02$ & 930 & 43.4 & .03 & .34 & 1.5 & 1.6 & .12 & .33 & .07 & 11 \\
\hline 31 & Wakarusa River at 1900 Road near Eudora & 6891675 & $2 / 26 / 02$ & 900 & 42.6 & .02 & .34 & .44 & .47 & .01 & .06 & E.01 & 5.9 \\
\hline 32 & Stranger Creek above Linwood & 6892200 & $2 / 26 / 02$ & 1145 & 35.4 & .11 & .43 & .52 & 1.4 & .05 & .11 & .04 & 4.5 \\
\hline 33 & Kansas River at DeSoto & 6892350 & $2 / 25 / 02$ & 1230 & 31.7 & .03 & .29 & 1.3 & 1.4 & .07 & .25 & .06 & 9.7 \\
\hline 34 & DeSoto wastewater-treatment facility & 6892358 & $2 / 25 / 02$ & 830 & 31.0 & .10 & 1.0 & 1.6 & 2.6 & 2.3 & 2.7 & 2.2 & 8.6 \\
\hline 35 & Kill Creek at 83rd Street & 6892360 & $2 / 25 / 02$ & 915 & 31.0 & .06 & .37 & .53 & .72 & .03 & .08 & .02 & 7.0 \\
\hline 36 & Kansas River near Cedar & 6892380 & $2 / 26 / 02$ & 1230 & 30.8 & .02 & .30 & 1.2 & 1.2 & .06 & .27 & .05 & 8.9 \\
\hline 37 & Cedar Creek near Cedar Junction & 6892490 & $2 / 25 / 02$ & 1315 & 26.7 & $<.03$ & .31 & .70 & 2.1 & .24 & .29 & .24 & 4.6 \\
\hline 38 & Kansas River at Bonner Springs & 6892500 & $2 / 26 / 02$ & 1030 & 20.7 & .02 & .35 & 1.4 & 1.4 & .03 & .28 & .02 & 9.3 \\
\hline 39 & Bonner Springs wastewater-treatment facility & 6892502 & $2 / 26 / 02$ & 945 & 20.3 & .06 & .84 & .93 & 6.6 & .04 & .09 & .01 & 6.9 \\
\hline 40 & Kansas River near Lake of the Forest & 6892504 & $2 / 26 / 02$ & 1005 & 19.4 & .02 & .32 & 1.5 & 1.5 & .04 & .32 & .03 & 11 \\
\hline 41 & Kansas River near Edwardsville & 6892505 & $2 / 26 / 02$ & 1130 & 16.6 & .02 & .28 & 1.7 & 1.7 & .04 & .33 & .02 & 9.8 \\
\hline
\end{tabular}


Appendix 1. Water-quality results from samples collected from Kansas River, northeast Kansas, selected tributaries, and selected wastewater-treatment facility effluent for synoptic surveys I, II, and III, November 2001 through August 2002.-Continued

$\left[<\right.$, less than; --, not determined; E, estimated; >, greater than; $\mathrm{FNU}$, formazin nephelometric units; $\mathrm{CO}_{3}$, carbonate; $\mathrm{HCO}_{3}$, bicarbonate; $\mathrm{CaCO}_{3}$, calcium carbonate; ${ }^{\circ} \mathrm{C}$, degrees Celsius; $\mathrm{SO}_{4}$, sulfate; $\mathrm{Cl}$, chloride, N, nitrogen; P, phosphorus; C, carbon]

\begin{tabular}{|c|c|c|c|c|c|c|c|c|c|c|c|c|c|}
\hline 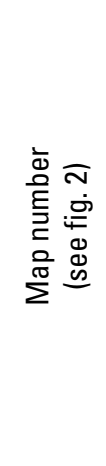 & 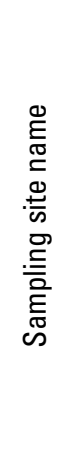 & 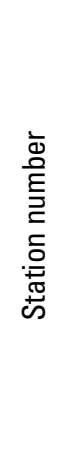 & 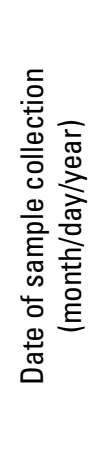 & 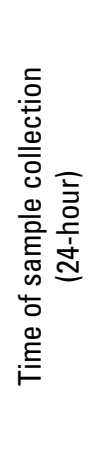 & 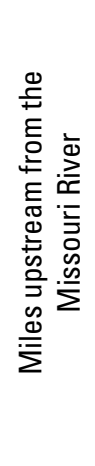 & 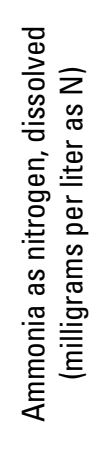 & 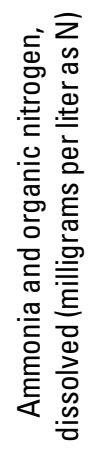 & 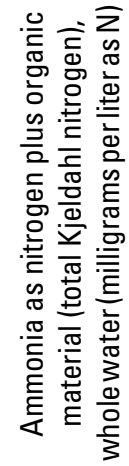 & 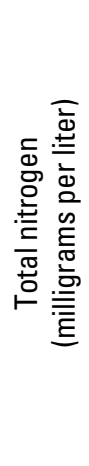 & 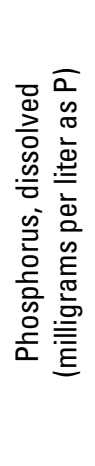 & 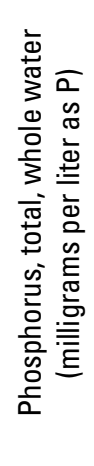 & 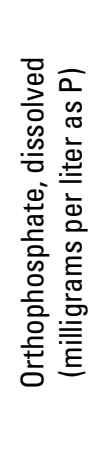 & 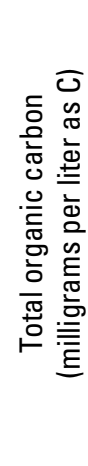 \\
\hline
\end{tabular}

\begin{tabular}{ll}
\hline 42 & Mill Creek at Wilder Road \\
43 & Kansas River near I-435 Bridge \\
44 & Johnson County Mill Creek wastewater- \\
treatment facility \\
45 & Kansas City wastewater-treatment facility \\
& no. 20 \\
46 & Unnamed tributary below Kansas City \\
& wastewater treatment facility no. 14 \\
& \\
47 & Kansas River at Turner Bridge \\
48 & Kansas River at west Kansas Avenue Bridge \\
49 & Turkey Creek at Kansas City near I-35 \\
50 & Kansas River above Missouri River \\
& confluence \\
& \\
1 & Kansas River at Wamego \\
2 & Vermillion Creek near Wamego \\
3 & Rock Creek near Louisville \\
4 & Kansas River at Belvue \\
5 & Kansas River near Maple Hill \\
& \\
6 & Mill Creek near Maple Hill \\
&
\end{tabular}

Synoptic survey II-Continued

\begin{tabular}{|c|c|c|c|c|c|c|c|c|c|c|c|}
\hline 6892515 & $2 / 25 / 02$ & 1015 & 16.1 & 0.04 & 0.33 & 0.47 & 1.5 & 0.19 & 0.26 & 0.19 & 4.6 \\
\hline 6892518 & $2 / 26 / 02$ & 925 & 15.4 & .02 & .34 & 1.2 & 1.2 & .03 & .26 & .01 & 9.7 \\
\hline 6892520 & $2 / 25 / 02$ & 1150 & 15.0 & 3.5 & 19 & 23 & 23 & 3.0 & 3.7 & 2.6 & 21 \\
\hline 6892525 & $2 / 25 / 02$ & 1000 & 14.8 & .31 & 1.4 & 1.7 & 12 & 2.0 & 2.2 & 1.9 & 8.4 \\
\hline 6892527 & $2 / 25 / 02$ & 1030 & 11.2 & .06 & .17 & .23 & .55 & .03 & .04 & .02 & 2.5 \\
\hline 6892530 & $2 / 25 / 02$ & 1235 & 9.7 & .03 & .30 & 1.7 & 1.9 & .06 & .32 & .04 & 8.1 \\
\hline 6892540 & $2 / 25 / 02$ & 1050 & 6.0 & .03 & .32 & 1.5 & 1.7 & .06 & .31 & .03 & 9.9 \\
\hline 6892942 & $2 / 25 / 02$ & 1120 & 3.2 & 3.3 & 5.3 & 6.0 & 13 & 2.0 & 2.6 & 2.8 & 22 \\
\hline 6892960 & $2 / 25 / 02$ & 745 & 1.1 & .02 & .35 & 1.4 & 1.8 & .09 & .35 & .07 & 9.6 \\
\hline \multicolumn{12}{|c|}{ Synoptic survey III } \\
\hline 6887500 & $7 / 31 / 02$ & 1005 & 124.0 & .02 & .33 & 1.6 & 1.6 & .09 & .33 & .08 & 13 \\
\hline 6888000 & $8 / 1 / 02$ & 1020 & 119.2 & $<.02$ & .31 & .90 & .91 & .01 & .10 & $<.01$ & 6.4 \\
\hline 6888300 & $8 / 1 / 02$ & 945 & 118.2 & $<.02$ & .29 & .44 & .45 & .10 & .14 & .08 & 4.3 \\
\hline 6888350 & $7 / 31 / 02$ & 1205 & 113.0 & $<.02$ & .36 & 1.4 & 1.4 & .02 & .28 & .01 & 15 \\
\hline 6888400 & $7 / 31 / 02$ & 750 & 103.7 & E.01 & .32 & 1.1 & 1.1 & .09 & .27 & .08 & 12 \\
\hline
\end{tabular}


Appendix 1. Water-quality results from samples collected from Kansas River, northeast Kansas, selected tributaries, and selected wastewater-treatment facility effluent for synoptic surveys I, II, and III, November 2001 through August 2002.-Continued

$\left[<\right.$, less than; --, not determined; E, estimated; >, greater than; $\mathrm{FNU}$, formazin nephelometric units; $\mathrm{CO}_{3}$, carbonate; $\mathrm{HCO}_{3}$, bicarbonate; $\mathrm{CaCO}_{3}$, calcium carbonate; ${ }^{\circ} \mathrm{C}$, degrees Celsius; $\mathrm{SO}_{4}$, sulfate; $\mathrm{Cl}$, chloride, N, nitrogen; $\mathrm{P}$, phosphorus; $\mathrm{C}$, carbon]

\begin{tabular}{|c|c|c|c|c|c|c|c|c|c|c|c|c|c|}
\hline 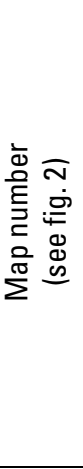 & 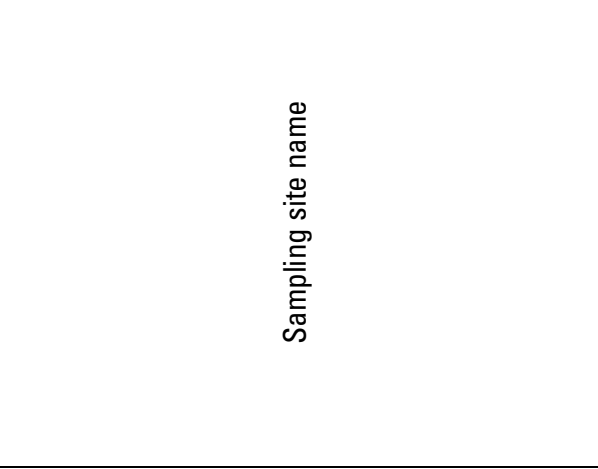 & 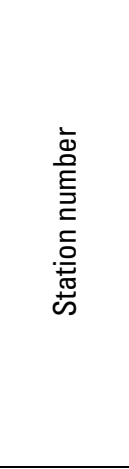 & 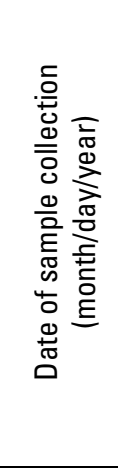 & 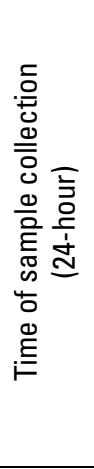 & 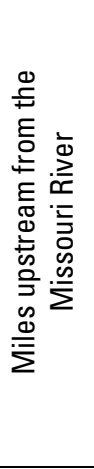 & 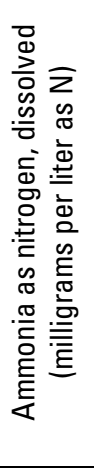 & 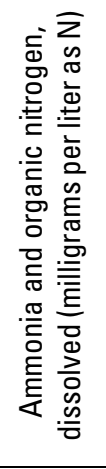 & 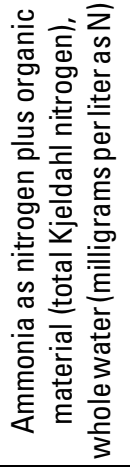 & 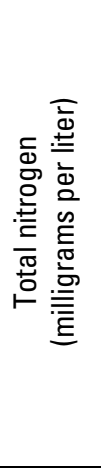 & 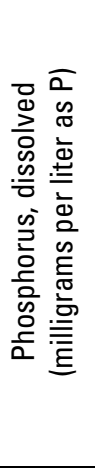 & 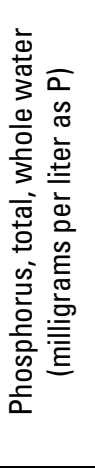 & 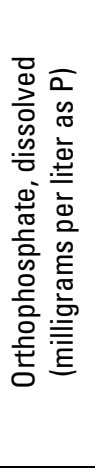 & 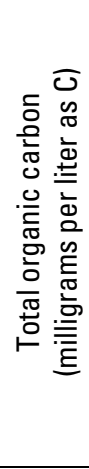 \\
\hline \multicolumn{14}{|c|}{ Synoptic survey III-Continued } \\
\hline 7 & Cross Creek near Rossville & 6888700 & $7 / 31 / 02$ & 1155 & 100.1 & 0.07 & 0.48 & 0.74 & 0.79 & 0.07 & 0.14 & 0.05 & 6.7 \\
\hline 8 & Kansas River at Willard & 6888705 & $7 / 31 / 02$ & 1020 & 98.9 & E.01 & .39 & 1.2 & 1.2 & .11 & .27 & .09 & 11 \\
\hline 9 & Mission Creek near Valencia & 6888800 & $8 / 1 / 02$ & 1210 & 91.6 & .02 & .30 & .44 & .45 & .02 & .05 & .01 & 4.7 \\
\hline 10 & Kansas River at Highway 75, Topeka & 6888980 & $7 / 31 / 02$ & 1220 & 86.0 & E.01 & .34 & 1.2 & 1.2 & .09 & .27 & .08 & 12 \\
\hline 11 & North Topeka wastewater-treatment facility & 6888985 & $7 / 30 / 02$ & 845 & 85.0 & .12 & 1.6 & 1.9 & 26 & 4.5 & 4.4 & 4.1 & 12 \\
\hline \multirow[t]{5}{*}{12} & Kansas River at Topeka & 6889000 & $7 / 23 / 02$ & 1005 & 83.0 & E.01 & .36 & 1.3 & 1.3 & .03 & .21 & .01 & 10 \\
\hline & & & $8 / 2 / 02$ & 855 & 83.0 & $<.02$ & .37 & 1.4 & 1.4 & .08 & .26 & .06 & 11 \\
\hline & & & $8 / 2 / 02$ & 1500 & 83.0 & $<.02$ & .41 & 1.6 & 1.8 & .11 & .31 & .09 & 11 \\
\hline & & & $8 / 5 / 02$ & 1515 & 83.0 & $<.02$ & .38 & 1.4 & 1.5 & .11 & .30 & .09 & 14 \\
\hline & & & $8 / 6 / 02$ & 900 & 83.0 & $<.02$ & .40 & 1.2 & 1.3 & .12 & .23 & .09 & 9.6 \\
\hline 13 & Topeka Oakland wastewater-treatment facility & 6889002 & $7 / 30 / 02$ & 815 & 81.7 & 21 & 25 & 27 & 27 & 3.3 & 3.6 & 3.1 & 22 \\
\hline \multirow[t]{2}{*}{14} & Kansas River at Highway 4, Topeka & 6889010 & $7 / 31 / 02$ & 1340 & 81.1 & .27 & .62 & 1.8 & 2.0 & .15 & .32 & .13 & 13 \\
\hline & & & $8 / 1 / 02$ & 735 & 81.1 & .04 & .44 & 1.4 & 1.7 & .15 & .31 & .12 & 8.5 \\
\hline 15 & Soldier Creek, Meriden Road, near Topeka & 6889504 & $7 / 31 / 02$ & 1300 & 80.5 & .04 & .39 & .77 & .82 & .23 & .33 & .20 & 7.3 \\
\hline 16 & Shunganunga Creek at Rice Road, Topeka & 6889700 & $7 / 31 / 02$ & 1040 & 76.0 & $<.02$ & .46 & 1.1 & 1.3 & .12 & .26 & .10 & 12 \\
\hline 17 & Kansas River near Grantville & 6889750 & $7 / 31 / 02$ & 1100 & 73.7 & .09 & .48 & 1.2 & 1.9 & .15 & .27 & .13 & 9.2 \\
\hline 18 & Muddy Creek near Grantville & 6889800 & $7 / 31 / 02$ & 1000 & 72.3 & .03 & .36 & .54 & .56 & .05 & .09 & .03 & 6.3 \\
\hline \multirow[t]{2}{*}{19} & Kansas River near Grover & 6889850 & $7 / 31 / 02$ & 900 & 68.6 & .03 & .42 & 1.2 & 1.7 & .11 & .25 & .09 & 9.3 \\
\hline & & & $7 / 31 / 02$ & 1400 & 68.6 & $<.02$ & .37 & 1.1 & 1.7 & .12 & .26 & .10 & 9.9 \\
\hline
\end{tabular}


Appendix 1. Water-quality results from samples collected from Kansas River, northeast Kansas, selected tributaries, and selected wastewater-treatment facility effluent for synoptic surveys I, II, and III, November 2001 through August 2002.-Continued

$\left[<\right.$, less than; --, not determined; E, estimated; >, greater than; $\mathrm{FNU}$, formazin nephelometric units; $\mathrm{CO}_{3}$, carbonate; $\mathrm{HCO}_{3}$, bicarbonate; $\mathrm{CaCO}_{3}$, calcium carbonate; ${ }^{\circ} \mathrm{C}$, degrees $\mathrm{Celsius;} \mathrm{SO}_{4}$, sulfate; $\mathrm{Cl}$, chloride, N, nitrogen; $\mathrm{P}$, phosphorus; $\mathrm{C}$, carbon]

\begin{tabular}{|c|c|c|c|c|c|c|c|c|c|c|c|c|c|}
\hline 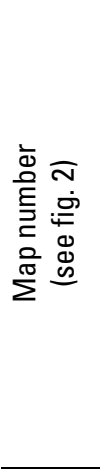 & 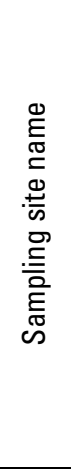 & 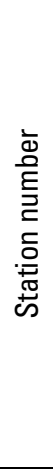 & 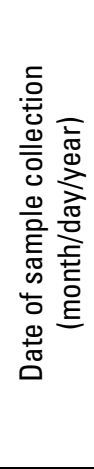 & 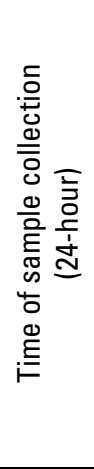 & 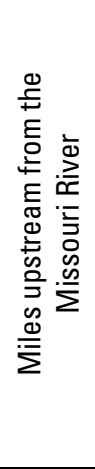 & 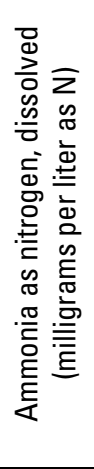 & 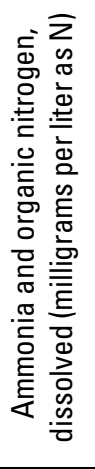 & 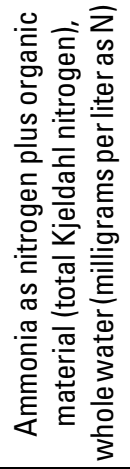 & 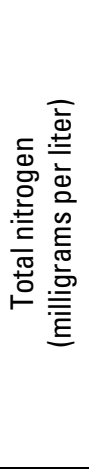 & 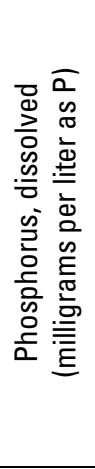 & 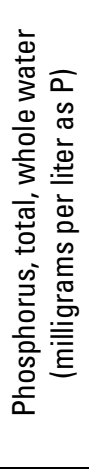 & 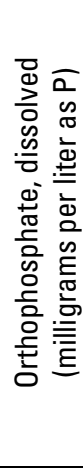 & 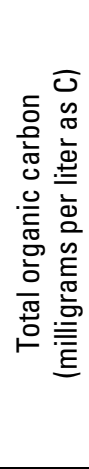 \\
\hline
\end{tabular}

\begin{tabular}{ll}
\hline 20 & Delaware River below Perry Dam \\
21 & Kansas River at Lecompton \\
& \\
& \\
& \\
22 & Buck Creek at Williamstown \\
23 & Kansas River near Midland \\
24 & Kansas River at Lawrence \\
& \\
25 & Lawrence wastewater-treatment facility \\
26 & Kansas River between Lawrence and \\
& Farmland facility \\
27 & Farmland nitrogen wastewater-treatment \\
& facility, Lawrence \\
28 & Kansas River below Farmland facility \\
29 & Mud Creek near Lawrence \\
& \\
30 & Kansas River at Eudora \\
31 & Wakarusa River at 1900 Road near Eudora \\
32 & Stranger Creek above Linwood \\
&
\end{tabular}

Synoptic survey III-Continued

$\begin{array}{clllllllllll}6890900 & 7 / 30 / 02 & 1210 & 65.1 & 0.74 & 1.1 & 1.8 & 1.9 & 0.17 & 0.47 & 0.15 & 7.7 \\ 6891000 & 7 / 22 / 02 & 1345 & 64.0 & <.02 & .37 & 1.5 & 1.5 & .03 & .23 & .01 & 12 \\ & 8 / 1 / 02 & 950 & 64.0 & <.02 & .38 & 1.5 & 1.5 & .06 & .26 & .04 & 12 \\ & 8 / 1 / 02 & 1400 & 64.0 & <.02 & .40 & 1.5 & 1.5 & .04 & .27 & .02 & 13 \\ & 8 / 6 / 02 & 1430 & 64.0 & .02 & .39 & 1.5 & 1.5 & .10 & .26 & .08 & 12 \\ & 8 / 7 / 02 & 850 & 64.0 & .12 & .54 & 1.5 & 1.6 & .11 & .25 & .09 & 9.7 \\ 6891060 & 7 / 31 / 02 & 900 & 58.6 & E .01 & .36 & .49 & 1.1 & .02 & .08 & .01 & 4.9 \\ 6891070 & 8 / 1 / 02 & 1120 & 57.5 & <.02 & .35 & 1.5 & 1.5 & .05 & .24 & .03 & 9.5 \\ 6891080 & 8 / 1 / 02 & 1220 & 51.9 & <.02 & .37 & 1.4 & 1.5 & .04 & .21 & .02 & 10 \\ & & & & & & & & & & & \\ 6891090 & 7 / 29 / 02 & 1120 & 51.1 & .20 & 1.4 & 1.7 & 17 & 3.8 & 3.9 & 3.4 & 10 \\ 6891093 & 8 / 1 / 02 & 830 & 50.6 & <.02 & .42 & 1.3 & 1.7 & .15 & .30 & .12 & 9.1 \\ & 8 / 1 / 02 & 1100 & 50.6 & <.02 & .43 & 1.4 & 1.8 & .15 & .29 & .12 & 9.0 \\ 6891095 & 7 / 29 / 02 & 1225 & 50.1 & .23 & 1.9 & 3.1 & 9.1 & .13 & .39 & .06 & 21 \\ & & & & & & & & & & & \\ 6891096 & 8 / 1 / 02 & 930 & 48.6 & <.02 & .41 & 1.3 & 1.4 & .23 & .40 & .21 & 9.2 \\ 6891098 & 7 / 31 / 02 & 825 & 47.6 & .02 & .27 & .51 & .52 & .04 & .11 & .03 & 4.3 \\ & & & & & & & & & & & \\ 6891100 & 7 / 29 / 02 & 900 & 43.4 & .07 & .53 & 1.2 & 1.4 & .15 & .27 & .12 & 9.9 \\ 6891675 & 7 / 30 / 02 & 820 & 42.6 & .03 & .33 & .69 & .81 & .04 & .15 & .03 & 6.8 \\ 6892200 & 7 / 30 / 02 & 1245 & 35.4 & E .01 & .32 & .71 & .72 & .03 & .11 & .02 & 7.2\end{array}$


Appendix 1. Water-quality results from samples collected from Kansas River, northeast Kansas, selected tributaries, and selected wastewater-treatment facility effluent for synoptic surveys I, II, and III, November 2001 through August 2002.-Continued

$\left[<\right.$, less than; --, not determined; E, estimated; >, greater than; $\mathrm{FNU}$, formazin nephelometric units; $\mathrm{CO}_{3}$, carbonate; $\mathrm{HCO}_{3}$, bicarbonate; $\mathrm{CaCO}_{3}$, calcium carbonate; ${ }^{\circ} \mathrm{C}$, degrees Celsius; $\mathrm{SO}_{4}$, sulfate; $\mathrm{Cl}$, chloride, $\mathrm{N}$, nitrogen; $\mathrm{P}$, phosphorus; $\mathrm{C}$, carbon]

\begin{tabular}{|c|c|c|c|c|c|c|c|c|c|c|c|c|c|}
\hline 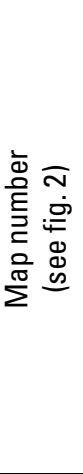 & 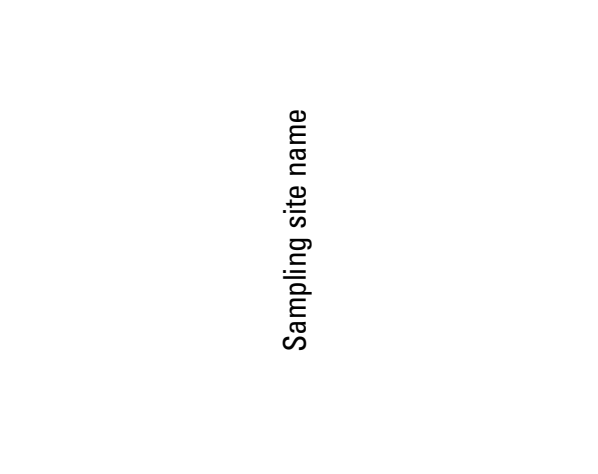 & 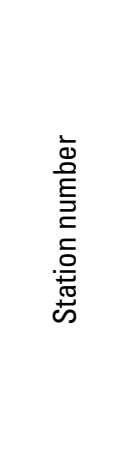 & 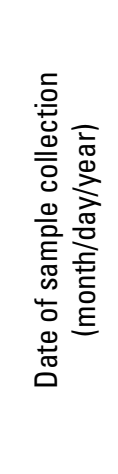 & 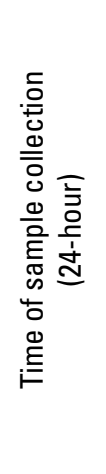 & 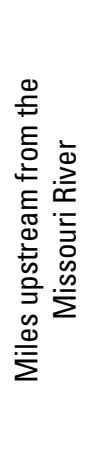 & 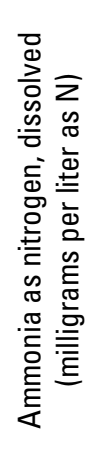 & 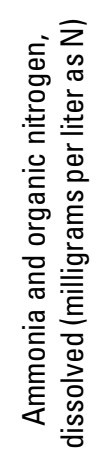 & 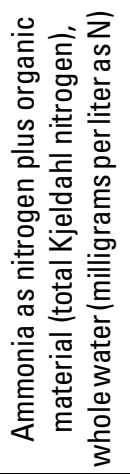 & 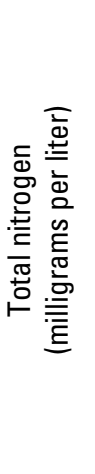 & 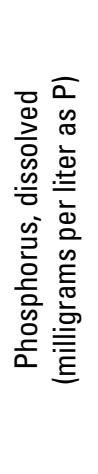 & 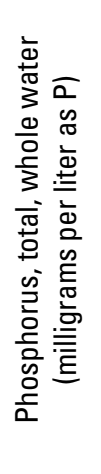 & 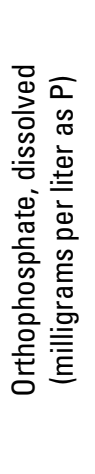 & 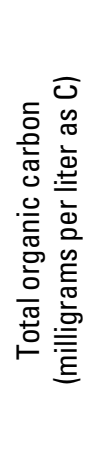 \\
\hline \multicolumn{14}{|c|}{ Synoptic survey III-Continued } \\
\hline \multirow[t]{7}{*}{33} & Kansas River at DeSoto & 6892350 & $7 / 25 / 02$ & 1130 & 31.7 & $<0.02$ & 0.40 & 1.4 & 1.5 & 0.05 & 0.23 & 0.03 & 12 \\
\hline & & & $7 / 29 / 02$ & 1045 & 31.7 & E.01 & .46 & 1.3 & 1.3 & .11 & .25 & .08 & 9.5 \\
\hline & & & $7 / 29 / 02$ & 1330 & 31.7 & E.01 & .42 & 1.3 & 1.3 & .11 & .24 & .08 & 11.6 \\
\hline & & & $8 / 2 / 02$ & 700 & 31.7 & .08 & .47 & 1.1 & 1.2 & .21 & .33 & .20 & 11.0 \\
\hline & & & $8 / 2 / 02$ & 1300 & 31.7 & .02 & .42 & 1.1 & 1.2 & .18 & .28 & .15 & 9.4 \\
\hline & & & $8 / 6 / 02$ & 1300 & 31.7 & $<.02$ & .40 & 1.3 & 1.3 & .08 & .26 & .06 & 13.7 \\
\hline & & & $8 / 7 / 02$ & 825 & 31.7 & $<.02$ & .42 & 1.5 & 1.5 & .13 & .32 & .11 & 12.1 \\
\hline 34 & DeSoto wastewater-treatment facility & 6892358 & $7 / 29 / 02$ & 830 & 31.0 & 1.5 & 11 & 10 & 10 & 1.7 & 1.8 & 1.6 & 10.6 \\
\hline 35 & Kill Creek at 83rd Street & 6892360 & $7 / 30 / 02$ & 850 & 31.0 & .04 & .31 & .54 & .72 & .09 & .15 & .08 & 4.1 \\
\hline \multirow[t]{2}{*}{36} & Kansas River near Cedar & 6892380 & $7 / 30 / 02$ & 1200 & 30.8 & E.01 & .41 & 1.6 & 1.6 & .13 & .30 & .11 & 13 \\
\hline & & & $7 / 30 / 02$ & 1330 & 30.8 & $<.02$ & .42 & 1.4 & 1.4 & .13 & .30 & .10 & 14 \\
\hline 37 & Cedar Creek near Cedar Junction & 6892490 & $7 / 30 / 02$ & 920 & 26.7 & .06 & .61 & .76 & 5.2 & .47 & .47 & .41 & 6.8 \\
\hline 38 & Kansas River at Bonner Springs & 6892500 & $8 / 6 / 02$ & 910 & 20.7 & $<.02$ & .39 & 1.3 & 1.3 & .04 & .26 & .02 & 14 \\
\hline 39 & Bonner Springs wastewater-treatment facility & 6892502 & $7 / 29 / 02$ & 1330 & 20.3 & .27 & 1.5 & 2.0 & 26 & 6.4 & 6.3 & 5.8 & 11 \\
\hline 40 & Kansas River near Lake of the Forest & 6892504 & $7 / 30 / 02$ & 945 & 19.4 & E.01 & .42 & 1.4 & 1.4 & .10 & .23 & .08 & 9.4 \\
\hline 41 & Kansas River near Edwardsville & 6892505 & $7 / 30 / 02$ & 900 & 16.6 & $<.02$ & .39 & 2.6 & 2.6 & .09 & .25 & .07 & 11 \\
\hline 42 & Mill Creek at Wilder Road & 6892515 & $7 / 30 / 02$ & 1000 & 16.1 & .08 & .45 & .68 & 1.3 & .22 & .24 & .21 & 5.4 \\
\hline 43 & Kansas River near I-435 Bridge & 6892518 & $7 / 30 / 02$ & 745 & 15.4 & $<.02$ & .41 & 1.3 & 1.3 & .08 & .25 & .06 & 10.4 \\
\hline 44 & $\begin{array}{l}\text { Johnson County Mill Creek wastewater- } \\
\text { treatment facility }\end{array}$ & 6892520 & $7 / 29 / 02$ & 930 & 15.0 & 24 & 27 & 25 & 26 & 4.2 & 4.3 & 3.9 & 14.8 \\
\hline
\end{tabular}


Appendix 1. Water-quality results from samples collected from Kansas River, northeast Kansas, selected tributaries, and selected wastewater-treatment facility effluent for synoptic surveys I, II, and III, November 2001 through August 2002.-Continued

$\left[<\right.$, less than; --, not determined; E, estimated; >, greater than; $\mathrm{FNU}$, formazin nephelometric units; $\mathrm{CO}_{3}$, carbonate; $\mathrm{HCO}_{3}$, bicarbonate; $\mathrm{CaCO}_{3}$, calcium carbonate; ${ }^{\circ} \mathrm{C}$, degrees Celsius; $\mathrm{SO}_{4}$, sulfate; $\mathrm{Cl}$, chloride, N, nitrogen; $\mathrm{P}$, phosphorus; $\mathrm{C}$, carbon]

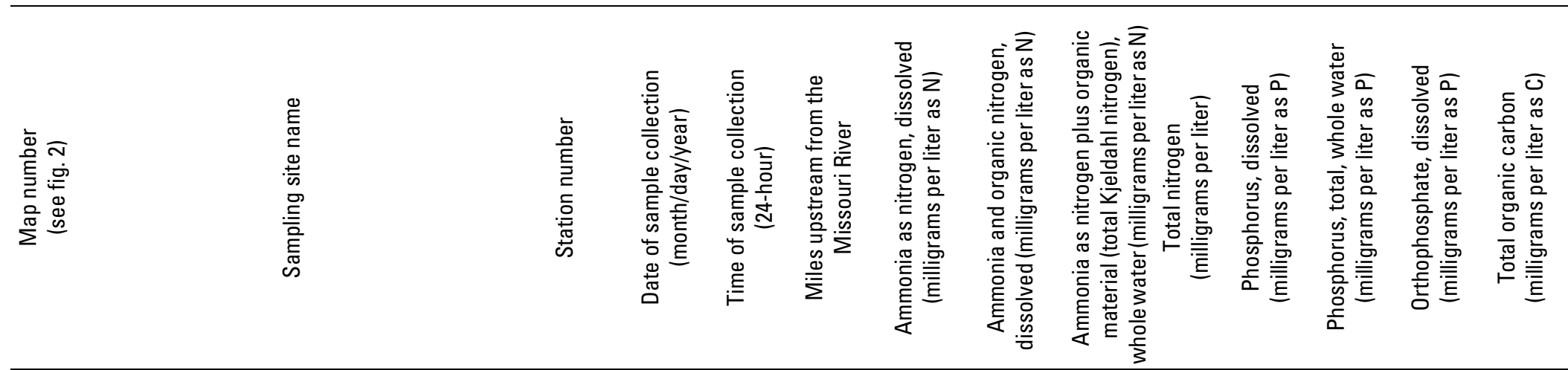

\begin{tabular}{|c|c|c|c|c|c|c|c|c|c|c|c|c|c|}
\hline \multicolumn{14}{|c|}{ Synoptic survey III-Continued } \\
\hline 45 & $\begin{array}{l}\text { Kansas City wastewater-treatment facility } \\
\text { no. } 20\end{array}$ & 6892525 & $7 / 29 / 02$ & 835 & 14.8 & 0.190 & 1.2 & 1.5 & 17 & 2.9 & 2.9 & 2.6 & 8.2 \\
\hline 46 & $\begin{array}{l}\text { Unnamed tributary below Kansas City } \\
\text { wastewater-treatment facility no. } 14\end{array}$ & 6892527 & $7 / 29 / 02$ & 900 & 11.2 & .32 & 1.1 & 2.5 & 17 & 1.6 & 2.2 & 1.5 & 14.4 \\
\hline \multirow[t]{3}{*}{47} & Kansas River at Turner Bridge & 6892530 & $7 / 26 / 02$ & 850 & 9.7 & .15 & .54 & 1.6 & 1.7 & .08 & .26 & .06 & 8.8 \\
\hline & & & $7 / 29 / 02$ & 1030 & 9.7 & .08 & .55 & 1.5 & 1.6 & .13 & .28 & .10 & 11 \\
\hline & & & $8 / 8 / 02$ & 1055 & 9.7 & $<.02$ & .42 & 1.5 & 1.5 & .07 & .32 & .05 & 14 \\
\hline \multirow[t]{2}{*}{48} & Kansas River at west Kansas Avenue Bridge & 6892540 & $7 / 29 / 02$ & 1135 & 6.0 & .17 & 60 & 1.6 & 1.7 & .13 & .29 & .10 & 11 \\
\hline & & & $8 / 8 / 02$ & 1150 & 6.0 & $<.02$ & .40 & 1.7 & 1.7 & .09 & .34 & .06 & 12 \\
\hline 49 & Turkey Creek at Kansas City near I-35 & 6892942 & $7 / 30 / 02$ & 1100 & 3.2 & 1.9 & 3.8 & 4.8 & 14 & 2.6 & 2.8 & 2.4 & 21 \\
\hline \multirow[t]{4}{*}{50} & Kansas River above Missouri River & 6892960 & $7 / 26 / 02$ & 1035 & 1.1 & .19 & .68 & 1.6 & 1.8 & .13 & .29 & .11 & 8.9 \\
\hline & confluence & & $7 / 29 / 02$ & 830 & 1.1 & .22 & .78 & 1.5 & 1.9 & .21 & .36 & .19 & 11 \\
\hline & & & $8 / 7 / 02$ & 1325 & 1.1 & $<.02$ & .42 & 1.7 & 1.8 & .13 & .33 & .11 & 14 \\
\hline & & & $8 / 8 / 02$ & 900 & 1.1 & $<.02$ & .42 & 1.4 & 1.4 & .11 & .35 & .09 & 11 \\
\hline
\end{tabular}


Appendix 1. Water-quality results from samples collected from Kansas River, northeast Kansas, selected tributaries, and selected wastewater-treatment facility effluent for synoptic surveys I, II, and III, November 2001 through August 2002.-Continued

$\left[<\right.$, less than; --, not determined; E, estimated; >, greater than; $\mathrm{FNU}$, formazin nephelometric units; $\mathrm{CO}_{3}$, carbonate; $\mathrm{HCO}_{3}$, bicarbonate; $\mathrm{CaCO}_{3}$, calcium carbonate; ${ }^{\circ} \mathrm{C}$, degrees Celsius; $\mathrm{SO}_{4}$, sulfate; $\mathrm{Cl}$, chloride, $\mathrm{N}$, nitrogen; $\mathrm{P}$, phosphorus; $\mathrm{C}$, carbon]

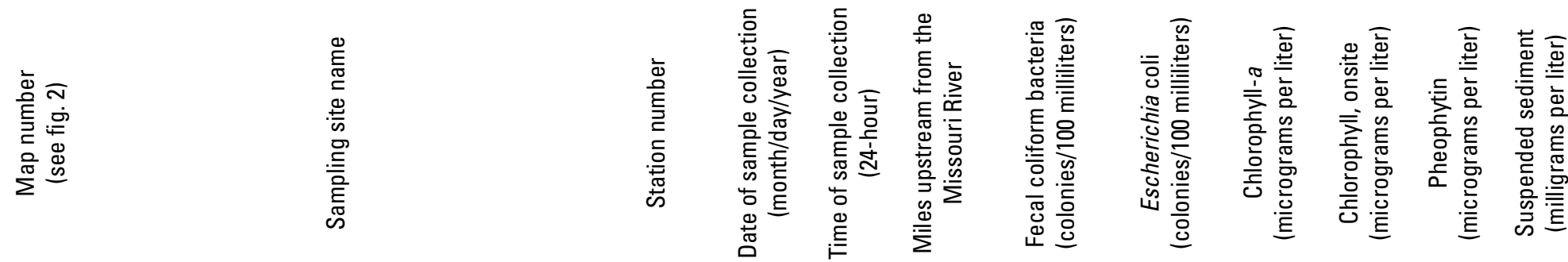

10 Kansas River at Highway 75, Topeka

11 North Topeka wastewater-treatment facility

13 Topeka Oakland wastewater-treatment facility

15 Soldier Creek, Meriden Road, near Topeka

16 Shunganunga Creek at Rice Road, Topeka

18 Muddy Creek near Grantville

20 Delaware River below Perry Dam

21 Kansas River at Lecompton

25 Lawrence wastewater-treatment facility

27 Farmland nitrogen wastewater-treatment facility, Lawrence

29 Mud Creek near Lawrence

30 Kansas River at Eudora

31 Wakarusa River at 1900 Road near Eudora

32 Stranger Creek above Linwood

35 Kill Creek at 83rd Street

37 Cedar Creek near Cedar Junction

39 Bonner Springs wastewater-treatment facility

\section{Synoptic survey}

$6888980 \quad 11 / 29 / 01 \quad 1100$

$688898511 / 28 / 01 \quad 1220$

$6889002 \quad 11 / 28 / 01 \quad 1115$

$6889504 \quad 11 / 29 / 01 \quad 930$

$6889700 \quad 11 / 29 / 01 \quad 1030$

$6889800 \quad 11 / 28 / 01 \quad 850$

$6890900 \quad 11 / 28 / 01 \quad 920$

$6891000 \quad 11 / 28 / 01 \quad 1330$

$6891090 \quad 11 / 28 / 01 \quad 920$

$6891095 \quad 11 / 28 / 01 \quad 845$

\section{0}

85.0

81.7

80.5

76.0

72.3

65.1

64.0

51.1

50.1

$6891098 \quad 11 / 27 / 01 \quad 1145$

$6891100 \quad 11 / 28 / 01 \quad 1030$

$6891675 \quad 11 / 27 / 01 \quad 755$

$6892200 \quad 11 / 27 / 01 \quad 1240$

$6892360 \quad 11 / 27 / 01 \quad 1015$

$6892490 \quad 11 / 27 / 01 \quad 830$

$6892502 \quad 11 / 29 / 01 \quad 1010$
47.6

43.4

42.6

35.4

31.0

26.7

20.3

$\begin{array}{rrcccr}52 & \text { E60 } & \text { E3.4 } & 17 & \text { E7 } & 24 \\ 2,500 & 2,400 & -- & 6.7 & -- & 17 \\ 250 & 220 & -- & 6.6 & -- & 8 \\ \text { E16 } & \text { E12 } & -- & 5.6 & -- & 8 \\ 63 & \text { E40 } & -- & 6.3 & -- & 8 \\ & & & & & \\ 30 & \text { E33 } & -- & 2.9 & -- & 9 \\ 80 & 4 & -- & 5.6 & -- & 44 \\ 120 & >800 & 10 & 15 & 8 & 19 \\ 87 & \text { E110 } & -- & 4.6 & -- & 13 \\ 230 & 170 & \text { E85 } & 100 & \text { E70 } & 41\end{array}$

\section{E33}

45

E12

22

E30

E7 
Appendix 1. Water-quality results from samples collected from Kansas River, northeast Kansas, selected tributaries, and selected wastewater-treatment facility effluent for synoptic surveys I, II, and III, November 2001 through August 2002.-Continued

$\left[<\right.$, less than; --, not determined; E, estimated; >, greater than; $\mathrm{FNU}$, formazin nephelometric units; $\mathrm{CO}_{3}$, carbonate; $\mathrm{HCO}_{3}$, bicarbonate; $\mathrm{CaCO}_{3}$, calcium carbonate; ${ }^{\circ} \mathrm{C}$, degrees Celsius; $\mathrm{SO}_{4}$, sulfate; $\mathrm{Cl}$, chloride, $\mathrm{N}$, nitrogen; $\mathrm{P}$, phosphorus; $\mathrm{C}$, carbon]

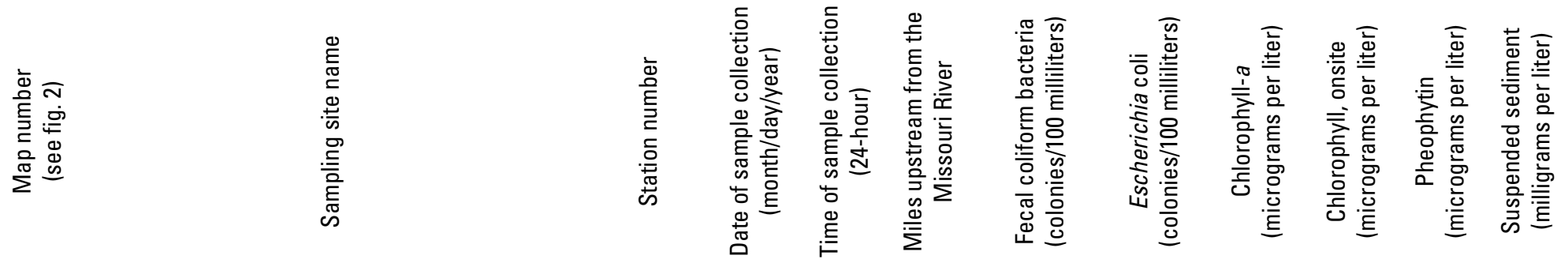

\footnotetext{
42 Mill Creek at Wilder Road

44 Johnson County Mill Creek wastewater-treatment facility

45 Kansas City wastewater-treatment facility no. 20

46 Unnamed tributary below Kansas City wastewatertreatment facility no. 14

48 Kansas River at west Kansas Avenue Bridge

49 Turkey Creek at Kansas City near I-35

50 Kansas River above Missouri River confluence

2 Vermillion Creek near Wamego

3 Rock Creek near Louisville

Kansas River at Belvue

5 Kansas River near Maple Hill

6 Mill Creek near Maple Hill

7 Cross Creek near Rossville

8 Kansas River at Willard

9 Mission Creek near Valencia

10 Kansas River at Highway 75, Topeka
}

Synoptic survey l-Continued $6892515 \quad 11 / 27 / 01 \quad 845 \quad 16$.

$\begin{array}{llll}6892520 & 11 / 27 / 01 & 1215 & 15.0\end{array}$

6.1
5.0

120

E53

$\begin{array}{llll}6892525 & 11 / 27 / 01 & 930 & 14.8\end{array}$ $6892527 \quad 11 / 27 / 01 \quad 1100 \quad 11.2$

$6892540 \quad 11 / 28 / 01 \quad 1010$

6.0

$\begin{array}{rr}\text { E60 } & 110 \\ 37,000 & 58,000\end{array}$

\begin{tabular}{cccc}
6892942 & $11 / 27 / 01$ & 1030 & 3.2 \\
6892960 & $11 / 27 / 01$ & 1230 & 1.1 \\
\multicolumn{3}{c}{ Synoptic survey II }
\end{tabular}

E1,000 E940

$\begin{array}{llll}14 & 27 & 20 & 26\end{array}$

$\begin{array}{llll}6888000 & 2 / 28 / 02 & 1310 & 119.2\end{array}$

$6888300 \quad 2 / 28 / 02 \quad 1215-118.2$

$\begin{array}{llll}6888350 & 2 / 28 / 02 & 1315 & 113.0\end{array}$

$6888400 \quad 2 / 28 / 02 \quad 1135 \quad 103.7$

$\begin{array}{llll}6888650 & 2 / 28 / 02 & 1015 & 101.7\end{array}$

$450 \quad 970$

$100 \quad \mathrm{E} 130$

$\begin{array}{llll}-- & 6.0 & -- & 8\end{array}$

$\begin{array}{llll}6888700 & 2 / 28 / 02 & 1400 & 100.1\end{array}$

$\begin{array}{llll}6888705 & 2 / 28 / 02 & 950 & 98.9\end{array}$

$\begin{array}{llll}6888800 & 2 / 28 / 02 & 900 & 91.6\end{array}$

$\begin{array}{llll}6888980 & 2 / 28 / 02 & 1115 & 86.0\end{array}$

$\begin{array}{rrrcrr}\text { E1 } & 0 & -- & 2.9 & -- & 12 \\ 0 & 0 & -- & 2.9 & -- & 12 \\ \text { E3 } & 0 & -- & 7.0 & -- & 31 \\ \text { E1 } & 0 & -- & 7.0 & -- & 87 \\ \text { E13 } & 22 & -- & 3.6 & -- & 35 \\ & & & & & \\ 0 & \text { E0 } & -- & 3.2 & -- & 17 \\ 0 & \text { E10 } & -- & 10 & -- & 85 \\ \text { E1 } & \text { E0 } & -- & 4.3 & -- & 9 \\ \text { E1 } & \text { E1 } & -- & 9.0 & -- & 39\end{array}$


Appendix 1. Water-quality results from samples collected from Kansas River, northeast Kansas, selected tributaries, and selected wastewater-treatment facility effluent for synoptic surveys I, II, and III, November 2001 through August 2002.-Continued

$\left[<\right.$, less than; --, not determined; E, estimated; >, greater than; $\mathrm{FNU}$, formazin nephelometric units; $\mathrm{CO}_{3}$, carbonate; $\mathrm{HCO}_{3}$, bicarbonate; $\mathrm{CaCO}_{3}$, calcium carbonate; ${ }^{\circ} \mathrm{C}$, degrees Celsius; $\mathrm{SO}_{4}$, sulfate; $\mathrm{Cl}$, chloride, $\mathrm{N}$, nitrogen; $\mathrm{P}$, phosphorus; $\mathrm{C}$, carbon]

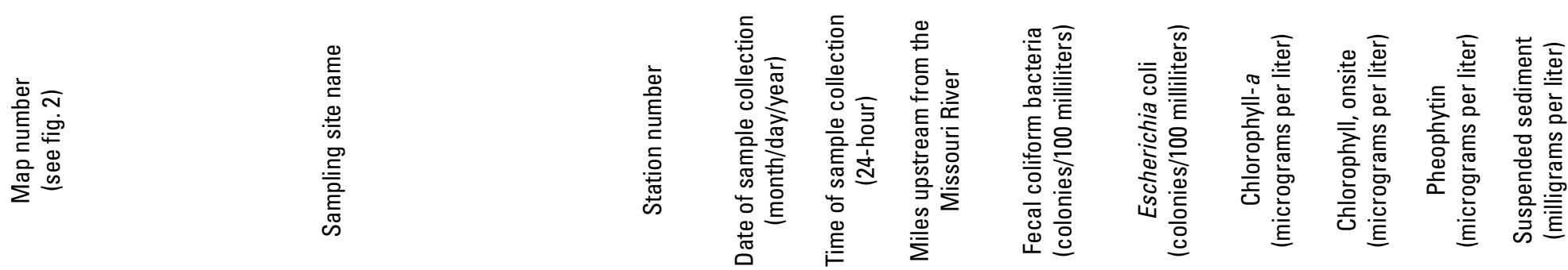

11 North Topeka wastewater-treatment facility

12 Kansas River at Topeka

13 Topeka Oakland wastewater-treatment facility

14 Kansas River at Highway 4, Topeka

15 Soldier Creek, Meriden Road, near Topeka

16 Shunganunga Creek at Rice Road, Topeka

17 Kansas River near Grantville

18 Muddy Creek near Grantville

19 Kansas River near Grover

20 Delaware River below Perry Dam

21 Kansas River at Lecompton

22 Buck Creek at Williamstown

23 Kansas River near Midland

24 Kansas River at Lawrence

25 Lawrence wastewater-treatment facility

26 Kansas River between Lawrence and Farmland facility

27 Farmland nitrogen wastewater-treatment facility, Lawrence
Synoptic survey II-Continued

$6888985 \quad 2 / 26 / 02 \quad 1130 \quad 85.0$

$\begin{array}{llll}6889000 & 2 / 27 / 02 & 1320 & 83.0\end{array}$

$\begin{array}{llll}6889002 & 2 / 26 / 02 & 1045 & 81.7\end{array}$

$\begin{array}{llll}6889010 & 2 / 28 / 02 & 855 & 81.1\end{array}$

$\begin{array}{llll}6889504 & 2 / 27 / 02 & 1215 & 80.5\end{array}$

$\begin{array}{llll}6889700 & 2 / 27 / 02 & 1315 & 76.0\end{array}$

$\begin{array}{lllll}6889750 & 2 / 28 / 02 & 1100 & 73.7\end{array}$

$\begin{array}{llll}6889800 & 2 / 27 / 02 & 900 & 72.3\end{array}$

$\begin{array}{llll}6889850 & 2 / 28 / 02 & 1330 & 68.6\end{array}$

$\begin{array}{llll}6890900 & 2 / 27 / 02 & 930 & 65.1\end{array}$

$6891000 \quad 2 / 27 / 02 \quad 1025 \quad 64.0$

$\begin{array}{llll}6891060 & 2 / 27 / 02 & 1015 & 58.6\end{array}$

$\begin{array}{llll}6891070 & 3 / 1 / 02 & 935 & 57.5\end{array}$

$\begin{array}{llll}6891080 & 2 / 27 / 02 & 1020 & 51.9\end{array}$

$\begin{array}{llll}6891090 & 2 / 25 / 02 & 1305 & 51.1\end{array}$

$6891093 \quad 2 / 27 / 02 \quad 1115 \quad 50.6$

$6891095 \quad 2 / 26 / 02 \quad 840 \quad 50.1$

$\begin{array}{rrcccr}270 & \text { E220 } & -- & 4.1 & -- & 7 \\ 0 & \text { E7 } & -- & 10 & -- & 50 \\ \text { E3,600 } & \text { E2,600 } & -- & 5.2 & -- & 8 \\ \text { E5 } & \text { E10 } & -- & 19 & -- & 64 \\ \text { E3 } & \text { E0 } & -- & 4.3 & -- & 13 \\ & & & & & \\ \text { E4 } & \text { E7 } & -- & 5.4 & -- & 20 \\ \text { E16 } & \text { E14 } & -- & -- & -- & 40 \\ 60 & \text { E9 } & -- & 3.4 & -- & 13 \\ \text { E2 } & \text { E30 } & -- & -- & -- & 44 \\ \text { E2 } & \text { E4 } & -- & 15 & -- & 12 \\ & & & & & \\ \text { E6 } & \text { E0 } & -- & 22 & -- & 93 \\ 0 & \text { E1 } & -- & 3.2 & -- & 16 \\ \text { E8 } & \text { E0 } & -- & 26 & -- & 48 \\ 0 & \text { E3 } & -- & 35 & -- & 43 \\ \text { E2,100 } & \text { E2,200 } & -- & 4.6 & -- & 15 \\ & & & & & \\ 0 & \text { E0 } & -- & 540 & -- & 28 \\ \text { E6 } & \text { E5 } & -- & 12 & - & 41 \\ & & & & & \end{array}$


Appendix 1. Water-quality results from samples collected from Kansas River, northeast Kansas, selected tributaries, and selected wastewater-treatment facility effluent for synoptic surveys I, II, and III, November 2001 through August 2002.-Continued

$\left[<\right.$, less than; --, not determined; E, estimated; >, greater than; $\mathrm{FNU}$, formazin nephelometric units; $\mathrm{CO}_{3}$, carbonate; $\mathrm{HCO}_{3}$, bicarbonate; $\mathrm{CaCO}_{3}$, calcium carbonate; ${ }^{\circ} \mathrm{C}$, degrees Celsius; $\mathrm{SO}_{4}$, sulfate; $\mathrm{Cl}$, chloride, $\mathrm{N}$, nitrogen; $\mathrm{P}$, phosphorus; $\mathrm{C}$, carbon]

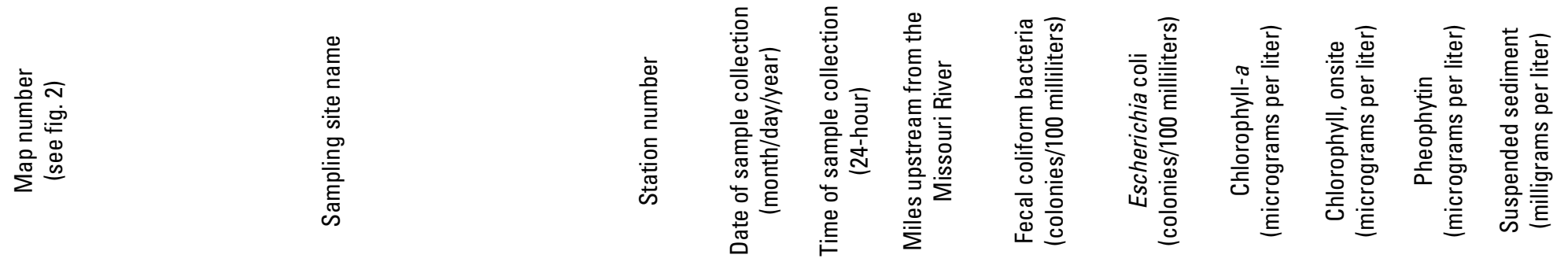

\footnotetext{
28 Kansas River below Farmland facility

29 Mud Creek near Lawrence

30 Kansas River at Eudora

31 Wakarusa River at 1900 Road near Eudora

32 Stranger Creek above Linwood

33 Kansas River at DeSoto

34 DeSoto wastewater-treatment facility

35 Kill Creek at 83rd Street

36 Kansas River near Cedar

37 Cedar Creek near Cedar Junction

38 Kansas River at Bonner Springs

39 Bonner Springs wastewater-treatment facility

40 Kansas River near Lake of the Forest

41 Kansas River near Edwardsville

42 Mill Creek at Wilder Road

43 Kansas River near I-435 Bridge

44 Johnson County Mill Creek wastewater-treatment facility
}

Synoptic survey II-Continued

$\begin{array}{llll}6891096 & 2 / 27 / 02 & 1300 \quad 48.6\end{array}$

$6891098 \quad 2 / 26 / 02 \quad 1045 \quad 47.6$

$\begin{array}{llll}6891100 & 2 / 25 / 02 & 930 & 43.4\end{array}$

$\begin{array}{llll}6891675 & 2 / 26 / 02 & 900 \quad 42.6\end{array}$

$\begin{array}{llll}6892200 & 2 / 26 / 02 & 1145 \quad 35.4\end{array}$

$\begin{array}{llll}6892350 & 2 / 25 / 02 & 1230 & 31.7\end{array}$

$\begin{array}{llll}6892358 & 2 / 25 / 02 & 830 & 31.0\end{array}$

$\begin{array}{llll}6892360 & 2 / 25 / 02 & 915 & 31.0\end{array}$

$\begin{array}{llll}6892380 & 2 / 26 / 02 & 1230 & 30.8\end{array}$

$\begin{array}{llll}6892490 & 2 / 25 / 02 & 1315 & 26.7\end{array}$

$\begin{array}{llll}6892500 & 2 / 26 / 02 & 1030 & 20.7\end{array}$

$\begin{array}{llll}6892502 & 2 / 26 / 02 & 945 & 20.3\end{array}$

$\begin{array}{llll}6892504 & 2 / 26 / 02 & 1005 & 19.4\end{array}$

$6892505 \quad 2 / 26 / 02 \quad 1130 \quad 16.6$

$\begin{array}{llll}6892515 & 2 / 25 / 02 & 1015 & 16.1\end{array}$

$\begin{array}{llll}6892518 & 2 / 26 / 02 & 925 & 15.4\end{array}$

$6892520 \quad 2 / 25 / 02 \quad 1150$

15.0

$\begin{array}{rrcccc}\text { E5 } & 0 & -- & 490 & -- & 18 \\ \text { E7 } & \text { E16 } & -- & 4.1 & -- & 35 \\ \text { E250 } & \text { E210 } & -- & 42 & -- & 55 \\ \text { E6 } & \text { E5 } & -- & 6.2 & -- & 40 \\ \text { E10 } & \text { E9 } & -- & 4.5 & -- & 36 \\ & & & & & \end{array}$

E7,300 E5 200

$\begin{array}{llll}-- & 61 & -- & 68\end{array}$

$\begin{array}{llll}-- & 4.6 & -- & 14\end{array}$

$\begin{array}{llll}- & 9.2 & - & \end{array}$

$\begin{array}{llll}-- & -- & -- & 40\end{array}$

$\begin{array}{llll}-- & 5.0 & -- & 24\end{array}$

60 E1

23

40

$\begin{array}{llll}-- & 46 & -- & 71\end{array}$

$\begin{array}{cccc}-- & 46 & - & 71 \\ -- & 3.5 & -- & 6\end{array}$

$\begin{array}{llll}-- & 54 & -- & 84\end{array}$

$\begin{array}{llll}- & 54 & -- & 84 \\ -- & 97 & -- & 85\end{array}$

$\begin{array}{llll}-- & 5.6 & -- & 27\end{array}$

$\begin{array}{llll}-- & 89 & -- & 73\end{array}$

$\begin{array}{llll}- & 6.2 & -- & 25\end{array}$ 
Appendix 1. Water-quality results from samples collected from Kansas River, northeast Kansas, selected tributaries, and selected wastewater-treatment facility effluent for synoptic surveys I, II, and III, November 2001 through August 2002.-Continued

$\left[<\right.$, less than; --, not determined; E, estimated; >, greater than; $\mathrm{FNU}$, formazin nephelometric units; $\mathrm{CO}_{3}$, carbonate; $\mathrm{HCO}_{3}$, bicarbonate; $\mathrm{CaCO}_{3}$, calcium carbonate; ${ }^{\circ} \mathrm{C}$, degrees Celsius; $\mathrm{SO}_{4}$, sulfate; $\mathrm{Cl}$, chloride, $\mathrm{N}$, nitrogen; $\mathrm{P}$, phosphorus; $\mathrm{C}$, carbon]

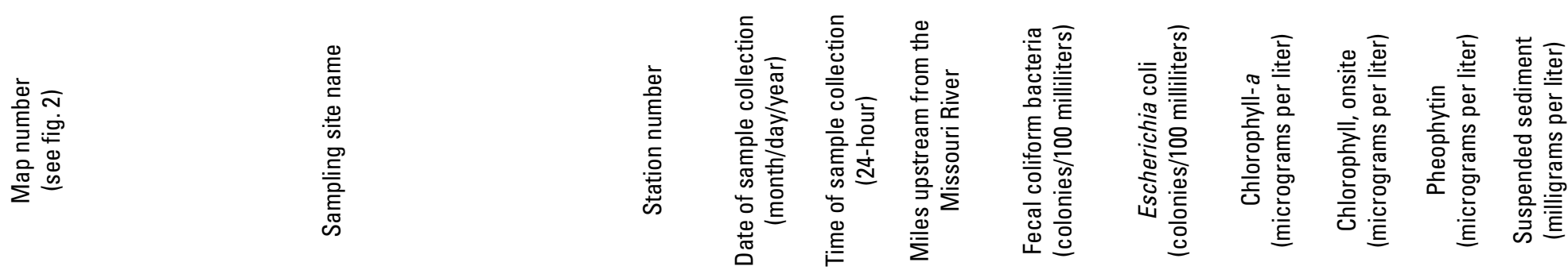

\begin{tabular}{|c|c|c|c|c|c|c|c|c|c|c|c|}
\hline \multicolumn{12}{|c|}{ Synoptic survey II-Continued } \\
\hline 45 & Kansas City wastewater-treatment facility no. 20 & 6892525 & $2 / 25 / 02$ & 1000 & 14.8 & 69 & 130 & -- & 3.8 & -- & 5 \\
\hline 46 & $\begin{array}{l}\text { Unnamed tributary below Kansas City wastewater- } \\
\text { treatment facility no. } 14\end{array}$ & 6892527 & $2 / 25 / 02$ & 1030 & 11.2 & E500 & E300 & -- & 2.2 & -- & 25 \\
\hline 47 & Kansas River at Turner Bridge & 6892530 & $2 / 25 / 02$ & 1235 & 9.7 & E18 & E12 & -- & 89 & -- & 103 \\
\hline 48 & Kansas River at west Kansas Avenue Bridge & 6892540 & $2 / 25 / 02$ & 1050 & 6.0 & E33 & E33 & -- & 80 & -- & 120 \\
\hline 49 & Turkey Creek at Kansas City near I-35 & 6892942 & $2 / 25 / 02$ & 1120 & 3.2 & 150 & E210 & -- & 4.0 & -- & 8 \\
\hline 50 & Kansas River above Missouri River confluence & 6892960 & $2 / 25 / 02$ & 745 & 1.1 & 36 & E28 & -- & 81 & -- & 107 \\
\hline \multicolumn{12}{|c|}{ Synoptic survey III } \\
\hline 1 & Kansas River at Wamego & 6887500 & $7 / 31 / 02$ & 1005 & 124.0 & -- & -- & 120 & 62 & 26 & 79 \\
\hline 2 & Vermillion Creek near Wamego & 6888000 & $8 / 1 / 02$ & 1020 & 119.2 & E170 & -- & E38 & -- & E18 & 25 \\
\hline 3 & Rock Creek near Louisville & 6888300 & $8 / 1 / 02$ & 945 & 118.2 & 140 & -- & E11 & -- & E3 & 41 \\
\hline 4 & Kansas River at Belvue & 6888350 & $7 / 31 / 02$ & 1205 & 113.0 & $>500$ & -- & 84 & 52 & 22 & 99 \\
\hline 5 & Kansas River near Maple Hill & 6888400 & $7 / 31 / 02$ & 750 & 103.7 & -- & -- & 51 & 22 & 17 & 68 \\
\hline 6 & Mill Creek near Maple Hill & 6888650 & $8 / 1 / 02$ & 1130 & 101.7 & 150 & -- & E15 & -- & E7 & 12 \\
\hline 7 & Cross Creek near Rossville & 6888700 & $7 / 31 / 02$ & 1155 & 100.1 & 240 & -- & 27 & -- & 8 & 46 \\
\hline 8 & Kansas River at Willard & 6888705 & $7 / 31 / 02$ & 1020 & 98.9 & 55 & -- & 46 & 17 & 16 & 134 \\
\hline 9 & Mission Creek near Valencia & 6888800 & $8 / 1 / 02$ & 1210 & 91.6 & E700 & -- & E11 & -- & E6 & 17 \\
\hline 10 & Kansas River at Highway 75, Topeka & 6888980 & $7 / 31 / 02$ & 1220 & 86.0 & 53 & -- & 60 & 28 & 23 & 64 \\
\hline
\end{tabular}


$\left[<\right.$, less than; --, not determined; E, estimated; >, greater than; $\mathrm{FNU}$, formazin nephelometric units; $\mathrm{CO}_{3}$, carbonate; $\mathrm{HCO}_{3}$, bicarbonate; $\mathrm{CaCO}_{3}$, calcium carbonate; ${ }^{\circ} \mathrm{C}$, degrees Celsius; $\mathrm{SO}_{4}$, sulfate; $\mathrm{Cl}$, chloride, $\mathrm{N}$, nitrogen; $\mathrm{P}$, phosphorus; $\mathrm{C}$, carbon]

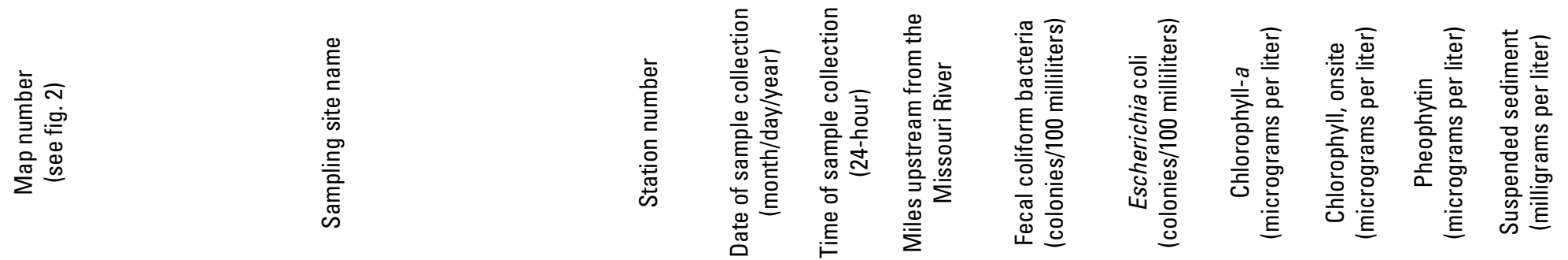

Synoptic survey III-Continued

11 North Topeka wastewater-treatment facility, Topeka $6888985 \quad 7 / 30 / 02 \quad 845 \quad 85.0$

12 Kansas River at Topeka

$\begin{array}{llll}6889000 & 7 / 23 / 02 & 1005 & 83.0\end{array}$

$8 / 2 / 02 \quad 855 \quad 83.0$

$8 / 2 / 02 \quad 1500 \quad 83.0$

$8 / 5 / 02 \quad 1515 \quad 83.0$

$8 / 6 / 02 \quad 900 \quad 83.0$

13 Topeka Oakland wastewater-treatment facility

14 Kansas River at Highway 4, Topeka

$\begin{array}{llll}6889002 & 7 / 30 / 02 & 815 & 81.7\end{array}$

$\begin{array}{llll}6889010 & 7 / 31 / 02 & 1340 \quad 81.1\end{array}$

$8 / 1 / 02 \quad 735 \quad 81.1$

15 Soldier Creek, Meriden Road, near Topeka

$6889504 \quad 7 / 31 / 02 \quad 1300 \quad 80.5$

16 Shunganunga Creek at Rice Road, Topeka

17 Kansas River near Grantville

18 Muddy Creek near Grantville

19 Kansas River near Grover

20 Delaware River below Perry Dam

$\begin{array}{llll}6889700 & 7 / 31 / 02 & 1040 & 76.0\end{array}$

$\begin{array}{llll}6889750 & 7 / 31 / 02 & 1100 & 73.7\end{array}$

$\begin{array}{llll}6889800 & 7 / 31 / 02 & 1000 & 72.3\end{array}$

$6889850 \quad 7 / 31 / 02$

$900 \quad 68.6$

$1400 \quad 68.6$

$\begin{array}{llll}6890900 & 7 / 30 / 02 & 1210 & 65.1\end{array}$

$--\quad 1$

$3.2 \quad 1$

3

51

$-$

44

$22 \quad 20$

E21

-- $\quad$ E49

$21 \quad$ E20

45

$$
--\quad 53
$$

23

$\mathrm{E} 1,800$

$>500$

160

58

-- E31

$\begin{array}{ll}-- & 1\end{array}$

97

-- E50

-- 17

$>5,000$

$\begin{array}{ll}-- & 72\end{array}$

500

$-$

$-$

8

E120

E75

-- $\quad 80$

$\begin{array}{ll}- & 80 \\ -- & 29\end{array}$

-- E19

$16 \quad 13$

13 E14

$8.6<1$

$31 \quad 23$

22 E22

$--\quad 11$

$\begin{array}{lll}-- & 19 & 30\end{array}$

$\begin{array}{lll}22 & 24 & 35\end{array}$

$\begin{array}{lll}-- & 5 & 19\end{array}$

$\begin{array}{lll}31 & 26 & 40\end{array}$

21 Kansas River at Lecompton

$\begin{array}{llll}6891000 & 7 / 22 / 02 & 1345 & 64.0 \\ & 8 / 1 / 02 & 950 & 64.0 \\ & 8 / 1 / 02 & 1400 & 64.0 \\ & 8 / 6 / 02 & 1430 & 64.0\end{array}$

$\begin{array}{rrrrrr}27 & -- & 83 & 35 & 26 & -- \\ 29 & -- & \text { E90 } & 43 & \text { E49 } & 56 \\ 23 & -- & \text { E96 } & 39 & \text { E54 } & -- \\ 0 & -- & \text { E89 } & 34 & \text { E35 } & --\end{array}$


Appendix 1. Water-quality results from samples collected from Kansas River, northeast Kansas, selected tributaries, and selected wastewater-treatment facility effluent for synoptic surveys I, II, and III, November 2001 through August 2002.-Continued

$\left[<\right.$, less than; --, not determined; E, estimated; >, greater than; $\mathrm{FNU}$, formazin nephelometric units; $\mathrm{CO}_{3}$, carbonate; $\mathrm{HCO}_{3}$, bicarbonate; $\mathrm{CaCO}_{3}$, calcium carbonate; ${ }^{\circ} \mathrm{C}$, degrees Celsius; $\mathrm{SO}_{4}$, sulfate; $\mathrm{Cl}$, chloride, $\mathrm{N}$, nitrogen; $\mathrm{P}$, phosphorus; $\mathrm{C}$, carbon]

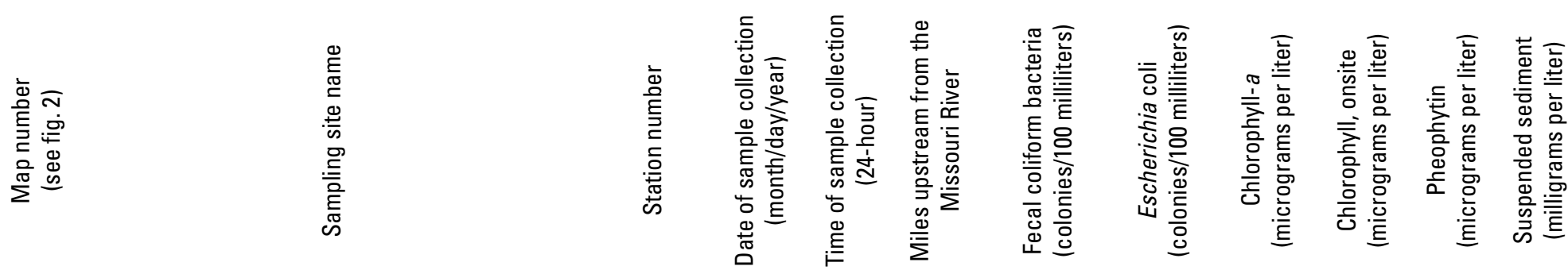

\begin{tabular}{|c|c|c|c|c|c|c|c|c|c|c|c|}
\hline \multicolumn{12}{|c|}{ Synoptic survey III-Continued } \\
\hline 21 & Kansas River at Lecompton & 6891000 & $8 / 7 / 02$ & 850 & 64.0 & 34 & -- & 52 & 25 & 26 & -- \\
\hline 22 & Buck Creek at Williamstown & 6891060 & $7 / 31 / 02$ & 900 & 58.6 & 2,100 & -- & 5 & -- & 5 & 25 \\
\hline 23 & Kansas River near Midland & 6891070 & $8 / 1 / 02$ & 1120 & 57.5 & 22 & -- & E110 & 42 & $\mathrm{E} 42$ & 41 \\
\hline 24 & Kansas River at Lawrence & 6891080 & $8 / 1 / 02$ & 1220 & 51.9 & E5 & -- & E57 & 31 & E53 & 40 \\
\hline 25 & Lawrence wastewater-treatment facility & 6891090 & $7 / 29 / 02$ & 1120 & 51.1 & E31 & -- & 14 & 4.7 & 5 & 1 \\
\hline \multirow[t]{2}{*}{26} & \multirow{2}{*}{$\begin{array}{l}\text { Kansas River between Lawrence and Farmland } \\
\text { facility }\end{array}$} & \multirow[t]{2}{*}{6891093} & $8 / 1 / 02$ & 830 & 50.6 & 32 & -- & E31 & 21 & E39 & 85 \\
\hline & & & $8 / 1 / 02$ & 1100 & 50.6 & E18 & -- & E28 & 22 & E39 & -- \\
\hline 27 & $\begin{array}{l}\text { Farmland nitrogen wastewater-treatment facility, } \\
\text { Lawrence }\end{array}$ & 6891095 & $7 / 29 / 02$ & 1225 & 50.1 & $>3,000$ & -- & 160 & 23 & 60 & 54 \\
\hline 28 & Kansas River below Farmland facility & 6891096 & $8 / 1 / 02$ & 930 & 48.6 & $\mathrm{E} 10$ & -- & E34 & 18 & E33 & 39 \\
\hline 29 & Mud Creek near Lawrence & 6891098 & $7 / 31 / 02$ & 825 & 47.6 & 130 & -- & 20 & -- & 8 & 26 \\
\hline 30 & Kansas River at Eudora & 6891100 & $7 / 29 / 02$ & 900 & 43.4 & E710 & -- & 44 & 22 & 32 & 47 \\
\hline 31 & Wakarusa River at 1900 Road near Eudora & 6891675 & $7 / 30 / 02$ & 820 & 42.6 & E140 & -- & 6 & -- & 3 & 112 \\
\hline 32 & Stranger Creek above Linwood & 6892200 & $7 / 30 / 02$ & 1245 & 35.4 & 20 & -- & 20 & -- & 7 & 26 \\
\hline \multirow[t]{6}{*}{33} & \multirow[t]{6}{*}{ Kansas River at DeSoto } & \multirow[t]{6}{*}{6892350} & $7 / 25 / 02$ & 1130 & 31.7 & E12 & -- & 44 & 67 & 32 & -- \\
\hline & & & $7 / 29 / 02$ & 1045 & 31.7 & 28 & -- & 51 & 24 & 28 & 38 \\
\hline & & & $7 / 29 / 02$ & 1330 & 31.7 & E14 & -- & 65 & 25 & 22 & -- \\
\hline & & & $8 / 2 / 02$ & 700 & 31.7 & E14 & -- & E31 & 17 & E27 & -- \\
\hline & & & $8 / 2 / 02$ & 1300 & 31.7 & E10 & -- & E34 & 13 & E24 & -- \\
\hline & & & $8 / 6 / 02$ & 1300 & 31.7 & 20 & -- & E84 & 53 & E38 & -- \\
\hline
\end{tabular}


Appendix 1. Water-quality results from samples collected from Kansas River, northeast Kansas, selected tributaries, and selected wastewater-treatment facility effluent for synoptic surveys I, II, and III, November 2001 through August 2002.-Continued

$\left[<\right.$, less than; --, not determined; E, estimated; >, greater than; $\mathrm{FNU}$, formazin nephelometric units; $\mathrm{CO}_{3}$, carbonate; $\mathrm{HCO}_{3}$, bicarbonate; $\mathrm{CaCO}_{3}$, calcium carbonate; ${ }^{\circ} \mathrm{C}$, degrees Celsius; $\mathrm{SO}_{4}$, sulfate; $\mathrm{Cl}$, chloride, $\mathrm{N}$, nitrogen; $\mathrm{P}$, phosphorus; $\mathrm{C}$, carbon]

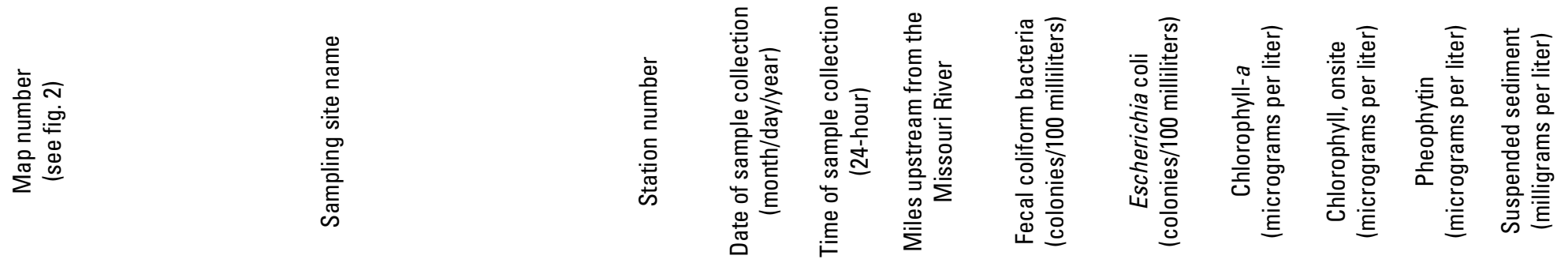

\begin{tabular}{|c|c|c|c|c|c|c|c|c|c|c|c|}
\hline \multicolumn{12}{|c|}{ Synoptic survey III-Continued } \\
\hline 33 & Kansas River at DeSoto & 6892350 & $8 / 7 / 02$ & 825 & 31.7 & 33 & -- & 84 & 49 & 47 & -- \\
\hline 34 & DeSoto wastewater-treatment facility & 6892358 & $7 / 29 / 02$ & 830 & 31.0 & $\mathrm{E} 290,000$ & -- & 3 & -- & 1 & 3 \\
\hline 35 & Kill Creek at 83rd Street & 6892360 & $7 / 30 / 02$ & 850 & 31.0 & 130 & -- & 4 & -- & 3 & 58 \\
\hline \multirow[t]{2}{*}{36} & Kansas River near Cedar & 6892380 & $7 / 30 / 02$ & 1200 & 30.8 & E210 & -- & 67 & 37 & 33 & -- \\
\hline & & & $7 / 30 / 02$ & 1330 & 30.8 & E94 & -- & 68 & 37 & 30 & 705 \\
\hline 37 & Cedar Creek near Cedar Junction & 6892490 & $7 / 30 / 02$ & 920 & 26.7 & 130 & -- & 9 & -- & 9 & 33 \\
\hline 38 & Kansas River at Bonner Springs & 6892500 & $8 / 6 / 02$ & 910 & 20.7 & E19 & -- & E69 & 50 & E41 & -- \\
\hline 39 & Bonner Springs wastewater-treatment facility & 6892502 & $7 / 29 / 02$ & 1330 & 20.3 & 56 & -- & 2 & -- & 1 & 2 \\
\hline 40 & Kansas River near Lake of the Forest & 6892504 & $7 / 30 / 02$ & 945 & 19.4 & 22 & -- & 74 & 32 & 34 & 91 \\
\hline 41 & Kansas River near Edwardsville & 6892505 & $7 / 30 / 02$ & 900 & 16.6 & E66 & -- & 66 & 28 & 30 & 68 \\
\hline 42 & Mill Creek at Wilder Road & 6892515 & $7 / 30 / 02$ & 1000 & 16.1 & 180 & -- & 16 & -- & 7 & 18 \\
\hline 43 & Kansas River near I-435 Bridge & 6892518 & $7 / 30 / 02$ & 745 & 15.4 & E75 & -- & 70 & 28 & 34 & 60 \\
\hline 44 & $\begin{array}{l}\text { Johnson County Mill Creek wastewater- } \\
\text { treatment facility }\end{array}$ & 6892520 & $7 / 29 / 02$ & 930 & 15.0 & E35 & -- & 22 & 21 & 20 & 10 \\
\hline 45 & Kansas City wastewater-treatment facility no. 20 & 6892525 & $7 / 29 / 02$ & 835 & 14.8 & E16 & -- & 1 & 4.7 & 1 & 3 \\
\hline 46 & $\begin{array}{l}\text { Unnamed tributary below Kansas City wastewater- } \\
\text { treatment facility no. } 14\end{array}$ & 6892527 & $7 / 29 / 02$ & 900 & 11.2 & -- & -- & 18 & 27 & 24 & 55 \\
\hline \multirow[t]{3}{*}{47} & Kansas River at Turner Bridge & 6892530 & $7 / 26 / 02$ & 850 & 9.7 & E10 & -- & E45 & 25 & E34 & -- \\
\hline & & & $7 / 29 / 02$ & 1030 & 9.7 & E250 & -- & 75 & 26 & 34 & 64 \\
\hline & & & 8/8/02 & 1055 & 9.7 & E13 & -- & 78 & 41 & 40 & -- \\
\hline
\end{tabular}


Appendix 1. Water-quality results from samples collected from Kansas River, northeast Kansas, selected tributaries, and selected wastewater-treatment facility effluent for synoptic surveys I, II, and III, November 2001 through August 2002.—Continued

$\left[<\right.$, less than; --, not determined; E, estimated; >, greater than; $\mathrm{FNU}$, formazin nephelometric units; $\mathrm{CO}_{3}$, carbonate; $\mathrm{HCO}_{3}$, bicarbonate; $\mathrm{CaCO}_{3}$, calcium carbonate; ${ }^{\circ} \mathrm{C}$, degrees Celsius; $\mathrm{SO}_{4}$, sulfate; $\mathrm{Cl}$, chloride, $\mathrm{N}$, nitrogen; $\mathrm{P}$, phosphorus; $\mathrm{C}$, carbon]

\begin{tabular}{|c|c|c|c|c|c|c|c|c|c|c|}
\hline 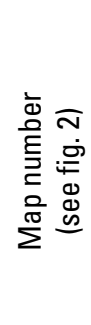 & 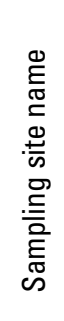 & 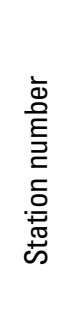 & 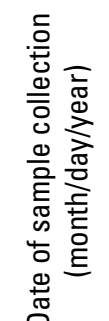 & 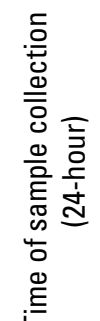 & 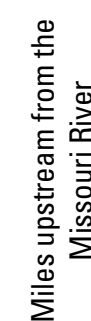 & 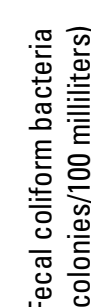 & 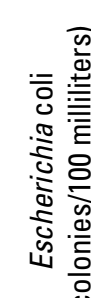 & 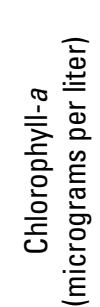 & 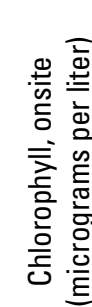 & 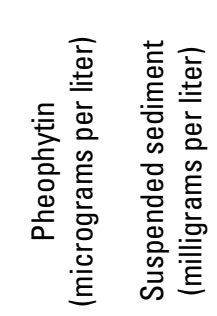 \\
\hline
\end{tabular}

48 Kansas River at west Kansas Avenue Bridge

49 Turkey Creek at Kansas City near I-35

50 Kansas River above Missouri River confluence
Synoptic survey III-Continued

\begin{tabular}{rlllrrrrrr}
6892540 & $7 / 29 / 02$ & 1135 & 6.1 & E120 & -- & 65 & 23 & 35 & 50 \\
& $8 / 8 / 02$ & 1150 & 6.1 & 22 & -- & 99 & 41 & 48 & -- \\
6892942 & $7 / 30 / 02$ & 1100 & 3.2 & 1,300 & -- & 4 & -- & 7 & 6 \\
6892960 & $7 / 26 / 02$ & 1035 & 1.1 & E160 & -- & E37 & 21 & E48 & -- \\
& $7 / 29 / 02$ & 830 & 1.1 & $>4,000$ & -- & 45 & 19 & 33 & 49 \\
& $8 / 7 / 02$ & 1325 & 1.1 & E0 & -- & 120 & 45 & 56 & - \\
& $8 / 8 / 02$ & 900 & 1.1 & E0 & -- & 70 & 37 & 68 & -- \\
\hline
\end{tabular}


Appendix 2. List of wastewater-treatment facilities (WWTFs) that discharge effluent to the Kansas River and its tributary streams in northeast Kansas and design limits.

[Source: M.E. Gerard, Kansas Department of Health and Environment, written commun., 2004. Facilities shaded in gray are no longer in service.]

\begin{tabular}{|c|c|c|c|c|c|c|c|c|}
\hline \multirow{2}{*}{$\begin{array}{l}\text { WWTF } \\
\text { number } \\
\text { (fig. 9) }\end{array}$} & \multirow{2}{*}{ Facility } & \multirow{2}{*}{ Receiving stream } & \multicolumn{2}{|c|}{ Design discharge } & \multicolumn{2}{|c|}{$\begin{array}{c}\text { Ammonia concentration } \\
\text { design limit } \\
\text { (milligrams per liter) }\end{array}$} & \multicolumn{2}{|c|}{$\begin{array}{l}\text { Ammonia load design limit } \\
\text { (kilograms per day) }\end{array}$} \\
\hline & & & $\begin{array}{l}\text { (million } \\
\text { gallons } \\
\text { per day) }\end{array}$ & $\begin{array}{l}\text { (cubic feet } \\
\text { per } \\
\text { second) }\end{array}$ & Summer & Winter & Summer & Winter \\
\hline 1 & Blue T.S. sewer district \#1 & Kansas River & 0.2 & 0.309 & ${ }^{1} 3.0$ & ${ }^{1} 10$ & 0 & ${ }^{2} 0$ \\
\hline 2 & Wamego & Kansas River & .75 & 1.16 & ${ }^{1} 3.0$ & ${ }^{1} 10$ & 2.84 & ${ }^{2} 7.09$ \\
\hline 3 & Saint Marys wastewater-treatment facility & Doyle Creek & .50 & .774 & 2.4 & 8.9 & 5.10 & 5.10 \\
\hline 4 & Rossville & Cross Creek & .14 & .217 & ${ }^{1} 1.5$ & $1_{3.0}$ & .530 & 21.32 \\
\hline 5 & Silver Lake & Ensign Creek & .20 & .305 & ${ }^{1} 1.5$ & ${ }^{1} 3.0$ & .745 & ${ }^{2} 1.86$ \\
\hline 6 & Goodyear Tire & Soldier Creek & 1.4 & 2.24 & & & 0 & ${ }^{2} 0$ \\
\hline 7 & North Topeka & Kansas River & 12 & 18.6 & 5.5 & 12 & 90.8 & 90.8 \\
\hline 8 & Topeka Oakland & Kansas River & 16 & 24.8 & 1.6 & 7.8 & 847 & 847 \\
\hline 9 & Soldier & Soldier Creek & .02 & .029 & ${ }^{1} 1.5$ & ${ }^{1} 3.0$ & .072 & ${ }^{2} .180$ \\
\hline 10 & Sherwood & Shunganunga Creek & 2.4 & 3.71 & 1.9 & 6.5 & 14.5 & 14.5 \\
\hline 11 & Shawnee County sewer district \#33 & Stinson Creek & .22 & .340 & 1.0 & 2.5 & .832 & ${ }^{2} 2.08$ \\
\hline 12 & Shawnee County sewer district \#8 & Stinson Creek (Shunga) & .06 & .093 & 25 & 25 & 5.67 & 5.67 \\
\hline 13 & USD 450 & Whetstone Creek & .03 & .046 & ${ }^{1} 3$ & ${ }^{1} 10$ & .113 & ${ }^{2} .284$ \\
\hline 14 & Perry wastewater-treatment facility & Delaware River & .11 & .170 & ${ }^{1} 1.5$ & ${ }^{1} 3.0$ & .548 & ${ }^{2} 1.37$ \\
\hline 15 & Lecompton wastewater-treatment facility & Kansas River & .07 & .102 & ${ }^{1} 1.5$ & $1_{3.0}$ & .249 & ${ }^{2} .624$ \\
\hline 16 & Lawrence wastewater-treatment facility & Kansas River & 12.5 & 19.3 & 7.0 & 7.0 & 331 & 331 \\
\hline 17 & Farmland Lawrence & Kansas River & .95 & 1.47 & 50 & 50 & 180 & 180 \\
\hline 20 & Turnpike service center & Ninemile Creek & .02 & .028 & ${ }^{1} 1.5$ & ${ }^{1} 3.0$ & .068 & ${ }^{2} .170$ \\
\hline
\end{tabular}


Appendix 2. List of wastewater-treatment facilities (WWTFs) that discharge effluent to the Kansas River and its tributary streams in northeast Kansas and design limits.-Continued

[Source: M.E. Gerard, Kansas Department of Health and Environment, written commun., 2004. Facilities shaded in gray are no longer in service.]

\begin{tabular}{|c|c|c|c|c|c|c|c|c|}
\hline \multirow{2}{*}{$\begin{array}{l}\text { WWTF } \\
\text { number } \\
\text { (fig. 9) }\end{array}$} & \multirow{2}{*}{ Facility } & \multirow{2}{*}{ Receiving stream } & \multicolumn{2}{|c|}{ Design discharge } & \multicolumn{2}{|c|}{$\begin{array}{l}\text { Ammonia concentration } \\
\text { design limit } \\
\text { (milligrams per liter) }\end{array}$} & \multicolumn{2}{|c|}{$\begin{array}{l}\text { Ammonia load design limit } \\
\text { (kilograms per day) }\end{array}$} \\
\hline & & & $\begin{array}{l}\text { (million } \\
\text { gallons } \\
\text { per day) }\end{array}$ & $\begin{array}{l}\text { (cubic feet } \\
\text { per } \\
\text { second) }\end{array}$ & Summer & Winter & Summer & Winter \\
\hline 21 & Linwood wastewater-treatment facility & Ninemile Creek & 0.04 & 0.062 & ${ }^{1} 1.5$ & 13.0 & 0.151 & ${ }^{2} 0.378$ \\
\hline 22 & Tonganoxie wastewater-treatment facility & Tonganoxie Creek & .75 & 1.16 & 2.1 & 7.2 & 4.24 & 5.30 \\
\hline 23 & Leavenworth sewer district \#5 & Hog Creek & .03 & .046 & ${ }^{1} 1.5$ & ${ }^{1} 3.0$ & .113 & ${ }^{2} .284$ \\
\hline 24 & Kansas Waste Water Treatment Inc. & Kansas River & .12 & .186 & 25 & 25 & 11.3 & 11.3 \\
\hline 25 & Gardner wastewater-treatment facility & Kansas River & 2.5 & 3.87 & 1.6 & 1.6 & 15.1 & 15.1 \\
\hline 27 & DeSoto wastewater-treatment facility & Kill Creek & .40 & .619 & 3.1 & 3.1 & 37.8 & 37.8 \\
\hline 28 & Sunflower Army Ammunition Plant & Kansas River & 1.3 & 1.95 & 2.4 & 2.85 & 11.4 & 13.6 \\
\hline 29 & Olathe Cedar Creek & Cedar Creek & 3.0 & 4.64 & 1.6 & 4.1 & 10.6 & 12.1 \\
\hline 30 & Leavenworth sewer district \#2 & Kansas River & .07 & .111 & ${ }^{1} 1.5$ & $1_{3.0}$ & .272 & ${ }^{2} .681$ \\
\hline 31 & Bonner Springs & Kansas River & 1.4 & 2.17 & $1_{3.0}$ & ${ }^{1} 10$ & 5.30 & ${ }^{2} 13.2$ \\
\hline 32 & Olathe Main & Mill Creek & 3.2 & 4.95 & 1.5 & 5.4 & 16.9 & 19.4 \\
\hline 33 & Johnson County Mill Creek Regional & Kansas River & 18.75 & 29.0 & 36 & 15 & 613 & 613 \\
\hline 34 & Kansas City \#20 & Kansas River & 7.0 & 10.8 & 19 & 24 & 410 & 503 \\
\hline 35 & Kansas City \#14 & Kansas River & .12 & .186 & $1_{3.0}$ & ${ }^{1} 10$ & 11.3 & 11.3 \\
\hline 36 & Americold & Kansas River & .003 & .005 & 5.0 & 5.0 & .001 & .001 \\
\hline
\end{tabular}

${ }^{2}$ No permit limits. 


\section{Appendix 3. Hypothetical Simulations Using 30-Day, 10-Year, Low-Flow Conditions}

KDHE requested that the calibrated Kansas River waterquality model be used to describe and evaluate the calibrated model and the same four hypothetical conditions listed in table 12, with one change; reduce the streamflow at Topeka (site 12) to the 30-day, 10-year low flow (30Q10) defined by $\mathrm{KDHE}$ as $670 \mathrm{ft}^{3} / \mathrm{s}$. The effects of changing the streamflow boundary conditions (reducing the streamflow in the Kansas River by one-half) in this manner without adjusting the waterquality boundary conditions for the Kansas River are unknown. Without measuring the water quality of the Kansas River during this low-flow condition, it is impossible to know if the assumed water-quality boundary conditions used in the calibrated model are reasonable enough estimates for the 30Q10 hypothetical simulations to be accurate. For these reasons, conclusions drawn on the basis of the 30Q10 simulations should be considered as having more uncertainty about them than the previous four hypothetical simulations.

The effluent of an additional proposed WWTF and hypothetical alterations to existing WWTF effluent discharges in combination with the existing calibrated model were used to determine the possible effects on water quality in the Kansas River at 30Q10 streamflow $\left(670 \mathrm{ft}^{3} / \mathrm{s}\right.$ at Topeka). All of the hypothetical results were compared to the calibrated model results using 30Q10 streamflow (30Q10 calibrated results). Hypothetical simulations were made using boundary conditions from the winter and summer calibrated models with the exceptions of streamflow at Topeka and concentrations of ammonia, nitrite plus nitrate, total phosphorus, orthophosphorus, and carbonaceous biochemical oxygen demand (table 12). All simulated results were cross-sectional averages for noon and midnight on February 27, 2002, and July 31, 2002.

\section{Effects of 30010 Hypothetical Simulation 1}

First, the 30Q10 calibrated model was altered so that the effluent discharges from three major main-stem WWTFs were equal to their design flow and current (2005) permitted limit for ammonia (table 12). In comparison to the $30 \mathrm{Q} 10$ calibrated results, simulated in-stream ammonia concentrations were usually larger in 30Q10 hypothetical simulation 1 in the winter and summer (fig. 34A and $B$ ). Nearly all of the 30Q10 simulated instream ammonia values from the Johnson County Mill Creek Regional treatment facility (river mile 15) to the Missouri River exceeded the Kansas chronic aquatic-life criterion for early-life stages of fish present. The 30Q10 hypothetical simulation 1 results were plotted with the results from the other three $30 \mathrm{Q} 10$ hypothetical simulations for further comparison (figs. 34-36).

\section{Effects of 30010 Hypothetical Simulation 2}

The change for $30 \mathrm{Q} 10$ hypothetical simulation 2 was to discharge effluent from a proposed new WWTF that would serve the growing population of Johnson County, Kansas. The design flow for this proposed WWTF was $85 \mathrm{ft}^{3} / \mathrm{s}$ (55 Mgal/d), more than two times larger than any of the existing WWTF design flows. The simulation was run for winter and summer conditions in two parts: (1) locating the proposed WWTF upstream from DeSoto (river mile 31), and (2) locating the proposed WWTF downstream from Cedar Creek (river mile 25). The two parts of the simulation were necessary to help determine the effects of the proposed WWTF's effluent on the horizontal source-water wells located along the Kansas River near the confluence of Cedar Creek. These wells provide drinking water for the city of Olathe.

Results of 30Q10 hypothetical simulation 2, where the addition of the proposed WWTF was upstream from DeSoto or downstream from Cedar Creek, indicated similar increases in ammonia downstream from the proposed WWTF. In the winter, ammonia concentrations downstream from the proposed WWTF indicated similar characteristics but at different locations depending on the WWTF hypothetical location (fig. 34A). Results indicated a steady increase in ammonia concentrations in the Kansas River to about $0.1 \mathrm{mg} / \mathrm{L}$ greater than the calibrated results within about $2.5 \mathrm{mi}$ downstream from both hypothetical locations for the proposed WWTF. Several of the simulated in-stream values exceeded the Kansas chronic aquaticlife criterion for early-life stages of fish present. Water temperatures less than $5^{\circ} \mathrm{C}$ minimized nitrification and had little effect on dissolved-oxygen concentrations (fig. 34C). None of simulated dissolved-oxygen concentrations in the winter were less than the Kansas aquatic-life criterion $(5.0 \mathrm{mg} / \mathrm{L})$.

Summer 30Q10 simulations indicated that ammonia concentrations increased substantially for about $5 \mathrm{mi}$ downstream from the proposed WWTF and then maintained a steady concentration slightly greater than the concentrations for $30 \mathrm{Q} 10$ calibrated results (fig. 34B). The maximum 30Q10 simulated main-stem values for both proposed WWTF locations were equal to or exceeded the Kansas chronic aquatic-life criterion for early-life stages of fish present. As a result of the increased ammonia concentrations, main-stem nitrification suppressed dissolved-oxygen concentrations to less than the Kansas aquatic-life criterion $(5.0 \mathrm{mg} / \mathrm{L})$ for 1 to $2 \mathrm{mi}$ downstream from the proposed WWTF (fig. 34D).

\section{Effects of 30010 Hypothetical Simulation 3}

For 30Q10 hypothetical simulation 3, adjustments were made to three major WWTFs (Topeka Oakland, Lawrence, and Johnson County Mill Creek) current design flows and permitted limits for ammonia (Appendix 2). In most cases, this meant that the magnitude of the effluent flow was increased and the concentration of ammonia was decreased from the WWTF values measured and used in the 30Q10 calibrated model. 
A. Simulated ammonia concentrations, winter conditions at $30 Q 10$ streamflow

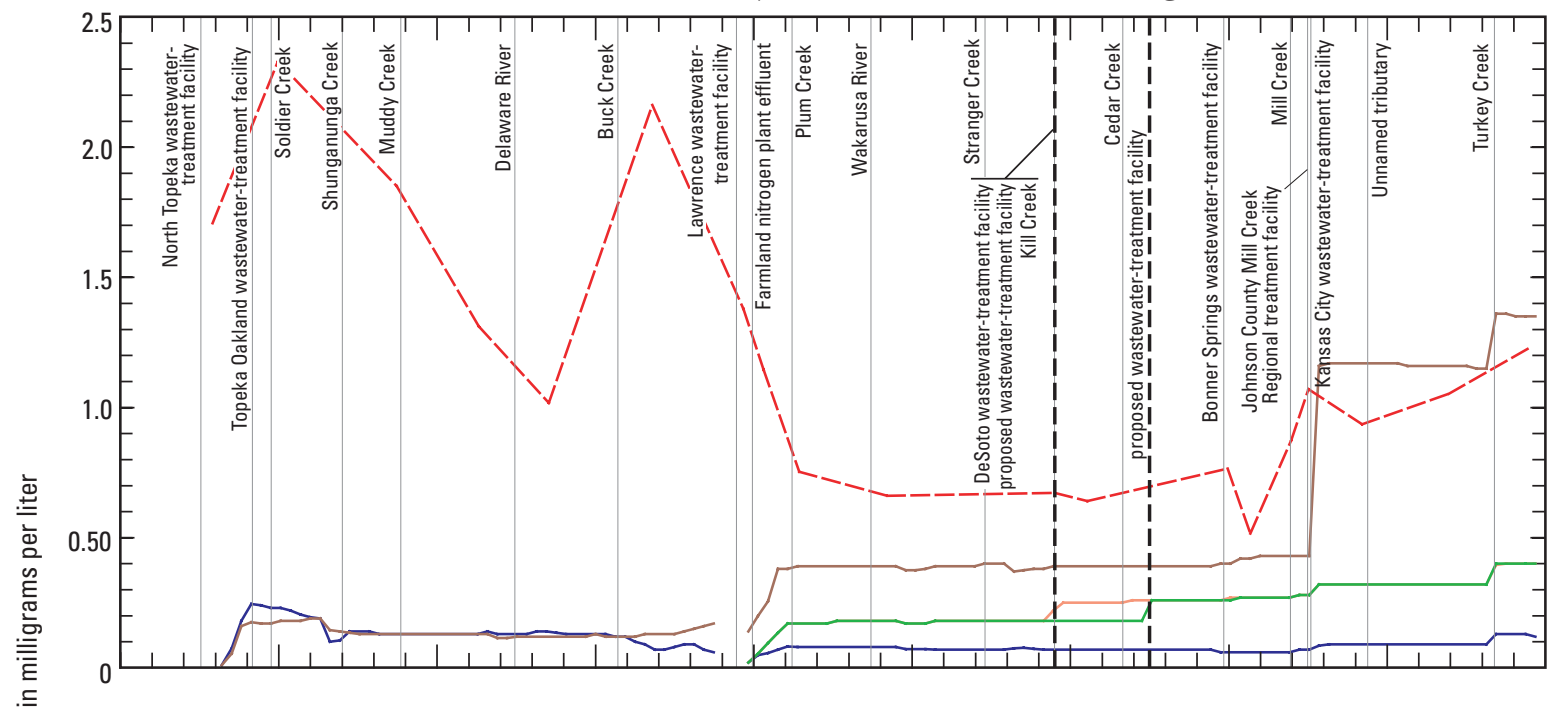

B. Simulated ammonia concentrations, summer conditions at $30 Q 10$ streamflow

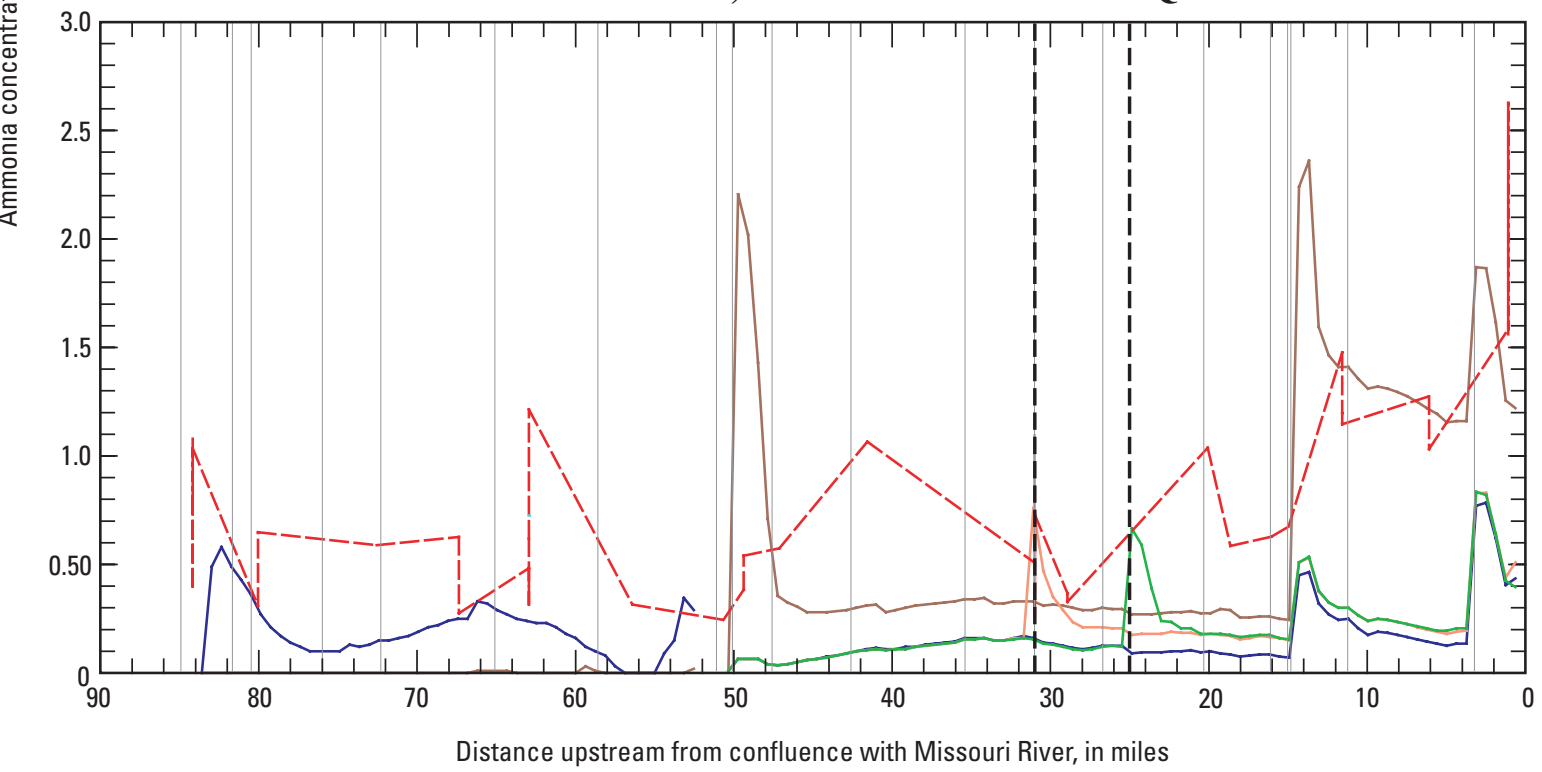

EXPLANATION

- Simulated ammonia concentrations for 30Q10 calibrated model

- Ammonia concentrations for 30Q10 hypothetical simulation 1

- Ammonia concentrations for 30Q10 hypothetical simulation 2 , with proposed treatment facility upstream from Cedar Creek
- Ammonia concentrations for 30Q10 hypothetical simulation 2, with proposed treatment facility downstream from Cedar Creek

-- Chronic aquatic-life criterion with early-life stages of fish present (Kansas Department of Health and Environment, 2002)

Figure 34. Simulated ammonia and dissolved-oxygen concentrations in Kansas River from Topeka to Kansas City during winter and summer 30-day, 10-year, low-flow (30010) conditions for 30010 calibrated model and hypothetical simulations 1 and 2 . 
C. Simulated dissolved-oxygen concentrations, winter conditions at $30 Q 10$ streamflow

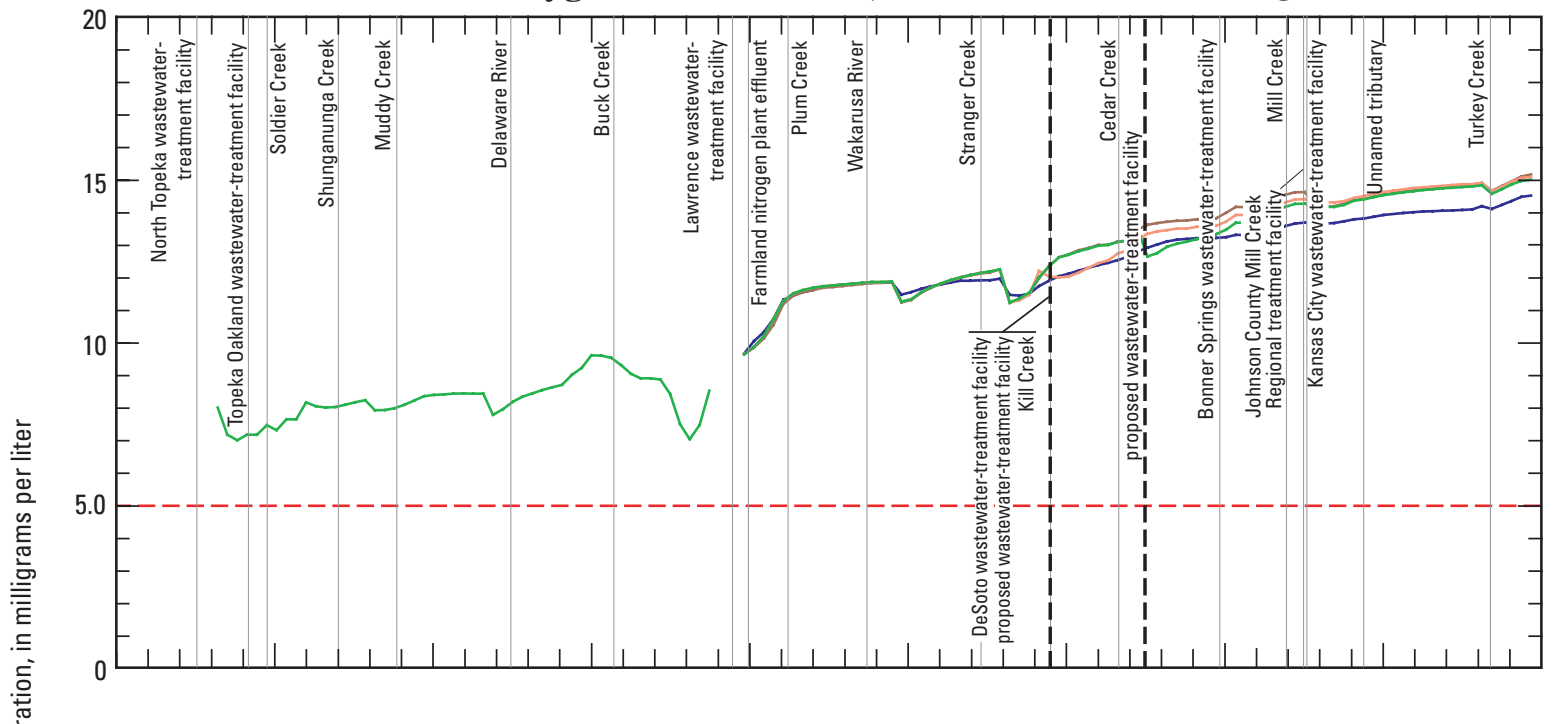

D. Simulated dissolved-oxygen concentrations, summer conditions at $30 Q 10$ streamflow

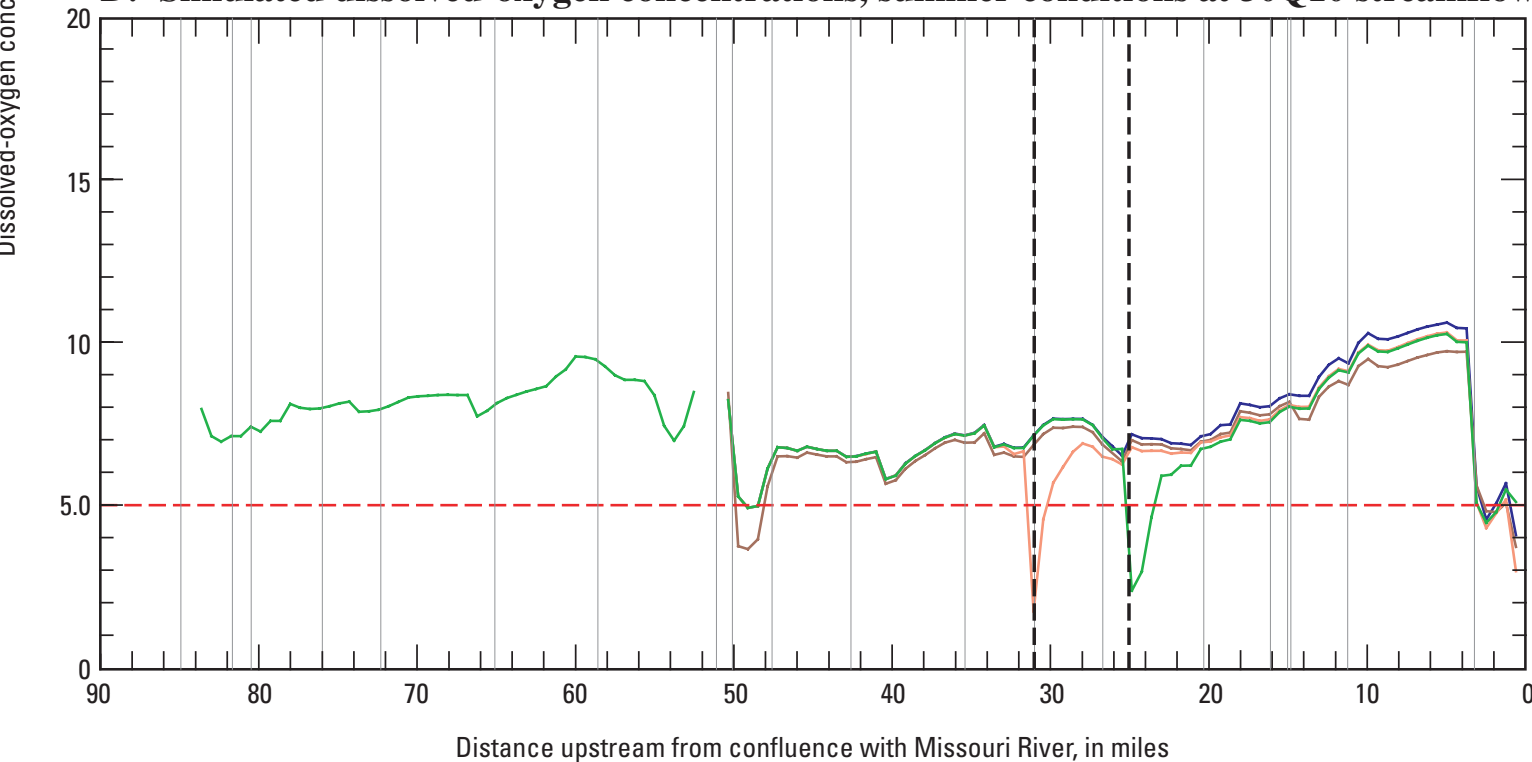

EXPLANATION

- Simulated dissolved-oxygen concentrations for 30Q10 calibrated model

- Dissolved-oxygen concentrations for 30Q10 hypothetical simulation 1

- Dissolved-oxygen concentrations for 30Q10 hypothetical simulation 2 , with proposed treatment facility upstream from Cedar Creek
— Dissolved-oxygen concentrations for 30Q10 hypothetical simulation 2 , with proposed treatment facility downstream from Cedar Creek

-- Chronic aquatic-life criterion with early-life stages of fish present (Kansas Department of Health and Environment, 2002)

Figure 34. Simulated ammonia and dissolved-oxygen concentrations in Kansas River from Topeka to Kansas City during winter and summer 30-day, 10-year, low-flow (30010) conditions for 30010 calibrated model and hypothetical simulations 1 and 2.-Continued 
Results for 30Q10 hypothetical simulation 3 indicated that ammonia concentrations gradually increased from upstream to downstream along the Kansas River during winter and summer. Ammonia concentrations ranged from 0.01 to $0.3 \mathrm{mg} / \mathrm{L}$ in the winter and from 0.03 to $0.6 \mathrm{mg} / \mathrm{L}$ during the summer (figs. $35 \mathrm{~A}$ and $35 B$ ). In-stream ammonia concentrations incrementally increased downstream from each major WWTF. Ammonia concentration increased the most downstream from the Turkey Creek confluence (river mile 3.2). Nelson WWTF discharges into Turkey Creek just upstream from the confluence. The ammonia concentration of Turkey Creek (site 49, fig. 2) just downstream from the Nelson WWTF effluent (site 37, fig. 9) was not changed from the concentration used in the calibrated model and was the largest ammonia concentration of all the WWTF effluents for hypothetical simulation 3. 30Q10 hypothetical simulation 3 did not simulate main-stem ammonia concentrations that were larger than the Kansas chronic aquatic-life criterion for early-life stages of fish present.

Concentrations of dissolved oxygen for the 30Q10 hypothetical simulation 3 were similar to the dissolved-oxygen concentrations reported from the original calibrated model during both winter and summer (fig. 35C and 35D). Only simulated main-stem dissolved-oxygen concentrations near Lawrence (river mile 51) and Turkey Creek (river mile 3.2) were less than the Kansas aquatic-life criterion $(5.0 \mathrm{mg} / \mathrm{L})$.

\section{Effects of 30010 Hypothetical Simulation 4}

Adjustments to the calibrated model for 30Q10 hypothetical simulation 4 were a combination of adjustments from 30Q10 hypothetical simulations 1 and 2. Effluent from a proposed new WWTF was added to discharge in the Kansas River just downstream from the Cedar Creek confluence (river mile 25), and the design flows and ammonia concentrations for three major WWTFs (Topeka Oakland, Lawrence, Johnson County Mill Creek) were adjusted to the same values as in 30Q10 hypothetical simulation 2. All values for the other
WWTFs were the same as the values used for the 30Q10 calibrated model.

Simulated results for 30Q10 hypothetical simulation 4 indicated main-stem concentrations of ammonia similar to those simulated for hypothetical simulation 3, with the exception of the concentrations downstream from the proposed WWTF (fig. $36 A$ and $36 B$ ). In the summer, the simulated results indicated that the proposed WWTF would have a profound effect on ammonia and dissolved-oxygen concentration for about $3 \mathrm{mi}$ downstream from its hypothetical location (fig. $36 B$ and $36 D$ ). Ammonia concentrations remained slightly larger than the concentrations in 30Q10 hypothetical simulation 2 until about river mile 10, where they were approximately equal. Main-stem ammonia concentrations were equal to or less than those simulated with the calibrated model except near the Lawrence (river mile 51) and proposed WWTFs. Summer simulated ammonia concentrations near the proposed WWTF were greater than the Kansas chronic aquatic-life-support criterion for early-life stages of fish present.

Concentrations of dissolved oxygen for 30Q10 hypothetical simulation 4 were similar to the dissolved-oxygen concentrations reported from the $30 \mathrm{Q} 10$ calibrated model during both winter and summer with some exceptions (fig. $36 C$ and $36 D$ ). During the winter, downstream from the proposed new WWTF (river mile 25), simulated dissolved-oxygen concentrations decreased slightly (about $0.5 \mathrm{mg} / \mathrm{L}$ ) and gradually increased over the next $5 \mathrm{mi}$ to levels identical to the calibrated model. During the summer, simulated dissolved-oxygen concentrations downstream from the Lawrence WWTF (river mile 50) decreased to $4.0 \mathrm{mg} / \mathrm{L}$ before increasing gradually over the next 3 mi to concentrations similar to the calibrated model. Also, simulated dissolved-oxygen concentrations downstream from the hypothetical WWTF (river mile 25) decreased to concentrations that were less than the Kansas aquatic-life criterion $(5.0 \mathrm{mg} / \mathrm{L})$, reaching a minimum of about $2 \mathrm{mg} / \mathrm{L}$ before increasing over the next $4 \mathrm{mi}$ to levels similar to the calibrated model. 
A. Simulated ammonia concentrations, winter conditions at $30 Q 10$ streamflow

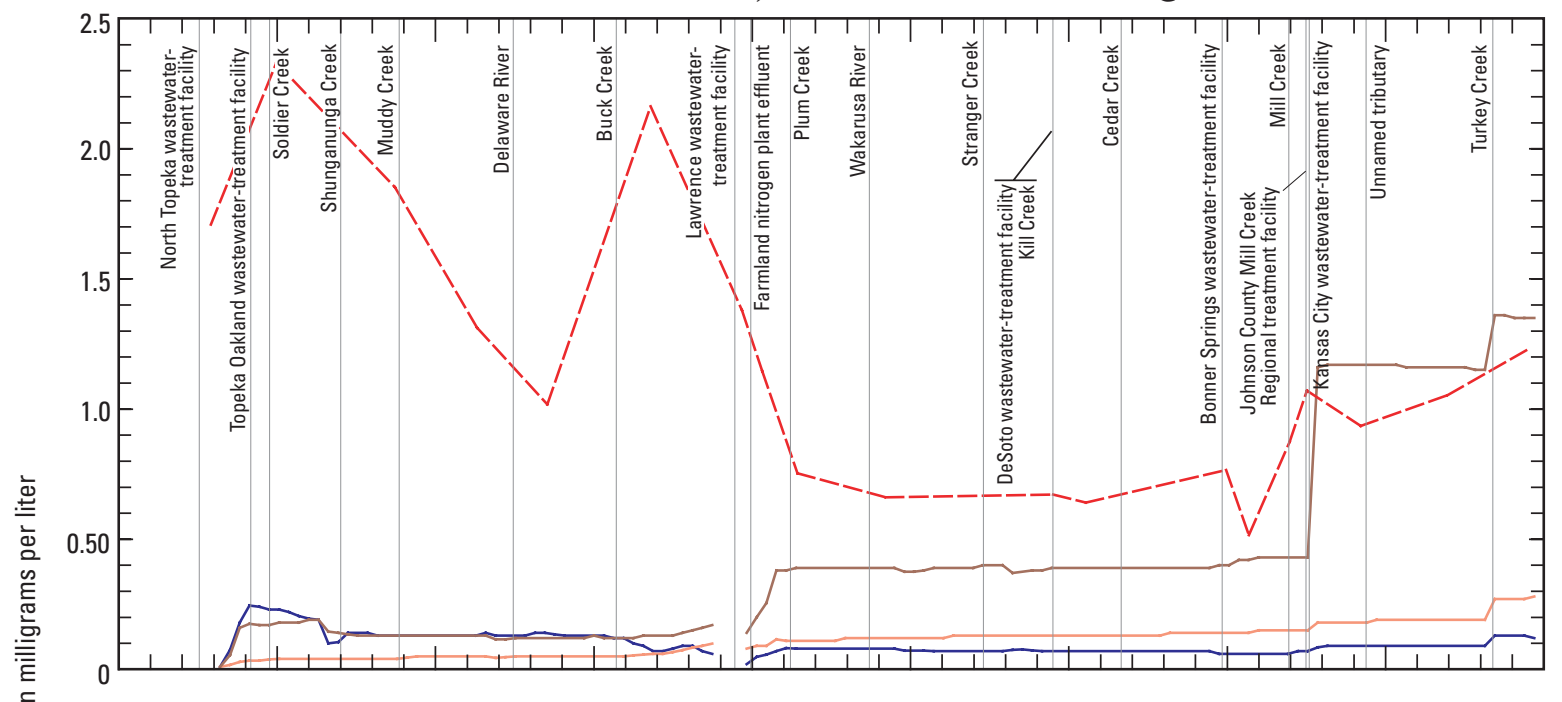

\section{B. Simulated ammonia concentrations, summer conditions at $30 Q 10$ streamflow}

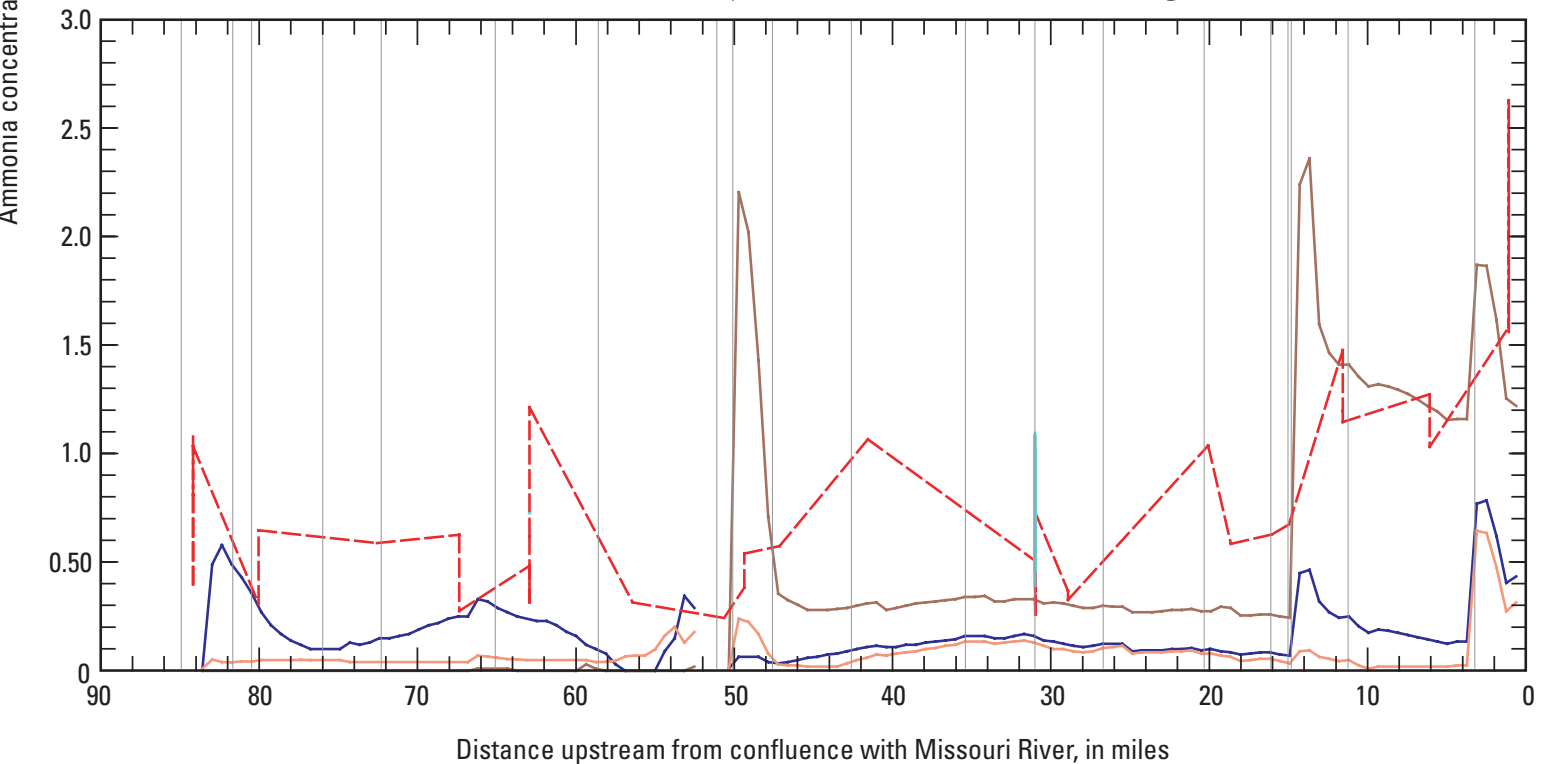

\section{EXPLANATION}

- Simulated ammonia concentrations for 30 Q10 calibrated model

- Ammonia concentrations for 30Q10 hypothetical simulation 1
- Ammonia concentrations for 30Q10 hypothetical simulation 3

-- Chronic aquatic-life criterion with early-life stages of fish present (Kansas Department of Health and Environment, 2002)

Figure 35. Simulated ammonia and dissolved-oxygen concentrations in Kansas River from Topeka to Kansas City during winter and summer 30-day, 10-year, low-flow (30010) conditions for 30010 calibrated model and hypothetical simulations 1 and 3 . 
C. Simulated dissolved-oxygen concentrations, winter conditions at $30 Q 10$ streamflow

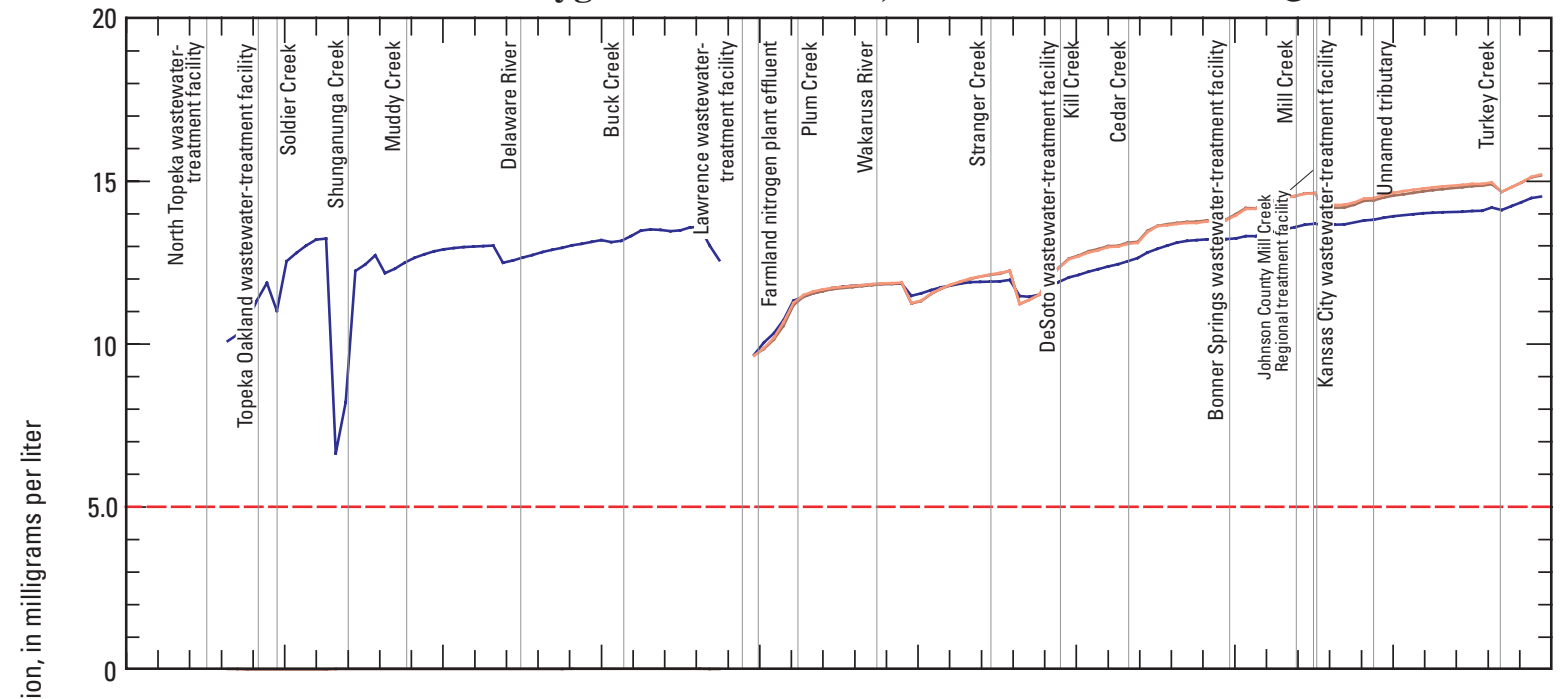

D. Simulated dissolved-oxygen concentrations, summer conditions at $30 Q 10$ streamflow

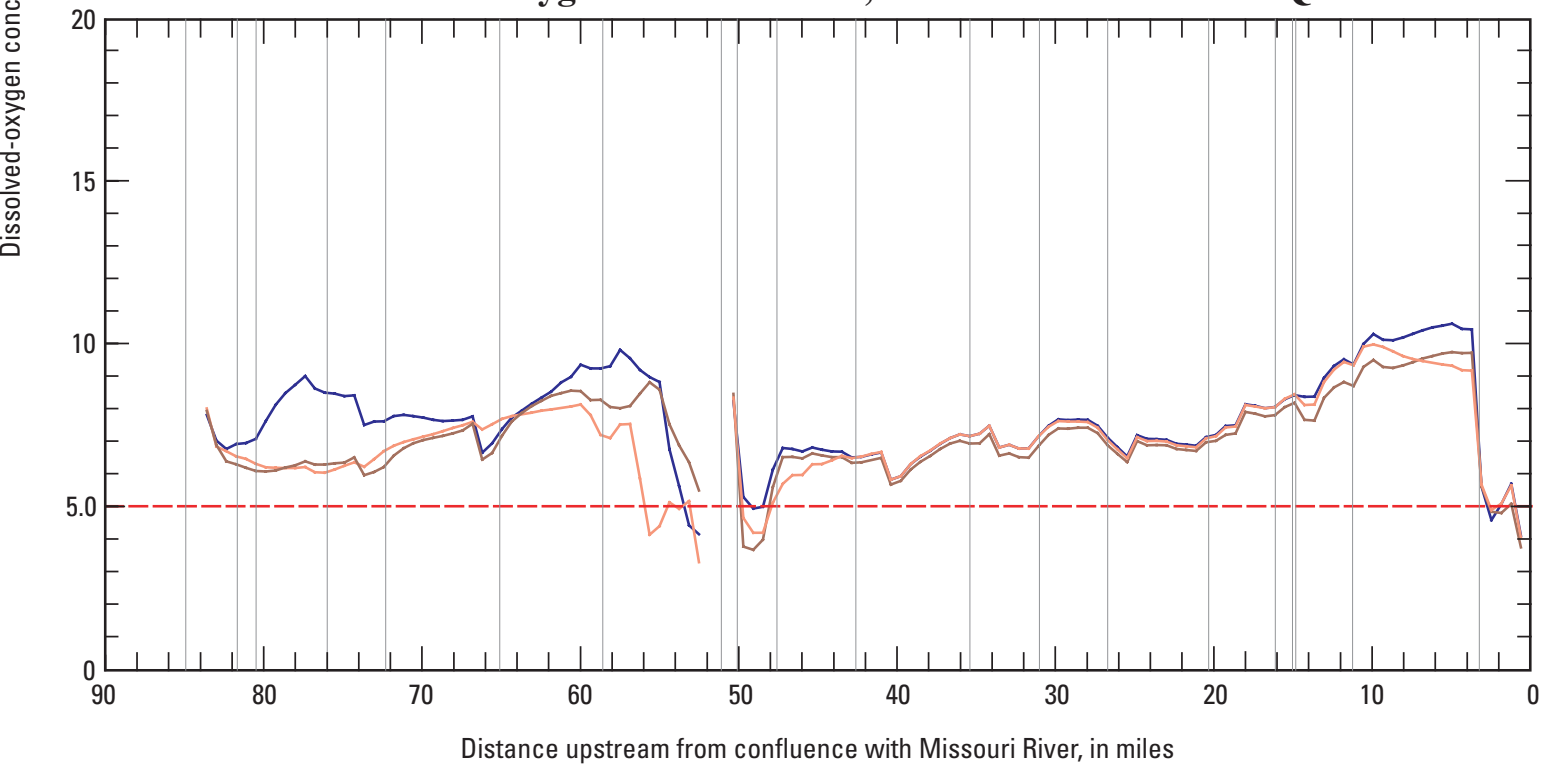

EXPLANATION

- Simulated dissolved-oxygen concentrations for 30Q10 calibrated model

- Dissolved-oxygen concentrations for 30Q10 hypothetical simulation 1
- Dissolved-oxygen concentrations for 30Q10 hypothetical simulation 3

- - Chronic aquatic-life criterion with early-life stages of fish present (Kansas Department of Health and Environment, 2002)

Figure 35. Simulated ammonia and dissolved-oxygen concentrations in Kansas River from Topeka to Kansas City during winter and summer 30-day, 10-year, low-flow (30010) conditions for 30010 calibrated model and hypothetical simulations 1 and 3.-Continued 
A. Simulated ammonia concentrations, winter conditions at 30Q10 streamflow

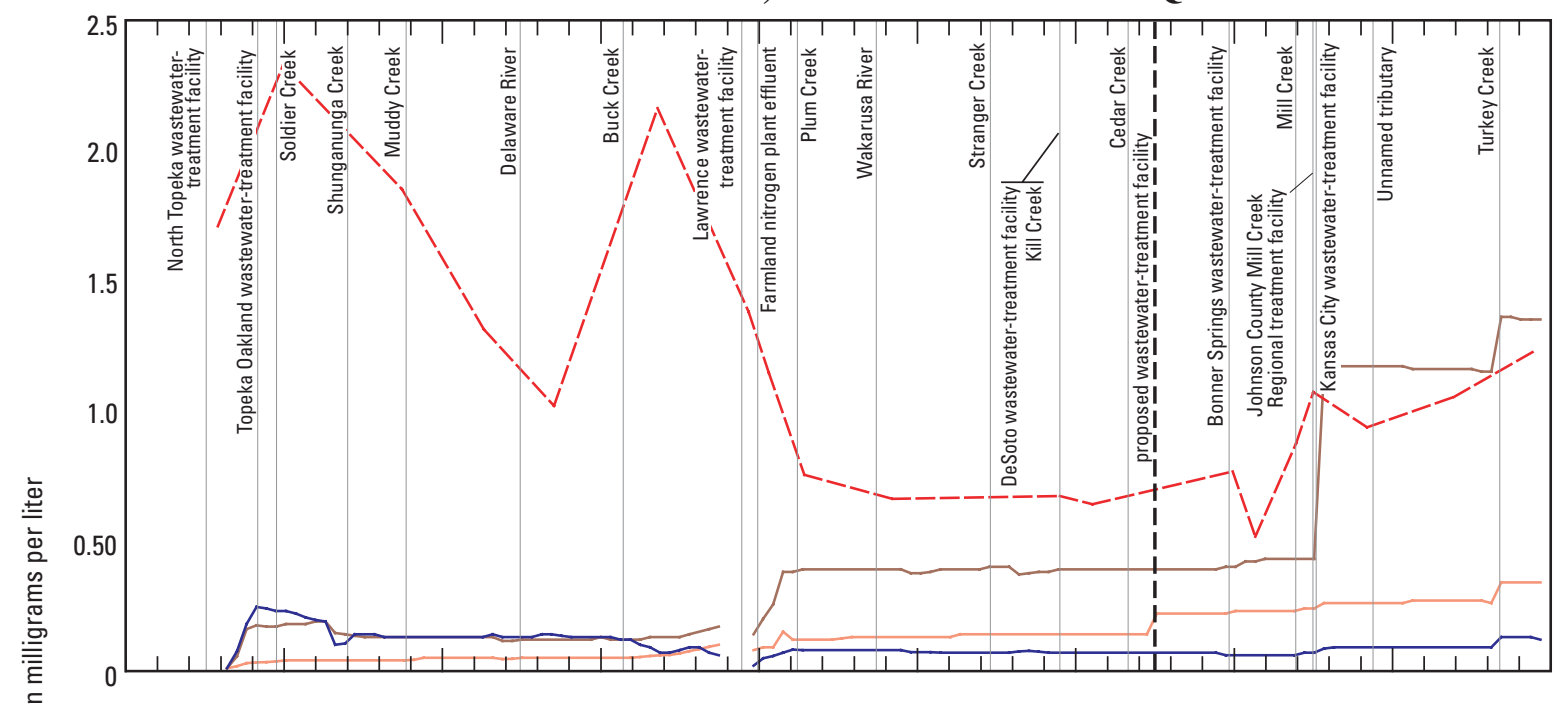

B. Simulated ammonia concentrations, summer conditions at $30 Q 10$ streamflow

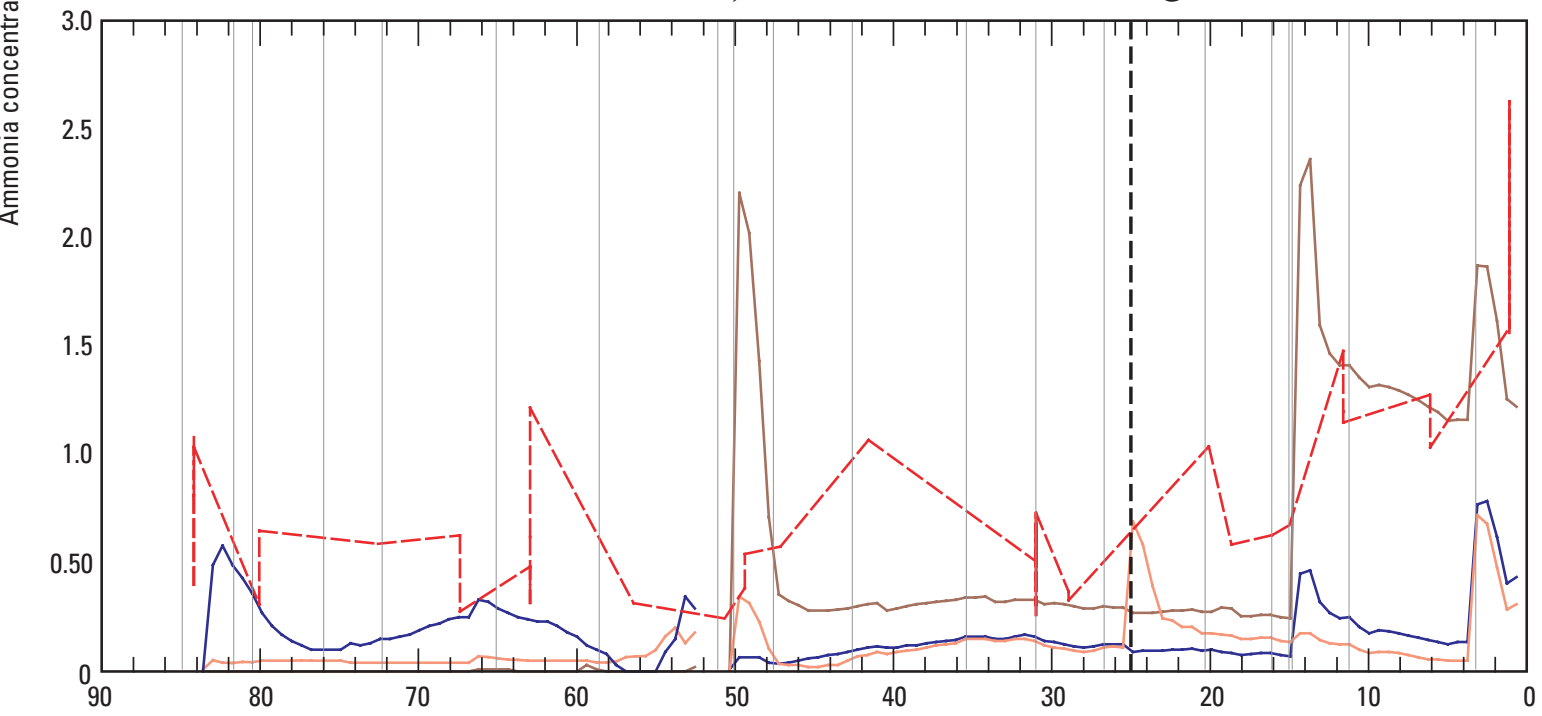

Distance upstream from confluence with Missouri River, in miles

\section{EXPLANATION}

- Simulated ammonia concentrations for 30Q10 calibrated model

- Ammonia concentrations for 30Q10 hypothetical simulation 1
- Ammonia concentrations for 30Q10 hypothetical simulation 4 , with proposed treatment facility downstream from Cedar Creek (river mile 25)

-- Chronic aquatic-life criterion with early-life stages of fish present (Kansas Department of Health and Environment, 2002)

Figure 36. Simulated ammonia and dissolved-oxygen concentrations in Kansas River from Topeka to Kansas City during winter and summer 30-day, 10-year, low-flow (30010) conditions for 30010 calibrated model and hypothetical simulations 1 and 4. 


\section{Simulated dissolved-oxygen concentrations, winter conditions at $30 Q 10$ streamflow}

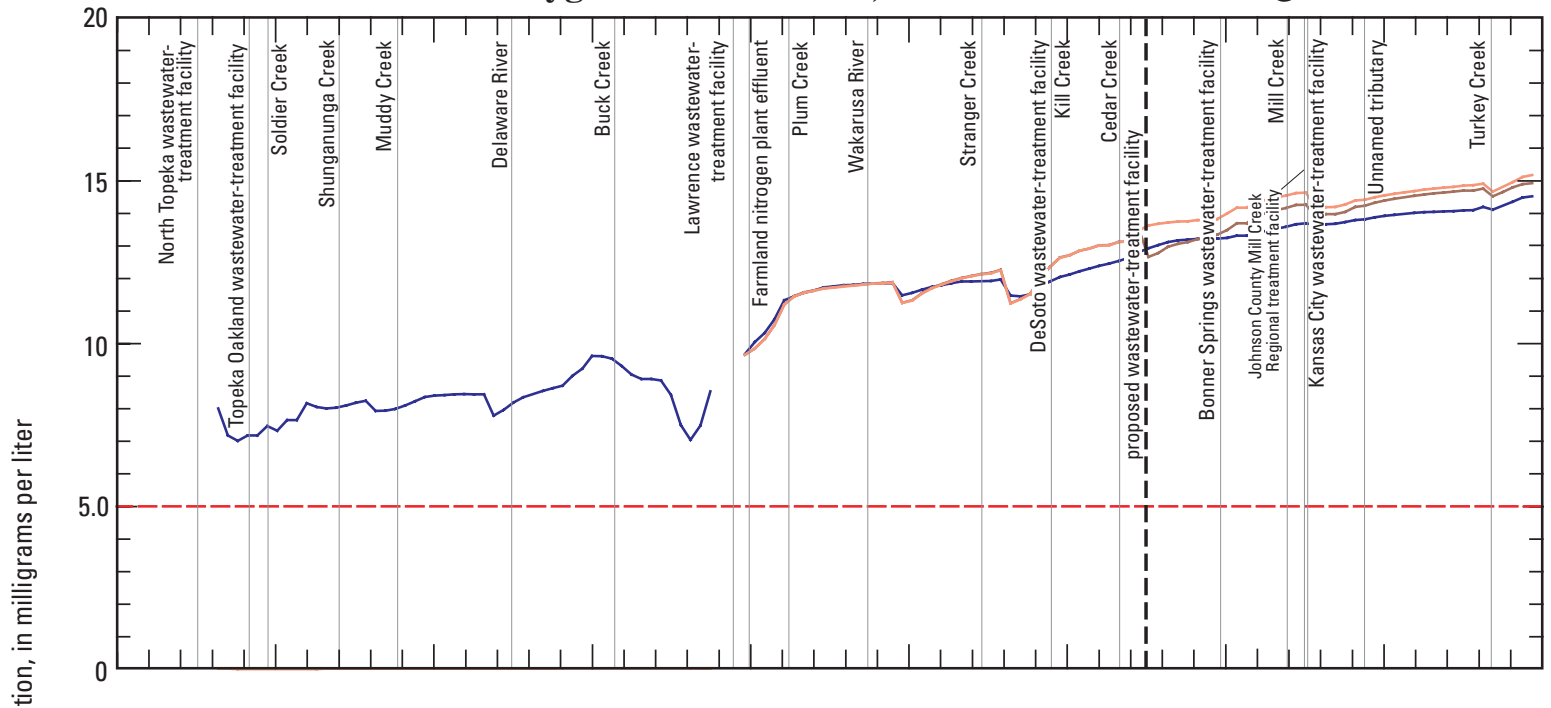

$D$. Simulated dissolved-oxygen concentrations, summer conditions at 30Q10 streamflow

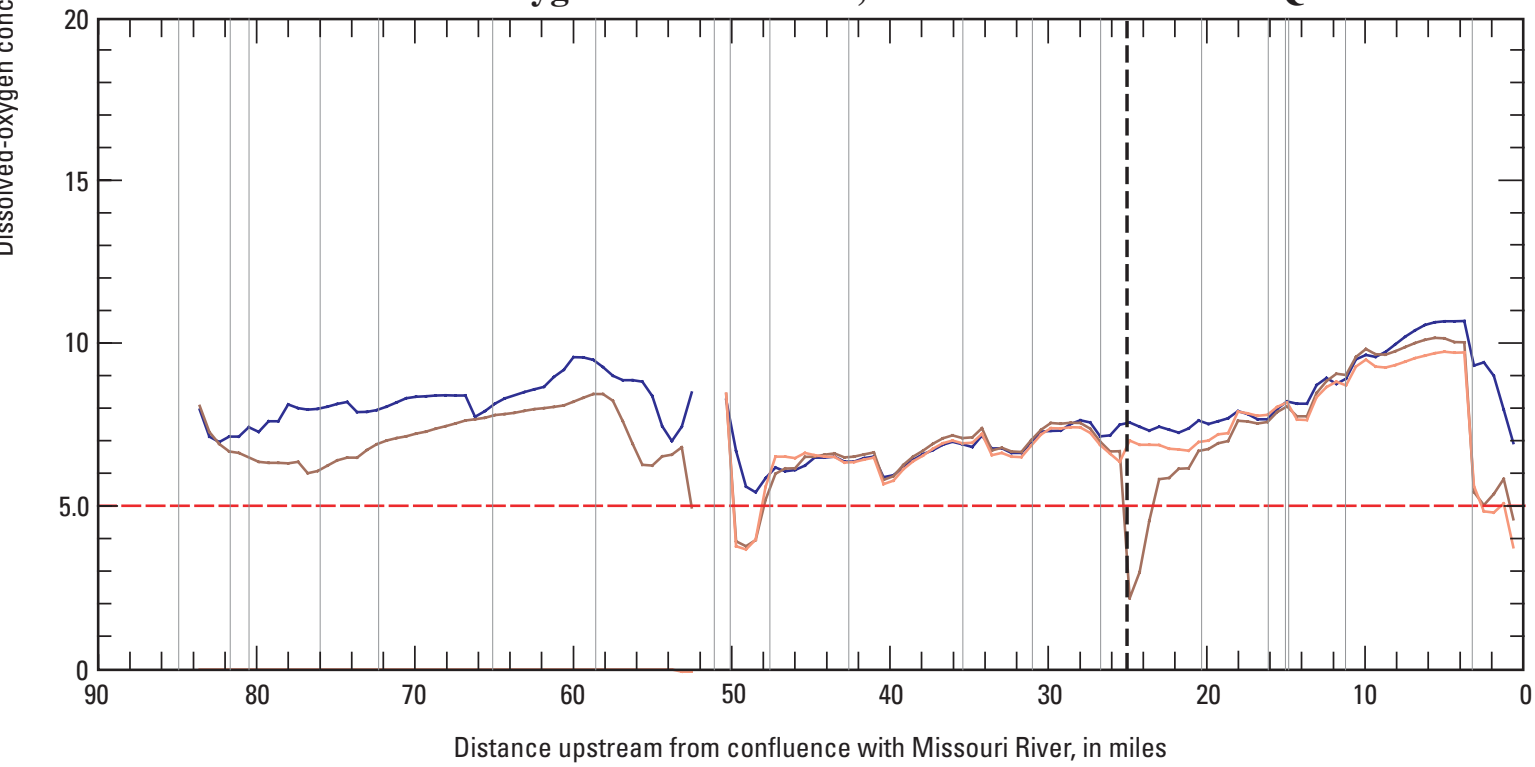

\section{EXPLANATION}

- Simulated dissolved-oxygen concentrations for 30Q10 calibrated model

— Dissolved-oxygen concentrations for 30Q10 hypothetical simulation 1
— Dissolved-oxygen concentrations for 30Q10 hypothetical simulation 4 , with proposed treatment facility downstream from Cedar Creek (river mile 25)

- - Chronic aquatic-life criterion with early-life stages of fish present (Kansas Department of Health and Environment, 2002)

Figure 36. Simulated ammonia and dissolved-oxygen concentrations in Kansas River from Topeka to Kansas City during winter and summer 30-day, 10-year, low-flow (30010) conditions for 30010 calibrated model and hypothetical simulations 1 and 4.-Continued 